\title{
BIOETHICAL EDUCATION IN THE LOCAL CHURCH
}

\author{
by \\ Willie E. Honeycutt \\ B.S., Liberty University, 1985 \\ M.Div., Liberty Theological Seminary, 1992
}

\author{
A MAJOR PROJECT \\ Submitted to the faculty \\ in partial fulfillment of the requirements \\ for the degree of \\ DOCTOR OF MINISTRY \\ at Trinity Evangelical Divinity School
}

Deerfield, Illinois

December 2008 
(C) 2008 by Willie E. Honeycutt

All rights reserved 
Accepted:

\section{Project Mentor}

Second Reader

Program Director 


\begin{abstract}
In light of the challenges of new biotechnologies, the church must reassert its commitment to the concept of the sanctity of human life created in the image of God. One way to do this is for the local church to develop a strategy for educating its congregants in bioethics. This educational task begins with an awareness of what bioethics involves, what issues are bioethical in nature, and a demonstration of their urgency.

In chapter one, I propose to introduce the challenge of bioethics facing the church, explain why I am passionate about this topic and introduce some of the works I have discovered in my research that have given me specific direction in shaping this project. I will discuss some of the common objections that I have encountered when disclosing this project with others, enumerate my goals, objectives and the methodology I will use, and explain the scope and limitations of this project.

I have divided chapter two into two parts. Part one lays the theological and biblical groundwork for bioethics education in the local church. I will focus on establishing the importance of worldview, and especially understanding worldview as a metanarrative that forms a moral community. Part two explores how to use these ideas in the context of church community for bioethical discernment. I will defend the importance of community then explain how the church as a community can practice the process of moral discourse, deliberation, discernment and decision in light of its doctrinal convictions.
\end{abstract}


Chapter three explains the methodologies I used to execute the project, and the results I obtained. There were two primary methods; a focused group discussion following a thirteen week elective, and a congregational survey before and after a four-part series of sermons addressing current bioethical issues.

Chapter four entails analysis and discussion of data gleaned from one local congregation's response to and evaluation of these methodologies.

In chapter five, I will share some of the lessons I have learned throughout the process, and on the basis of these lessons, make practical suggestions for future ministry. 
To those who exercised the greatest patience

in making this possible; Holly, my wife,

Heather and Jon 


\section{CONTENTS}

TABLE OF ABBREVIATIONS

ix

Chapter

1. THE NEED FOR BIOETHICAL EDUCATION IN THE LOCAL $\mathrm{CHURCH}$

Biotechnology, Bioethics and the Redefinition of

Humanity

The Challenge of Bioethics to the Church

Answering Objections ................................................................... 6

Project's Relation to the Ministry of the Writer ...................................... 17

Current Literature on Bioethics and the Church .................................... 20

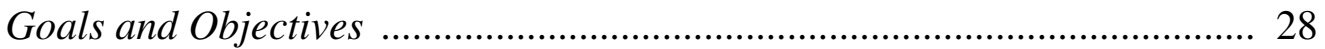

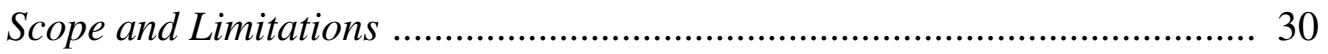

2. THE PROJECT IN BIBLICAL AND THEOLOGICAL

PERSPECTIVE

Part One: Premises for Bioethical Education in the Local Church

The Christian Mind and Worldview ....................................................... 31

Major Motifs in the Biblical Metanarrative .......................................... 37

Part Two: The Practice of Bioethical Education in the Local Church ........................................................................................ 69

Community, Narrative and Ethics .................................................... 70

The Church as Moral Community ...................................................... 81

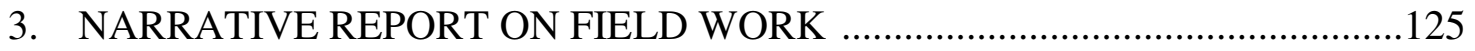

Narrative on Methodology and Project Execution .....................................125

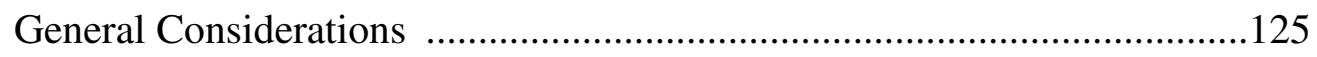

viii 
Specific Applications 126

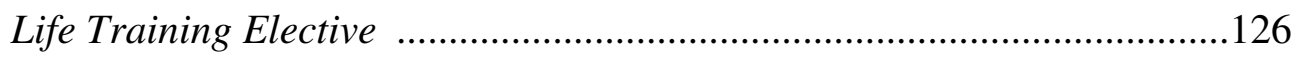

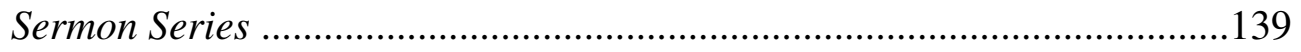

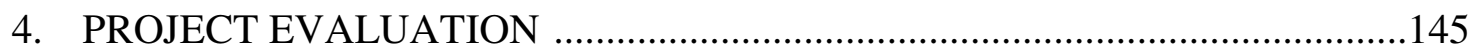

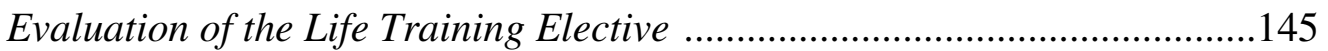

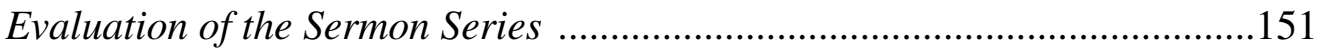

5. LESSONS LEARNED AND RECOMMENDATIONS FOR

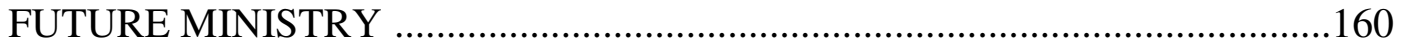

Lessons from the Life Training Elective …………………..........................160

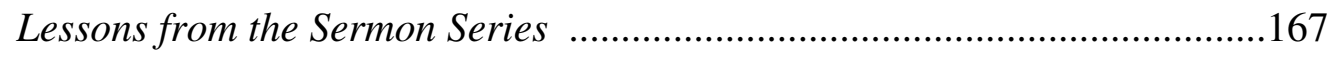

Recommendations for Future Ministry .........................................................169

Appendix

1. INFORMED CONSENT FORM FOR PARTICIPANTS IN FOCUS GROUP ………………………………....................................173

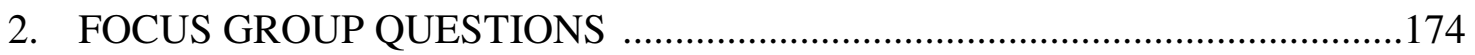

3. FIRST (PRE-SERIES) CONGREGATIONAL SURVEY ……………….........175

4. SECOND (POST-SERIES) CONGREGATIONAL SURVEY ..........................179

5. HANDOUTS FOR THIRTEEN WEEK ELECTIVE ……….............................181

6. FOUR SERMONS ON BIOETHICS AND BIOETHICAL ISSUES .................223

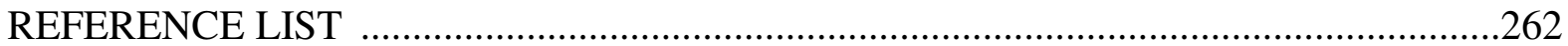




\section{ABBREVIATIONS}

4-D The communal bioethical process which involves Discourse, Deliberation, Discernment and Decision

5-C The framework of the biblical narrative of Creation, Corruption, Covenant, Consummation and Christ which serves as the basis for moral discernment.

AD Advance Directives

CAC Community Action Committee (HBCs committee to inform congregants on social, ethical issues, and provide ways to become involved for change)

G Goals 1, 2, 3 and 4 proposed for this project.

HBC Heritage Baptist Church

HPC Health Care Professional

IVF In-vitro Fertilization

LTE Life Training Elective (13 week adult electives offered Wednesday evenings)

M Message (any one of four sermons preached on January 13 and 20, 2008)

NC New Connections; Our Gateway to Membership (Course workbook for new members class at $\mathrm{HBC}$ )

NMP Non-medical Personnel

PGD Pre-implantation Genetic Diagnosis

S Survey (any one of two surveys given to congregants of HBC during the January 13 a.m. and January 20 p.m. services) 


\section{CHAPTER 1}

\section{THE NEED FOR BIOETHICAL EDUCATION \\ IN THE LOCAL CHURCH}

Emerging biotechnologies confront the church with specific and daunting challenges. These challenges make it incumbent upon local congregations to develop strategies for guiding their congregants with wisdom and discernment as they face them.

\section{Biotechnology, Bioethics and the Redefinition of Humanity}

We are living in the age of biotechnology, which refers, in large part, to all the ways that the knowledge and techniques of biological science are applied to the healing and even enhancing of humans. Bioethics involves reflection on the moral implications of biological research and applications of technology, especially to the field of medicine. In short, bioethics is moral reflection on the uses of biotechnology to determine how it should and should not be applied.

Biotechnology increasingly confronts us with some of the most momentous ethical challenges we have ever faced as humans. This is largely the case because biotech's most important object is humanity itself. Issues involving artificial birth control, assisted reproduction, genetic screening and engineering, embryonic cloning and stem-cell research, abortion, physical and neurological enhancements through cybernetics, nanotechnology, psychotropic medicine, and end-of-life dilemmas are some major bioethical issues looming 
large on the radar of many cultures throughout the world. Through biotech we are looking at a possible future in which human embryos are generated (farmed) in labs solely for experimentation, euthanasia is nearly as commonplace as abortion, parents will have the option to select detailed genetic features of their offspring prior to their conception, and baby-making will not be customarily done in the bed but the lab! Given these growing powers, along with the concomitants of an expanding influence of postmodern thought and increase of ethical relativism, there is cause for alarm and action.

C. S. Lewis argued that once a society abandons the idea of objective truth, it naturally and inevitably follows that morality and then the very notion of human nature will become tenuous. That is, the abolition of objective moral truth gives rise to the abolition of man qua man. Consequently, when the elite few possessing great power in biotech, whom Lewis calls "the Conditioners," have jettisoned traditional moral boundaries, they will not hesitate to refashion the masses according to their own Promethean wish. The redefinition of veracity, Lewis warns, leads to the remaking of morality which opens the door for the wholesale refashioning of humanity (Lewis 1955).

With regard to these and other concerns, pundits warn that we may already be well on our way to this future. "The most significant threat posed by contemporary biotechnology is the possibility that it will alter human nature and thereby move us into a 'post-human' stage of history" (Fukuyama 2002, 7). McKibben likewise warns,

We stand at a threshold: if we aggressively pursue any or all of several technologies now before us, we may alter our relationships not with the rest of nature, but with ourselves. First, human genetic engineering and then advanced forms of robotics and nanotechnology will call into question, often quite explicitly, our understanding of what it means to be a human being. (McKibben 2003, xii) 
Consequently, "It is in bioethics, that point of intersection of the professions, the academy, and public policy, in which the dignity of the human being is constantly open to redefinition" (Cameron, Daniels and White 2000, xii-xiii).

Such redefinition has already begun. For example, Robert Haynes, president of the 16th International Congress of Genetics, once said,

For three thousand years at least, a majority of people have considered that human beings were special ... it's the Judeo-Christian view of man. What the ability to manipulate genes should indicate to people is the very deep extent to which we are biological machines. The traditional view is built on the foundation that life is sacred ... well, not anymore. It's no longer possible to live by the idea that there is something special, unique, even sacred about living organisms. (Haynes 1993)

Professor Peter Singer of Princeton University recently articulated an even more invidious attack against a specifically religious and especially biblical view of human dignity.

During the next 35 years, the traditional view of the sanctity of human life will collapse under pressure from scientific, technological, and demographic developments. By 2040, it may be that only a rump of hard-core, know-nothing religious fundamentalists will defend the view that every human life, from conception to death, is sacrosanct. (Singer 2005)

Awareness of such sentiments no doubt leads bioethicists like Leon Kass to conclude, "Human nature itself lies on the operating table, ready for alteration, for eugenic and neuropsychic 'enhancement,' for wholesale redesign. Anyone who cares about preserving our humanity, the time has come to pay attention" (Kass 2002, 4).

\section{The Challenge of Bioethics to the Church}

If anyone should be caring and paying attention, it is the evangelical church. The reason for this, partly, is that to be evangelical, or more precisely biblical, means to hold the particular view of the sanctity of human life summarily dismissed by Haynes's biological reductionism, and Singer's blatant ridicule. In short, the biblical proposition that humanity is 
created in the imago Dei should in itself produce a sense of obligation to engage in such attentiveness and care with a view to "preserving our humanity."

While biotechnology presents a most poignant challenge to the larger culture, the bioethical issues it surfaces should especially serve as an impetus for deliberate awareness and action in the local church; but such does not seem to be the case. According to Cameron, "bioethics and its myriad questions come low on any list of priority concerns" in the local church (Cameron, Daniels and White 2000, 76). Sadly, a continued silence is the legacy of the church when it comes to bioethical issues, particularly outside abortion, that threaten to undermine the very essence of what it means to be human. ${ }^{2}$

This reticence of the church has dire consequences for its own local community, where members are to minister to and care for one another, and the culture where the church is to be a prophetic voice as salt and light. Concerning the matter of community, as we move along in the twenty-first century the reality of biotech applications

${ }^{1}$ The biblical doctrine of humanity created in the imago Dei is central to this project and I will expound upon it in detail in the following chapter.

2 This was especially seen in the overall silence of the church in the late 1960s and early 1970s when Roe v. Wade was being decided. Hopefully, the church will not sleep through these new developments as post-Christian elitists seek to redefine and even redesign humanity. Even when churches do address abortion it may not even be perceived as a "bioethical" issue. It is, however, insofar as it involves the application of medical technology. The Bible does not explicitly address abortion, but the case is made that since Scriptures speak so highly of pre-natal life, induced abortion is tantamount to murder. Church leaders should be aware that the very propositional truths that are used to build a case against abortion are the same ones that should lead to attentive dialogue on issues such as birth control, cloning, assisted reproduction, genetic screening and others, yet these issues do not seem to be customarily addressed from the pulpit or in adult classrooms in local churches. 
mentioned above are all issues which evangelicals are or will be facing, thus rendering bioethics incumbent upon the church. "Because medical ethics is about moments in every human life, and because God is the author of every human life, there should be great concern in the church about medical ethics and, more comprehensively, bioethics" (Mitchell 1995, 124). Consequently, "Christians can no longer pretend, as it appears they may have in the past, that these dilemmas do not have implications for every believer" (Mitchell 1995, 135). As God's people continue to lack insights informed by God's word concerning the bioethical issues they will inevitably face, "at best they will continue to capitulate to so-called 'experts' all the while intuitively feeling that something is not quite right about the direction they are leading us" (Mitchell 1995, 132). Cameron gives the example of an infertile Christian couple seeking to become pregnant but failing to "grasp the moral significance" of reproductive technology and treatments like in vitro fertilization and surrogate mothering. What Cameron bemoans is that this representative couple has "no context for their decisions set in Christian education within the local church" (Cameron 2000, 77).

Mitchell sees the church as "God's primary instrument for the care of his people" with "responsibilities to itself, as a community, and to individual Christians who comprise the body of Christ" (Mitchell 1995, 124-5). Yet, "Grievously," he decries, "most churches have neglected the aspects of its 'internal' ministry which best prepare it to ... address the dilemmas that arise in contemporary bioethics" and, in his view, are "more poorly equipped to answer the dilemmas faced in bioethics" than at any time in history (Mitchell 1995, 130, 135).

People who do not know the way can be no guide to others. The longer biotechnology advances without a Christian voice informing the bioethics that evaluate it, it 
will by default develop under a secular framework. Ironically, the church can actually contribute to the secularization of bioethics (Cameron 2000). When the church fails to articulate bioethical issues from the perspective of a distinctively biblical worldview the secular framing wins the day; both in the minds of God's people and in the culture where the uniquely Christian voice is muted (Cameron 2000). This will only "compound the process already sadly visible around us, in which the distinctives of the Judeo-Christian worldview are incrementally lost as believers accommodate their moral vision to that of the world" (Cameron, Daniels and White 2000, xii). As this happens not only will society consider the church more of an anachronism than it already has, but the very dignity of human life will be jeopardized, and "Worse, we [the church] will be aiding in the assault on human life" (Mitchell 1995, 132)!

While there is pressing need for preparing people to engage the culture, the first order of business must be this equipping ministry within the local church community itself. The fact that biotechnology is facing humanity with radical, and not necessarily desirable, change in this world gives this educational endeavor great urgency.

\section{Answering Objections}

Is bioethical education obligatory in the local church? Some Christians no doubt hear the word "bioethics" and perhaps conclude that this has nothing to do with spirituality or spiritual growth in the Christian life. In fact, they may think of one or several objections to make this point. Perhaps the most prominent is that it will distract the church from its real priority; evangelism. Some may also think that it is too academic, meaning that most people in church are not educated enough to deal with its complexity. Another 
objection is that bioethics is a "clinical" matter for ethics committees in hospitals. Others might consider it too political, and thus having no place in church where we don't mix sacred theology with secular politics. Certainly some object that bioethics is way too controversial and, being such an area where opinions even among God's people may so vary, is better left alone. Finally, there is the quite tenable objection that bioethics surfaces issues that are far too personal to discuss in a local church. I will answer each of these in turn.

\section{Bioethics is not evangelistic.}

The objection goes something like this, "The first priority of the church is to evangelize, spread the gospel and get people saved. Anything that detracts from this priority is unacceptable. Bioethics involves issues that really have nothing to do with getting people saved." Bioethics, so the argument goes, involves social concerns, and, after all "as for social activity we [evangelicals] have tended to say it is largely a waste of time ... when the house is on fire, what is the point of hanging new curtains or rearranging the furniture? The only thing that matters is to rescue the perishing" (Stott 2006, 24).

By way of response, Christ did not leave His church with only an evangelistic but also an educational mandate. Along with "preach the gospel to every creature" (Mark $16: 15)$ is the charge to "make disciples of all the nations, teaching them to observe all things that I have commanded you" (Matt 28:18-20). ${ }^{3}$ It seems that it is just as important to our Lord that those who become His disciples understand the place His commands/teaching should have in their daily lives, as that they believe.

${ }^{3}$ Unless otherwise noted, all biblical quotations will be from the New King James Version (NKJV) of the Holy Bible. 
In the epistles, we see the first fruits of the church's efforts to implement this educational task. We find in them the ethical implications of the gospel for the different cultural settings in which His first followers found themselves. Bioethical issues intrinsically deal with such primal, personal and universal human experiences as conception, pregnancy, birth, sickness, health, disability, disease, aging, death and dying. This automatically lends itself to areas where Christians can practically minister to one another in the body.

Another thing worthy of note is when the church takes bioethics seriously enough to teach about it, this actually helps evangelism. As noted, bioethics deals with human life in its most primitive and universal aspects, so just as attention to bioethics will help the community to minister to one another in the body, for the same reasons attentiveness on the part of the church to these universal and social matters can open doors of opportunity for evangelism. The Lausanne Committee for World Evangelization observes,

When people encounter infertility, illness, and the fragility of their own bodies, and when they confront their own mortality as they observe or experience the dying process, the illusion of control over their lives is threatened or even shattered. Where will such people turn for help with their questions and the decisions they must make about medical treatments? If Christians become known as reliable and thoughtful sources of information and counsel about these issues, opportunities to present a Christian view of life, meaning, suffering and death will arise. The questions at the heart of bioethics are also at the heart of the gospel. (LCWE 2005, 7)

Further, "the way we 'do' Christian bioethics should witness to God's grace and love towards sinners. Love, acceptance and the offer of forgiveness ought to characterise our discussions" (LCWE 2005, 7).

It should be clear that rather than a correct understanding of the gospel taking us away from bioethics, it leads us right into the heart of it. Childs opines, "The concerns of ethics belong to the witnessing life of the church; they are part and parcel of the gospel 
mission in the world" (Childs 1992, 22). He sees the church's addressing of these issues as "not a substitute for proclaiming the good news," nor as "separate from evangelism either," but rather as of "critical importance for understanding the ethics in the life of the church" (Childs 1992, 22). Attention on the part of the church toward bioethics is not a matter of the gospel (evangelism) or ethics, but rather both evangelism and ethics, especially seeing bioethical challenges as opportunities for articulating the realities and relevance of God's gospel revelation.

\section{Bioethics is too academic}

Some say that the complexity of bioethics makes it inappropriate as a subject for church ministry, preaching and teaching. People need to be taught about the Christian life, not medicine and science. Further, people are generally not educated enough to deal with such subject matter in the church.

While bioethics, as such, is clearly an important discipline for specialists in academia, its subject matter, as we have seen reaching from conception to death, makes it relevant to all humans regardless of their level of formal education. Despite the growing sophistication of biotechnology, it still deals with the most primitive, personal and universal human experiences of life and death. If understood in this way, it should become clear that there is no question that bioethics is a relevant concern of a mature biblical spirituality that calls us to "do all to the glory of God" (1 Cor 10:31, cf. Col 3:17), and bring "every thought into captivity to the obedience of Christ" (2 Cor 10:5). Consequently, it would seem clear that,

Christian bioethics is fundamentally an ethics of the whole people of God. Ethical discernment is a corporate activity, and is not just a matter for a select band of clever 
professional bioethicists considering bioethical studies ... And just as this discernment is not just a matter for a bioethical elite, so it is not limited to an ecclesiastical elite. (Song 2005, 340-1 emphases mine)

While there is a definite and indispensable need in the church for those with bioethical prowess due to their educations, 4 there is also a necessity to teach God's people how to filter the bioethical challenges they face by instructing them in how their faith weighs in on answering these complex concerns. We will explore a model for this kind of education in chapter two.

\section{Bioethics is too clinical}

When people hear the term bioethics they think, perhaps, of highly educated people engaging in medical concerns; the things discussed by doctors and nurses and research scientists. This discussion has no place in the church, let alone between a pastor and his people, whether in individual counseling or pulpit ministry. If a couple has a question about infertility treatments, for example, they go to their doctor, not their minister.

Verhey notes, "Long before bioethics became a distinct field of inquiry. . . Christians ... were engaged with moral questions posed by medical care" $(2003,12-13)$. It should come as no surprise that Christianity has always put significant emphasis on healing, seeing its Founder came to earth as the Great Physician. Christianity's interest in bioethics stems from its taking seriously the healing ministry of Jesus of Nazareth. He set the precedent for valuing and caring for the physical body by healing it (Mark 4:23), and then

4 For discussion on the role of the moral theologians and bioethicists in the local church see Verhey (2002, 4-5 and 2003, 30-31, 49-50). 
charging His disciples with a similar ministry (Luke 9:2, 10:9). This healing was impartial and inclusive of even the most socially outcast like the poor, the leprous, the mentally ill-people commonly considered un-useful to society-and this precedent was set long before these people could even hope to find extended care in a hospital or clinical setting (Verhey 2003).

Jesus' first followers did not only see Him as the Great Physician, just as significantly they saw him as the Great Patient, or "Sufferer." This was the case because Jesus purposely identified with "the least of these" making care for the sick, the poor and needy tantamount to caring for Him (Matt 25:36-40). '“I was sick and you looked after me.' These words did not go unheeded. History shows that Christians not only opposed abortion, infanticide and abandoning infants, but they also nurtured and cared for the sick, regardless of who they were. Christian, or pagan, it did not matter to them" (Schmidt 2001, 151). So not only were Christians following His healing example, they were also ministering to Him when they cared for the ill and injured. Indeed, they "saw in the sick the very image of their Lord" (Verhey 2002, 128). The important thing to remember for our purposes is, whether thinking of Jesus as the model healer, or the model patient, "In memory of Jesus medicine was regarded less as an elite guild and more as a form of service to the sick" (Verhey 2002, 127). "In memory of Jesus the Christian community turned toward the sick, not against them, caring for them in their suffering and attending to them in their dying, practicing hospitality to them rather than ostracizing them from community" (Verhey 2002, 128). This all happened, "long before medical ethics became a distinct field of inquiry in the last third of the twentieth century, long before it became a growth industry in the academy" (Verhey 2002, 81). 
On this account it seems quite natural that the present church would, even should, have an invested interest in bioethics. This interest should be promoted in the church, not just by and for those who study medicine or philosophy, but by and for all those affected by the primitive and personal experiences of conception, pregnancy, birth, health, sickness, disability, disease, aging, dying and death; in short, all of us.

\section{Bioethics is too political}

The church is not a political institution, it is argued. Bioethical issues have too much to do with politics and matters of public policy and legislation. What place do policy matters on cloning and embryo research have in the church?

This refusal is based on the incorrect, yet putative, assumption that "religion and politics don't mix." This is problematic since the church itself is a political institution. References to "kingdom", "Lord," "citizens" and "city" are all political metaphors intended to draw our attention to the nature of the church as a political body. In light of this, Song's observation becomes quite significant.

The nature of its allegiance to Christ renders it a specifically political community which is ruled by its risen Lord. The Lord reigns, declared the Psalmist (Psalm 93.1), an avowal which is precisely echoed in Jesus' proclamation of the good news of the "kingdom of God." The Church is a political society which is defined by its recognition of the reign of God. (Song 2005, 335 emphasis his)

To help us conceptualize His church, the Lord inspired the biblical writers to cast it in the familiar language of citizens living together under common authority structures.

This understanding is important for at least two reasons. The first has to do with allegiance. We must remain vigilant lest we give our allegiance to any other lordship (Song 2005, 335). This allegiance takes on serious importance in that the church "cannot 
surrender the Lordship of Christ to any other lordship," or "never subordinate itself to alien political demands ... Indeed as an alternative polis it is fundamentally subversive of all other political claims" and any "allegiance outside of itself is tantamount to a kind of treason" (Song 2005, 335).

Second is the matter of influence. Stott brings clarity to our thinking by explaining that the root word polis, in a general sense, denotes the "life of the city" and the responsibilities of citizens to one another in that city. Politics, broadly speaking, "is concerned with the whole of our life in human society ... [it is] the art of living together in a community" (Stott 2006, 34). The narrower definition, according to Stott, is that "politics is the science of government. It is concerned with the development and adoption of specific policies with a view to . . legislation" (Stott 2006, 34). Stott concludes, "If we truly love our neighbors, and want to serve them, our service may oblige us to take (or solicit) political [in the narrower sense] action on their behalf" (Stott 2006, 36). Elsewhere, Stott cites the Bournemouth Declaration of November 1996 in which 2700 evangelical leaders agreed,

We recognize that no area of life is outside God's sovereign rule. We take the incarnation and transforming work of Christ as our model for engagement. We affirm our commitment to releasing Christian people for involvement at all levels of society. (Stott 1999, 26)

Stott identifies some of these "levels of society" for practical Christian engagement.

As conscientious citizens they will vote in elections, inform themselves about contemporary issues, share in the public debate, and perhaps write to a newspaper, lobby their [political leaders and representatives], or take part in a demonstration. Further, some individuals are called by God to give their lives to political service, in either local or national government. Christians who share particular moral and social concerns should be encouraged to form or join groups which will study issues at a deeper level and take appropriate action. $(1999,29)$ 
Another important voice on this matter of the political is Hauerwas. He

opines,

Attempts by Christians to avoid political involvement because of the "dirty" nature of politics are rightly condemned as irresponsible, if not unfaithful. Rather, it is the task of Christians to be politically involved exactly because we recognize that our politics involves compromise and accommodation. To withdraw from the political in order to remain pure is an irresponsible act of despair. (Hauerwas 1981, 73)

To address the role of believers as influencers of public policy is outside the scope of this project, but I have briefly included a discussion about it in answer to the objection that bioethics is "too political." It is precisely because it does involve political debate, and the discussion of public policy, that the church should care about bioethics.

Christians must participate in what is already an international conversation on the part of nearly every literate sector of society about what humanity will look like once we become fully fluent in the lexicon of human genetics. For persons of biblical faith to play a constructive role in that conversation will test our theological depth, scientific literacy, moral vision and political savvy. (Stassen and Gushee 2003, 252)

The shaping of public policy is inevitably going to shape our lives, the lives of those we love, and the lives of the individuals in our society, and bioethics, as we know by merely watching the evening news, is central to public policy discussions already.

\section{Bioethics is too controversial}

Childs recounts a time when he was presenting a rather complex and politically charged ethical issue in a local church. As he proceeded, he could sense his audience's growing restlessness and resistance. Eventually, someone spoke out. "I don't know why we are talking about such things in church, we have a happy, friendly congregation here ... we like to come to church and hear the good news. If we start talking about issues like these, it will only divide us and spoil our peaceful congregation" (Childs 
1992, 10). Verhey correctly points out, "Sometimes churches would prefer to avoid hard conversations about hard choices; hard moral choices, after all, can sometimes tear a community apart. No wonder, then, that churches are sometimes inhospitable to conversations about those choices" (Verhey 2002, 7-8). Nevertheless, he also wants us to realize, "If churches know who they are and what fidelity to their tradition and vocation requires of them, then they can 'do no other' than to struggle with the hard tasks of moral discourse and discernment" (Verhey 2002, 8). These are precisely the choices that churches should talk about because they are precisely the issues that give the church a relevant voice to the members of its own congregation as well as its surrounding culture.

Childs observes, "The life of the church as we experience it in the congregation frequently can be rather narrowly focused and characterized by the avoidance of difficult issues that should be a matter of Christian reflection and growth" (Childs 1992, 10). The underlying assumption of this objection is that the church, to maintain unity, must not address complicated, controversial subjects such as are inherent to bioethics. People come to church for comfort and consolation, not to confront moral problems, and the fear is that these discussions will divide us as it raises awareness of just how much we may differ from each other politically, theologically and otherwise. This implies that to maintain unity, we must reduce our ethical and theological commitments and convictions to the lowest common denominator. In this context, "we not only avoid certain aspects of our calling as Christian witnesses in the world, but also deny each other the gifts we can bring to the task through sharing in the congregational community" (Childs 1992, 10).

Christ's community is a community of diversity, not uniformity. If we do not collectively discuss the bioethical issues that shape our time within the context of our faith, 
we are left to struggle, and even suffer, on our own with some of life's greatest questions and challenges. "Unless we make the connections [of ethics to our faith] ourselves," states Childs, "we must carry on those struggles without the benefit of understanding how our faith and hope in Jesus Christ can provide the moral compass we require" (Childs 1992, 10). Too many people wish to remain comfortable in the status quo, but this results in an immature understanding of our faith and reduces congregational life to easy answers and uniformity rather than true unity and maturity. It stunts our spiritual growth in love and true unity within diversity, which is what the Apostle Paul envisioned for the church in its earliest years and conflicts (Rom 14:1-15:7). Yes, these issues can be "bitterly controversial," but "we need to be able to speak and hear the truth in a context of love and mutual support and concern. Only in such a context can faithful Christians thoughtfully relate the facts of the case to their religious convictions and then go on to make responsible actions" (Brill 1979, 217).

\section{Bioethics is too personal}

Throughout this discussion on objections I have reiterated that bioethics entails the most intimate and personal human experiences so as to render bioethical education incumbent on the church. But there is a way in which these same experiences can lead to another, and quite tenable, objection.

These personal and intimate experiences hold such capacity for vulnerability and potential pain that discussion about them, in the minds of many, is out of the question; privacy is the only option. Much of the reason that bioethical issues become controversial and are ignored is that people who have faced or are facing serious bioethical challenges, like 
the pregnant teen, or the post-abortive woman who has suffered with guilt for years, or the couple that had in-vitro fertilization (IVF) treatments several years ago but now has no clue what happened to the unused embryos, and no way of finding out, understandably wish to avoid the critical eyes and words of their fellow members. They do not feel comfortable or safe turning to their community of faith with their struggles because they anticipate only harsh condemnation toward their moral failures, rather than loving support (Verhey 2002).

It is unfortunate that churches create such an atmosphere of fear. This apprehension leads God's people to keep their personal bioethical struggles shrouded in secrecy and even suffering, leading to a shallowness of growth in some of the most important questions we face individually and collectively. As churches focus more on bioethics, and thus highlight the biblical doctrine of the sanctity of human life, they should expect a response of guilt from some who consider their past bioethical choices to be moral failures. Here, the redemptive message of God's love and grace must abound in the church. We are all moral failures, and we should reach out redemptively to those who are struggling. An atmosphere of love, acceptance and forgiveness in the church, where God's people can safely speak of their bioethical struggles and failures is a vital part of developing an environment where bioethics takes a more prominent role in local church ministry.

\section{Project's Relation to the Ministry of the Writer}

I remember hearing in undergrad Bible classes at Liberty Baptist College (now Liberty University) how the Apostle Paul arranged his epistles by addressing the theology in the first half, and then the ethics that derive from that theology in the second half. It fascinated me how practical biblical theology was, and early in my Christian life, I 
developed the conviction that the Bible was inspired, infallible and authoritative for all matters concerning Christian faith and practice. This meant understanding the ethical implications of the gospel; I was called not only to believe a certain way through the Bible, but also to live a certain way in light of it.

Presently, I have the privilege of serving as a layman in a local church whose pastor, Dr. F. Gerald Kroll, was one of my professors in my undergraduate studies. This is an important detail for as I reflect back on my early years in college in the early 1980's I realize that Dr. Kroll taught two of the most formative courses that I took as an undergrad, and a new Christian. He first introduced me to the thought of Francis Schaeffer in a video series entitled, Whatever Happened to the Human Race, whetting my appetite for thinking about bioethical issues from a biblical standpoint. He also later challenged me to understand the cultural relevance of Scripture in a homiletics class he taught. These two classes in my first two years as a believer and biblical student produced in me a desire to relate the Scriptures to ethical issues.

Dr. Kroll has since moved on to a senior pastorate at Heritage Baptist Church (Hence HBC) in Lynchburg, VA where I have been attending with my family since $1997 . \quad$ I have noticed that as a preacher, Dr. Kroll continues to address, or provide educational opportunities for addressing, issues of social importance, and matters of the Christian's engagement with the culture from a biblical perspective.

I received my M.Div. from Liberty Baptist Theological Seminary in the spring of 1992, and was ordained that fall. I have never held an official pastorate, but in 1995 I was hired to teach a course on contemporary ethical issues at Liberty University, the same class taught by Dr. Kroll back in the early 1980s when I first attended Liberty! 
These classes I teach are required for all undergraduate Liberty students in their first year at LU. In this capacity I understand my primary responsibility to be to provide an affirmation of a biblical theistic worldview and a biblical approach to ethical decision making and then the application of that worldview to specific contemporary ethical issues; I have found my niche. In my capacity as a lay minister at $\mathrm{HBC}$, I have been able to transfer much of the material I develop in my academic courses at Liberty to the context of the local church.

Something else I do is serve as a member of HBC's Community Action Committee as an educational resource. In this capacity my passion is to bring the issues of worldview and (bio)ethics into the local church setting. I have been given that opportunity through being allowed to teach an annual elective specifically addressing bioethical and other social issues, and occasionally addressing the congregation as a whole on contemporary issues. I have found that God's people are hungry for this knowledge and application, and especially for the community dialogue that I encourage in the process.

My experience at this level of church ministry has convinced me that there is a definite need for churches to address bioethics from the standpoint of the biblical worldview to encourage and equip God's people to enter into substantive dialogue over how this worldview practically bears upon their existential concerns. But beyond the mere educational (classroom) level, I have a desire to see the church in many different ways address issues dealing with bioethics, particularly as they impact the matter of human dignity, throughout its life and ministry. 


\section{Current Literature on Bioethical Education in the Local Church}

In my research, I have become acquainted with several authors who share this concern. What I have been impressed with in terms of doing ethics within the context of the local church, and outside of the academy or university, is the two-fold emphasis on the community and the gospel.

University ethics classes, whether teaching ethical theory or applied ethics, necessarily focus upon people: Socrates, Kant, Bentham, Mills, Rawls; certain schools of thought and their historical development: utilitarianism, deontology; or principles: justice, autonomy, beneficence, categorical imperative, etc. These are indispensable aspects of a formal ethical education, and those taking ethics in college or who go on to teach this discipline should expect and be expected to demonstrate proficiency in articulating ethics in such categories. But in the church community, what needs to be the focus, according to the following authors, is not so much prominent people, schools of thought, or principles, as the community of God's people gathered around God's word asking questions about how their present bioethical challenges fit into and are informed by the story of biblical redemption, culminating in the Gospel of Christ. I will justify this methodology and develop a model for its application in the next chapter. For now, I will simply illustrate how this emphasis is prominent in a sampling of some of the current literature.

The Lausanne Committee for World Evangelization has recently addressed the issue of bioethics and its relationship to evangelism. They conclude that since bioethics is becoming so prominent in the world, the church cannot ignore it if it is going to present the gospel with real-world relevance. They see bioethical challenges not as obstacles but opportunities for evangelism. They tie the gospel to bioethics as follows. 
Christian bioethics is based on the self-revelation of God in Jesus Christ, witnessed to by the Old and New Testaments. The community of faith transmits the tradition of God's saving acts in history, culminating in the story of the life, death, resurrection and ascension of Jesus of Nazareth. This story provides the framework within which Christians interpret the world and their relationship to it. As the church remembers, retells and reflects on this story, she allows herself to be actively shaped by the Holy Spirit. (LCWE 2005, 9)

Noteworthy is how the committee bases bioethical reflection on God's revelation in Christ, the biblical narrative or gospel, as the framework which the community of faith is responsible actively to remember, retell, reflect upon and transmit.

Another important evangelical voice is that of C. Ben Mitchell, Associate Professor of Bioethics and Contemporary Culture at Trinity International University, and Senior Fellow for the Center for Bioethics and Human Dignity. He contends that Christians are ill-equipped to address the bioethical dilemmas of our day largely because the local church, with its penchant for church growth-defined in terms of "bigger buildings and budgets" -has been remiss in the work of cultivating the Christian mind in God's people. "The heart of this task of recovering the Christian mind-helping Christians think Christianly -is the goal of recovering and further developing a biblical ethics that is sufficiently informed and enriched to deal with the complexities of high-technology medicine and the dilemmas it sometimes presents" (Mitchell 1995, 131). To so equip Christians is the responsibility of "pastors, elders and deacons" and entails that churches "spend a great deal of pulpit and class time seeking to understand what the Bible says about the Creator and what he says about life and death" as well as "a great deal of time ... trying to understand the results of Adam's fall and its implications for disease and death ... not topics which occupy much of the teaching ministry of the local church" (Mitchell 1995, 131). So here, Mitchell casts the task of the church in terms of articulating the biblical narrative as the context for bioethical reflection. 
He also emphasizes the community aspect of this task. "The importance of 'community life' is no less critical in the realm of bioethics than in other areas" (Mitchell 1995, 132). He speaks of "creating a moral community" defined as "a body of believers who are selfconsciously and consistently living out the principles of the word of God" (Mitchell 1995, 132).

Glen H. Stassen and David P. Gushee, professors of ethics and moral philosophy at Fuller Theological Seminary and Union University, respectively, vie for what they call the "theological basic-conviction" approach. They point out that others have called this contextual or narrative ethics and explain it as such: "Christian ethics must and should be done in the context of our faith-communities, and our faith communities must do Christian ethics in the context of the theological narrative found in Scripture" (Stassen and Gushee 2003, 114). Holding true to this approach, in their chapter on biotechnology and bioethics they write, in answer to the potential problem that biblical ethics has no relevance to contemporary bioethical challenges, "Despite the gap between Jesus' context and our own, the theological basic-convictions dimension remains unchanged." In other words, "The basic biblical narrative . . is still true and still applicable in an age of biotech innovations - or any age" (Stassen and Gushee 2004, 253). And on this basis, they are convinced,

What needs to happen is a thoughtful encounter between Christ-followers, bound together in community, already practiced in a discerning way of life dedicated to seeking the kingdom, with the new issues demanding Christian response. Certain options, certain trajectories under consideration, will be rejected (or embraced) by such a community according to whether or not they 'fit' with the moral vision and moral character of this particular people. $(2003,254)$

And, of course, that moral vision and character is rooted in the "theological basicconviction" narrative of God's word that they expound throughout their book. 
James M. Childs Jr., Edward C. Fendt Professor of Systematic Theology at Trinity Lutheran Seminary, opens his work Faith, Formation and Decision: Ethics in the Community of Promise (1992), with two scenarios, one from the Old Testament highlighting Israel's community life and recitation of a Psalm and the Shema of Deuteronomy 6, and then a modern day scenario of a church gathering together for a communal recitation of the Apostle's creed. He then remarks, "There is a common theme that characterizes both of these scenes, ancient and modern .... In both cases the message is that community worship is the place of commitment to the good and right in the eyes of God and for the sake of the neighbor" (Childs 1992, 6). He says that this commitment is "couched in the recognition and assurance that the world belongs to God who in love has created it, redeemed it, and called it to new life and new possibilities" (Childs 1992, 6). He speaks of "the memory and promise of God's deliverance," that is, the narrative of biblical history, as providing a "frame of meaning and hope" to give an impetus for a loving response to God and neighbor (Childs 1992, 6). This sets the backdrop for his book. The community is not merely a byproduct but the very essence of God's work in His church, and the only context for dispelling moral confusion as it nurtures a particular viewpoint about life resulting in "understanding and trust of God (faith)," how this outlook shapes life and values and develops character (formation), and how we actually make choices about right and wrong (decision) (Childs 1992, 6).

Richard Eyer, also coming from a Lutheran perspective, and from a background of over thirty years of ministry as a parish pastor, hospital chaplain and now Director Emeritus of The Concordia Bioethics Institute, Concordia University, sees the Gospel as the unifying story of Scripture, in fact the story of history, and the only adequate foundation for meaningful Christian ethical reflection. "The Christian ethic is more than 
knowing our limits. It is about the new life created by the Gospel of Jesus Christ that gives meaning to all that we are and do" (Eyer 2000, 8). Eyer's main contention is that attempting to do ethics by merely appealing to the law is inadequate and that, "Ethics needs a story to give it purpose and meaning. The realization that story is crucial as a basis for ethics has reemerged in the search for a way out of the moral chaos" (Eyer 2000, 38). When Eyer refers to "biblical narrative" he is envisioning far more than the so-called narrative passages. Elsewhere he explains, "My use of the word narrative here simply means the whole story of our salvation from Genesis to Revelation with the center piece of that story being the life, death and resurrection of Jesus Christ. The story God tells reveals the meaning of our life together, and consequently our ethic under God" (Eyer 1998, 14). It is noteworthy that Eyer points out the necessity of the narrative and the community as well and in mentioning "the story of our life together" and "our ethic" he combines the ideas of narrative and community. "Story gives coherent meaning to our life together. Christians recognize the Story-the Bible-as the original foundation of our common life as human beings under God" (Eyer 2000, 38).

Sondra Ely Wheeler, Professor of Ethics at Wesley Theological Seminary, builds a case for how ethics is not the appropriate starting place for doing ethics for the church. Instead, in addressing "theologians," "pastors" and "Christians" she argues for our making decisions in the realm of medical ethics that are "consistent with our faith and congruent with our distinctive account of the meaning of life and the end of human existence" (Wheeler 1996, 15). She then opines,

The context needed to sustain the conversation that will help us to make such choices well in a [bioethical] crisis is the community of faith. Partly this is because we are among those who share our specific moral convictions and commitments, but more 
than that, it is because it is here that we are formed ... here that our vision of the world and our understanding of the choices we confront is deeply shaped by the story of God we tell. (Wheeler 1996, 15)

That story, she later explains, is what shapes the "communion of saints" and "reaches through time and space to embrace all who take its story of creation, redemption and consummation as their own" (Wheeler 1996, 20). Further, "This story of what God has done provides the framework within which Christians [in community] interpret the world and their [individual and communal] acts in it" (Wheeler 1996, 21). It is these "common convictions," or common story, in light of which "Christian ministers need to lead their parishioners and their communities in a process of discernment" (Wheeler 1996, 15).

This concept of discernment in light of the biblical story is central to Allen Verhey's approach to doing bioethics in the local church (Verhey 2002 and 2003). Verhey, Professor of Christian Ethics at Duke Divinity School, has made the concepts of narrative, or story, and community predominant in his methodology for this ecclesiastical task. His work is especially relevant to my project in that he seeks to "provide a coherent volume that joins the reading of Scripture with bioethics" (Verhey 2003, xii). Central to his ethical procedure is "discernment," and he applies it rigorously to such bioethical issues as suffering, genetic engineering, abortion, assisted reproduction, physician assisted suicide, neonaticide and infanticide, and finally the allocation of scarce medical resources (Verhey 2003). He envisions Christians reading Scripture communally, carefully and correctly so as to use it as a filter for discerning what, in these matters, we ought to do and ought to leave undone. He speaks of the early church setting medicine "in the context of the story it loved to tell and longed to live" as it struggled to "render a medicine worthy of the gospel" (Verhey 2003, 6). "Medicine," he continues, "had somehow to fit the story. The story reached, of course, from 
the creation to the resurrection to the 'redemption of our bodies' (Rom. 8:23), and at the center of this story was Jesus of Nazareth" (Verhey 2003, 6).

Verhey's works have resonated with me and will be central to this project. I hope to develop, in a sense, a methodology for engaging in bioethical reflection and education as the community of Heritage Baptist Church largely using Verhey's model for "reading Scripture" as the church with a view to discerning what we ought to do to live a life worthy of the gospel in matters of bioethics.

A very important, and seminal, author for this whole subject is Stanley Hauerwas. Hauerwas was, in fact, pointed out by Wenham to be "among [the first of] those who have rightly drawn attention to the communal setting of biblical ethics: that is the biblical text with its didactic message is at once the product of a community and also designed to create and perpetuate community" (Wenham 2000, 102). Hauerwas asserts,

To be a disciple is to be a part of a new community, a new polity, which is formed on Jesus' obedience on the cross. The constitutions of this new polity are the Gospels. The Gospels are not just the depiction of a man, but they are manuals for the training necessary to be part of the new community. To be a disciple means to share Christ's story, to participate in the reality of God's rule. (Hauerwas 19981, 50)

The late Gordon J. Wenham, former Professor of Old Testament at the University of Gloucestershire also weighs in on this from both an Old and New Testament perspective (Wenham 2000). His approving citation of Hauerwas demonstrates his awareness of this important phenomenon that started as soon as God called out His redeemed community. The Exodus story defines Israel's relationship to God, and the giving of the law is set in this context, informing Israel of its ethical responsibility in response to that story (Wenham 2000, 102). He sees continuity with the New Testament as evidenced by the fact that Paul's theology and ethic is set squarely within the framework of the grand narrative 
commencing in creation and culminating in the second coming of Christ. The New Testament writers' frequent reference to the Old Testament stories is "not simply to show the theological continuity between the testaments, but to draw out the ethical implications of the Old Testament for the New Testament church.” In other words, God continues to nurture His redeemed community through "this grand narrative which begins with creation and ends with Christ's second advent" (Wenham 2000, 130).

Professor of theology and ethics at Durham University, UK, Robert Song, observes that currently Christian bioethicists are more emphasizing that, "The distinctiveness of Christian ethics is given shape by the narrative of the community committed to the proclamation of Christ, and by grounding this narrative in the distinctive practices of that community, ..." (Song 2005, 334). Here again we see the idea of narrative centered on Christ (the Gospel) proclaimed by the community that derives from and is defined by that narrative.

Arne Rasmusson, Associate Prof. of Theology and Ethics at Umea University in Sweden, states, "the corporate character of the church, expressed in such language as 'people of God', koinonia, 'body of Christ', 'covenant people', 'household of faith' ... makes it also into a place for moral formation." (Rasmusson n.d., 184) Further, "Communal discernment is of course another name for ecclesial ethical reflection [and] in the Christian understanding these practices receive their meaning from the place of the church in God's purpose for the creation ... God's creational and saving purposes" (Rasmusson n.d., 185). So the context for this moral development is the community of believers, the church, who exercise "communal discernment" on the basis of the narrative of "God's creational and saving purposes." 
This brief overview of some of the modern literature is important because while it covers so many faith traditions; from Evangelical to Lutheran, to Wesleyan, to Reformed, to Catholic, what surfaces is a common conviction that transcends denominational views, and the two-fold nature of that common conviction; that the church's moral discernment should be nurtured within a community which is governed by the biblical narrative centered on the gospel of Christ.

\section{Goals and Objectives}

The purpose of this project is to propose a model for how a local church can equip its people to understand and engage today's crucial bioethical challenges within its life and ministry especially by means of gathering around God's word, and in particular around the church's theological tradition insofar as it reflects the major themes of the overall biblical narrative.

In view of this, I would like to propose the following goals for this project.

(1) To make a case for the urgency with which the local church must educate and equip its congregants about current bioethical challenges by $(a)$ illustrating the urgency sensed even by secularists $(b)$ providing a concise working definition of "bioethics" (c) identifying relevant bioethical issues with which God's people are already concerned but may neither understand as such nor their biblical implications. (2) To demonstrate how a church's standing doctrinal statement, its theological narrative, and philosophy of ministry may serve as the framework for addressing bioethical challenges it will face by $(a)$ taking numerous points of HBC's doctrinal statement and connecting them to bioethics and current bioethical issues and $(b)$ identifying areas in which the doctrinal statement could become more richly 
narrative oriented so as to include even more clear points of connection to bioethical issues.

(3) To educate the congregation about and improve their understanding of relevant bioethical issues and biblical responses to them by $(a)$ providing an educational opportunity for in-depth discussion about bioethical issues and $(b)$ presenting to the congregation as a whole a general overview of relevant bioethical issues and responses to them that are consistent with the theological perspective of the church's doctrinal statement/narrative. (4) To lead selected individuals from the congregation in an exploration as to how the church can further encourage bioethical understanding among its members in accordance with the doctrine and ministry goals of the church.

\section{Scope and Limitations}

First, I will not be providing any kind of formal or in depth instruction in moral philosophy or applied ethics. This will not be a philosophical treatise, but instead an exploration of practical theology. Its focus will be bioethical issues that all of God's people face anyway_ on account of the fact they are all dealing with matters of conception, pregnancy, health, illness, disease, disability, aging, dying and death in some form or another-formal education notwithstanding. My conviction is that the church must be educated to deal with these issues on a personal and congregational level using the grid of their theological narrative as the basis for bioethical discernment.

Further, I will make no attempt to develop normative polity or decisionmaking guidelines for every foreseeable bioethical dilemma. I intend to focus on Heritage Baptist Church's doctrinal statement and ministry goals and demonstrate how these naturally 
merge into dealing with selected bioethical issues. The way that these selected issues will be dealt with will provide meaningful resources for addressing further bioethical challenges.

Finally, I do not plan to assess at what level other congregations are addressing these issues, but instead will limit my analysis to the life and ministry of $\mathrm{HBC}$ in Lynchburg, Virginia. I will be operating under the assumption, however, that what we develop and apply at HBC will serve to inform and challenge other local churches as well as point them to methods and resources for engaging in this critical task. 


\section{CHAPTER 2}

\section{THE PROJECT IN BIBLICAL AND THEOLOGICAL PERSPECTIVE}

Anytime a person engages in bioethics they will bring to the task a set of presuppositions. These presuppositions reflect his or her worldview. Frequently, one obtains a worldview by default from parents, culture, peers, teachers, etc. A worldview by default, although influential, is not useful. Only as a person develops their worldview through deliberation, can she use it intentionally to guide her ethical decisions.

\section{Part One: Premises for Bioethics in the Local Church}

The Christian church should teach its people to articulate a worldview that is the outcome of careful deliberation, especially as it comes to the bioethical task. This deliberation can help a person to establish meaningful premises upon which he can make bioethical decisions. It will also help a church in their community dialogue over bioethics.

\section{The Christian Mind and Worldview}

In discussing the role of the church in contemporary bioethics, Mitchell decries how our penchant for church growth-which means in large part "bigger buildings and budgets"- has diverted attention from theology in our local churches, and states, "unless the church leads in the recovery of the Christian mind, the sanctuaries of God will become ineffective in the battle against Satan" (Mitchell 1995, 131). This "battle" is "one of argument, ideas, and notions, which set themselves up against God and revolt against Christ" 
(Mitchell, 1995 131). He continues, "There is a tendency of Christians, especially activisttypes, to do 'sound-bite' ethics. That is, there is a temptation to spout quick, good-sounding answers to some of the dilemmas of bioethics without thinking through these issues biblically. Perhaps as never before the situation demands a recovery of a thoroughly Christian worldview" (Mitchell, 1995 135). Consequently, he asserts, the "heart" of the task of bioethical education in the local church is "recovering the Christian mind," or "helping Christians think Christianly" which has in view, "recovering and further developing a biblical ethics that is sufficiently informed and enriched to deal with the complexities of high-technology medicine and the dilemmas it sometimes presents" (Mitchell 1995, 131). Mitchell has derived his viewpoints from Harry Blamires' important work The Christian Mind. Blamires posits that,

Before the Christian dialogue ... is the Christian mind-a mind trained, informed, equipped to handle data of secular controversy within the framework of reference which is constructed on Christian presuppositions. The Christian mind is the prerequisite of Christian thinking. And Christian thinking is the prerequisite of Christian action. (Blamires 1963, 43)

In Blamires' view, "the very bedrock of fruitful action" is nothing other than "the Christian mind" (Blamires 1963, 43). Churches tend to get the cart, Christian action, before the horse, the Christian mind, but for Mitchell, tantamount to the recovery of a "Christian mind" is the recovery of "a thoroughly Christian worldview." Cameron, highlighting the need for bioethics in the local church, likewise weighs in on the kind of education needed when he calls leaders to "engage their members in 'worldview' Christian living" (Cameron 2000, 77).

In light of this, when we speak about bioethical education in the local church there are at least two things that we do not mean. We are not referring to preparing people to 
shoot off Bible references-book chapter and verse-like silver bullets intended to resolve very complex bioethical dilemmas. These require far more reflection, and biblical references are easily wrenched from their immediate context, as well as the context of the Bible's greater narrative. Another thing we do not mean is bringing in an ethicist to hold a special meeting or conference and present a talk only to be given a courteous applause but then forgotten in a matter of days. We are not talking about holding an event, but rather cultivating an environment. 5

This environment means for the individuals and the community of a given congregation to have a well cultivated, comprehensive and coherent world view that involves an orientation of the heart toward God's big story, an immersion in and assimilation of the metanarrative of biblical revelation from creation to its final consummation, all centered on Christ, as a continually abiding framework for bioethical discourse, deliberation, discernment and decision.

The story we live by

In Naming the Elephant Sire analyzes worldview as a concept (Sire 2004). He perceives of it as "inextricably tied to lived experience and behavior," and having to do with a "lived reality" (Sire 2004, 98). A new and central recognition for Sire is that it is "a way of

5 This is meant by no means to diminish or demean the significance and work of Christian bioethicists or bioethics centers who have trained so painstakingly with a passion to bring an educated and intellectual Christian perspective to bear upon the issues of the day as they engage the culture in the university, the chambers of congress, TV and talk radio, or even speak to church congregations about contemporary bioethical challenges. But it would seem that they would agree that cultivating an environment of, and equipping Christians for, bioethical dialogue and discernment within local congregations is critical to their overall vision of transforming the culture to the glory of God. 
life that is bound up with seeing one's life as a part of a master story, a metanarrative" (Sire 2004, 97). ${ }^{6}$ His revised definition emerges as "A commitment, a fundamental orientation of the heart, that can be expressed as a story or in a set of presuppositions which we hold about the basic constitution of reality" (Sire 2004, 122). Worldview should not so much be thought of as a "matter of the intellect," but as a "grand story" (Sire 2004, 123).

From this perspective, the concept of worldview unavoidably involves story, and puts it on a par with other stories. All literature, folklore and myth from every culture tell "stories that put present human reality in the large context of universal cosmic and human meaning" (Sire 2004, 100). These stories serve as "orienting patterns" and explain why things are the way they are in the present. They are "stories by which societies interpret the universe and life around them" (Sire 2004, 100). It is a common move of human beings in every culture to tell such stories as a backdrop, or larger context for present beliefs and behaviors. $^{7}$ Sire even sees this tendency toward metanarrative within most philosophical

"New" is a reference to Sire's previous discussions of worldview in his The Universe Next Door. Sires also makes frequent reference to this work in Naming the Elephant insofar as he is revisiting the concept and evaluating his earlier, more cognitive and propositional exposition of worldview.

${ }^{7}$ In reality, our bent towards story telling is even seen in our insatiable thirst for T V series, movies and songs. Every TV serial, movie and nearly every song, tell stories. We love telling stories, and hearing stories. This seems to be intrinsic to what it means to be human and even separates us, still further, from animals. When animals tell stories in books or films, these are anthropomorphisms. So to find the Bible to be a book of stories that actually combine to tell one master story should be no surprise. God's communication with the beings He made in His image should largely be expected to be a story; and this is exactly what we find. God's affinity for story telling resonates with ours as humans. 
systems. ${ }^{8}$ In light of this, he suggests that a purely cognitive emphasis in worldview study may be "quite inaccurate" $(2004,101)$. "Does [this emphasis] not miss an important element in how people actually think and act ... would it be better to consider a worldview as the story we live by" (Sire 2004, 101 emphasis his)?

This should really come as no surprise since the Bible itself is mostly presented as story, and even the didactic and poetic passages are "all . . embedded in story" (Sire 2004, 102). Eyer observes,

A common story has a beginning, a middle and an end. This narrative structure ties together all the parts into a meaningful whole. All stories attempt to make sense of the raw material of knowledge and experience that would otherwise be perceived merely as random data. Stories are powerful because they give coherence to our lives and affect the way we think and act. (Eyer 2000,38)

Wenham, pointing out the "oversight" of biblical narrative in both Old and New Testament scholars, speaks of "the great story line ... that rarely receives the attention it deserves" (Wenham 2000, 129). It is the Bible's story that we are urged to receive, according to Leslie Newbigin. "The dogma, the thing given for our acceptance in faith, is not a set of timeless propositions: it is a story ... a vision of cosmic history from the creation of the world to its consummation" (Newbigin 1989, 12). Carson also emphasizes the Bible's "plot-line" when he speaks of the

${ }^{8}$ Sire notes how all post-enlightenment systems that attempt to denounce metanarratives are self-refuting in that they themselves are "story-ful" in those very attempts. He explains "Naturalism itself relies on evolution to explain the universe in general, what we are as human beings and how we got this way. Postmodernism tends also to be historicist seeing the whole of how we understand ourselves and God (if any) to be bound up with the ebbs and flows of culture and societal change" (Sire 2004, 100). 
Importance of adopting "the whole counsel of God," of recognizing the distinctiveness of an entire Christian worldview if the parts within it are to make much sense. That means not less than following and adopting the Bible's plot-line. In other words . . the Bible provides us with a metanarrative, a comprehensive "story" that provides the framework for a comprehensive explanation, a . . worldview. (Carson 1996, 191)

Childs adds, "Ethics can never be understood simply in terms of a set of principles that tell us what is right and wrong. Unless those principles are a consistent expression of our basic outlook on life, our faith, and dispositions, they may not make much sense to us, they may not be very important to us" (Childs 1992, 6). Could it be that bioethics do not "make much sense" in the minds of God's people because they lack a Christian mind, a worldview, a master story, as a framework for the work of bioethical discernment?

\section{Personalizing the plot-line}

The biblical story is for "the nations." God told Abraham, "in you shall all the families of the earth be blessed" (Gen 12:3). Paul, owning this Story, points out that all who put faith in Christ Jesus are also sons of Abraham, tying the lives of all who believe in Jesus Christ to this master story of the Bible. The Gospel of Jesus Christ is, in fact, the culmination, the center-piece, of the metanarrative, and the means by which God would eventually apply the universal promise given to Abraham to "all the families of the earth" (Gen 12:3; Rom 4:13-25; Gal 3:26-29).

This perspective of the Bible as a "universal history" (Newbigin 1989, 89) leads us to a very personal, and eventually personally ethical (and bioethical), dimension of the story. "When we accept this story in the fashion God has intended, we do so not just as 
an intellectual assent. We do not just believe it at a distance. We are to indwell it as if it were our own story, because it actually is" (Sire 2004, 105 emphasis his).

If, as Sire suggests, "the biblical narrative puts us in contact with the way God, we and the world really are" (Sire 2004, 105), it also puts us into contact with how we should live our lives faithfully within that continually unfolding story. This is the point of engagement for many writers, as we saw in chapter one, of a distinctively Christian bioethics. Essentially, they assert that it is not merely through trying to find a biblical text that addresses our issue, or even in appreciating the narrative nature of the Bible, but more in accepting it as our story. Ethics, roughly defined as the discipline of discerning principles and values to govern our character and conduct, does not start for the Christian with abstract and distant philosophical theory, but with a concrete and personal story.

Major Motifs in the Biblical Metanarrative

Having established that a biblical worldview is appropriately, and perhaps best, thought of as a metanarrative, it remains to articulate that worldview. Once we do this, we can apply it to the process of bioethical discernment.

\section{Overview}

Emphasis on worldview as metanarrative or "story" by Christian thinkers is not new. Colson and Pearcey have defined worldview broadly as "a comprehensive life system that answers all of humanity's age-old questions" (Colson and Pearcey 2000, xi). Interestingly, although they do not explicitly delve into worldview as metanarrative, they still frame worldview as a "story" when they propose that "any worldview must answer" the 
following "central questions" within three categories. (1) Creation; Where did we come from, and who are we? (2) Fall; What has gone wrong with the world? and (3) Redemption; What can we do to fix it? (Colson and Pearcey 2000, xiii).

Others, like Sire, see this conceptualization of worldview as master narrative more explicitly. According to Sire, Christianity involves a "pattern of creation, fall, redemption and glorification" (Sire 2004, 126). He also speaks of Middleton and Walsh's selection of "three themes" as "central to the Christian worldview: the doctrine of creation, the fall of humanity into sin, and transformation through Christian redemption" $(2004,96)$. Newbigin envisions a "cosmic history from the creation of the world to its consummation" (Newbigin 1989, 12). Wheeler refers to the "common story" that binds the "communion of the saints" as being "creation, fall and consummation" (Wheeler 1996, 20). Blocher, writing explicitly for bioethics, speaks of the master narrative of Christianity involving "four foundational principles of the Christian worldview" being Creation, Fall, Redemption and Consummation (Blocher 2004, 2). Finally, Verhey in preparation to “"map' human genetic knowledge and powers" speaks of providing "an orientation for Christians in light of the remembered story" and traces it as a narrative that "begins with creation, continues with covenant, climaxes in the Christ, and promises renewal of all things by the Spirit" (Verhey 2003, 158-9).

\section{Biblical Narrative and Bioethics}

In light of these schemata, I propose the following major motifs of the biblical metanarrative: Creation, Corruption, Covenant, Consummation and Christ. I will presently develop these as the framework for all of our practical discourse and discernment as a local 
body of believers seeking to make Christ honoring bioethical decisions. For Verhey, bioethics in the local church comes down to realizing that, "In Christian community ... discernment regards decisions as the recognition of what is fitting, or coherent, with the ... narrative in which Christ is the center" (Verhey, 2003, 61). "In the light of that story Christians struggle to shape their lives into something worthy of the gospel" he adds (Verehy 2003, 159). Throughout this discussion, "the Story" will be a comprehensive reference to the entire biblical metanarrative constituted by these five major motifs.

\section{Creation and Bioethics}

Imago Dei. Biotechnology concerns the application of the information and techniques of biological science to human well-being. Bioethics inquires as to whether and how it should be applied. As such, foundational to biotechnology and bioethics is anthropology. "Particularly in the face of emerging biotechnologies, we need a clear anthropology — a clear understanding of who human beings are and, by implication, how they may or may not act toward one another in the world" (Mitchell et al. 2007, 58). Hoekema puts into perspective how biotech questions inevitably call up more foundational anthropological questions.

Practices such as artificial insemination, test-tube babies, abortion, chemical control of behavior, euthanasia, genetic engineering, and the like, raise questions about the dignity of human life ... one can see why the question 'What is man?' has acquired a new urgency today. (Hoekema 1986, 2)

Cameron sees the "need to prepare this generation for the redefinition of our humanity, and to teach believers how to live out the vision of human dignity made in God's image in a 
bioethics culture where such a vision is being supplanted" (Cameron 2000, 77) as the core of the educational task of the local church with regard to bioethics.

Really, when it comes to making a biblical case for the incumbency of bioethical education in the local church, one need look no further than Genesis. Hoekema identifies the doctrine of human beings created in the image of God as the "most distinctive feature of the biblical understanding of man" (Hoekema 1986, 5). "Human dignity is grounded in humanity's unique connection with God" not an inherent divinity or worth apart from this connection (Mitchell et al. 2007, 70).

In the Creation Story (Gen 1:26-28, 5:1) the word "image" is derived from a root meaning to "carve" or "cut out," and likeness denotes "to be like" (Hoekema 1986, 4). These two terms are generally recognized as synonymous throughout Scripture and convey the sense "of an image truly representative of God" (Mitchell et al. 2007, 70). The emphasis of the Story at its outset is that God created humans to be his representatives in the earth. Yet, beyond the strictly functional idea of being God's representatives, human identity is very closely and essentially related to God to the point that the Bible claims that killing a human is tantamount to disregarding the image of God in man (Genesis 9:6). Hoekema explains,

The reason that murder is said here to be such a heinous crime that it must be punished by death is that the man who has been murdered is someone who imaged God, reflected God, was like God, and represented God. Therefore when one kills a human being, not only does he take that person's life, but he hurts God himself. To touch the image of God is to touch God himself; to kill the image of God is to do violence to God himself. (Hoekema 1986, 13)

In Psalm 8 David owns this Story. In answer to the question, "what is man that You are mindful of him?" (Psalm 8:3-5), the answer is, "You have made him a little 
lower than God (v.5).” Hoekema argues that the Psalm recollects Genesis 1 by placing man "a little lower than God." Allen translates v. 5, "But you have caused [man] to lack but little of God; and with glorious honor you have crowned him" (Allen 1984, 71). Allen concludes, "In response to the question 'What is man?' comes an answer of majesty" (Allen 1984, 71). This honored position in creation entails, in part, having dominion (rule) over all other creatures that God has made (8:6-9), as well as greater value than all other created entities ${ }^{9}$ (Allen 1984, 71). This clearly hearkens back to the Genesis account. "There can be little doubt that David's poem is based on [Genesis 1:26-28]. To man, a creature of seeming insignificance, God has given great dignity ... Of all God's creatures; only man is made in his image. Man is the crown of the cosmos" (Allen 1984, 73). The anthropological framework through which we evaluate our application of biotechnology is the dignity of humanity as created in the image of God. A unique Christian bioethics stems from this central anthropological concept of humanity.

${ }^{9}$ I will briefly mention the relative worth of animals to humans due to its being a bioethical issue, especially in light of current militant animal rights activism over biomedical research using animals. Although remarkably passionate, this view actually threatens a biblical anthropology by asserting that animals are at least equal in worth to, if in not some cases of more value than, humans. The Story develops an anthropology in which individual humans are explicitly depicted as having "more value" to God than animals. Jesus makes this unequivocally clear when comparing humans to animals. He defends his works on the Sabbath day to the Pharisees by pointing out that if they would save a sheep fallen into a ditch on the Sabbath, then why not heal a man who is "of much more value" than a sheep. (Matthew 12:11-12) Similarly, He asserted that human life was more valuable than "many sparrows" and "the birds" (Luke 7:7,24). The clear teaching of Christ is that human beings need not worry about God's individual care because He values humans more than animals. In the Story God did not merely create humans distinct from the animals but definitely of greater value as well. Yet at the same time, God's charge to Adam to "tend" and to "keep" His good creation (2:15) has moral implications in how we treat animals. Jesus implicitly sanctioned rescuing an animal on the Sabbath in the passage cited above, indicating they are not devoid of value, and must be protected and not abused (Prov 12:10a) but that their value is subordinate to humanity's. 
The explicit New Testament application of man in the image of God adds a prohibition against the verbal degradation of humanity. James exhorts Christians that it is wrong to praise God and then curse (blaspheme) man with the same tongue. The anthropological grounding for this ethical instruction is that man is "made in the likeness of God" (Jam 3:8-10). In the biblical view, then, humans are to respect each other out of recognition that they are equally created in God's image. To assault a human, whether physically or verbally, is, ultimately, to assault God. Inversely, one's respect for God is, minimally, displayed in his or her respect for human life. This account does not exhaust this Story's anthropology, but it does represent its core. ${ }^{10}$

The concept of the image of God in Genesis 1, while definitive for human nature, may be interpreted from three different perspectives; substantial, relational and functional (LCWE 2005, 9).

The substantial view of the image has a long history in Christian theology while the relational view is perhaps more prominent now. These two categories correspond roughly to the two different kinds of "image" one can picture. The first is the one inscribed upon an object, such as the sovereign's image on a coin. The other is the more intangible kind one sees in a mirror. A third category views the image as functional and holds that the image of God is found in the exercise of "dominion" and "stewardship" of the rest of creation (Genesis 1:28). (LCWE 2005, 9 emphasis theirs)

The LCWE points out that not one, but all three of these views help us to explain the image of God in humanity, and that we present an impoverished view if we emphasize one over the other. Another way to frame the idea of image is as status and standard (Mitchell et al. 2007).

10

For fuller articulations of a biblical anthropology see Allen (1984), Hoekema (1986) the Lausanne Occasional Paper 58 (2005) and Mitchell et al. (2007). 
The substantial/status understanding of image conceives of humans universally as God's image bearers endowed with inestimable worth by virtue of their creation alone. The prohibitions of murder (Gen 9:6) and verbal disparagement (Jam 3:9) considered above explicitly tie into this worth. These instructions have tremendous impact on the way we should think about biotech applications and what we should do to uphold human dignity not only in our churches, but also in our society and throughout the world. Cameron clarifies the significance of the imago Dei in this universal sense when he points out that the image is "species specific" (Cameron 2001, 172). That is, "it is not to be found other than in humankind, and neither is humankind to be found without the image" (Cameron 2001, 177 emphasis mine). The very constitution of humanity is its bearing of the image of God. Wherever "human" is found,- - whether in the womb, Petri dish or in a comatose state - there is the image of God. "There can be no such thing as a human being who lacks the image, any more than a non-human who bears it. The image of God is borne by all, however irreligious or immoral they may be; or however deficient, disabled, sick, young or old" (Cameron 2001, 173). It is the doctrine of our "common humanity and of its uncommon dignity ... the image of God ... [which] is to be found wherever humans are found" (Cameron 2001, 173).

To speak only substantially, or ontologically, of the image of God, however, means we miss important insights about how humans can and should achieve the image, particularly in the process of sanctification. This element points to "the image as a future possibility" just as much as a present reality (LCWE 2005, 10). The believer grows in likeness to God through his or her relationship to Christ (Rom 8:29, 2 Cor 3:18, Col 3:10), so 
this is a dynamic experience tied closely with our redemption; not merely our creation but also our re-creation (LCWE 2005, Mitchell et al. 2007). "The image is a destiny, a direction, a destination rather than merely a statement about our origin" (LCWE 2005, 10). The functional view entails what God created humans to do, viz. "have dominion" and the image is manifest in the exercise of this dominion and "stewardship" (LCWE 2005, 9). To image the Creator is a vocation and a challenge, setting a standard for the moral life as well. ${ }^{11}$

By way of appraisal we have to realize that not one, but all of these views are important elements for understanding the imago Dei in humanity, and the emphasis of one over the other will not only distort our anthropology, but also our bioethics. As stated, if God created humanity in His image, as the Story asserts, then where we have human, we have the image of God. If we do not emphasize this, we could easily fall into the secular view of the bifurcation of the concepts of "personhood" from human biological life. That is, if we allow the dynamic/relational and functional or image as standard aspects to define our humanity, this could lead not only to the marginalization but even justify the eradication of those biologically alive humans who do not fit said criteria. On the other hand, if we only speak of the substantial/status side of the imago Dei, we could become complacent and fail to speak of how imaging God means to imitate God in the world as His representatives and in our relationships with one another. From this perspective we are to "become in practice who [we] already are in being" (Mitchell et al. 2007, 75).

Our present concern is how this Story conveys the important insight that God created humans in His image, not how. It is important to note that the biblical narrative never

11 This idea of imitation as imaging will be explored in more detail below. There is most clearly a dynamic/relational element to the imago Dei that we must not ignore. 
gives any details as to what exactly it means to be created in God's image. We should acknowledge a definite wisdom in this. God invested human life with such dignity as to warrant unconditional respect from all others. Humans, alone, are created in God's image, not because they can do anything, (e.g. have dominion, consciously relate to their creator, etc.) but because they are humans. If the idea of image was biblically articulated in terms of criteria-like the ability to create, reason, think, communicate, love or contribute-then some humans, we would have to conclude, do not display these functional abilities. They may not have developed them yet, as in the case of embryonic and fetal humans, may never have them like the severely mentally disabled, or they may have lost them through injury, aging or a disease process. What this would mean is that one could be human without being a person (an entity worthy of legal protections), which is exactly the conclusion Singer thinks we ought to have in view of current challenges in biotechnology.

When the traditional ethic of the sanctity of human life is proven indefensible at both the beginning and end of life, a new ethic will replace it. It will recognize that the concept of a person is distinct from that of a member of the species Homo Sapiens, and that it is personhood, not species membership, that is most significant in determining when it is wrong to end a life. We will understand that even if the life of a human organism begins at conception, the life of a person - that is, at a minimum, a being with some level of self-awareness—does not begin so early. (Singer 2005)

A wide-scale appropriation of Singer's bifurcation of mere "species membership" from the dignity of personhood on conditions of self-awareness immediately threatens the embryonic, comatose and the disabled elderly among us. In counter to this, Cameron's substantial, "species specific" account of the imago Dei serves as a safeguard to human persons regardless of their stage of development, or their ability to function in ways that humans are "supposed" to function. Likewise, the LCWE sees this substantial view of 
the image as "over against" a secular bioethics that emphasizes criteria, capacities and qualities, and which "affirms that all humans bear the image simply as humans" $(2005,11)$. Further, the LCWE also refers to the relational aspect of God's image, from the perspective of this Story, as protecting "the demented and severely intellectually disabled . . . [because they] can be known and loved by others and are so by God, so that they are indeed 'in relationship' by virtue of being human" (2005, 10-11 emphasis mine). All of us who own this particular Story, should readily agree with Cameron who states, “The church of Jesus Christ must be informed and it must speak soft, loud, in season and out of season, the words imago Dei” (Cameron, 2000, 79).

Embodiment. Another critical factor of the Story of creation is that God made humans as embodied selves (Verhey 2003, Wheeler 1996). Of first importance here is that we acknowledge our dependency. "Whole selves, embodied selves, are 'flesh' in their contrast to God and in their dependence upon God, in their creatureliness, in their weakness and mortality" (Verhey 2003, 164). Even in our unfallen state, we are still created, or "finite and wholly contingent," beings (Wheeler 1996, 22). We do not have life in ourselves, we are dependent on God, in whose hand is everyone's breath, and Who, if He so willed, could withdraw His spirit and put an end to us (Job 12:10, 33:4, 34:14-15); a sobering reality.

Secondly, we can appreciate that this Story presents a holistic approach to human existence. According to the Lausanne Committee for World Evangelization,

Secular bioethics often presents a narrow biological view of health and an instrumental view of human life, such that human beings who have limited capacities are assigned a lesser value. This outlook seems to leave little space for the psychological and social dimensions of human life, let alone its spiritual dimension. (LCWE 2005, 7) 
In direct counter to this, a distinctly Christian bioethics inherently affirms the equal and unconditional worth of all people, and maintains the spiritual dimension of human nature (LCWE 2005). A holistic biblical anthropology takes seriously that God made humanity from the dust of the earth (the physical), and breathed into him the breath of life (the spiritual), and man became a living being (a physical body energized by a spiritual endowment from God). "Because we are whole beings, God's concern and purposes for us are not limited to any one aspect of our existence, such as 'the immortal soul' to the exclusion of the physical body. Instead each of us is the recipient of God's love and is responsible before God in the totality of our embodied existence” (Grenz 1997, 264). Biblical medicine and bioethics neglects neither the material/physical nor the immaterial/spiritual dimensions of human existence but treats the whole person. We must reject any reductionism that defines "human" in terms of a body or material entity alone, and we must not neglect the body in care of the spirit.

Finally, our embodiment also is an important part of the Story because God takes pleasure in the human body. He created it and it is part of His "very good" creation, He made it the means through which we would image Him in a relational and functional sense, and also designed procreation to generate more embodied image bearers (Genesis 4:1, 5:3). Consistent with the Story, Christian bioethics affirms the value of the body insofar as it is God's deliberate creation. And insofar as God, in the great mystery of the Incarnation, assumed a body of flesh, beginning in the womb just like all of us, He sanctified human embodiment from the moment of its conception. In His embodiment, Christ healed diseased and raised dead human bodies, setting further precedent for valuing and healing the human 
body; the whole enterprise of medicine. Jesus' body was broken and bled, and, after death, Jesus rose again from the dead in a body, promising His followers that "as I live, you will also live" (John 14:19). The promise of the resurrection of the body is integral to the Story, and this further affirms the value of human embodiment and the goodness of medicine that seeks to restore embodied people to health.

Technology and the Cultural Mandate. Christian theists speak of a "cultural mandate," which has largely to do with our being given "dominion," and being charged to “subdue” God's very good creation (Gen 1:26). The former concept means literally "to tread upon" (implying superiority) or "rule" and the latter to "subject" or "bring under bondage." David, owning this Story, adds to the lexicon and speaks of humanity being given "dominion" as well, but the term he uses implies "governorship," over the rest of creation (Ps 8:5-8). This mandate came to humanity before the fall and suggests that humanity has a sovereignty, or rule, over the rest of creation which entails, in part, the harnessing of its resources to enhance human life. Hoekema suggests,

Man is called by God to develop all the potentialities found in nature and in humankind as a whole. He must seek to develop not only agriculture, horticulture, and animal husbandry, but also science, technology and art. In other words, we have here what is often called the cultural mandate: the command to develop a Godglorifying culture. (Hoekema 1996, 79)

"God set human beings in the midst of creation to be a sign of God's own rule," according to Verhey, and “they signal God's rule by their very physical presence and, of course, by ruling 
.. . To be God's 'image' is to receive a vocation to image God's rule, to imitate God" (Verhey 2003, 161). $^{12}$

This implies the goodness of technology; in fact, one might say that inherent to a biblical anthropology is that God created humans to be essentially technological. Technology is the process by which a society uses applied knowledge (science) to provide its members with needs and desires. Even if humanity had not fallen, one could easily see how the invention of such things as the wheel, the yoke and plow, irrigation systems, farming, textiles, petroleum processing, hydraulics, etc., would have come to be. In essence, technology raises us above the natural limits imposed by creation, and God's giving humanity this "dominion," and this charge to "subdue" it, suggests the authority to do so. This "rule," "sovereignty," and "governorship" however is not a blank check for the careless and selfish exploitation of the natural resources. The Story also states that humans were placed as those who would "serve" and "preserve" or protect the creation as well (Gen 2:15). Commenting on this text Hoekema asserts,

It is important, however, to note, that the proper relationship of man to nature is not simply that of ruling over it . . If human beings had been commanded only to rule over the earth, this command might easily have been misconstrued as an open invitation to irresponsible exploitation of earth's resources. But the injunction to work and take care of the Garden of Eden implies that we are to serve and preserve the earth as well. (Hoekema 1996, 79)

Thus, there is a balance between being mini-sovereigns over creation and its stewards who manage and care for the master's property, consistent with the way the master

12 Here, of course, the emphasis is upon image as standard, or image in its functional/dynamic sense. 
would do it Himself. ${ }^{13}$ With this in mind, the cultural mandate calls upon us to develop a God-honoring culture, to develop technology that helps us live fuller lives in creation by harnessing the power of the natural resources around us, but not carelessly to exploit those resources while doing so.

In light of this grand perspective, the development of technology, including biotechnology, is essentially good. Of course, biotechnology, and biomedicine, has become necessary because of the introduction of dying and death and all that accompany the curse due to the corruption, but we do see that God himself, in miracle, heals the blind, the deaf, the mute, the lame and various diseases. He also opens the barren womb. In view of this, Verhey provides a balanced biblical bioethics with regard to biotechnology.

It will hardly do to adopt a casual anti-technological spirit . . . [this] would [require that] we regard respirators, dialysis machines, insulin, and penicillin illicit . . . it is slothful to suppress and refuse the dominion that has been given to humanity as a mandate and a blessing. The question should not be whether human beings will "play God" or not - God settled that issue by making us image bearers and stewards. The question should rather be whether or not persons are exercising their God-given dominion responsibly. It would be moral sloth and folly to reject medical technologies, including reproductive technologies, simply because they interfere with natural processes. (Verhey 2003, 286)

Post-fall, it would seem that any use of technology to heal as God does by miracle; causing the deaf to hear, the blind to see, the lame to walk, the barren to procreate, etc. are open options and appropriate applications for human technology in keeping with the cultural mandate. Christians should, by virtue of the cultural mandate, and their technological

13

Psalm 104 depicts how the LORD actively sustains and nourishes his creation. Its beautiful language could definitely serve as a model for the care humans should have over the earth and its fellow inhabitants. A strong case for conservationism and earth care could be made insofar as it is imitating God's example. 
essence, be on the forefront of developing biotechnologies that improve human well-being, alleviate human suffering and preserve human life. The issue with all (bio)technology, as Verhey has indicated, becomes one of exercising our God-given dominion, that is our technological essence, "responsibly." This has always been the divine vocation for humanity, but has become an even greater challenge since humanity's Corruption.

\section{Corruption and Bioethics}

The Corruption part of the Story comes early. "Almost in the same breath [as we are told we are created by His good pleasure], we discover ourselves as sinners, rebelling ... against the very gift of our being, seeking to be our own gods and to set the terms of our existence without constraint" (Wheeler 1996, 22). "Corrupt" indicates to "break, destroy or spoil" (Websters New World Dictionary and Thesaurus 1990-2000, s.v. "corrupt”). At the moment of original sin, brokenness was set in motion throughout God's "very good" creation. This part of the Story has many important implications for our bioethics.

Death and Depravity. The immediate consequence of disobedience for all humanity was death and the dying process. "On the day you eat of it, you will surely die" (Gen 2:17). The construction is an infinitive absolute with a repetition of the word "die." The infinitive absolute places an emphasis on the verbal idea; thus "to die, you will die." Not just death, but the whole dying process began. We find this to be the case when God pronounces the curse upon humanity; "for dust you are and to dust you will return" (Gen $3: 19 b)$. Death is the physical aspect of our corruption.

Paul owns this Story and asserts that death "entered the world and passed to all men" as a result of Adam's sin (Rom 5:12). With this came all death's accompaniments 
as well; disease, degeneration, decay and the dying process. These were not present in God's "very good" creation, and, according to the Story, they will not be present in His new creation either ( $\operatorname{Rev} 21: 4)$. Until then, we will witness and personally experience disease, decay, dying and death in a world rife with "groaning" and "futility" in the "bondage of corruption" (Rom 8:20-22). Indeed the curse was that "In the sweat of your face you will eat bread until you return to the ground [in death]" (Gen 3:19a, cf. Eccl 12:7). This was the curse, the condemnation that followed the original corruption, and "the curse fell heavy on God's good creation ... on the ground ... it reached into the womb ... it reached into our sexuality ... it reached into our sociality ... the curse fell ... on the whole creation" (Verhey 2003, 171).

Paul sheds further light on the Story. "By one man sin entered into the world and ... all have sinned" (Rom 5:12). From that defining moment in the Story the world has been set on a course characterized by individuals that defy God's rule in an effort to establish their own (Hauerwas 1989). Depravity is the moral aspect of our corruption.

In this Story, an enemy, Satan, ${ }^{14}$ takes an active role in seducing humanity to grasp for godhood. This enemy still attacks humanity the way he did in the first temptation; by the seductive suggestion to grasp for God's place and prerogative. ${ }^{15}$ At the heart of the

${ }^{14}$ Although the account in Genesis 3 does not mention Satan, it seems clear that Satan was behind this original temptation based on later references in John 8:44, 2 Cor 11:3, 1 John 3:8 and especially Rev 20:2 where Satan is called "the dragon, the serpent of old ... the Devil and Satan."

15 The original, and continuing, temptation of humanity in fact stems from Satan's own attempt to usurp God's authority and dominion. Isaiah 14 is the classic text 
first and every subsequent temptation is the suggestion to be our own god, knowing good and evil for ourselves, declaring our independence and autonomy, establishing our own dominion, law and authority rather than accepting His. According to Eyer, in this part of the Story we discover "the source of the tension in today's discussion of moral issues in bioethics" (Eyer 2000, 56). Since this moment in the Story, "human beings [have been] engaged over the question, Who shall be God—God or man? Who therefore shall distinguish good from evil—God or man" (Eyer 2000, 57)? The essence of sin is the lust for an unbridled autonomy, a grasping for godhood; the divine prerogative to determine right and wrong for ourselves.

Satan also seduced Eve with the idea that God had lied to her-"You will not surely die" (Gen 3:4)-and listening to the liar will eventually lead us to believe that God is the liar, engendering mistrust of God (Imrenyi 2005, 3). Not only had God deceived her, but he was depriving her and her husband, keeping something back from them that would be of great benefit, a source of pleasure and fulfillment, namely godhood (Gen 3:5). Every subsequent temptation also has, at its root, an attempt to make us feel as though God has deceived us and is depriving us of something that would really make us truly happy and fulfilled beings.

Both physical and moral corruption have been set in motion in God's creation, and both have been passed onto every child ever born. David owned this Story when he declared, "behold I was brought forth in iniquity, and in sin my mother conceived me" (Ps

where Lucifer's fall is recorded. His desire for autonomy, self-determination and selfexaltation resulted in his being cast down. If this is not a direct reference to Satan's origin, it certainly is illustrative of it. 
51:5). Both the physical and moral dimensions of our corruption are witnessed in the first sin recorded following the fall and curse. Cain, moved by his depravity murdered his own brother, Abel, who died a bloody death (Gen 4:8). Depravity and death have permeated the human experience and are the essence of the corruption in God's good creation.

Disillusionment, Despair and Delusion. As we experience and witness degenerating bodies and are exposed to the diseased and dying around us, and as we see a broken world filled with natural calamities (Rom 8:20-22) and violence the emotional reaction to all of this is often disillusionment and despair. Further, as we repeatedly hear of human depravity manifested in man's inhumanity to fellow man, it is easy to become overwhelmed with a sense of helplessness and hopelessness that there can or will be any good.

In all of this "human condition," however, our depraved quest for godhood continues. In fact, Satan masterfully puts in our heads that God is still depriving us of good things, and deludes us into thinking we can devise technologies to overcome our deplorable state, to fully reverse the degeneration and even conquer death. This is where the Corruption part of the story connects with biotechnology. Such ability feeds the idea that we be our own gods and take control over our own lives. We feel that we can somehow save ourselves from the physical and moral corruption through our medical technology.

This is why Christians must understand the Story. Modern biotech can be the forbidden fruit that, if grasped, can lead to our further undoing. The fallout from the Fall came as a consequence of divine judgment, and cannot ultimately be reversed by sheer human effort (technology). In our state of "futility" and "bondage to corruption" we yearn 
for the final redemption, when "the whole creation will be delivered ... into the glorious liberty of the children of God" (Rom 8:21-22). Until then we must identify and accept the limits our corrupt state places on us and admit that only the One who did the cursing can finally reverse the curse.

Depravity and Dignity. It is important to state the reality and pervasiveness of our depravity does not eradicate our dignity. That is, our failure to meet the standard of imaging God, does not erase our status as His images (Mitchell et al. 2007). This point can be proven by considering how, despite the post-flood fact that "the imagination of man's heart is evil from his youth" (Gen 8:21), God reiterates, in the same breath, that humans are still made "in the image of God" (Gen 9:6). David proclaims that man is "crowned with glory and majesty" (Psalm 8:5) but also "corrupt [and there are] none who do good, no not one" (Psalm 14:3). James speaks of humanity as "made in the likeness of God" (James 3:9), while at the same time capable of "bitter envy and self-seeking" (3:14); in fact, "every evil thing' (3:16). All this clearly affirms that, although corrupted, humanity's dignity (the image of God), is not cancelled; although distorted, it is not destroyed. In fact, there are those who argue that the effects of the Fall—corruption and distortion—on the image of God in no way touched the image as status, but only in the sense of standard. "Those created with the status of God's image no longer measure up to the standard of what God's image should look like—even though they retain the status" (Mitchell et al. 2007, 74). This is an important insight in that it holds that the status of human dignity is intact, despite the Fall and regardless of whether a given human lives up to the standard, and should consequently be treated with the respect that human dignity demands. Nevertheless, Paul says we need to be 
"renewed in knowledge according to the image of Him who created him" (Col 3:10). The implication here is that this cognitive renewal of the awareness and living up to the standard of our inherent dignity is a part of the sanctification process.

It is also important to reiterate that while our being technological has its roots in our created dignity, it is not unaffected by our pervasive depravity (Jer 17:9; Rom 3:10-23) and that "the nature of human rebellion ... extends into all human cultural enterprises, including science and medicine" (LCWE 2005, 11). Consequently, we live in a continual tension as to how to apply technology. This application can be born of either our dignity or depravity, or a complex mixture of both. For example, God told Noah a "righteous" man, to "build an ark" which was a feat of great technology (Gen 6:14). Later, humans decided to build a tower to reach to the heavens, also an incredible technological endeavor, but this technological application was contrary to God's will (Gen 11:3-4). There is no moral difference, per se, between building a boat and building a tower. At issue is the motive for which one is doing so. Certainly, the satanic impulse-grasping for godhood-was the impetus for the tower of Babel, and thus a technological display born of depravity. Submission to God's authority drove the building of the ark and was thus consistent with the cultural mandate to exercise dominion; a technological application born of dignity.

In light of this tension, we must be vigilant to apply our (bio)technology in a way that consists with and upholds the dignity of all. We cannot ignore the creational worth of some humans in order to restore or enhance the health or happiness of others. "It is ... an imprudent thing to try to heal a less important physical disease by committing a sin that infects us with a truly and eternally spiritual disease. Man as created in the image and 
likeness of God is called to be a healer during this life too, but this does not extend to doubtful (or even heinous) means" (Imrenyi 2005, 5).

Coming to terms with both our dignity and depravity will lead us to say, with Paul, "I know that in me, that is in my flesh [corrupt nature] nothing good dwells" (Rom 7:18), and thus "when I would do good, evil is present with me" (Rom 7:21). Evil always lurks at the door of every human endeavor, no matter how "good." This caveat comes from being realistic about our depravity. This realism should lead us to pause before applying any given biotechnology to make sure that we are not, in fact building the tower rather than the ark. $^{16}$

Covenant and Bioethics

Covenant is the motif of the story where we discover that God has not given up on sinful humanity leaving us to die in depravity and despair. God's willingness to make covenant is the basis of humanity's hope because it means that God has not, will not, let death and depravity have the final word. Covenant, in essence, is God's redemptive reach to restore fallen and corrupt humankind to a place of communion with Him.

16 Christians, and especially our young people, must not be made to think that the church is anti-technology or Luddite; far from it. Technology, rather, must be understood as a part of our creation mandate to "have dominion," but must be used to shape and build a culture that glorifies God. A secular emphasis in technology allows that "can" implies "should," but Christians seeking to honor God cannot take such a view. In sharp contrast, biblical morality, centered on the sanctity and dignity of human life created in God's image and likeness, must limit technology. The fact that the application of this limitation is hardly ever easy to discern must not prevent us from grappling together in the process of that discernment. If anything, it should create a sense of pause to really deliberate and discuss how to apply biotechnologies within the limits before rushing in, like fools, to use them without restraint. 
According to the Story, God simply wants to dwell with and fellowship with His human creation. This is seen in the earliest parts of the Story, where God creates beings in His image who can relate to Him, and with whom He "walks" (Gen 3:8). After the corruption, God's passion to dwell with His people does not diminish but it does become more complicated. His holiness precludes dwelling with sinful and fallen humanity. We must not forget that this Story is about the God who "takes [no] pleasure in wickedness, nor will evil dwell with [Him]" (Ps 5:4). Establishing covenants with fallen humans is His chosen way to continue "dwelling" with us. This dwelling with His people as their God is so valuable to God, and the Story shows us that He will go to great extremes to maintain that relationship. The concept of "covenant" appears in relation to God's devising and implementing specific arrangements to dwell with a corrupt and sinful people. As the Story is told, we find God is always the loving and gracious initiator of covenant, and the One who establishes the criteria and conditions necessary for sinful humanity to be in relationship with Him in His holiness. This concept summarizes the biblical view of God and humankind in relationship.

The word is first used in the Story in relation to Noah. God promised to establish a covenant with Noah, and this promise follows the dismal description of widespread human corruption (Gen 6: 6-7, 11-12). It next appears in the Story when God calls Abraham (Gen 12:1-3, 15:7-18, 17:7). In this second explicit mention of covenant, there is a clear and definitive goal, to "bless" "all the families of the earth" (Gen 12:1-3). Not surprisingly, because of its cosmopolitan scope and reach, this covenant with Abraham 
becomes an underlying and unifying theme throughout the rest of the Story, extending all the way to Christ (Rom 4; Gal 3:6-29).

The covenant promise is that of divine presence with humanity in a special relationship; "I will be their God and they will be my people." This language is used by Moses to show that the legacy of the covenant God began with Abraham passed on to Isaac and Jacob and on to the nation of Israel (Gen 17:7-8; Lev 26:11-12, 45-46). We also find this language of covenant when David calls his subjects to "remember His covenant," "His oath" and "everlasting covenant" to Abraham, Isaac, Jacob and Israel (1 Chr 16:15-17), clarifying that the Story of this covenant was their story as well!

Important to this Covenant motif are two things that point to the centerpiece of God's big Story; Christ. The two elements are the "new" covenant promised to Israel prior to their Babylonian exile (Jer 31:31-33), and the special language of covenant where God purposes and promises that He will be God to His people and they will be His people (Gen 17:7; Lev 26:12; Jer 31:33, 32:38; Ezek 37:23). These two key elements tie the whole story together and are brought to their fullness in Christ, which we will consider in detail below.

If covenant is God's loving and gracious reach to redeem a corrupt humanity, redemption and covenant is the part of the Story which tells us that God is bringing beauty out of brokenness, and transforming tragedy into triumph. This is our hope in the midst of our corruption; our depravity, death and all their accompaniments. This is the context for us, as the church, to approach our bioethical challenges, and live to see beauty emerging even in the midst of our brokenness. It is an invitation to relate with God as our Creator and Father, 
and, according to our original created purpose, to image our God, and manage His creation as faithful stewards. To enter personally into covenant requires an ownership of the brokenness of our corruption, and a grateful acceptance of the covenant price ultimately paid by Jesus Christ in His death on our behalf.

The covenant motif has significant bearing on our bioethics in that it places us into a relationship with our Creator that serves as our basis for understanding, appreciating and owning the Story and its implications for our lives and bioethics. As we grow as His covenant people, He increasingly renews us in knowledge of what it means to be His created beings, which has bearing on our identity and purpose in this world (Col 3:11). This provides us with the basis for affirming human dignity as a guiding principle for our bioethics in that it reminds us and renews us with the knowledge of our status as His image. All people, regardless of whether they meet up to the ethical standard to which God calls us, have dignity and worth that must be affirmed and honored in every bioethical decision we make. "Human beings retain their full status as images of God ... [and] the ethical standard of respect for human dignity gains its force precisely from this" (Mitchell et al. 2007, 74). In fact, Christians, those rightly related to God through Christ, are said to be being renewed in the image of their Creator, and this should make us more "adept at being ... the image of God ... [and] more likely to excel at recognizing the image of God in others and treating them appropriately" (Mitchell et al. 2007, 75). The covenant motif also shows us how important and valuable the divinely created, embodied human being, the object of medicine, really is. It also provides us the moral model for our own actions and decisions; not only in the God of Israel, but God in Christ, whose imitators we are to be (Eph 5:1-2). Being in this 
covenant relationship with God through Christ, also points us to the end of the Story, which not only fills us with hope, but also serves as an important framework for how we perceive the place and limits of biotechnology in our experience.

\section{Consummation and Bioethics}

Biotechnology and bioethics automatically draw our attention to suffering, and thus frequently and painfully remind us of our brokenness in this world. Biotech has to do, largely, with trying to heal the brokenness, and cannot always do so. One might ask how the biblical Story has anything to do with ours when we experience the inability to conceive, the severe deformity or death of our offspring, or when loved ones, or we, end up in car accidents and comas, lose memory and a sense of identity due to Alzheimer's, receive the dreaded cancer diagnosis, or are being artificially fed and hydrated through tubes with our lives hanging on a thread. The Consummation of the Story answers these concerns.

The Story of Creation, and our still bearing His image despite our corruption (Gen 9:6; Jam 3:9), is a continual reminder that we matter to God, and that we should matter to each other. The story of Corruption accounts for why we suffer as we do. It explains the origin of disease, dying and death, and helps us come to terms with their inevitability. It also reminds us that we do have sinful propensities due to our depravity and thus limits us in our application of biotechnology. The story of Covenant tells us God still cares to have a relationship with us in the midst of our corruption and will not let death and depravity have the last word. Covenant looks back and forward at the same time. In the midst of corruption, God establishes covenants with sinful people and reminds them of their created dignity and worth to Him, which involves a restored communion with their Creator, but this promise of 
communion finally anticipates the reversal of the curse and the restoration of communion at the highest level in the new heaven and new earth. Consummation, then, is the part of the Story best summed up in John's prophetic vision:

Now I saw a new heaven and a new earth, for the first heaven and the first earth had passed away. . . Then I, John, saw the holy city, New Jerusalem, coming down out of heaven from God ... And I heard a loud voice from heaven saying, "Behold, the tabernacle of God is with men, and He will dwell with them, and they shall be His people. God Himself will be with them and be their God. And God will wipe away every tear from their eyes; there shall be no more death, nor sorrow, nor crying. There shall be no more pain, for the former things have passed away." (Rev 21:1-4)

The "former things" are all that characterize our state of corruption that issue in the "tears ... sorrow ... crying ... [and] pain" of the present human condition. The covenant promise that "I will be their God and they will by my people" looks forward, as we see, to the final restoration when God promises that "He will dwell with them, and they shall be His people" $(\operatorname{Rev} 21: 3)$.

It is no small matter that the Story tells us, "the tree of life," from which humanity has been banished since the Fall when corruption entered God's good creation, will be present and available in the New Jerusalem, the Holy City of God and this tree's fruits will be "for the healing of the nations" (Rev 22:2)! This fulfills God's covenant with Abraham that in Him, and ultimately through His descendants through whom came the Christ, "all the families of the earth will be blessed." The original covenant with Abraham will come to final fruition, and the nations will be "healed!"

The vision of the Consummation is a vision of final healing, a removal of the corruption, death and decay that defiled the beauty of God's very good creation, disrupted the fellowship God's image bearers had with Him, and made medicine necessary in the first 
place. This fellowship will finally be restored by the healing presence of God. This is the part of the Story that Paul anticipated when he wrote about the suffering and affliction of being in the temporary, groaning world. Rather, those who belong to God eagerly wait to be "delivered from the bondage of corruption into the glorious liberty of the children of God" and "the redemption of our body" (Rom 8:21, 23).

These observations have important implications for our bioethics.

In anticipation of the coming consummation . . . believers are called to work at their various vocations in a redemptive way, using their skills to bend back the effects of the Fall toward their created goodness. In this manner, the physician will imitate the Lord Jesus through acts of healing; not necessarily through miracles, but through genuine acts of compassion and the application of God-given skill. (Blocher, 2005, 4)

Blocher also writes, “As God's covenant people we are called to live redemptive lives. We are to bend back toward the good whatever has been tainted by sin and corruption" $(2005,4)$. As we have seen, Jesus' healing ministry set a precedent for our use of medicine to, in Blocher's words, "bend back the effects of the Fall toward their created goodness." But each healing also was a symbolic pointer to the final healing and redemption of the consummation. Song points out, in fact, the close relatedness of the words "heal" and "save."

For Christians, the practice of medicine is understood in the category of healing, which is itself viewed in relation to salvation in Jesus Christ. The precise relation of salvation and healing is of central importance: the former cannot be reduced to the latter (which would render the goal of health all encompassing and so idolatrous), nor would the latter to the former (which would make salvation an other-worldly event without significance of life in this world). The relation between salvation and healing is best understood analogically ... just as symptoms relate to a disease, so physical illness is a manifestation of the underlying cosmic disorder brought about by sin; likewise in Christian ministry of healing, works of healing can symbolize salvation, both showing what it is like and embodying some of its reality. This intimate link between the two explains why salvation and healing are so closely linked in the New 
Testament - the word soteria is used for both. Jesus' power to forgive sins is connected to His healing ministry (Mark 2.1-12). (Song 2005, 338 emphasis mine)

Every time we are "healed" of anything that ails us, whether the common cold or cancer, these events anticipate this final redemption, and the ultimate healing. It anticipates a New Heaven and a New Earth where there will be no more pain, sorrow, suffering, or death; final and full salvation from corruption, where every tear will be wiped from our eyes because of God's healing presence ( $\operatorname{Rev} 21: 1,3-4$, cf. 7:17). Every healing is a reminder of this certain future for God's covenant people.

But we must also stress, that as far as bioethics is concerned, this final healing of the nations, deliverance from the bondage of corruption and redemption of the body, is indeed our future, it is not the present. As we saw above, the corruption of humanity will not, cannot, finally be reversed except by God. All we can hope to do is "bend back the effects of the Fall toward their created goodness" (Blocher 2005, 4). Researchers, doctors and health care professionals can work with all their God-given might and skills to follow Jesus' example and seek to heal embodied persons, and sometimes they will. But often, and perhaps more often, they will not. The final healing will not come until the consummation of all things.

In this knowledge doctors can actually rest and lay aside any messianic delusions or false expectations they hold for themselves or their medical technique to eliminate suffering altogether. In light of our corruption and the consummation, biblical medicine, seeing medicine as a care-giving ministry not a cure-all messiah, "will be less tempted to triumphalism, to the expectation of a technical solution to human mortality and vulnerability to suffering. ... such a medicine will sustain and nurture truthfulness about our 
finitude ... it will sustain and nurture humility, the readiness to acknowledge we are not gods" (Verhey 2003, 328). "The stories of Jesus teach physicians to delight in their tools as gifts of God, to celebrate scientific advances for the powers they give to intervene in the sad stories patients tell with and of their bodies. But these stories also correct those who have mistaken technology for the savior" (Verhey 2003, 329). In this Story it is significant that Jesus, although he could have, did not heal every sick person. Further, even as a person of the Covenant, Paul was not healed from his "thorn in the flesh," that is, not finally delivered from the physical consequences of the Corruption, nor did he heal all others (2 Tim 4:20).

The same holds true of people seeking treatments for their ailments, however mild or severe. The reality of our corruption and the limits of medical technology to reverse it should help patients relinquish any undue expectations they might place on researchers, physicians and health-care providers to be medical messiahs. Medicine is, in large part, a response to death and its precursors. A biblical understanding of it is that it "bends back" the effects of the Fall, but cannot bring them back to their created, or forward to their consummated, goodness. A biblical view of medicine will not place hope in technology, but rather acknowledge that there will always be a "time to die" (Eccl 3:2) and a time to face all that death and dying entail, no matter what a secularly driven technology promises in terms of improving our life's quality or extending our longevity. In short, biblical medicine does not look to biotechnology to give us ultimate power over our corruption and its consequences, and a biblical bioethics teaches this. 
Christ and Bioethics

Placing the discussion of Christ at this point is not meant in any way to detract from His prominence. In fact, the biblical metanarrative is a Christocentric Story. His work and ministry is the culmination of the Covenant work of God, as seen above, in terms of the New Covenant that ultimately looks for the new heaven and new earth in the Consummation.

Christ and Covenant. As alluded to above, God promised Israel that $\mathrm{He}$ would establish a "new covenant" with His people, and Jesus explicitly and overtly connects Himself with this "new covenant" while eating that last Passover with His disciples before His death (Matt 26:26; Mark 14:24; Luke 22:20; 1 Cor 11:25). At this quiet moment, in a private upper room in Jerusalem, Jesus deliberately and decisively tied all that He was doing into the Story of all that God had been doing to dwell with fallen humanity from the time of Adam's disobedience (Gen 3:15), and through Abraham (Gen 17:7-8), Moses and Israel (Lev 26:11-12, 45-46) and finally David (1 Chr 16:15-17). He was announcing that what God intended to do through the new covenant as promised through Jeremiah (31:31-33), He, Jesus Christ, through His shed blood (His complete work on the cross) would inaugurate! Hebrews was written to definitively show the relationship and contrast between the old and new covenants, arguing that Jesus is "the Mediator of the new covenant" (8:6, 9:15, 12:24), and the consummation of all God's covenanting with sinful humanity. That Jesus is the fulfillment of the new covenant is unequivocally clear (Heb 8:6-12 is a direct quote of Jer $31: 31-34)$

Jesus' centrality to God's big Story is emphasized in the special language we find in God's covenant promises. As mentioned, the relational language of covenant is along 
the lines of "I will be their God and they will be my people" (Gen. 17:7; Lev 26:12; Jer 31:33, 32:38; Ezek 37:23). Though not as frequently, we still do find it in the New Testament (2 Cor 6:16, 18; Heb 8:10; Rev 21:3). Especially significant, along with this language, is the specific description of God's promise to dwell with His people in a tabernacle or temple; "I will set my tabernacle among you ... to walk among you and be your God and you shall be my people" (Lev 26:11-12) is the essence of this covenantal promise. Anticipating the new covenant, Ezekiel (37:21-27) assures God's people that His "tabernacle also will be with them; indeed I will be their God and they shall be my people" (37:27). Paul understood this covenant language of God emphasizing His residence with His people to apply to the church. He writes, "You [or "we"] are the temple of the living God, as God has said, 'I will dwell among them and walk among them. I will be their God and they shall be my people"' (2 Cor 6:16, cf. Eph 2:20). Here, he could have been quoting any of the Old Testament passages mentioned, but is probably just capturing the theme of Holy Scripture which reveals the heart of a God bent on dwelling with His people. Finally, this same exact language of divine residence and relationship with His people appears at the end of the Story. In John's Revelation, as the New Jerusalem descends from Heaven to earth in the climax of the Story, a voice declares, "Behold, the tabernacle of God is with men, and $\mathrm{He}$ will dwell with them, and they shall be His people; God Himself will be with them and be their God" (Rev 21:3). We know that this presence is Christ in that "He who sits on the throne" identifies Himself as the "Alpha and Omega" (Rev 21:6, cf. 1:8, 17).

In reading about this Consummation we see that our Story is all about Christ, and finally makes sense only in Him. He is the agent of Creation, the active Word that 
creates (Gen 1, Psalm 33:6, John 1:1-3, Heb 1:2). It was about Him after the Corruption set in as the promised seed of the woman who would trample the enemy and reverse the effects of the curse (Gen 3:15). The whole Story is precisely about God's passion to dwell with, be with, and walk with, His people. It is the Story about the nations, "all the families of the earth," being blessed and coming into the family of fellowship with God through Jesus Christ (Rom 4:16-17a; Gal 3:16-17, 29). It is the Story about Emmanuel, God with us, and Jesus is the embodiment of this divine passion; the eternal Word made flesh and "dwelling" among us, displaying His glory (John 1:1, 14). The Story is about God seeking to dwell with His people, and Jesus is the Story; the beginning, the end and everything in between! This is exactly what he means when he declares at the Consummation, "It is done! I am the Alpha and the Omega, the Beginning and the End" (Rev 21:6). It is in Christ that all things, the beginning, the middle and the end of God's Story, all elements of cosmic and human history are "summed up" (Eph 1:10). Jesus was the central Person of the divine plan all along (1 Pet 1:20-21)! In His ministry on earth, Jesus was clearly self-aware that He was the point of the whole Story (John 5:39, Luke 24:44-45).

Jesus was possessed by the conviction that He was not only the subject, but the central subject, of prophecy-that men of God, speaking as they were moved by the Holy Ghost, had, all down the ages, been pointing to Him at once as the Consummator and the Consummation of the Divine purposes, not only as regards Israel, but also the world (Streatfield n.d., 134).

According to biblical revelation, there is no other way to understand the flow of history, and this history includes, as we will see, our stories as well. Ethics is about our living in coherence with the Story that is still unfolding since Christ has united us to it through His completed work. In His story our stories, with all our suffering, pain, and death; 
all our bioethical struggles and dilemmas, become intelligible. Christ is the moral model par excellence. We will explore how His actions and teachings in the Gospel inform our bioethical decisions in greater depth in part two.

Christ and Community. We must own this Story. That is what "faith" entails, but faith in this story necessarily has a communal dimension to it. We also own this Story together. "Faith is much more than giving credence, it is giving oneself to the God who is believed, and into the community created by what God in Jesus Christ has done for all in common" (Wheeler 1996, 20 emphasis mine). When we believe in, that is own, this Story, we not only receive restored fellowship with our Creator, and embark on the renewal of "the knowledge of the image of Him who created [us]" (Col 3:11)—a rediscovery of God's image as the standard for our moral lives—in a covenant relationship, but also the new fellowship of "the communion of saints," the community of all those—past and present—in covenant relationship with this God, and it is this covenant community that becomes the context for all of our ethics. Essential to the image of God as standard is the fact that we are renewed not as individuals only, but also as a community (Mitchell et al. 2007, 76). “The biblical ethic does not address itself to the individual in isolation. Instead, knowing that we constantly live in social contexts, we can only speak to persons-in-relationship. The biblical writers call us to live as God's people in all our relationships, and as a result, the Christian ethic is never merely a 'personal' but always a 'social' ethic" ${ }^{17}$ (Grenz 1997, 264).
17
An indispensable dynamic of the biblical motif of covenant is that God forms covenants with a people, not individuals. This communal aspect of the biblical narrative has implications for our bioethics as the church, the significance of which I will explore in great detail in the next section dealing with practical applications. 


\section{Part Two: The Practice of Bioethical Education in the Local Church}

Part one of this chapter provided a detailed, but by no means exhaustive, articulation of the Story. Nevertheless, what was discussed was essential to the task before us; to guide Christians into moral discernment in order to help them make decisions that are consistent with the Story they love. "Christians must learn ... how bioethics may take the form of a response to the action of God in Jesus Christ . . . they must learn how bioethics flows out of worship and is embodied in the life of the Church community" (Song 2005, 337). Song's assertion has two important elements to it, which have been the focus of this project. First, he calls attention to the "action of God in Jesus Christ" as that to which Christian bioethics is a response. By conceiving of the foundation for Christian bioethics as the Gospel of Christ, and the Story which provides a context for the Gospel-Creation, Corruption, Covenant, and Consummation-we can provide a framework which makes bioethical dialogue both intelligible and attainable within the congregation regardless of a given person's background or educational level. The other important element of Song's conclusion is that bioethics is "embodied in the life of the Church community." As hinted at above, God's work is always for and through "a people" not individuals. This community dynamic is indispensable to a truly biblical bioethics. We will now consider the importance of these two concepts of narrative and community for a genuinely biblical bioethics.

Community, Narrative and Ethics

A distinctively Christian bioethics does not begin with the articulation of a set of ethical norms but rather the embracing of a theological narrative. This notion is behind 
Wheeler's unequivocal statement that ethics is "a bad [even "wrong"] place to start" when it comes to bioethics (Wheeler 1996, 19).

The Christian community is not defined by those who behave in some particular way ... nor is it made up of those who hold some particular moral opinion or group of them, whether these be convictions about abortion . . . or about any of a range of other serious and important issues. Instead, the Christian church consists of those people who believe the things that Christians affirm, which are in the first instance not moral statements at all, but rather, affirmations about what God has done, not about what we must do. (Wheeler 1996, 19-20 emphasis hers)

\section{The Character and Force of Biblical Narrative Ethics}

Eyer holds that story "is a more basic and more enduring foundation on which to establish ethics" because it "gives coherent meaning to our life together" (Eyer 2000, 3738 emphasis mine). And the definitive "story" for the church, according to Eyer, is the Gospel. "As Christians we need not concern ourselves merely with what to do or not to do. Rather, we keep our eyes on what God has done ... and continues to do [the story], not primarily about what we do" (Eyer 2000, 69). Likewise, Hauerwas concludes, "The ethical significance of Christian convictions depends on the power of those convictions to shape a community. ... Christian social ethics should ... begin with the formation of a society shaped and informed by the truthful character of the God we find revealed in the stories of Israel and Jesus" (Hauerwas 1989, 92). According to Wenham, biblical ethics has always, from the formation of Israel reaching to the Church, had a "communal setting . . the biblical text with its didactic message is at once the product of a community and also designed to create and perpetuate a community" (Wenham 2000, 102).

The ethical substance of the Christian life eventually derives from this narrative of what God has done, is doing and is yet to do in human affairs. The first 
appropriate response is entering into a relationship with this God and joining the community formed by His Story. A community is, in part, a social unit that shares a common, formative story of some kind, but in the case of God's community, it is not merely characterized by a particular narrative, it is constituted by it (Verhey 2003). Christians must be taught that the church's ethical principles and positions are "clearly embodied in narratives, church practices and faith-community understandings," and that "rules and principles are not suspended in mid-air; they get their meaning and have their context in the realistic, embodied ... narrative of both Testaments" (Stassen and Gushee 2003, 117).

The covenant has behavioral consequences for those who are in its blessing. Although story is central to God's community, rather than ethics as such, the particular story has inevitable ethical consequences. "Ethics is not the starting point of Christian faith, and morality not its heart-but neither is the call to 'live a life worthy of the gospel' merely optional" (Wheeler 1996, 20-21). The people of the community constituted by this story, those who genuinely believe and embrace it as their own, will experience a transformation of conduct and character; and will be concerned, in light of that story, with what to do and what to leave undone (Verhey 2002 and 2003). "The community of faith is a moral community-a community of mutual discipline and mutual accountability-not incidentally, but essentially." (Wheeler 1996, 20 emphasis hers) The community formed and transformed by this narrative, or worldview, serves as the milieu for bioethical education in the local church.

A small biblical sampling of the significance of the formative and transformative nature of narrative for God's covenant community will suffice. After the exodus from Egypt, Moses'song reverberates with high theology rooted in story. 
Remembering what God did is how the Israelites know who God is. He is a "man of war," He is "my salvation," He is "my strength and song," (Exod 15:2-3), and all this because, "Pharaoh's chariots and his army He has cast into the sea; his chosen captains also are drowned in the Red Sea. The depths have covered them; they sank to the bottom like a stone" (Exod 15:4-5).

This concrete experience in history leads the Israelites to the high theological declaration, "Who is like You, O LORD, among the gods? Who is like You, glorious in holiness, Fearful in praises, doing wonders" (Exod 15:11)? "You in Your mercy have led forth the people whom You have redeemed; You have guided them in Your strength To Your holy habitation" (Exod 15:13). From the moment that Israel received this community identity as "the people whom You have redeemed," their theological truths and the worship that derived from them were rooted in historical experience with a view to the future. All their theology, in fact, derives from the unfolding drama of God's redemptive presence, power and provisions.

The same is true of their ethical norms and legal principles. These grow directly out of their lived experience, not as some detached and independent rules, but rules that are dependent upon and reflective of that same redemptive drama. All of the Ten Commandments are founded on narrative; first, the exodus from Egypt, the affecting of God's covenantal promise, but also going back as far as the drama of creation. "I am the LORD your God, who brought you out of the land of Egypt, out of the house of bondage. You shall have no other gods before Me" (Exod 20:2-3). The "rule" is rooted in the redemptive covenantal relationship affected by God. The same idea is noticeable in the Sabbath law. 
Remember the Sabbath day, to keep it holy. Six days you shall labor and do all your work, but the seventh day is the Sabbath of the LORD your God. In it you shall do no work: . . . For in six days the LORD made the heavens and the earth, the sea, and all that is in them, and rested the seventh day. Therefore the LORD blessed the Sabbath day and hallowed it. (Exod 20:8-11)

These moral precepts for industry and rest are founded upon God's own actions in creation week.

The narrative of God's actions in behalf of Israel is also the setting for ethical reflection in the New Testament for the church. Paul exhorts the church to see Israel's history, with which they have certain solidarity, as relevant for its own moral life. Scriptural history was "written before ... for our learning" (Rom 15:4) and, "all these things happened to [the Old Testament saints] as examples, and they were written for our admonition, on whom the ends of the ages have come" (1 Cor 10:11). Most definitively, Paul claims "All Scripture is God-breathed and is profitable for doctrine, for reproof, for correction, for instruction in righteousness" (2 Tim 3:16). ${ }^{18}$ The New Testament thus makes frequent reference to the Old Testament stories "not simply to show the theological continuity between the testaments, but to draw out the ethical implications of the Old Testament for the New Testament Church" (Wenham 2000, 130). Wenham argues that "Paul's theology [and ethic] is set within the framework of this grand narrative which begins with the creation and ends with Christ's second advent and the resurrection of the dead" $(2000,130)$.

18 Quite notably, at the time Paul wrote this there was no "New Testament" in terms of a book to read and teach, so his reference to "Scripture" in a New Testament epistle ratifies the doctrinal and ethical significance of the Old Testament in the church's educational task. 
God's covenant people must remember their Story. They must keep it in mind as that which made them who they are; God's own people. Israel is called to remember their exodus from Egypt as that historical event through which they have been introduced to their covenant-making God, Yahweh, and by which they were formed into a covenant community. Their remembrance is crucial for perpetuating that community as they transmit the narrative to their children and children's children. ${ }^{19}$ The church likewise is called to remember the whole history of Israel, and the covenants, as the basis for its existence (Eph 2:12-13). From the standpoint of this side of the cross of Christ, however, the church sees the story as culminating in the gospel of Christ, through whom came the inauguration of the new covenant as the basis of their communal identity, worship and ethic. In both cases, remembrance is not a mere recollection of or assent to the truth of historical data, but means being continually cognizant of God's Story that is even now unfolding and the role that those He has called to be His people presently play in the on-going drama.

[Biblically] memory is not simply a mental process of recollection, not just a disinterested remembrance of objective historical data; memory is to own a particular history as one's own, to own a past and to own it as constitutive of identity and determinative for [moral] discernment. In the New Testament and in the church there is no identity apart from memory, and no community apart from common memory. (Verhey 2003, 23)

The ethical task for God's covenant people requires remembering who they are as His people. This entails grasping their communal identity; a community formed by this great narrative of God's creative, covenant and redemptive acts and transformed by the

19

This whole theme of remembrance of the saving acts of God in Israel's behalf continually serves as the basis for their communal identity, theology and ethic, and the narrative to be repeated to their progeny is throughout the Old Testament, but is especially evident in all its elements in Deuteronomy chapter four to which the reader is now referred. 
same as they reenact, communally and in the world, Gods own actions toward them. ${ }^{20}$ For God's people, collective experience gives them, and reinforces in them, a collective identity and they became a community due to their common history and shared experience. From this common identity they derive their collective worship and ethical duties toward God and neighbor (Childs 1992, Verhey 2002 and 2003).

When we come to the biblical text seeking ethical wisdom and guidance, we must first and foremost acknowledge that it presents a worldview and ethic not so much propositionally or systematically as a metanarrative with profound moral implications; it is the narrative that forms the community, but it is also the remembered, cherished and retold Story that transforms the community to become more increasingly what it should be; a community reflecting in its conduct the character of the very God who formed and continues to transform it.

\section{The Main Character and Face of Biblical Narrative Ethics}

From this emerges a very key element to understanding the biblical ethic. In this Story, ethical behavior is imitative. Wenham makes a case for "the imitation of God as [the] integrating ethical principle" $(2000,104)$. "The ethical expectations of the Old Testament are higher than the legal rules," he states, "many of the laws and ethical demands have a motive clause attached which justifies the course of behavior" $(2000,104)$. After noting the Decalogue's Sabbath law as rooted in the Creation Story, as we did above, Wenham continues, "The book of the covenant urges compassion for debtors, 'for I am

20

Below, I will discuss at length the significance of baptism and communion as dramas of remembrance and reenactment, and their bearing on Christian bioethics. 
compassionate' (Exod 22:27). Leviticus urges, 'Be holy, for I am holy' (Lev 11:45).

Deuteronomy forbids the taking of bribes, because God is "not partial and takes no bribe"" (Deut 10:17; 16:19) (Wenham 2000, 104). Wenham concludes, "The motivation to act in certain ways because that is how God acts is thus found in a wide variety of legal collections within the Pentateuch, and it therefore seems likely that it is assumed within the narratives as well" (Wenham 2000, 104-5).

Wenham also argues that the ultimate rationale for imitation of God is the biblical concept of the image of God, taking us back to both the Creation as well as Covenant motifs. "It is now accepted on the basis of extra- and intrabiblical parallels that mankind is viewed as God's representative on earth. He is God's vice-regent, appointed to rule the earth in a god-like way. He is given dominion over other creatures (Gen 1:28; Ps 8:4-8). Human actions are expected to echo divine" (Wenham 2000, 105). Here is where we must appreciate the functional and dynamic understanding of the image of God as standard. His image is a moral standard for which we must strive. It is not only a static possession which gives each human unconditional worth, but a dynamic process set before each of us as an ideal for which to strive. This ideal is revealed in the actions of God toward humans as the model for our ethical behavior. Verhey notes how ethical expectations grow out of a remembering of God's own actions.

To remember God's rescue from Pharaoh's oppression took shape in obedience to a commandment not to oppress a hired hand or to cheat him out of a living (Lev. 19:13). To remember God's gift of manna, enough for all to share, took shape in not piling up lands upon lands or riches upon riches and in leaving the edges of the field unharvested for the poor (Lev. 19:9-10). To remember the stories took shape in Jubilee dispositions to restore the slave to freedom, to share the land, to do justice, and to love kindness (Lev. 25) ... To remember the stories was to live them, not just to recall them. (2003, 24-5 emphasis mine) 
All in all, the biblical record "sets out a vision of human beings made in the image of God, his representatives on earth, and therefore obligated to imitate God in their dealings with one another and with other creatures" (Wenham 2000, 107).

Ethics as imitation carries directly into the New Testament as well, where imitation of God is tantamount to imitating Christ. The ultimate goal in salvation is that believers be "conformed to the image of His Son" (Rom 8:29). Jesus emphasizes this in His own teachings. He charges His followers to "love one another, even as I have loved you" (John 13:34). The Apostle Peter, echoing the Hebrew tradition in Leviticus, urges his readers, "As He who has called you is holy, you also be holy in all manner of conduct, because it is written, 'Be holy, for I am holy'" (1 Pet 1:15), demonstrating continuity in this principle of imitation between the Hebrew and Christian traditions. Peter embeds this call to holiness in the filial nature of the new covenant by calling them "children" who call on the "Father" (1:14, 17; cf. 2 Cor 6:16-18).

Holiness seems to be the essence, the very core, of moral character, expected of those who have owned this Story and entered covenant with God. Covenant was about relationship with the Holy God and to be this God's people meant to reflect His own character, not just slavishly keep His commands. Paul, drawing on his understanding of Christianity's indebtedness to the covenant and its attendant blessings (2 Cor 6:16-18), reminds Christians that living in light of these promises means to "cleanse ourselves from all filthiness of flesh and spirit, perfecting holiness in reverence toward God" (2 Cor 7:1). This draws attention to the inwardness of the moral life, not its outward conformity. Paul makes imitation of God in Christ the conspicuous hallmark of the ethical life when he tells the 
Ephesians, "Be imitators of God, as dear children, and walk in love, as Christ also has loved us" (Eph 5:1-2 emphasis mine).

So ethics, for those who profess to know God and His Christ, means imitating the divine actions God has done on our behalf. To imitate them, we must immerse ourselves in them. Childs' has effectively wedded the concepts of narrative (what God has done) and ethics (what we should be and do in light of this).

To know the love of God and trust in it, is to become a people of love. To know the mercy of God is to become a people who are merciful. To know the creator God who cares for the earth and everything that is in it is to become a people who are good stewards of that creation. To know God in Jesus Christ as the one who gave himself up for all people is to be a people ready to receive and affirm the worth of all people, even our enemies. To know God in Jesus as the creator and redeemer of all life is to be a people who uphold the value of life. In these and many other ways we ... become a people whose choices in life for the right and good are a reenactment of God's action in our life. (Childs 1992, 6)

This provides a rich and profound basis for developing a biblically informed approach to doing bioethics in the church. The biblical story is a story for remembrance and reenactment. In fact true remembrance, biblically speaking, cannot but reenact; not by some rote or ritual, but a genuine ownership of the Story that gives our lives shape, perspective, meaning and direction, both individually and communally. We are responsible for knowing His Story best of all; not only as a story to love, but a story to live.

Although Jesus is the summation and center-piece of the greater narrative, the ethically defining aspect of the Story is the Incarnation. The fulcrum on which the whole Story hinges is God's visit to earth in human form and flesh in the person of Jesus the Christ (Phil 2:6-7). This was, as we saw, the ultimate proof of His desire to dwell with His people whom He had created. The Word "became flesh" to "tabernacle among us" (John 1:14), to 
"declare" the Father to us (John 1:18), and to "show us the Father" (John 14:8-9) and thus what a life pleasing to Him looks like (John 8:29). Jesus served as the definitive moral model for our ethical lives. But this hardly involves a mere looking at Jesus' acts as portrayed in the Gospels and copying them, rather, "the imitation of Christ moves beyond mere deeds. It is neither possible nor desirable to try to determine how Jesus would act in every context. The life of imitation involves being motivated by the ideals, goals and purposes that moved Jesus" (Grenz 1997, 268).

This is precisely what Verhey means when he speaks of the church as a moral community "remembering Jesus" (Verhey 2002 and 2003). For him, the ethical and bioethical task of the church is to draw upon the biblical narrative, especially the life of Christ, as the primary "resource for nurturing, sustaining, renewing and reforming the church as a community of moral discourse and discernment" (Verhey 2002, 9-10). He calls this living a life "worthy of the gospel" (Phil 1:27). For Verhey, and others (Hauerwas 1989, Childs 1992, Wheeler 1996; Grenz 1997 and Eyer 1998, 2000), when faced with questions, especially bioethical questions involving human well-being and life and death, it is not enough, in fact it is not appropriate, to reduce such decisions to mere principles and pragmatics. We must, as God's covenant community, reflect on them and ask ourselves, what does faithfulness in the covenant relationship look like for us in this concrete situation as a community and as individuals? We must ask this together, as a community, for no one person has the definitive answer. This is the essence of the task of the church as a moral community. 
The Church as Moral Community

Having discussed the importance of community in a biblical narrative ethic, we now turn to what it actually means to identify the church as a moral community that engages the process of (bio)ethical discernment. We will consider the privilege, preservation, parameters and practice of the church as a moral community.

\section{The Privilege and Priority of Moral Community}

A strong case can be made that nearly every New Testament admonition is an admonition to the community not the individual. If seen in this light, the biblical directives take on a new significance. For example we are told, "(you; plural) stop being conformed to this world and (you; plural) be transformed by the renewing of your (plural, that is communal) mind, in order that you (plural; thus together) might prove that good and acceptable and perfect will of God" (Rom 12:2). Most of the imperatives in these letters of theological and moral instruction are written with the first person plural (let us) and second person plural (you all) casting the Christian life into the life of a community of believers living together and striving together to live out their faith. This is not to say that the life of the individual believer is not in consideration in these passages, it just reminds each and every individual believer that they are a member of a greater body of believers and not alone in the Christian life. ${ }^{21}$ When we consider the challenges that life intrinsically presents us as

${ }^{21}$ Budziszewski argues that one of the reasons young people leaving our churches and, entering college, lose their faith is that they have not been taught that Christianity is a community, not a solitary, experience. Accordingly, "what they really need is the correction of their excessively individualistic ecclesiology" $(2003,108)$. The 
humans and Christians, we should welcome the idea of community as one of the blessings of what it means to be saved because, as Childs shares,

We really do need each other. The lonely pursuit of the moral life is an exercise in despair; none of us has what it takes to understand all that needs understanding and do all that needs doing. It is part of the good news of our salvation in Jesus Christ that our salvation is not an individual happening but that the grace of God has created us anew in community, intimately linked to each other as the body of Christ. (Childs 1992, 9)

Childs finds this biblical imagery to be part of the good news that we are saved as a community, not merely as individuals. "It invites us to value the gifts that all of us bring to our common tasks. Your gifts are mine, and my gifts are yours” (Childs 1992, 7). In a complex world that presents increasingly difficult moral problems, especially concerns regarding the dignity of human life, and dilemmas at the beginning, in the midst of and at the end of life, the last thing we should do is leave each other to ourselves to hash out an appropriate biblical response. We must realize that God has given us each other, and gifted us through His Holy Spirit to guide, admonish, instruct and teach one another. "Our pursuit of the Christian ethic is ... like playing in an orchestra in which each of us has his or her own particular part to play in harmonious concert with others and each one of us shares in the ownership of the total sound that is produced" (Childs 1992, 9).

Verhey highlights Paul's compliment to the believers at Rome that they are "full of goodness and filled with all knowledge, and able to instruct one another" (Rom 15:4) (2002 and 2003). Paul is more explicit to the believers at Colossae where he commands them to "let the word of Christ dwell in you (plural) richly, teaching and admonishing one

community narrative ethic, as discussed herein, will definitely serve this purpose if his assessment is accurate. 
another in all wisdom" (Col 3:16). There was definitely a place for skilled and gifted leadership in the church, but Paul even reminds them that they were given to the church "for the equipping of the saints for the work of ministry" (Eph 4:11-12). In our contemporary biotech culture bioethical instruction, admonition and teaching addressing our conceptions, pregnancies, births, health and sicknesses, diseases, disabilities, aging, dying and death is a relevant application of these passages. Consequently we should be seeking to cultivate within our churches an environment conducive to, and that encourages "talking together and thinking together and praying together about the ways in which the Christian story can form and inform ... guide and limit the uses of new medical powers" (Verhey 2002, 89).

\section{Preserving Moral Community}

Moral community, or community per se, is under attack from many fronts. Below are two important ones that call for vigilance on the part of any local church. Churches that see community as a privilege and priority will guard against them as they strive to live out a life consistent with the Story in which the concept of community is, as we have seen, indispensable.

\section{Guarding Against Autonomy}

Autonomy, a primary, if not centrally governing, principle of secular bioethics, threatens community. While a case can and should be made that there is a place for the legal "right to privacy" in the Christian's life, as in all others, to live without governmental intrusion, and thus express their faith and values as autonomous individuals, it is important to see that autonomy has little to no place in the community life of the church. 
Rae, in fact, speaks of the "corrosive effects of autonomy and individualism" (Rae 1999) in our churches today and Verhey claims that ownership of the Story does not "allow autonomy to monopolize our moral attention" (Verhey 2003, 168).

Autonomy takes a lesser prominence in a Christian ethic in two ways. First is the matter of divine authority. "In one sense, to speak of autonomy for the Christian is somewhat of an oxymoron, since the Christian lives all of life under God's sovereign direction. The Christian is constrained by the moral parameters of God's word" (Rae 1999), an echo of Paul's sentiment that we "are not [our] own" (1 Cor 6:19). Second is the matter of community. The New Testament is filled with admonitions to temper our freedoms and individuality with love and responsibility to others in the community. Not just divine authority and ownership curbs our autonomy (1 Cor 6:19), but also, just as importantly, our being subject to one another in community.

In fact, one of the signs of a Spirit-filled believer, and by implication body, is a voluntary submission to "one another in the fear of God" (Eph 5:21). This qualification brings our submission in community under the ultimate authority of God.

One of the most distinctive aspects of moral thinking in the New Testament is its focus on the community of believers. The community of faith provides both the context and the rationale for moral reflection and judgment. This means that Christians turn to one another for counsel and insight, and are accountable to one another for the coherence of their conduct and their profession. But it also means that one of the primary ways in which behavior is judged is by its contribution to the wellbeing and growth of the community. (Wheeler 1996, 27-28)

Verhey applies the contrast of autonomous and community thinking to a pregnant unmarried woman who may be swayed by secular bioethics, which emphasizes her individual autonomy 
and freedom to choose the outcome of her pregnancy. On the other hand, the biblical Story would orient her and us away from autonomy and toward community.

The moral life is also about responding to and accepting (or not) things not of our choosing, about the experience of obligation within the relationships in which one simply finds oneself. The moral life is not just a matter of contracts between autonomous individuals; it is also a matter of honoring moral obligations that arise simply because we are all embedded in relationships, some of which are not our own choosing. (Verhey 2003, 211)

Community under divine authority, not autonomy, is what a bioethics faithful to the biblical Story will stress, and those who own that Story will submit themselves and their bioethical decisions, to this community.

\section{Guarding Against Technology}

Another threat to community is technology. This is not to degrade technology per se. Technology is definitely part of the fulfillment of our creation mandate to have dominion, as we have taken great pains above to explain. Further, we are not merely speaking of biotechnology, but rather all the ways we seek to control our natural environment to simplify and enhance our lives. This, also, is inherent to our being created in God's image with "dominion" over the rest of creation. Yet for all the promise and pleasure that technology offers, there are pitfalls and perils with this two-edged sword of which God's people need to be aware and prophetically declare its caveats in light of our corruption.

According to Basil Mitchell, where modern technology thrives it releases us from "natural constraints" frees us to emphasize "self fulfillment and self-expression" as individuals (Mitchell 1990, 612-13). It feeds our individualism and autonomy, frees us from one another, and "the resulting fragmentation leads to a loss of community; and communities 
cannot be rebuilt through merely contractual relationships between atomized individuals. There is a felt need for shared values and common institutions" (Mitchell 1990, 613). We might also say common stories or narratives.

Communities are often formed by a shared history; something that draws individuals to each other because they share a common narrative. We must ever be cautious that technology enables and encourages more atomization and individualism. Technology can easily pull people away from each other and thus away from a sense of belonging to each other in community. We close ourselves off from each other with our iPods, MP3 players and Xboxes. Televised services and live or streaming video via the internet can make Christians feel they do not need to gather with the body of Christ. But community is integral, as we have seen, to the biblical Story, and ethics is intended to be, in large part, a communal process for helping each other discover how this Story or worldview, bears upon our moral lives. Mitchell further states, "Serious attempts to grapple with the moral challenges of the contemporary world find people exploring the implications for ethics of what is known about human nature, and man's place in the natural order, in a manner that makes Christian teaching about these matters once more clearly relevant" (Mitchell 1990, 612). This, of course, returns us to the importance of the biblical metanarrative as the context for understanding and addressing contemporary bioethics. An ownership of the biblical metanarrative will bring our technology into captivity to serve the Story, not allow it to captivate us and draw us away from living the Story together. 
Parameters of Moral Community

Verhey's purpose in writing is to "nurture and sustain the congregational practice of moral discourse and deliberation and discernment-specifically about bioethics-by attending to and engaging in the practice of reading Scripture," and by this he emphasizes the "whole story" of Scripture, from creation to consummation, culminating in the Gospel of Christ, as outlined above (Verhey 2002 and 2003). He wants to "call Christian communities to test decisions and judgments about bioethics by the churches' common memory and shared hope [the Story], not by some generic moral standard." "I hope for the renewal of congregational life" he states, "and specifically for the renewal of communities of faith as communities of moral discourse, character formation, and moral action in bioethics" (Verhey 2003, 31).

Childs speaks of nurturing the ethical life in a "community of promise" by which he envisions the people of God gathered around the word of God dialoguing over issues in the context of their common "faith;" story about and trust in God, "formation;" how that story shapes their ethical lives, and "decision;" what shape their choices take in view of their faith and formation (Childs 1992). In this context, we have a shared communal identity and shared morality that informs our decisions. We are thus helping each other work out the implications of our faith as it bears on our bioethical challenges. By synthesizing the main proponents of Verhey (2002 and 2003) and Childs (1992), especially, I propose to discuss and apply four characteristics of the church as a moral community. 
A Community of Moral Discourse.

According to Verhey, churches are already communities of moral discourse to some extent in that they already talk about, even if informally, what they should and should not do when it comes to bioethical choices (Verhey 2002 and 2003). They even do this, somewhat, in an "effort to attend to God and to respond appropriately to God" (Verhey 2003, 29). This may not be structured or guided, but it happens more frequently than we may realize when God's people get together to talk and pray.

Often bioethical issues, unbeknownst to us, constitute the bulk of the requests on our prayer lists. We talk and pray about issues having to do with conception, pregnancy, birth, living, disease, disability, dying and death more than we may realize it, but we do this because we have at least a vague idea that somehow we share a common understanding of reality. We are not a community that may talk about moral issues, but do already, and it is precisely this fact that gives us our identity as a moral community. Discourse naturally and inevitably gives rise to the next level of moral deliberation.

\section{A Community of Moral Deliberation.}

Verhey observes "because moral discourse inevitably involves the giving and hearing of reasons, churches are also called to be communities of moral deliberation" (Verhey 2003, 29). For Verhey, this level of moral community involves the "giving and hearing of reasons" for the choices discussed during moral discourse; in other words a community of moral deliberation talks together "not only about what they ought to do, but also about why they ought to do it." They ask "why they ought to do one thing rather than another or something rather than nothing" (Verhey 2003, 30 emphasis his). 
At this level, members of congregations begin to be more accountable to each other and demonstrate that they realize, to some extent, that moral choices are not simply “'private matters' and no one else's business ... settled by the tastes and preferences of the free [autonomous] person" completely independent of the "community's discourse and mutual instruction" (Verhey 2002, 17). Personal decisions remain personal, and individual responsibility is not surrendered to the group completely, but personal choices are made and individual responsibility is exercised within the community, not secretly or privately. ${ }^{22}$ As stated in the above discussion on autonomy, ultimately, we submit our ethical lives to the moral authority of God's word, and the scrutiny of the moral community, the church.

But at this level, also, Verhey stresses the importance of recognizing that "there [is] no wooden scheme for deliberation, no simple checklist . . or set of first principles to be applied" (Verhey 2002, 19). In fact, during deliberation a community can draw from "a variety of sources" and we are not to "silence other voices and other sources" at this point (Verhey 2003, 64). Everyone involved should be allowed and encouraged to freely give their reasons for and against a particular choice in an effort to help each other make up our minds. This is definitely part of the edificatory duty of the church. To assist each other in moral improvement we must encourage people to think critically, and weigh all the reasons given for a particular course of moral action.

${ }^{22}$ Verhey exemplifies how first century churches seemed to realize this by showing how Philemon, while a private letter written to influence the personal response of one man, did not ignore that "the personal choice concerning Onesimus was open to the review of the whole church" (Verhey 2002, 17). 
There is a place for this kind of work even in Christian bioethics, because we can find ethical wisdom in other sources outside Scripture. If we hold to the Story, in fact, we know that God has created every human in His image, and embedded His moral law within them (Rom 2:14-15). Consequently, we can find useful ethical guidance from sources and traditions outside our Story, as such. We can find use in thinking about philosophical ethical principles like autonomy, non-malfeasance, beneficence, and justice, as does Wheeler (1996). ${ }^{23}$ If we prejudice ourselves against these other sources and voices due merely to their origin, we may miss out on important moral insights for solving our present challenges. Paul, for example, could quote pagan philosophers insofar as their statements were consistent with the Story God is telling (Acts 17:28; Titus 1:12-13). This leads into the third level of activity of the church as moral community which is discernment.

\section{A Community of Moral Discernment.}

This is the heart of the communal bioethical process. While there is value in considering reasons and principles from other sources, eventually there does come a time to filter the bioethical discussion in the church, and this means focusing on its primary rule for all faith and conduct, Scripture, and especially the definitive Story centered in Jesus. Paul tells us that faithfulness to this story means that all other principles and reasons must be

\section{3}

Wheeler (1996) discusses these and other medical ethical principles, such as informed consent, competence, voluntariness, futility, etc. but always, and usefully, casts them in light of the basic convictions of the theological story. This serves as an excellent example of how ministers, her primary audience, as well as Christians, can do the work of Christian moral discernment using the language of secular ethics. Verhey also gives an example of this when he discusses how Christian medicine took the language of the Hippocratic Oath and adapted it to the Story (2003, 6-8). 
brought into "captivity to the obedience of Christ" (2 Cor 10:5), and not allowed to "cheat [us] through philosophy and empty deceit according to the basic principles of the world, and not according to Christ" (Col 2:8).

While moral deliberation entails the "giving and hearing of reasons" Verhey notes, "not all reasons . . . may have the same weight within Christian churches. The reasons have to be tested" (Verhey 2003, 29). Verhey explains what this testing involves. "Reasons were given and heard in the community, but even the reasons had finally to be tested in the community-and defended or discarded or qualified-by their coherence with the gospel" (Verhey 2000 and 2003). Stassen and Gushee provide a similar account of discernment in Christian community.

What needs to happen is a thoughtful encounter between Christ-followers, bound together in community, already practiced in a discerning way of life dedicated to seeking the kingdom [the "theological basic-convictions" or biblical narrative], with the new issues demanding Christian response. Certain options, certain trajectories under consideration, will be rejected (or embraced) by such a community according to whether or not they "fit" with the moral vision and moral character of this particular people. (2003, 254 emphasis mine)

"Discourse and discernment [take] place in this community in the service of the people's communal attempt to discern the shape and style of a life "worthy of the gospel of Christ'" (Verhey 2002, 19). Verhey provides a substantive explanation of discernment.

Discernment is . . the ability to recognize "fittingness." In reading Scripture, discernment is the ability to recognize the plot of the story, to see the wholeness of Scripture, and to order the interpretation of any part of it toward that whole. It is to recognize how a statute, a proverb, or a story "fits" the whole story. And in reading Scripture as "useful . . . for training in righteousness" (2 Tim. 3:16), discernment is the ability to plot our own lives in ways that "fit"" the whole of Scripture, the skill to order our lives toward that whole. (Verhey 2003, 59) 
Essentially, discernment is "the virtue" of questioning whether our views and positions “cohere with the story" (Verhey 2003, 309).

This comprehensive explanation involves two key activities in the process of discernment; (1) plotting the Story as a whole and (2) plotting our stories in ways that fit the whole Story. Plotting the Story as a whole means, largely, what we have done already in outlining the motifs of Scripture from Creation to Consummation centered in Christ.

Verhey "plots" this Story, for example, in his discussion of physician assisted suicide (Verhey 2003, 309-311). From the perspective of Creation, Corruption, Covenant and Consummation (although he does not use these terms, he uses these themes), explains why Judas' suicide does not "fit" the Story. That is, he takes a story in Scripture (the singular story of Judas) and tries to see it in relation to "the wholeness of Scripture," (from Creation to Consummation) which is the first task of Christian discernment. He concludes that Judas' suicide does not only fail to fit with this Story, neither does it cohere with the "gospel of Christ," who embraced suffering and lament and community in the face of death, which is the ultimate standard or "test" for Christian moral discernment.

He then proceeds to discuss our stories and struggles with dying and death, and how enlisting our physicians as our mercy killers does not fit with the Story either. "Christians will not choose death, will not intend death," he writes, but at the same time they will not, in view of "eschatological realism" (meaning a correct understanding of the coming consummation), seek "medical technology to rescue the human condition from mortality or the vulnerability of suffering" (Verhey 2003, 323). "Apart from this eschatological realism our culture is at risk of extravagant (and idolatrous) expectations of medicine, tempted to 
regard the physician as a medical wizard whose magic will deliver us from death and suffering" (2003, 323-4). Verhey finally discusses how the Story might help us plot our stories of dying and death in our communities, and this includes seeing that

The story of Jesus [crucified yet risen] is a glad story indeed, it does not deny the sad truth about our world. It does not announce here and now an end to our pains or avoidance of our death, but it does provide an unshakable assurance that we do not suffer alone, that we are not and will not be abandoned, that Jesus suffers with us, that God cares. The glad story of Jesus is indeed a hard reminder that in a world like this one, however righteous or repentant we are, we cannot expect to be spared pain, sorrow or death. (Verhey 2003, 324)

In all of our bioethics, as Verhey illustrates with the issue of assisted suicide, discernment eventuates in the realigning of our lives with the plot of the Story. Verhey remarks, "we must set all the stories of our lives alongside the Story of Scripture, that they may be made new" (Verhey 2003, 67). ${ }^{24}$

We must also realize that this kind of discernment is hard work.

Discernment is a complex and practical wisdom. It does not rely on the simple application of general principles (whether of hermeneutics or of ethics) to particular cases . . . [I]n Scripture . . there is no theory of discernment . . . no checklist, no flowchart for decisions, no tidy instructions how to read and perform Scripture in “"fitting” ways. (Verhey 2003, 61)

\section{4}

This is precisely what Verhey seeks to do as a model for moral discernment in Christian community. Physician assisted suicide is just one bioethical issue with which he demonstrates the process of discernment according to "the gospel of Christ." He also discusses in detail what discernment might look like with issues dealing with human sexuality and marriage, economics, social justice, human suffering and caring for the suffering, the Human Genome, abortion, assisted reproduction, neonates and infanticide and the allocation of rare medical resources. This enumeration summarizes the main topics he discusses in Remembering Jesus (2000) and Reading the Bible in the Strange World of Medicine (2003). 
Nevertheless, we are still called as a community to discernment insofar as we are called to "follow the one of whom the story is told, ready to order one's life and the common life to fit the story" (Verhey 2003, 59), and to live our individual and common lives "worthy of the gospel of Christ."

The "gospel of Christ" is the standard by which we should judge our character, conduct and choices as Christians. This is where we demonstrate true discipleship; a readiness to be disciplined by the Story (Verhey 2003). Discernment, discipline and discipleship are the essence of what it means to remember Jesus and live in a manner "worthy of the gospel."

Discernment in Christian community depends, finally, on remembering the story of Jesus. And Scripture is useful for that remembering. It is by reading Scripture that the church remembers! Remembering is the good that the Christian community aims at in its practice of reading Scripture. The greatest danger of the Christian life is still forgetfulness, and reading Scripture is still the remedy. (Verhey 2003, 67)

The church remembers Jesus by reading the gospels which “... give literary expression to the oral tradition in which the church's memory of the words and deeds of Jesus was handed down" (Verhey 2002). 'Each gospel is a 'remembrance,' a literary commemoration of the crucified and risen Lord, forming character and shaping conduct into something worthy of the gospel." There is no living "worthy of the gospel" without the gospels. We must approach our reading of Scripture, and the gospels, with a view to remembering, which is "not just a mental process of recollection, not just as [sic] disinterested recall of historical facts," rather it is learning "to own a past as [our] past in the continuing church, and to own it as constitutive of identity and determinative for discernment" (Verhey 2003, 55 emphasis mine). 
This whole process of moral discernment, in fact of being a moral community, "invites people to bring their conduct and character into coherence with the story they own as their own in Christian community" (Verhey 2003, 29). The community is definitely the context for discernment in Verhey's model. "Communal discernment, or the perception of what is fitting, in the church was always to be the discernment of what is fitting to, or worthy of the gospel. It was the gospel that made them a community, and it was the gospel, 'the mercies of God,' which called them to discernment not to be conformed to this age, but transformed by the renewing of their [communal] mind (Rom 12:1-2)" (Verhey 2003, 20). Verhey's account of remembering Jesus and the Gospel, then, is what is involved in the renewal of the Christian mind and worldview living, the central task to Christian bioethical education in the local church.

This places bioethics, the whole ethical endeavor, within the community of the local church and outside of the philosophical realm of seeking abstract moral principles. It also provides a deeply personal and accessible context for the Christian community's ethical thinking and choosing; no matter what a person's educational or academic background. This whole effort gives us a communal identity, and sense of community. Verhey concludes, "Contemporary churches, then, continue to be-and to be called to becommunities of discourse and deliberation and discernment by remembering Jesus and by transforming questions of character and conduct into the question of how they may live the story they still love to tell" (Verhey 2003, 39). 
A Community of Moral Decision.

The bottom line is that when we are faced with ethical decisions we want to know what we ought to do, and what we ought to leave undone. And this is especially true in matters of bioethics. "Bioethics deals with the ethics of making choices available to us as a result of breakthroughs in medical technology" (Eyer 2000, 7 emphasis mine).

Eyer (2000) and Childs (1992) address the important aspect of decision making when we may remain, even after careful deliberation and discernment, with more confusion than confidence as we try to sort through a moral dilemma. We must admit, as does Eyer, that "neither sincerity nor good intentions nor following ethical guidelines to the letter of the law will guarantee that our ethical decisions are pleasing to God. We can never be certain whether our thoughts, words or decisions are more influenced by the sinner in us than the saint" (Eyer 2000, 75). Eyer's realism can be disarming, but it's worth is in its sobering awareness that, "in a fallen world a Christian [cannot] make decisions without being influenced by the Old Adam [corruption] still within him" (Eyer 2000, 75). He makes much of the reality of our sinful and fallen condition and its pervasiveness even when we are trying to do good, but this is precisely what one who understands the Story, particularly the story of our Corruption, should expect.

This seems to be consistent with Paul's own view that "when I would do good, evil is present with me" (Rom 7:21). For those who know the Story, we recognize our situation as God's created beings simultaneously caught in the tension between the bondage of corruption and the blessing of covenant which anticipates the final consummation. We may be "skilled in the word of righteousness" and thus "by reason of use [of that word] have 
[our] senses exercised to discern both good and evil" (Heb 5:13-14), but even with this kind of maturity we must admit that the tension and moral confusion we face is part of the givenness of our corrupt state due to the presence of evil in God's good creation. This leads to ambiguity and ambivalence at times in our moral decision making, and we should expect it. Humble awareness of this condition should lead us to agree with Childs that, "Any method of ethical decision making that simplistically assumes that we can justify ourselves by using that method to demonstrate how we have done the right thing beyond a shadow of a doubt would not be true to the reality of life as we experience it" $(1992,76)$.

Although the sobering reality is, as Eyer reminds us, that "no Christian will make the right decisions all of the time" (Eyer 2000, 93), this should neither lead us to despair, nor to a disregard of the process of moral discernment. What it should do is lead us away from the delusion that we can be right beyond a shadow of a doubt, and thus produce humility and pause in the ethical and bioethical task. "All a Christian can do is to examine critically the dilemma, evaluate it in light of the Bible [the Story], and in good conscience make the choice believed to be consistent with the will of God" (Eyer 2000, 75). Our confusion and our ambivalence over right and wrong, while it should give us humble pause, should not render the Christian "paralyzed by indecision" (Eyer 2000, 75).

Childs refers to the importance of "building into our understanding how the word of God [the Story] . . . illumines the human situation of life in a fallen and imperfect world and provides us with the courage to act even in the face of . . . hard and even tragic choices" (Childs 1992, 76). He also comments on this dire situation we face in light of the Story. "Even when our motives and intentions appear to be at their noblest and we have done 
our best to make a good decision, ethical dilemmas are often so intransigent as to leave us with no sense of moral certitude ... and we are forced to recognize and live with the radical ambiguity of some of our decisions and the tragic character of a world whose full redemption is not yet consummated" (Childs 1992, 77).

A critical and final element to our discussion of decision is that we cultivate an awareness that we are living under the gospel of Christ and the "forgiveness of sins." As noted in chapter one, Christians often do not bring their present bioethical challenges or struggles, or their past choices, to the church for fear of being judged, or even shunned due to having made what others consider a "wrong" decision. Our Story tells us that the covenanting God, in Christ, has paid for our sins, and is in the business of redeeming us, and bringing beauty out of the brokenness of our lives. We are all moral failures, and will continue to be, and bioethical education in a local church, even when done properly, will surface a sense of moral failure on the part of some as they realize how they have failed to fulfill His will in areas like abortion, reproductive technologies, end of life decisions, etc. So along with its strong message of human dignity deriving from the story of Creation, the church must be prepared to communicate its story of Covenant and redemption to the real pain that will surface along with it; bringing, as the redeeming God of covenant does, beauty out of brokenness.

Before proceeding to the practicalities of applying this model to ethical issues, I will give a brief definition of these interconnected and overlapping phases of the church as moral community. (1) Moral Discourse; The activity of discussing and praying about what should be done and left undone especially with regard to matters involving conception, 
pregnancy, birth, life, health, sickness, disease, disability, dying and death. (2) Moral Deliberation; The process of giving and hearing reasons for the choices we have made or intend to make with regard to these areas. (3) Moral Discernment; Seeking to align or fit what we do and what we leave undone in these matters to the Story of Scripture, especially the Gospel of Jesus Christ as the culmination of that Story. (4) Moral Decision; The actual making of a choice regarding these matters based upon the insights gained through the process of discourse, deliberation and discernment with the ultimate view of honoring God and witnessing to His moral will in the community of faith and the world around us.

\section{The Practice of Moral Community}

Now that we have considered the concept of the church as a moral community, we now turn to seeing how that plays out in a practical sense. I will first discuss general considerations that can apply to any Christian bioethics in a local church, and then analyze what that might look like for one particular local congregation.

\section{General Considerations}

In order for churches to thrive as moral communities of discourse, deliberation, discernment and decision in this age of biotech, and be faithful to their bioethical task, church leaders must first be committed to the task themselves and thus strive to create an environment where this process can take place. Part of this entails a regular rehearsal of the Story so that God's people receive regular reminders of the narrative that formed, and transforms, their community. Prerequisite to this, of course, is an awareness of and immersion in the biblical narrative, as the Story it is, themselves. Church leaders must 
help their congregants recognize their place in this unfolding Story as God's people and then see themselves as God's local congregation in the city in which they reside for worship of and witness to the true and living God and the Gospel of Jesus Christ. To this end, I would recommend the following reading list to pastors in the following order.

1. Holy People Holy Lives: Law and Gospel in Bioethics by Richard C. Eyer. 2000, Concordia Publishing House

2. "Bioethics: Obstacle or Opportunity for the Gospel?" Lausanne Occasional Paper (LOP) No. 58, by the Lausanne Committee for World Evangelization, 2005. (available through their website - http://www.lausanne.org )

3. Stewards of Life: Bioethics and Pastoral Care by Sondra Ely Wheeler. 1996. Abingdon Press

4. Faith, Formation and Decision by James M. Childs Jr. 1992, Fortress Press

5. Remembering Jesus: Christian Community, Scripture and the Moral Life by Allen Verhey. 2002, Eerdmans

6. Reading the Bible in the Strange World of Medicine by Allen Verhey. 2003, Eerdmans

During and following a reading of these materials, pastors can begin to incorporate these insights into their preaching and teaching and to begin cultivating an environment where God's people think of their personal stories, including their bioethical stories, more in terms of unfolding within the context of God's bigger Story. In addition to reading these materials, church leaders need to provide educational opportunities, through Sunday school classes and 
electives that actually give God's people the concrete opportunity to conscientiously be and act as a community of moral discourse, deliberation, discernment and decision.

The nature of this instruction within the church would, of course, begin with helping people appreciate the need for bioethical dialogue in view of current trends in biotechnology, a definition of bioethics and identification of bioethical issues that the group finds relevant. To stimulate this dialogue, members should be invited to share their stories of conception, pregnancy, birth, health and illness, disease, disability, dying and death. Once these issues are on the table, the context for discussing them, the Christian mind and worldview, would need to be articulated, with a special emphasis on the biblical Story that encompasses and explains all other stories, centered on and culminating in the Gospel of Christ.

Then members should be taught and guided through the process of discourse, deliberation, discernment and decision. Pastors can do this themselves or, better, equip interested believers for the task. Referring to these issues and themes from the pulpit should stimulate interest in some individuals for further training and preparation.

In the actual process one resource that proves useful as a tool for this is the Lausanne Occasional Paper, the second half of which provides ready-made discussions on real life bioethical situations. It outlines eight areas of bioethical concern; justice in health care, care-giver patient relationships, end-of-life care, abortion, reproductive technologies, stem cell research, genetic modification in agriculture and human enhancement. Each issue is introduced with a real life story showing the plausibility of these issues for our everyday lives, after which three basic questions are applied to them; (1) What issues does this story 
raise? (2) What does the Bible say (which deals with the process of moral discernment; fitting the story into the Story) and (3) What opportunities for the gospel are there? (this question being in keeping with the title of the paper, and demonstrating the relevance of bioethical inquiry in the church as a platform for sharing the good news).

Seeing that each denomination will have its own unique doctrinal statements, I want to encourage a congregation to start with theirs as a basis for plotting the story of Scripture. It would seem that doctrinal statements, no matter what particular Christian denomination they will come from, will always include more than theological propositions separated from the basic outline of the biblical narrative. But what we need to do, like the Bible, is capitalize upon the narrative aspects of our doctrinal statements as the basis for bioethical reflection. Every doctrinal statement that strives to be true to the Bible will necessarily have some casting of otherwise ontological theological propositions into concrete story form and historical narrative as we shall see directly.

Local Applications

I will illustrate this process with the faith tradition, philosophy and ministry goals of Heritage Baptist Church (HBC) in Lynchburg, VA. What follows is an analysis of HBC's official doctrinal statement and philosophy of ministry to show how it naturally, though perhaps unintentionally, presents the Story of Scripture, and thus a firm foundation for the process of moral discernment outlined above.

Stassen and Gushee state that ethical rules and principles need to be Clearly embodied in narratives, church practices and faith-community understandings. Rules and principles are not suspended in mid-air; they get their meaning and have their context in the realistic, embodied, Hebraic narrative of both 
Testaments, and in their analogous function in a realistic, embodied way of living in our social context. (Stassen and Gushee 2003, 117)

This statement points up three important contexts for bioethical education in the local church. They are a given church's "embodied narratives, church practices and faith-community understandings." While practices and faith community understandings will be at least slightly different for each local congregation, at the same time they will be based on the timeless "embodied . . . narrative of both Testaments," both of which need to be applied to an "embodied way of living in our social context." Likewise, Verhey urges that those who are going to talk of "God in bioethics should not neglect congregational life," and in this context he means that individual churches engage in "faithful and creative attention to their own traditions" in order to "renew" their "communities and moral discourse" (Verhey 2003, 30). In the spirit of Stassen, Gushee and Verhey's recommendations I want to use HBC's membership manual New Connections; Our Gateway to Membership (hence NC) which is designed to give prospective members "an overview of the beliefs, purpose, philosophy, strategy and ministries of Heritage Baptist Church" (NC, iii). Taught by the Senior Pastor, Dr. Jerry Kroll, as well as other pastors and deacons on staff, New Connections is designed to teach students of the 14 week elective to know what HBC believes and how it functions as a body. The hope is to train soldiers, not just obtain new members, by helping them discover their giftedness, ministry interests and strengths and the ministry opportunity in which they can use these to help HBC reach its goals.

HBC was founded on April 24, 1977 and has grown to an attendance of approximately 1500 by the end of 2006 (NC, 5). It is "an independent Baptist church . . organized around local leadership" (NC, 5). It's motto is “A Place to Belong; A Place to 
Become," since from the beginning of time "man has an innate desire to belong to God" who created man with both spiritual and social needs (NC, 8). In view of this, HBC "aggressively presents the Gospel (death, burial and resurrection of Jesus Christ) so that lost sinners might believe and belong to Christ. Heritage also provides a loving, caring fellowship to give believers a place to belong to the community of saints" (NC, 8).

Already, even before its official statements of doctrine begin, the emphasis at HBC, as evident in its very motto, is to find a place of community. As we have seen, community is central to doing bioethics in the local church, so this focus is, right from the start, conducive to telling the Story in community as that which forms and even transforms it and gives it identity.

Covenant. The manual then introduces the Church Constitution. Article I is the name, Article II are the Articles of Faith which are discussed in detail later (NC, 25). Article III is the church covenant and begins with a declaration of receiving the gospel, being baptized in the name of the Father, and of the Son and of the Holy Spirit, and entering "into covenant with one another as one body in Christ." Even here the importance of the Gospel for the church is highlighted, which can lead into discussing living our lives in a way that is "worthy of the gospel" as the whole foundation for bioethical dialogue as we have seen. The Gospel is what formed HBC and those who join this covenant community must be believers in the gospel who have experienced baptism.

On this basis members pledge to "engage" to do several things as faithful members of this covenant to include: walking together in Christian love, and advance the spiritual growth of the church, to relieve the poor and spread the gospel to the nations, to 
maintain strong families and religiously educate our children, to be exemplary in our deportment, watch over one another in brotherly love, remember one another in prayer, and aid one another in sickness and distress.

All of these avowed "engagements" have bioethical significance. Bioethics, as we have said, are a large part of the defining issues of our day, but they involve perspectives on our conceptions, pregnancies, births, health and sicknesses, diseases, disabilities, aging and deaths; the stuff life is made of. The church must show how its message bears on all of these areas of life and HBCs covenant to relieve the poor, educate children, be exemplary in behavior, watch over and pray for each other, and aid one another in sickness and distress, are inherent to the bioethical task. HBC has already covenanted together, although perhaps unknowingly, around cultivating an environment conducive to a robust bioethics.

Salvation and the Gospel. When in the manual HBC begins to articulate its beliefs, it begins with the presentation of the plan of "Salvation and the Gospel" (NC, 15). In standard form and verses common to the "plan of salvation" HBC seeks to explain what they believe about the "good news, the gospel, of God's salvation" (NC, 15 emphasis theirs). In broad strokes, the manual speaks of God's Creation, Man's Rebellion, God's Provision, and Man's Decision. Apart from the cosmic aspect of the Consummation, this plan of salvation touches on each of the five motifs of the biblical narrative, and although it is not being presented as a Story, per se, it uses verses to illustrate the points that have a narrative essence to them. So it would be easy to introduce God's Big Story as the context for our moral discernment just on the basis of HBC's Gospel presentation. 
Ordinances. Next HBC discusses in detail its position on the ordinances of the church. There are only two; Baptism and the Lord's Supper. Although HBC does not call them "sacraments" due to "some churches [making] them a necessity for salvation [or "means of earning heaven"] rather than a symbol of God's grace" (NC, 17), they still discuss the original significance of "sacrament" as they relate to these ordinances.

Originally the word sacrament conveyed the true meaning of the ordinances. The Latin term, sacramentum, was originally used for the oath of loyalty taken by a Roman soldier. It consisted of two aspects: First there was the initial pledge. Whenever the soldier joined the Roman Army, he gave an initial pledge of his loyalty to Caesar, even if it meant his death. This pledge occurred only once at the time of his induction into the Roman army. Second, there was an annual recommitment of his loyalty to Rome. The annual pledge to death was given to his commanding officer. (NC, 17)

HBC then draws the analogy that "these two commitments correspond exactly to the two sacraments Jesus gave His church. Baptism is the initial commitment a believer makes after he has trusted Christ as his Savior. The Lord's Supper is the recurring commitment a believer makes as part of his regular worship in the body of Christ" (NC, 17)

Robert Song, writing specifically on the subject of bioethics and the church, observes how Christian bioethicists have recently, due to a "discontent" and "growing unease" with "secularism" and a purely "philosophical bioethics," have shifted toward a more "ecclesial ethics" in which "the distinctiveness of Christian ethics is given shape by the narrative of the community committed to the proclamation of Christ, and by grounding this narrative in the distinctive practices of that community, most notably the sacraments of baptism and eucharist" $(2005,334)$.

There is great significance for our bioethics (our stories of conception, pregnancy, birth, suffering, aging, dying and death) in these acts of worship. In fact, nothing 
better retells and identifies the Story which we as Christ's followers are living than these interactive dramas and remembrances of Jesus. Both of them retell the Story, culminating in the Gospel of Christ in which we "own" Christ's death, burial resurrection and return. Participation in both acts of worship is a public, or communal, declaration of our acceptance of this Story and implies a prior understanding and ownership of our being created, and utterly contingent, beings who have become corrupted and thus in desperate need of God's covenant to redeem us, and both anticipate the joy of consummation when the curse will finally be reversed and creation restored. As such, each of these dramas are themselves stories in miniature, depicting the Story that is the basis of our bioethical discernment.

There are no other activities in the church with such profound communal significance as Baptism and the Lord's Supper. Our Lord gave them to us, His covenant people, to perform regularly in the community of saints. They are forever important and expected as acts of individual and communal dedication and rededication to the Story. They are worshipful reminders that we are collectively acknowledging to each other that we have embraced this community forming narrative and the community the narrative has formed.

In both dramas we embrace Christ; conceived in the womb of Mary, crucified under Pontius Pilate, and resurrected on the third day. Both bring meaning to our own births and deaths, and to our sufferings in between. In both we embrace a suffering, broken, bleeding, dying Christ as we anticipate final resurrection and consummation. Both serve as a reminder that we are still subject to "the bondage of corruption" even though we are also in the blessings of covenant. Both acts remind us that our Lord still bears the scars placed on Him by humanity which moves us to recall that He still is, and wants to be, known as the 
crucified Christ who fully identified with and came to serve His people through suffering and death. In both we embrace the passion of our Lord, which reminds us, painfully, of our depravity and the price that Jesus paid to bring us into covenant relationship with God. But they also remind us of our created dignity as His image bearers whom He considered worthy of that price. Further, Jesus deliberately and decisively places this memorial meal in the context of the "new covenant," concluding with the anticipation of His return which means the final reverse of the curse and restoration of creation at the consummation of all things.

Both acts end in the hope of final consummation; they culminate in pleasure as we celebrate his overcoming of sin and death and anticipate the promise of His return and our resurrection to His very presence and likeness. Both begin in pain and end in pleasure, and are proclamations of the Gospel of Christ, the center of God's redemptive Story in Whom all history is "summed up" (Eph 1:10). Both are sober reminders that we are proclaiming this Story as ours and publicly dedicating ourselves to live a life "worthy of the gospel."

Although HBC teaches about these two ordinances in the classroom, they certainly are in no way confined to the classroom. These two worship dramas are performed regularly at $\mathrm{HBC}$, as in most local congregations, and afford fruitful opportunities to remind the congregation of our dignity, depravity and deliverance and how these bear upon our own conceptions, lives, sufferings and deaths; our bioethical stories. "By confining our attention to bioethics to educational classrooms, we miss a huge opportunity not only to educate people but also to help them connect bioethics to their life of faith in Christ" (LCWE 2004, 
18). There may be no greater opportunity to make this connection than through the worship of Baptism and the Lord's Supper.

Bibliology. HBC, like any church, has a doctrinal statement and like many churches, it begins with an assertion of its belief in the Bible as God's special revelation, inerrant and infallible in its original autographs, and "the product of the verbal, plenary, inspiration of God." Consequently, the Scriptures are "inspired and canonical" and "stand for our final standard for faith and practice" (NC, 25).

This commitment has so much significance for bioethics, especially, as we have seen, Christian moral discernment, which is rooted profoundly in the Christocentric Story that the Bible tells of Creation, Corruption, Covenant and Consummation. Further, insofar as the Bible specifically addresses issues of human dignity, depravity etc. these propositions become "final standards" for faith and practice and thus have significant bearing not only on how we speak bioethically as the church, but that we speak bioethically as the church. A commitment to the word of God as the whole counsel of God cannot ignore its bioethical implications. As Martin Luther famously said,

If I profess with the loudest voice and clearest exposition every portion of the truth of God except precisely that little point which the world and the devil are at that moment attacking, I am not confessing Christ, however boldly I may be professing Christ. Where the battle rages, there the loyalty of the soldier is proved, and to be steady on all the battlefield besides is mere flight and disgrace if he flinches at that point.

Theology Proper. HBC affirms belief in "one living and true God" who exists as "three eternal persons in one divine essence" (NC, 26), and then enumerates a number of attributes. Central to HBC, and historical orthodox Christianity, is a Trinitarian understanding of God. The significance of this for Christian bioethics is that God exists in 
community Himself, and created us, in His image, for community. The sociality of God is reflected in the sociality of humanity, and, as we have stressed, this communal dimension of bioethics cannot be overemphasized. "We image God . . . as social beings. The God who made us is the triune God, whose own life is a story of communal and eternal self-giving, and God made us social. God made us in and for relationships” (Verhey 2003, 163).

Although we could save this part of our discussion for anthropology, it is fitting at this point because the very God we profess to believe in has profound meaning for our bioethical lives. We see the wisdom of asserting this understanding of our God and ourselves "when the project of liberal society would teach us to regard ourselves simply as individuals and our relationships simply as contracts" (Verhey 2003, 163). What we learn from this "theology proper" is that "our relationships with each other are not to be reduced to a set of contractual relationships between autonomous agents. We image God in self giving, in practices of caring for and affirming the existence of the other" (Verhey 2003, 163). When it comes to our responses to people struggling with bioethical dilemmas of conception, pregnancy, suffering and death, what better thing to affirm than God's communal essence as the basis for ours?

Christology. HBCs Trinitarian beliefs, of course, lead directly to the affirmation of Christ as "pre-existent Son of God" Who is "fully God and fully man" (NC, 27). Having dealt with the significance of the Trinity, the focus here is upon the humanity of the second person of the Trinity. HBC states, "Jesus, at the time appointed emptied Himself and took upon himself the form of a servant, the lowest description of man, and became 
incarnate by miraculous conception and virgin birth for the purposes of redeeming sinful men" (NC, 27).

The first thing to note here is that in HBC's doctrinal statement, as in most Christian doctrinal statements, it is impossible to speak of Christ and not tell the Story that serves as the foundation and filter for Christian moral discernment. The significance of Jesus' becoming human has several important implications for our bioethics. God identified Himself with humanity from the same moment that our unique human existence begins; conception. This affirms the dignity of embryonic life and all life in-utero. Each pregnancy we see, and birth we celebrate in church (which HBC does weekly with a flower on the piano; pink and blue representing female and male respectively) can serve as a sacred reminder of Jesus' incarnation. His assumption of human flesh and form from the moment of conception ratifies once and for all that God values embodied humanity from that moment. A case could be made, in fact, that if God could assume the image of man at conception, so does every conceived human being assume the image of God. This is a strong basis, rooted in the Story, for affirming the human dignity and worth of embryonic humans no matter how or where conceived (in-vivo or in-vitro). These observations should play a large, if not central, role when it comes to our discernment regarding contraception, birth control, abortion, assisted reproduction, cloning, embryonic stem cell research, and genetic screening; in short, how we treat the embryonic human.

Although HBC's statement does not mention Jesus' ministry of healing, it is implied, and this, too, affirms the worth of embodied human existence. HBC does state that "He lived a sinless human life and offered Himself a sacrifice by dying on the cross ... he 
was buried and on the third day rose bodily from the dead, alive forevermore" (NC, 27). His exemplary life, as we see portrayed in the gospels, by which we "remember" Jesus, serves as our basis for knowing the heart and values and motives of our Lord so that we can live a life worthy of that gospel. His passion, suffering and dying on the cross, shows further solidarity with us in our human condition, and his resurrection is the basis of our final hope in the Consummation of the Story. Further, insofar as Christ was raised with a body, and He promised us "as I live, you will live also" (John 14:19), we can see, once again, the value of embodied life.

This part of the Story has riches much beyond our awareness for our bioethical discernment. It validates medicine as a profession; a desire to heal human bodies, and restore humans from their illness, injury, disease and disability in imitation of the Great Physician. It affirms the validity of developing technology, appropriately called modern-day miracles, for healing purposes to restore embodied humans to a place of wholeness, not just in their own bodies, but back to the body of their Christian community as well. The whole enterprise of medicine, whether in the research in the lab or its clinical applications, serve as hope-filled reminders, even in the midst of our corruptions and limitations, of the good future to come at the Consummation when God's healing presence will "wipe every tear from our eyes" and death and the curse will be no more (Rev 21:3-4, 22:2).

Pneumatology. The Holy Spirit is the Third Person of the Trinity, again highlighting the communal nature of God who created us as relational beings. The Holy Spirit is the agent of Creation and Revelation (especially inspiration of Scripture). God's spiritual essence is reflected in ours and is the point of contact between heaven and earth, as 
it were, and our knowing God is based on the work His Holy Spirit. The Spirit of God is the very life force that animates us as humans (Job 34:14-15).

Another key observation is that the Holy Spirit resides at every key moment in the incarnation and ministry of Jesus Christ "from His birth to His death and Resurrection" (NC, 28), being the underlying subtext for every gospel narrative. He is also the very empowerment of the Church. He fills us, and illuminates us, enabling us to understand the Story, and to respond to it, "He calls, convicts and regenerates the unbeliever" and gives us gifts enabling us to "teach and admonish one another." Without the Holy Spirit there could be no fruitful bioethical discernment within God's covenant community. Further, when we face our bioethical challenges, the Holy Spirit is there with us helping us with our infirmities, and interceding for us in our sufferings (Rom 8:26-27). Finally, it is the Spirit that is the indwelling assurance and hope that the Consummation, "the day of redemption," of which the Story speaks, is our definite future (1 Cor 1:22; 2 Cor 5:5; Eph 1:13, 4:30).

Angelology. Angels are created beings, like us, who are "ministering spirits" to believers. It may be that they are present with us, as with Christ, in our suffering and need, but the Bible does not speak explicitly to this or how we are to relate to these angels. But one of the important elements of angelology for our bioethics is the presence of Lucifer, or Satan, the fallen angel who "now uses his gifts and abilities to oppose God at every level and by every possible means" (NC, 29), and employs legions of wicked spirits as his minions "to assist in his scheme" (NC, 29).

As we saw above, Satan is the primary agent behind our corruption. Satan's seductions of humanity to oppose God, by grasping for their own godhood and determining 
good and evil for themselves, continue to this day and we must "not be ignorant of his devices" (2 Cor 2:11). We must recognize and resist the ever present temptation, especially in our biotechnology, to grasp for autonomy and self-determination under the great delusion that we can somehow save ourselves from, and thus definitively reverse, our depravity and death.

Anthropology. "We believe that man came into being through the creative act of God" (NC, 30). This simple affirmation has incredible ramifications for bioethics. First, as soon as anyone speaks of humanity's origins, whether naturalists, postmodernists, pantheists or theists, they will necessarily tell a story. So even in a doctrinal statement, drawing on biblical revelation ratifies that our theology, our worldview, is narrative in nature. Humans are created beings, here by design, not mere accidents of the impersonal forces of nature or spirit, and according to the Story are "the crowning part of God's creation, in that he was created in the image of God and given dominion over all the rest of creation" (NC, $30)$.

As we have seen, the worth and dignity of humanity rests on this presupposition of having been directly created by God and in His image, and is an irreducible orientation of Christian bioethical discernment. We have also discussed the significance of human dominion as a justification for the development of technology in a way consistent with God's creational purposes. Further “man's nature is material, the body, and immaterial, the soul and spirit" (NC, 30). This affirmation is important for a biblical bioethics because it accounts for humanity in a holistic way, and should orient us to attend to whole selves, and reject "genetic reductionism and determinism" (Verhey 2003, 164). For bioethical issues we 
must assert that "we must not be reduced either to our genes or to simple transcendence over them" (Verhey 2003, 164) which is the alluring thought of today's secular bioethics. If we can manipulate the human genome, it is thought, we can change humanity, and although this is thought to be for the good, it, in many ways, is operating under the delusion of our corruption and grasping for autonomy opposed to God. Pure genetic reductionism is the ultimate threat to human dignity. The Story screams loud and clear that we are much more than the sum of our parts, and is the only story that actually validates this position, because it tells us precisely what that summation is-the imago Dei.

HBC further affirms that humanity "fell from [its] original state of perfection through willful disobedience. As a result his nature was corrupted, death was introduced to the world and the sin principle was passed down to his posterity" (NC, 30). Here, HBC moves, quickly, as does the biblical narrative, from creation to corruption and how the consequences of the latter have affected every human ever born since that time. The significance of these statements and beliefs are important for Christian bioethical discernment, as we have seen. It is because of the fall of humankind, original sin, that bioethical questions have become necessary in the first place since the fall brought death (Rom 5:12) and all its accompaniments—disease, disability, dying and decay—and thus raised the need for medicine which calls for bioethics. We live in a world which groans in anticipation of its final restoration (Rom 8:18-25).

Hamartiology. HBCs doctrine of sin centers on the continuation of the "sin principle" in human experience since the fall. The purpose of this declaration on HBC's part is no doubt to establish the need for salvation through Christ's death on the cross, but as we 
discussed above, the reality and pervasiveness of human depravity is an important truth with which we must reckon and wrestle in our bioethics. Our sin nature tends to distort all our ethics, moving us to grasp selfishly for our own goodness, however we define it since we, in our corruption and grasping for godhood, have forsaken God's definition of goodness. An important note from HBC's doctrine of sin is that "Those who believe in Christ are justified of their sin but sin is not dead in them until it is removed in their glorification" (NC 31). The perpetuity of sin as a principle asserts that all humans possess a nature opposed to God and His will. The human heart is corrupt to the core and ultimately unfathomable as to the evil it harbors (Gen 8:21; Jer 17:9). This reality is ever present with us even when we purpose to do moral good (Ecclesiastes 7:20; Romans 7:18-21).

This recognition should bring us a sense of pause while discussing bioethical issues because our sin nature moves us away from submission to divine authority and toward self-determined autonomy; as we have said, a grasping for godhood in the sense of determining right and wrong for ourselves. The former, submission to divine authority, can lead to wonderful (bio)technological developments that affirm human dignity, and relieve human suffering, in imitation of Jesus, while the latter can, and historically has, resulted in great evil as humans who are innately greedy, ambitious and self-serving use technology to control and manipulate others with an "ends justifies the means" utilitarianism. True ownership of this evil propensity should make us humble, teachable, vigilant, reflective and cautious when it comes to applying information and technologies that are available and at first glance look like they do great good. 
Soteriology. "All of mankind needs salvation" (NC, 32). HBC's doctrine of salvation affirms that salvation is wholly the work of God's mercy and is completed "apart from works" and is "sufficiently provided for all mankind through the death of Jesus Christ on the cross but efficiently applied only to those who believe" (NC, 32). Salvation is the work of the Trinity, and a saved person has been "justified," is being "sanctified" and will be "glorified." All of the doctrine of salvation, in HBC's statement, centers on the gracious work of God in behalf of sinners to redeem, reconcile and regenerate them. As we have seen, this work of Christ is the culmination of the Story the Bible tells. Salvation is a present reality and a future promise for the believer.

Ecclesiology. According to HBC, the church is both universal and local. Universally, it is the body of Christ composed of all those who have been "born of God's Spirit" and "baptized into the body of Christ" (NC, 33). Locally, it is a "called-out living assembly of baptized believers associated by a covenant of faith, organized by New Testament principles, assembling regularly together, led by qualified pastors who are supported by qualified deacons, under the discipline of God's Word and the Headship of Christ, and observing the ordinances" (NC, 33). A community of those who are in a covenant relationship with God and each other through Christ under the discipline of God's Word is the essence of the moral community we have articulated above in detail. We have also stressed the communal importance of the ordinances.

Eschatology. HBC's discussion of "last things" centers on the sequence of the end-time events unfolding from the time of the rapture. It does not really highlight the elements of cosmic consummation we have stressed in this project. Nevertheless, their 
simple statement that "the saved will spend eternity with God" (NC, 34) draws attention to our finally being "delivered from the bondage of corruption into the glorious liberty of the children of God and the ... redemption of our bodies" (Rom 8:21, 23) and the healing presence of God in the New Jerusalem (Rev 21:1-7). Its presentation of the end time sequences however, does draw attention to the narrative nature of biblical revelation, even when talking about the consummation of all things.

Distinctives. Following its doctrinal statement HBC discusses its "Baptist Distinctives" and then its own "Heritage Distinctives" (NC, 35-36). We have already considered the centrality of biblical authority and the two ordinances for our bioethical discernment, which represent the "B" and first "T" of the acrostic BAPTISTS used to delineate the "Baptist Distinctives" to which HBC ascribes. The "A" represents "autonomy of the local church" and on this premise, HBC has established its "Heritage Distinctives," also articulated as an acronym for H-E-R-I-T-A-G-E which have great significance for bioethics, as we will see. $^{25}$

The first Heritage distinctive is the heart of HBC's passions toward family and world evangelization. Family is an important part of God's creative order and design, as we saw above, and the whole experience of family, from conception to child bearing and raising has incredible bioethical significance. Especially in light of new powers of

25

This point of affirmation of autonomy should not be confused with the individual autonomy critiqued above. HBC is a self-governing body independent from any higher organizational hierarchy, meaning that as an autonomous community it can develop its distinctives based on how it understands Scripture, and thus not be governed by a higher authority which may not interpret Scripture correctly. 
reproductive medicine and those on the horizon, men and women are being given increasing control over when to become parents and how to become parents. The technologies that broaden these reproductive freedoms must be brought under the scrutinizing eye of the Story, and the whole process of Christian moral discernment as does all our family life. An important element of raising children is to transmit the story of God's redemptive love to our children for their understanding, as ancient Israel was charged to do (Deut 4:9, 6:1-9), and was implied in Timothy's family ( 2 Tim 1:15, 3:15). Hopefully, an emphasis on the Story from the pulpit and in classrooms will illumine the power and significance of the biblical framing of human existence in Creation, Corruption, Covenant and Consummation to our young, in hopes that they will learn, and even "own" early what it means to live a life "worthy of the gospel of Christ," through home instruction and the worship and teaching of the church. $^{26}$ As to world evangelization, essentially, as we saw in chapter one, bioethics, rather than drawing away attention from evangelism, actually provides opportunities to make connections with needy people facing crises in life that a relationship with God through Christ can inform and transform profoundly.

26 Interestingly, Budziszewski observes, in an essay dealing specifically with how to "keep" our children when they get ready to leave for college, that the first two things students need to hear from their church leaders is that the Scripture emphasizes not "the solitary believer but ... the community of faith" and, secondly, they need to hear "about the 'big Story' of Revelation” (Budziszewski 2003, 108-109; emphasis mine). On this latter point, he opines, "Although young Christians know "Bible stories," they often fail to realize that the Bible as a whole is a single great story - the true story, with extensive commentary, of God's dealings with humankind" (Budziszewski 2003, 109; Emphasis his). His contention is that we will more likely keep them from straying if we teach them these two critical elements of biblical faith: 1) that they are part of a community and 2) the narrative nature of revelation! 
HBC's second distinctive, expository preaching and teaching, is rooted in the conviction that it is through God's word that "lives are changed and faith is grown" (NC, 36). A commitment to "verse by verse" preaching and teaching may, at first, appear not to conduce to regular reference to bioethical education, but as pastors and teachers become more immersed in the Story and exercised in the skill of moral discernment, the bioethical significance of God's Word will be seen all over the place, because each proverb, psalm, precept, prophecy and narrative of the Bible ultimately takes its meaning from and points to the whole Story (Verhey 2003, 59). Instead of making every sermon and lesson bioethical, per se, pastors and teachers can use the bioethical challenges and stories of their congregations to illustrate the Story and in many cases, on the part of the members in their stories of conception, pregnancy, birth, illness, disease, dying and death, faithfulness to living a life worthy of the gospel.

HBCs third distinctive, its reason for being, is a commitment to its four-fold purpose, to be discussed in the next section.

$\mathrm{HBC}$ seeks to be "innovative" (NC, 36). Ministering to people may require that "we come to some creative solutions" $(\mathrm{NC}, 36)$. What guides the commitment to doing new and different things are the core values that "people matter to God, people need to be cared for and the pursuit of excellence in everything we do." (NC, 36). That people matter to God and need to be cared for is conspicuously relevant for bioethics, thus innovative ministry is necessarily going to include bioethical education, especially in this biotech age when the very object of these medical innovations is humanity itself. Insofar as Jesus merged medicine (healing) with ministry, so should the church. 
HBC is also committed to a "teamwork approach" to ministry. This views the purpose of leadership as those who train and equip God's people to use their gifts in ministering to one another (Eph 4:11-12). As HBC seeks to help members discover their gifts and place of ministry, a theme of bioethics will provide another place for ministry involvement in the church, and this may raise up individuals with a passion for the process of bioethical discernment.

Adult Bible Fellowships are what HBC calls its Sunday school program, especially for adults age 18 and up. It enlists and trains lay "shepherds" to oversee small group ministry and shepherding of the flock of God. The pastoral staff of HBC understands their limitations in ministering to such a large body of believers, and the largeness of the local church calls for such a ministry to more effectively cultivate a sense of belonging and becoming. This setting is ripe with opportunities to address and cultivate Christian bioethical discernment, because the needs that arise in the lives of families and individuals in the areas of conception, birth, pregnancy, illness, disease, dying and death call for ABFs to address them, and to concretely minister to the people in the time of their needs.

Growth through discipleship is the next $\mathrm{HBC}$ distinctive, and involves a commitment to "help and see those of our congregation grow and mature in their faith" (NC, 36). HBC envisions that this will result in "personal and corporate growth . . . [and] each member's total commitment to God in their spiritual walk" (NC, 36). It is hard to see how such a vision could exclude, even by default, bioethical education. It would seem that a commitment to God involves a commitment to His Story and its implications for all areas of our lives from conception to death. 
HBC has also instituted its "electives for equipping" in the Life Training Electives. HBC has already allowed, over the last five years, for a thirteen-week adult elective taught by this writer specifically dealing with bioethics. Heretofore, there has not been an emphasis on the Story and the process of Christian bioethical discernment as outlined above. The fall elective planned for this fall will specifically address these issues under the title "A Story to Love, A Story to Live: Biblical Narrative Moral Discernment in the Church."

Purpose. HBC's fourfold purpose is rooted in the Acts narrative depicting the earliest communal disciplines of the early Christians (Acts 2:41-42), and entails evangelism, edification, worship and fellowship. This purpose serves as the criterion for the planning and evaluation of all ministries in the church. Being HBCs raison d'etre it is the explanation for “why we do what we do and why we don't do what we don't do.

The first of the fourfold purpose is evangelism, making known the good news of Christ to neighbors and nations. The church not only witnesses to the Gospel in powerful ways through its bioethical message, as we have seen, but it also communicates clearly how this Story relates to the daily life and concerns of all people thus providing points of contact for the gospel message. If the church does engage in bioethical discernment it can demonstrate the relevance of the Gospel in innovative and relevant ways that can renew a commitment from the members to tell the Story.

Edification means literally to "build up" the goal being to see the congregation "established in faith or attaining unity of faith and knowledge, maturity and the full measure of Christ" (NC, 38). "Unity of faith and knowledge" would definitely find place for 
communal education and ownership of the Story, and "maturity" and the "measure of Christ" has everything to do with living a life worthy of the gospel of Christ, as we have articulated. Edification and discipleship, of course, go together, and it would seem a neglect of spiritual duty not to address bioethics to bring members to "become fully devoted followers of Jesus Christ" (NC, 38).

HBC calls fellowship, the third purpose, "the bond of common purpose and devotion that binds Christians together and to Christ" (NC, 39). Common purpose, of course, is rooted in corporate ownership of the Story and especially God's covenant heart. The more we immerse ourselves in that narrative that forms and transforms our community, the more we will understand its power to transform our stories together. Fellowship in the New Testament involved far more than meeting together, but working together to meet the needs of the most vulnerable among us and to care for each other in our times of suffering, death and dying. Bioethics and body life are inherent to what it means to have a church committed to fellowship. ABFs, as mentioned above, are HBC's mechanism for "organizing shepherding and care [fellowship]" in the local church.

Worship is the final purpose that HBC articulates. They describe worship as "human response to the perceived presence of the divine ... of holy presence. The response may take many forms" (NC, 40). The Lausanne committee has summarized the significance of worship for bioethics as follows.

Praise, thanksgiving and confession in congregational worship rarely have much connection with bioethical challenges such as biotechnologies threatening unborn human life or the prolonged dying of elderly people, but that need not be the case. Praising God for His creativity in crafting human life in all of its genetic complexity is perfectly appropriate. So is thanking God for defeating death on the cross so that 
we need not fear dying. Confessing our self-centered disinterest in helping others who have chosen to keep rather than abort a disabled child is appropriate as well.

The ministry of prayer in the church is particularly vital to those who are struggling with issues related to bioethics - the childless couple considering artificial reproductive technology, the pregnant single mother considering abortion, and the terminally ill patient contemplating suicide. Although prayer may not always change their situation, it may give them the wisdom and the moral courage to choose obedience. (LCWE, 18).

Corporate worship, from this perspective, provides a rich resource for drawing attention to our Creator, as well as our creatureliness and utter dependence on our Creator for our lives. As we have already considered, too, there is profound bioethical significance in baptism and communion, both acts of communal celebration of life, the gospel and the life to come.

ABF Classes. $\mathrm{HBC}$ shares about the history and reason for adopting the $\mathrm{ABF}$ approach to adult Sunday school. An ABF is specifically defined as "a group of believers committed to knowing and applying the Word of God together in caring fellowship and organized to bring about shepherding care, discipleship and outreach" (NC, 41). Much has already been said about ABFs above, as a venue for meaningful bioethical education and discernment, but one emphasis which has not been underscored yet is that these are one of HBCs vehicles for outreach and evangelism. Each ABF is envisioned as a place for "open discussion centered on the Word of God as it is applied to the circumstances and situations of life (NC, 43 Emphasis mine). The point here is that as we bring non-Christians into exposure to the church, they can see how the Bible, by way of its Story, addresses issues relevant to their experiences of conception, pregnancy, birth, health and sickness, disease, disability, death and dying. As ABFs address bioethics from the perspective of the Story, non-Christians will be exposed in powerful ways with how God's truth connects with their bioethical struggles. 


\section{CHAPTER 3}

\section{NARRATIVE REPORT ON FIELD WORK}

I approached Dr. Jerry Kroll, Senior Pastor of Heritage Baptist Church in Lynchburg, VA, about using HBC as the milieu for my field work. I requested, first, to teach the 13 week elective again in the fall of 2007, to which he agreed. But not only did he do this, he also suggested that I could do a four part sermon series in January (Sanctity of Human Life Month) 2008 on bioethical challenges facing the church.

\section{Narrative on Methodology and Project Execution}

I carried out the project with specific methodology. I will first explain what I did in a general sense, and then discuss more specifically what was involved in the process.

\section{General Considerations}

Following the elective, I did a focus group with the attendees on the last day, but really, each week was a focus group in a sense, in that I arranged for a lot of discussion which, in turn, led to my receiving important feedback almost every time we met. I also did a before and after survey of the congregants who attended for the first and last sermons of the four part series.

I set out to achieve four basic goals with this project. First, to make a case for the urgency of educating the local church about current bioethical issues, second, to demonstrate how a church's doctrinal tradition may serve as the framework for addressing 
bioethical challenges, third to educate the congregation concerning specific, relevant bioethical issues and biblical responses to them, and, finally, to lead selected individuals in exploring how the church can further encourage bioethical education in the church. I broke these goals down into seven objectives, which I will articulate below as I present the narrative of the project's execution.

\section{Specific Applications}

In my discussion in the remaining chapters I will refer to each goal listed above by its respective numeral, G1, G2, G3, or G4, and I will use the goal number with the lower case letter ( $\mathrm{a}, \mathrm{b}$ or $\mathrm{c}$ ) to designate the goal with its objective, and how the methodology was used to achieve said goal. ${ }^{27}$ I will abbreviate my methodologies as follows: (1) "LTE" to indicate the 13-week Life Training Elective I taught in the fall of 2007, (2) "M" to indicate the 4-part series of messages I preached for both the am and pm services on Sunday, January 13 and Sunday, January 20. I will designate individual messages as M1, M2, etc., and (3) "S" to indicate the Surveys I administered during the a.m. service on January 13 and the p.m. service on January 20; particularly, S1 the first survey and S2 the second.

\section{Life Training Elective}

Heritage Baptist Church, instead of a traditional Wednesday night prayer meeting, holds what they call "Life-Training Electives" (LTEs) each spring, summer and fall. These classes are designed to provide adults the opportunity to grow in their Christian lives and become more fully equipped for ministry in a group setting. I have been leading a LTE

${ }^{27}$ For a reminder of this project's goals the reader is referred to chapter one. 
for several years, and normally sought to guide people in understanding bioethical issues and how the Bible bears upon them. My goal was that the attendees become informed, informative and involved at whatever level God would lead them through the material presented.

This time, however, in light of the project and my research, the 13-week elective served a two-fold purpose. While I definitely wanted to teach attendees the concept of using the biblical narrative for doing bioethics as a moral community, I equally wanted to learn from them what they thought about bioethical education in the local church and especially how they thought it should be done. I introduced the attendees to the project and how they can help me in my research. They gladly filled out the Informed Consent form so that I could use their comments in my report. ${ }^{28}$ I distributed the syllabus and briefly explained the course description.

The LTE started in August, 2007 and carried through December, just prior to Christmas. The title was "A Story to Love, a Story to Live: Ethical Decision-making in the Light of Biblical Narrative." The description of the course read in the bulletin and on the webpage as follows: 29

Description: In this elective we will explore together what shape our thought and lives might take as people striving to be faithful to God in view of current bioethical challenges. We will explore issues which have emerged and are emerging due to new medical knowledge and powers that promise increasing levels of control over our

28 See Appendix 1 for this form.

29 This description also appeared on the syllabus which I distributed at the first meeting of the LTE. This, as well as all other handouts mentioned in this discussion about the LTE, has been included in Appendix 5. 
procreation, health, sickness, suffering, aging and dying. We will work to discern a response that reflects biblical faithfulness in these critical and common experiences of life. Recommended Reading: Holy People Holy Lives by Richard C. Eyer

I based this title and course description on the research emphasis for this project. My research, as I explained in chapter one, led me to conclude that framing bioethical issues in terms of the biblical narrative would be an effective way to bring the community of God's people, regardless of their educational background, into the discussion on bioethical issues, and thus an efficient way for conducting bioethical education in the local church. Each Wednesday night I met with a group that averaged about 20 adults from various backgrounds; home-makers, educators, business owners, two disabled men (one wheel-chair bound), retirees, writers, an Emergency Room physician, two Registered Nursess and one nursing student, etc. We started at 7 p.m. and went through 8:30 p.m. From 7:007:30, we prayed over the list, and from 7:30-8:30 we had class. In this LTE we engaged not only bioethical issues as such, but also the issue of bioethics and how to educate the local church in this area.

During the first session, I sought to start meeting goals G1a and G1b by directing discussion around what they understand the term "bioethics" to entail (See Handout Two; Introduction, Bioethics and the Local Church). I especially tried to discuss it in terms of making decisions about how to use the biotechnologies that are and are becoming available to us that will help us to take increasing control of our procreation, health, sickness, healing, aging, dying and death, as stated in the description. I also directed them to the statements from Peter Singer and Robert Haynes and their respective ridicule and reductionism with regard to the concept of the sanctity of life and human significance. Then, 
in light of quotes from Fukuyama, Kass and McKibben, addressing the urgency of the bioethics task, they realized that the church had a "huge responsibility," as one attendee put it, to address these issues. They essentially concluded that if these ideas continue unchallenged, they are going to shape the culture by default and whatever happens in the culture influences legislation, and legislation influences us. So we must be concerned. This met G1a by showing them the urgency even from the perspective of secular thinkers. Based on what these attendees already understood, and the fact that many of them had attended electives I held prior to this project, they knew that the basis for our concern lay in the biblical truth that humanity has been created in the image of God, and that we should care deeply about how these biotechnologies that give us control over the various life-stages impact human dignity.

Session one spilled over into the following week so we really did not complete the material planned for session one for two weeks. Week two, however, was a very fruitful discussion. Over-all, the attendees felt that the church in general has been too "silent," "incompetent," " uninformed" and has its "head in the sand" with regard to bioethical issues and that we would increasingly lose influence if the church continued to ignore addressing these issues. They also were grateful that HBC, and in particular Pastor Kroll, is not opposed to addressing such issues and allowing a class like this, but did bemoan the fact that more people were not in attendance, and that more churches were not addressing them.

The group concluded that we are hearing about bioethics only from the media and are thus poorly equipped to address and deal with the issues ourselves. Consequently, 
while we need experts and "intellectuals" to deal with the issues and communicate to the church, Christians need to be given a way to process the information from the media themselves. This made for a nice segue to bringing up the matter of using the biblical narrative as the framework for bioethical discernment as God's community; the last point of discussion for session one.

But the point was also brought up that Christians probably shy away from bioethics because it is perceived as an academic subject, and intellectual exercise. "We don't think critically" said one, and "we don't know the questions." Further, the point was made that bioethics may deter us from our priority of evangelism and get us embroiled in the culture wars. Finally, there was the matter that we may be afraid to deal with bioethics because it surfaces very personal issues, and there may even be fear in having to deal with how we may have tried to justify past behaviors. In light of these points, I thought about my section in chapter one dealing specifically with objections and thought that it would be appropriate and timely to address them, so I planned an "addendum."

On week three we discussed an "Addendum: Answering Objections to Bioethical Education in the Local Church (See Handout Three)." The group responded well to this section, and had much to say, especially when we got to the objection about bioethics being too personal. This made sense to them, and one lady even ventured to share a story about how she had to make a difficult decision when her granddaughter, whom she was raising, became pregnant as a teen. She admitted "You are tempted, even when you have heard it in church so much, to go through with it when you think about the impact it can have on her future." At this point, she gained sympathy and praise from the group. I shared a 
video clip I found on Wingclips.com of a scene from the film Hidden Secrets where a woman in church confessed to having had an abortion and how another woman was condemning abortion, abortionists and women who obtain them. The post-abortive woman was ready to leave and said, "I guess I don't belong here," but a young man stood up, pronounced his own mea culpa and quoted 1 John 1:9 in a powerful example of how the church should be redemptive with people who have failed bioethically in the past. I spoke of how we, the body of Christ, need to be prepared to be redemptive when stressing bioethics and especially based on a sanctity of life ethic as it will surface guilt in the congregation. This point has frequently led to more confidence in confessions where the group can then speak redemptively and healingly to those who share. This is an important lesson which I will talk about more below.

On week four, I began Session Two. I began articulating the biblical framework, thus the metanarrative, for doing bioethics in the church (See Handout Four: "Story" and Community as the Context for Bioethical Discernment). Upon asking whether it was a generally good or bad idea to speak of the Bible as a "story," some in the group initially objected because they equated the word with its connotation of fictional tale, in contrast to that which was "historical." When I explained its denotation and etymology as an abbreviation of "history," how it evolved to the connotation of "a fictional tale told to entertain," demonstrated that we still often use it to describe true and personal events, and that news programs and media use it to describe factual accounts ("story at eleven"), the lights did seem to go on. I further explained how appealing to the narrative nature of the Bible can show its relevance in this postmodern generation. I also drew the contrast of how 
post-modernism, while celebrating the personal narrative, denies the metanarrative. Further, when I called attention to how the Bible is predominantly a narrative about the interactions of God with His people, and how the Bible, according to recent scholarship (Carson 1996 and Sire 2004), presents us with a metanarrative, the group seemed to understand where I was going with this.

So I moved to talk about how the biblical narrative could and should be, the "story we live by" (Sire 2004, 102). I illustrated this with a video clip from the Pirates of the Caribbean (2003). In this popular Disney film, a female character came across a Pirate's medallion as a child. She kept it many years and cherished it. By the time she was an adult, she still had no idea of its significance or the bigger story surrounding it. The pirates seeking the medallion caught up with it, and her, and revealed to her this "bigger story." It was one of many medallions stolen from a treasure chest by greedy pirates. This act had angered the pagan gods and they were consequently "cursed men," never being able to die or to feel the simple sensory pleasures of life until all the medallions had been returned. The woman, who possessed the last one, said that she "hardly believed in ghost stories." Soon after, she realized that this tale was true, and that she had "best start believin' in ghost stories . . you're in one." I have used this to illustrate how we humans are part of God's big story, whether we realize it or not, whether we believe it or not, and that we had 'best start believin' in God's story, we're in it!' I also explained how every subsequent decision following this realization of the bigger story she was caught up in, was made in light of that realization, and her owning the fact that this was now her story, and her life and well-being depended upon it. Likewise, once we truly own the big story of the biblical metanarrative, our every decision in 
life should be made in light of this fact. All but one attendee seemed to see this as a powerful illustration, particularly because he did not care for the movie.

I then drew the connection between how God's people needed to own the story they were a part of and how their ethical lives were to be lived out in light of this reality. When I illustrated this from Exodus 20:2-3 and 8-11, I saw people accepting this concept more. In fact one man in attendance actually said that this is what made the most sense to him, to see how the context of the ten commandments, particularly the Sabbath law, was rooted in the narrative of God's redemptive acts with Israel. He later told me how this perspective helped him see other ways, not just in bioethics, the "story" of Scripture enhanced his life and how he interacted with and taught his own children. The poetic framing of this concept by author Steven James, “Ah, sweet story teller, speak your tale into my heart so that my life might finally make sense" (James 2006, 85) led one lady to remark that seeing the Bible this way gave her a sense of "hope" because she knows how the (her) story is going to end. We also started talking about the community context for our ethical reflection, which prepared us for the following week when we started session three. We started discussing the articulation of the biblical metanarrative itself on week five (See Handout Five: Living the Story Together Communal and Biblical Discernment in Bioethics). Although this was familiar ground for most of the attendees in that they have been taught the concept of worldview, though not necessarily framed in terms of Creation, Corruption, Covenant, Consummation and Christ, seeing how the five motifs or megathemes could be specifically tied into our bioethics was a little more challenging. I asked the class, after discussing each major motif, to make specific applications to bioethical issues under them. 
The purpose of this exercise was to begin to fulfill G2a and G3b.

This was challenging, but as I shared more from my paper, it appeared that they began to see the relevance of such a framework for our bioethical task. They could definitely apprehend the relevance of Creation. They understood how our bioethics begins from the conviction that God creates us in His image and likeness, and made us to reflect this image in our "dominion" and technological pursuits. Biotechnology, they agreed, was consistent with the Creation motif. As for the Corruption, while quick to realize that death and the dying process, the physical consequences of our corruption to which a lot of our biotechnology is directed, is relevant to this motif, they were a little slower to see how the moral effects of depravity had a bearing upon our bioethics. As I articulated the matter of depravity, I demonstrated how the Corruption motif also speaks of our "sinfulness" which draws us away from utilizing technology to glorify Him and uphold His image in human life, and to ignore and even desecrate that image. They were then able to discuss in much more detail and enthusiasm how biotechnology has both "promise and peril," and how this raises, again, the importance of educating God's people on bioethics as a part of the church's educational task.

On week six we finished up discussing the biblical narrative (Covenant and Consummation) and then began discussing the idea and process of church as a moral community (See Handout Six: The Practice of Bioethical Education in the Local Church). Here we started into the heart of the elective; the importance of our working together as a community to discern God's bioethical will by way of discourse, deliberation, discernment and decision. Our focus, however, was on imaging as imitating, and discussed how God and 
especially God incarnate in Christ — the Gospel—is the center-piece of the biblical metanarrative, and the ultimate standard for the community task of our bioethical discernment. At this point, one lady was concerned that we were "redefining" the gospel to include the whole creation story, etc. She seemed to be fearful that we were taking liberty with the gospel, which she identified as the "death, burial and resurrection of Christ," in saying that the whole of Scripture was the gospel, thus divesting it of its unique and proper place. But when I explained that the megathemes are not, in fact, the gospel, per se, but are the historical antecedents and future anticipations that make the Gospel, the heart of the narrative, intelligible, she seemed to accept that.

At the end of discussing the "4-D" process, I sought to lead the class in applying it to a specific issue. I handed out a brief narrative, copied from the Lausanne Occasional Paper about a couple seeking to start a family by considering not only in-vitro fertilization (IVF), but also sex-selection and Pre-implantation Genetic diagnosis (PGD) (See Handout Seven: Practical Exercise). I asked them first to isolate the "hot points" in the story. With this, we limited our discussion to the "discourse" phase and concentrated solely on identifying the issues that emerge from the story, and why they are issues in the first place; particularly in light of the fact that this couple was apparently Christian. We got to discussing the problems with Assisted Reproductive Technology (ART) and had to end there, due to time. The class seemed ready and eager finally to apply the process!

In week seven we picked up on the story about procreation we started with and as we came to the deliberation and discernment phases of the 4-D process, we hit a snag. I had handed out "Procreating in His Image, and Ours (See Handout Eight)" to provide some 
of the biblical story line as the basis for our discernment and the question came up about how sure we can be that human life really begins at conception. This actually began, I am sad to say, the unraveling of the elective, and this is where I learned an important lesson.

I would say that when presenting the bioethical content of the Scriptures in this 5-C framework, there can be a lot of assumption to begin with on the part of the teacher that the congregation is comfortable with this. This may not be the case, as I learned. I thought we were ready to proceed. It was obvious that I would not get through the entire syllabus as planned, but I had no idea that we were about to get hung up on procreation issues. The discussion about procreation and the raising of the questions about procreation led the class to a more fundamental concern about the human embryo. Admittedly, I let myself get sidetracked, but I felt that this is where the class was, and that they needed to revisit this foundational question. I will evaluate this more deeply in chapter five.

So the next week, week eight, I handed out fill-in-the blank notes from my college class addressing issues at the beginning of life (See Handout Nine: Issues at the Beginning of Life). I sought to explain why the question of the moral status of the human embryo is important in light of such current biotechnologies as artificial contraception, the morning after pill, abortifacient drugs, assisted reproductive technologies, pre-implantation genetic diagnosis, embryonic stem cell research, and "therapeutic" cloning. We slowly discussed the science of these technologies and their bearing on the question of the embryonic human, as well as the conclusions we can make about when human life begins based on the testimony of numerous embryologists. The question was brought up about 
what the Bible really says, and that this is most important in regard to this question. So this set the stage for the following week.

On week nine, I went through some of the traditional passages concerning the biblical view on pre-natal life, and then began presenting a more philosophical argument of why "the defense of the human embryo is the defense of the human race." To make this case, I presented the views of Peter Singer concerning the human embryo, and how while he does not deny that the human embryo is in fact "living" and "human," he does deny them the status of personhood due to their lack of criteria such as self-consciousness, and future orientation (Singer 2004, 34-44). I received some objections from a college professor in the group who did not think I had really made the case. He concluded that it is completely and totally a matter of faith to believe that human life begins at conception; there's no way to prove it. Not everyone agreed, and another man, wheel-chair bound due to his disease, came to me privately and said that this is so important to understand because people like him could be considered non-persons based upon their lacking particular criteria. Most of the class saw my conclusions quite tenable, it seems.

This led us to week ten in which I handed out a critique I had written on Peter Singer and how his views on infanticide were actually most consistent with the conclusion that personhood does not begin at conception, and how he himself teaches this (See Handout Ten: Essay). From here, I demonstrated how his views about abortion and infanticide were consistent with the mentality of euthanizing certain people who had lost the capacities of personhood later in life. The class could see this. Even the professor who objected in the first place could see, philosophically, how Singer's views about the human embryo served as 
a basis for euthanasia. Although he did come up to me following class to tell me that I could have the bioethics stuff, and that he will take the "certainty" of his mathematics over bioethics any day. In this presentation I also discuss common secular objections to the belief that an individual's human life span begins at conception at which time they are also persons.

Week ten's discussion also spilled over to week eleven where we finished up dealing with the objections, and now we were far from finishing the syllabus as planned. I acknowledged this to the class, and they really did not seem to mind, and were pleased with how we were covering some of the more fundamental issues. They also said there's always next spring, suggesting that we continue the class into the next year.

So for week eleven I decided to address the issue of abortion, still connected to questions of procreation, and handed out an essay entitled "Nine Reasons Why Abortions are Legal" written by the staff of Planned Parenthood (See Handout Eleven). I wanted to show how the pro-choice argument, at least as presented in this essay, was fraught with logical fallacies. I wanted to build up the class's confidence in the pro-life position even more by showing them what the opposition had to offer as their arguments. The professor who teaches mathematics and logic noted that if a student handed in a paper with this kind of fallacious reasoning, he would fail them for the course! This was a fruitful and worthwhile discussion.

We spent week twelve discussing matters of good faith versus bad faith in the abortion issue (See Handout Twelve: Good Faith and Bad Faith in the Abortion Debate). I am indebted, once again, to Allen Verhey for the discussion of good faith and bad faith (Verhey 2003, 194-216). I find this to be an important consideration in our fight for the 
unborn. He describes how both sides of the debate often do not honestly admit the difficulties with their own positions on matters of the moral status of the unborn, the needs and claims of the woman, and the value of human life. This turned out to be a quite useful discussion as well, and a warning for us, as pro-life advocates, not to ignore some of the difficulties with our own position.

We finished up matters of good faith and bad faith on week thirteen and then went to the focus group in which I encouraged them all to evaluate the course verbally and to deal more with the question about how the local church should go about the task of bioethical education. I will address these matters in detail in chapter four.

\section{Sermon Series}

My focus in the sermon series was to discuss bioethics in terms of issues at the beginning of life and the end of life. I knew that no matter what I said, I was only going to scrape the tip of the ice-burg since each lesson, I was told, could be no longer than 35 minutes maximum.

I used Isaiah 46:3-4 as the overall theme passage for the series. I entitled it "Carried all the Way: Godly Decision-making at the Beginning and Ending of life.",30 The church staff began promoting the series on Sunday, January 6. The series began Sunday, January 13 and concluded on Sunday, January 20; Sanctity of Human life Sunday. I spoke at both the a.m. and p.m. services on these two consecutive Sundays. On the first Sunday, M1 and M2, I focused on seeing God at work in the human life span and issues at the beginning

${ }^{30}$ All four sermon manuscripts from this series are included in Appendix 6 . 
of life, and the second Sunday, M3 and M4, I devoted to end of life matters. I delivered the a.m. messages three times each since $\mathrm{HBC}$ is currently running three am services at 8:00, 9:30 and 11:00.

I arranged the material as follows. I introduced the series in the Sunday a.m. service on January 13 with the message "Carried All the Way." Before speaking, I had S1 $1^{31}$ distributed and gave the congregation about ten minutes to complete it. The emphasis in M1 was upon how, since God declares to carry us all the way in Isaiah 46:3-4 "from the womb to old age" and by implication death, we who claim to know this God, should do the same thing, and imitate Him by upholding the dignity of human life as created and carried by God from life's beginning to its end. I concluded this message with a short video by Focus on the Family entitled "Life is Sacred" (2002), which beautifully illustrated all that I had emphasized in the message.

I delivered M2 on Sunday, January 13 at the p.m. service. It dealt more specifically with issues at the beginning of life. It was entitled "Making Babies in the (Not too Distant) Future; Promise and Peril in Reproductive Technology." Some of the young adults in my college class I teach at HBC worked on a skit, "Blindsided by Science," which provided the background for this discussion. After this, I actually unpacked some of the key issues the drama raised such as the potential of our technology for good and evil in general, reproductive technology, sex selection, and Pre-implantation Genetic Diagnosis (PGD) and eugenics. 
My purpose was to identify these issues and explain how they really are important bioethical questions for believers who hold to the sanctity of life ethic. I tried to drive home the major point as to how this doctrine is the guiding principle in our bioethics and gave a practical application by actually going to a live website of a fertility clinic during the message to, in a sense, walk the congregation through the process of evaluating such a site using the sanctity of life ethic as the evaluative filter. I applied this guiding principle to give a practical demonstration of how to sift through the procedures and promises that these clinics use and make. The couple in the skit were blindsided with life and death decisions they had to make about embryos generated for them in the lab. I was hoping this demonstration could serve as a means for precluding that in the lives of my fellow HBC members.

I ended with a brief discussion of how PGD can easily lead us to eugenics again. I then showed excerpts from a testimony by Nick Vujicic entitled, Life Without Limbs (2003). Nick explains how he was born with no arms and no legs, and how God is now using him, not despite his disability, but because of it, to reach places no "able" bodied person could ever have access to for preaching the gospel of Christ. I used Nick's testimony as an illustration of Exodus 4:11 where God makes the startling claim to have "made the mute, the deaf, the seeing [and] the blind." It seems that God is telling Moses that his handicaps are not God's hindrances; a sound biblical principle to guide us in making decisions about PGD and steer us away from the eugenics mentality.

The second and last weekend, January 20, I delivered M3, "Being the Church in the Culture of Death" for the am service. In M3 my purpose was to give an overview of 
the issue of doctor-assisted-suicide, explain why advocates want it, and then provided legal, medical and social arguments against it. I concluded the arguments segment with a brief video I had first seen in one of my classes at Trinity, and found later on You Tube. It is entitled "Anti- Assisted Suicide" and reiterated some of the main questions I had highlighted and ended with the poignant question, "Assisted suicide; with so many unanswered questions, can it really be the right answer?" I then briefly addressed the matter of our attitudes toward the dying from the biblical narratives of Job's friends and Jesus in the Garden of Gethsemane. My purpose was to drive home the point that we must combat the euthanasia mentality by confronting the notion that people are burdens. We must say "you are not a burden. You have a burden, and I am here to bear it with you" and so "fulfill the law of Christ" (Gal 6:2).

M4, delivered January 20 in the p.m. service, was entitled, "Biblical and Medical Guidelines for End of Life Decisions." This one presented me with what, I think, was my most daunting task; to try to articulate some specific, and very practical, guidelines that people could actually use in making end-of life decisions. These practical matters had to do with advance directives, palliative care, and allowing to die by the foregoing of treatments. I began M4 with one of my favorite scenes from Shakespeare's plays; Hamlet's "to be or not to be" soliloquy. I actually showed this scene from the film Hamlet starring Mel Gibson (2004). After the clip, I contrasted the uncertainty and terror of death, the "undiscovered country," that gripped Hamlet, with the utter confidence and welcoming of death as a departure to be with Christ of the apostle Paul as seen in Philippians 1:20-26. I explained how Hamlet's cowardice was his reason for not departing to the other side by his 
own hand, to escape the "thousand shocks that flesh is heir to," and then how Paul's selfless passion for service kept him living on, in the suffering, though departing would be "far better," in order to continue his ministry. I then shared the gospel with the audience through this contrast.

After speaking certainties promised by the Christian worldview, I then proceeded to say that although the believer is confident about what happens after we die, this does not necessarily make dying itself, particularly the dying process, any easier for the believer than the unbeliever. I discussed God's power and sovereignty over life and death, the need to prepare for our dying with advance directives, palliative care and the corollary issue of terminal sedation, then the issue of "pulling the plug." I ended by referring to Jesus' passion and how in His dying, He identified with us in the dying process, and how this can give us comfort of God's presence even as we face our own dying and death. The night concluded with a distribution of $\mathrm{S} 2$. $^{32}$

The immediate verbal feedback on these messages was very positive. Numerous people came up to me and told me how they helped them to put things into perspective, make up their minds about issues they had questions about, and even change their minds to uphold a commitment to the sanctity of human life. It was also encouraging to hear some people tell me that the material on death and dying actually helped them overcome some of the nagging guilt they had felt over ending treatments of loved ones in the past. One elderly lady had come to me in tears to deal with the guilt she had carried for ten years since her mother's death. Several nurses told me that they found the material refreshing and 
accurate. A physician friend said that I "hit home runs" every time. Even in subsequent weeks, I received e-mails and people stopped me in the halls at church to tell me that I had made what they thought were very difficult subjects understandable, practical and above all biblical.

But aside from all this immediate feedback, which encouraged me that I had met some of the major project goals, I had yet to analyze the data of S1 and S2. I will share results from these in chapter four. 


\section{CHAPTER 4 \\ PROJECT EVALUATION}

I had the members of HBC evaluate both methodologies I employed in my field work. This involved a focus group with attendees of the LTE, and a surveying of congregants in attendance for the four-part sermon series; especially the first and last sermons.

\section{Evaluation of the Life Training Elective}

I conducted a focus group on the last day to provide a means for evaluation. 33

Eighteen attended that last session. As I said above, each week was, in a sense, a focus group in which we were constantly exploring what bioethical education in the local church setting might look like; at least up until week seven when our focus shifted to specific issues. I designed the focus group, however, for feedback on this issue. The attendees were cooperative and gave me some beneficial response during this time. I will provide information from this group under each of the questions I asked during our time together.

Question 1 was, "Why would you choose to study bioethics in the setting of the local church? Do you think it is important for a local church to have such educational opportunities; how frequently?" The basic answer was that they knew that the class in the local church would be based on the Christian worldview and that they could pretty much trust the teacher whom Pastor Kroll allowed to conduct it. They have enough outside

${ }^{33}$ See Appendix 2 for the Focus Group questionnaire. 
influence from the world, and this thinking can creep into theirs without their even knowing it. According to one attendee, "We are bombarded and thus influenced by the world's views. Sometimes we are influenced without even realizing it." By focusing on the biblical worldview, we were able to see the worldly ethic in contrast. Another commented as to why the church is the place for this reflection to occur because, "I would know going into the class that the teacher's views on theology would be in line with mine. With that basis I would have greater trust in what the teacher was telling me."

They also felt that it is very important for the church to have educational opportunities on a regular basis, but did not necessarily agree on what "a regular basis" meant. Some said that the best way would be perhaps two addresses per year to the whole congregation (thus from the pulpit). But some questioned as to whether the pulpit and the am service was appropriate for this kind of address. Most maintained that the elective should continue. One was assertive that bioethical discussion is critical to discipleship, stating that, "understanding the ramifications of bioethical advancement is crucial in decision-making within the Christian Worldview. Making decisions . . that please God is what discipleship is all about." This one also tied bioethics into the discipleship ministry of the church.

Question 2 asked, "How has this series enhanced your understanding of bioethics as a Christian? Please explain and be as specific as possible." One attendee sated that it helped to "open my eyes to the bioethical issues that surround us. It helped me see that I need to look deeper than the surface when issues like embryonic stem cell research or in-vitro fertilization come up." Another claimed that "the scientific part helped me to understand bioethics as a Christian." But in response to this, one stated that we 
need to stick more to Scripture, not science. Most agreed with the statement, "the metanarrative idea helped me not only with bioethical issues, but also everyday matters of instructing my children." Adding to this, another said, to my great satisfaction, "This class helped me see that the Gospel is not an end in itself. It affects the whole of life; there is a life to be lived in accordance with the Gospel." This, of course, was one of the main goals of the project. Another stated, "It helps me filter the contemporary news I hear that I did not know how to respond to before" and that it "helped me to talk to my teen-aged girls about these issues." This one continued, "It was the topic of conversation almost every Wednesday night on the ride home from church!" Another claimed, "it made me realize how subtly the world's views creep in," and another that it "provided me with insights to talk intelligently to people who are mostly secular at my place of work about current issues." This same person saw the "apologetics value" of a Christian bioethics and how the information could be used to challenge secular colleagues at work. Of great significance was the comment by our resident ER physician who told me, "I did not learn much at all about bioethics in my medical training, and what I did have, was secular. This class helps me, because it gives me the ethical framework for thinking biblically and ethically about my practice. Often I have paused to think about the ethics of the decisions I am making in the ER as a result of this class." He said he looks forward to the class because of these elements.

In Question 3 I asked the focus group, "What interests were not addressed or needs not met that you would like to see discussed in the future, either in this elective, or from the pulpit to the entire congregation; why?" Overall, the attitude was positive, even with our digression from the syllabus, that the class addressed relevant issues. One thought that there should be more "development from the Scripture of a solid biblical and bioethical 
stand." Another said that what was lacking was "for the congregation to hear this (bioethics) from the pulpit more often" because, "not everyone is willing to take a semester class, but there are issues that we all need to be aware of and the pulpit may be the only place to get the word out to the entire congregation." A great suggestion was that there should be "materials for teens and adults developed that reflect our perspective on what we believe." One thought we could use more "real life examples to show how our position works in a very practical sense," and another wanted to see more specific, "weekly objectives," outlining what we will talk about each week. One became very specific regarding issues and suggested that we discuss, "dealing with aging parents facing end of life issues, and disagreements with parents over end of life wishes."

Question 4 stated, "We have met and discussed critical issues for the last few weeks as a group. What is the importance of a group/community dynamic within a local church for working through bioethics? How can HBC better provide learning opportunities in the future?" Most saw the value in the group dynamic, although one pointed out, "It is good to study this as a group. However, I felt that sometimes a few individuals (other than the instructor) talked far too much. I wanted to hear more from the instructor." (This attendee did not say this during the focus group, but sent me this comment in a later e-mail). Otherwise, the nearly unanimous consensus was that, there is "strength and wisdom in numbers" and a "broader perspective" as everyone shares from his or her "own experience." One pointed out how, "I thought I had my mind made up on certain issues, and then someone would share a whole new angle that actually made me rethink my own position." This is especially significant given the purpose of deliberation in the 4-D process. One stated that they liked how it saw the "church working as the church" as "a group rather than individuals" 
which, of course highlighted the project's goal which envisioned the people of God gathered around the word of God as the basis of bioethical discernment as a community.

As for the future, the group generally concluded that what $\mathrm{HBC}$ was doing with the elective and occasional pulpit addresses was adequate, but also said "we should advertise by word of mouth to get more people involved" with the elective. Another suggested taping the sessions to DVD and making them available through the church library. Most agreed that HBC is "providing more opportunities than other churches [they] had been a part of before." The issue is stirring up interest among people to want to attend the classes. One observed that really it is only through "crisis" that people are going to become interested in these issues; i.e. only as they experienced these matters in real life, and came to the place where they were seeking for answers.

Question 5 asked the group, “ How can HBC (we) encourage bioethical matters, so much a part of our daily lives as we have seen, to arise naturally in the life of the congregation? For example: Should HBC offer counseling on bioethical matters? Should it address bioethical issues in its New Connections class; to what extent and how? Do you have any other suggestions?" The group agreed, for the most part, that HBCs New Connections should address, to some extent, the matter of bioethics and where the church stood on basic issues. It would be helpful to address this then, and inform new members that we have classes for this that they can attend. They also made suggestions like having a column in the monthly news letter, the Heritage Herald, which goes out to all members, and providing books in the bookstore on bioethical issues, as well as having a printed list of websites that deal with bioethics from a Christian perspective. There was also the suggestion that the church could offer a weekend of workshops where people could learn about preparing 
advance directives, taking care of aging and elderly parents, and other such matters. They thought these would generate more interest among the congregation at large. They also like the idea of counseling, but brought up how this would require real competence on the part of those who would do the counseling. And there was the suggestion to address these issues more regularly from the pulpit so that they would be put before the congregation more frequently.

Finally, Question 6 dealt with, "How might our Health Care Professionals (doctors, physician assistants, nurses and medical students) become more involved in the bioethical education of the congregation?" According to one, "I think many people are just unaware of the issues that arise every day, if a healthcare professional spoke out on what they see and experience on the job, it might bring an awareness that no one else could express." Others thought that HCPs could give more of the technical expertise and scientific background to the issues, but that they do not necessarily know the ethical implications of the issues. Even the ER physician who attended admitted this, and said that he depended on the class a lot to get his ethical perspective from the standpoint of his Christian worldview and how it applied to his practice. One RN in attendance concurred, and said that she needs the class before she could teach it herself.

G3a and G4 was especially developed with this focus group in mind. They state in turn, "To educate the congregation about and improve their understanding of relevant bioethical issues and biblical responses to them by, providing an educational opportunity for in-depth discussion about bioethical issues" and, "To lead selected individuals from the congregation in an exploration as to how the church can further encourage bioethical understanding among its members in accordance with the doctrine and ministry goals of the 
church." I feel that based on the discussion that ensued in that last meeting, the highlights of which I summarized above, we successfully achieved these goals.

\section{Evaluation of the Sermon Series}

For the sake of time, I will present my findings from a random sampling of about 200 congregants who took S1 on January 13, 2008 in the am service (although I received about 450 back), the Health Care Professionals (HCPs) who took S1, then all those who took S1 and S2 and heard all the messages. I will also make some relevant comparisons between those who took both surveys and heard all four sermons and those who did not take both surveys or hear all four sermons or a combination of both. I will not go into a lot of detail with these comparisons, but some differences, which I will discuss below, are noteworthy. Instructions on these surveys were that only adults 18 years and older could take them.

In S1 I separated the results between Health Care Professionals (hence HCPS - to include those retired from the field, presently involved, or studying for it in college) and non-medical personnel (hence NMP). The former group included 49 surveyed, and the latter 200 (randomly selected from 447 surveyed).

With regard to "bioethics" itself, there was a very strong opinion, 90\%, in S1 among NMP that "bioethics should regularly be addressed by the church," with only $1 \%$ saying that it is "too academic," $0 \%$ saying it is "too political" and $1.5 \%$ saying it is "unrelated to church doctrine." So, overall, there seems to have been a feeling, among HBC members, that there is an important place for bioethical education in the local church. An interesting point, however, is that there were $10 \%$ who agreed that bioethics is "too 
complicated for the average person to understand." Of the HCPs surveyed on this point, $92 \%$ said that the church should regularly address bioethics, and $12 \%$ that it is "too complicated for the average person to understand."

About 175 people took $S 2$, and 88 of these $(50 \%)$ indicated that they had taken both surveys and heard all four messages. Of this latter group, $0 \%$ indicated that the sermon series had "turned them off from bioethics," "done nothing to improve my understanding of bioethical issues," or convinced them that the church has "no business" addressing bioethics. Positively, $82 \%$ indicated that they had received a "greater understanding" of the term "bioethics," and $84 \%$ that they had become "more aware of issues that are bioethical in nature." This shows strongly that the sermon series met G1b and G1c about the understanding of the terminology and identifying bioethical issues respectively. $89 \%$ indicated that the messages had "given me a greater awareness of bioethics in our culture," which accords with G1a, illustrating the urgency for bioethical education, and 83\% said they saw more how "the Bible and theology applies to bioethical issues," meeting G2a and G3b about seeing how their doctrinal tradition weighs in on the issues. $75 \%$ said that all four messages had given them a "greater understanding of the sanctify of human life as a guiding principle in bioethical decision-making." I think that $\mathrm{HBC}$ had a strong view of the sanctity of human life going into the sermon series as $98.5 \%$ indicated in S1 that they believed human beings are "created by God in His image" and $86 \%$ that this meant that humans should be "treated with dignity and respect" unconditionally. Although this is about a $10 \%$ drop, showing that the former belief does not necessarily translate into ethical behavior for some. 
The series did not necessarily stimulate as much desire to do personal research as I would like to have seen. While 67\% (well over half) indicated that their desire had been "increased for more bioethical education and discussion," only $26 \%$ said they had been "stimulated to do more bioethical research on their own." Thus the conclusion that more education is needed in the church, does not necessarily translate to personal education and research. They are dependent upon the church to provide this research and education for them. 58\% said that the sermons had "stimulated discussion" in their family, and $66 \%$ said they had become more committed to educating their "children and grandchildren about bioethics and the sanctity of life." As for this point, again, congregants feel the need and want to educate their families, but are looking to the church to provide the research and information to do so. Finally, $73 \%$ said the sermons "heightened my awareness" to bioethical issues in news and other media. Overall, it appears the sermon series met all the goals (particularly G1a-c, G2a-b and G3b) germane to that particular mode of education in the church.

When asked about the modes in which bioethical education should occur in the local church, 53\% indicated that it should occur "more frequently from the pulpit," so there was still nearly half who, having heard all four messages, did not necessarily think that this was the preferred medium for such education. $75 \%$ said that bioethical education "should occur regularly as a life training elective" which I have been doing now for a number of years. Only $26 \%$ thought that a series in their ABF would be appropriate. $61 \%$ said they would like to see books in the library and bookstore addressing bioethics. There was an interesting shift in that of those who took S1 only 53\% of NMP said they would like to see these resources in the library and bookstore, an $8 \%$ increase after the sermons. Interestingly, 
on this point, in S1 only $45 \%$ of HCPs thought this necessary. 50\% would like to see an "MTW" (an annual Ministry Training Workshop the church holds every fall to help equip the congregation to do ministry to each other) devoted to bioethical issues. Yet $85 \%$ indicated, and many with enthusiastic comments in the margin, that they would like to see $\mathrm{HBC}$ provide "bioethical counseling services for people facing infertility, end-of -life dilemmas, etc."

Only $2.3 \%$ of those who took both surveys and heard all four messages said that their view on when human life begins had changed, and only 5\% that their view on the sanctity of human life had changed. This is actually a good thing when you consider that of NMP who took S1, 96\% said that human life begins at "fertilization," and 90\% that human life should be legally protected from that moment. A corollary to this is that $88 \%$ indicated in S1 that human embryos are "persons equally created in the image of God as any born person" and 91\% that human embryos are worthy of respect and legal protection. In S1 only 7\% agreed that human embryos are "potential human beings, but not fully human." I should also like to mention that of the HCPs who took S1, 96\% agreed that human life begins at fertilization, and $92 \%$ that it should be legally protected from that moment. $92 \%$ of HCPs considered human embryos to be "persons equally created by God as any born person," and 94\% that human embryos are "worthy of our respect and legal protection." A refreshing point was that $100 \%$ of the HCPs surveyed in S1 agreed that humans are "created by God in His image!"

As to specific issues addressed, $30 \%$ of those who took both surveys and heard all four sermons said that their views had actually "changed" on assisted reproduction issues. In S1 32\% indicated that in-vitro fertilization might cause or result in the death of a human embryo. I did not provide a mechanism to see if this particular view had changed, but I 
addressed it in the first pm service in the sermon "Making Babies in the Future." I did have a few come up to me afterwards and tell my personally that they "never knew" how IVF could result in embryo death. 58\% of those surveyed said that while their views had not changed, they did receive "information that helped them explain/defend their view more adequately."

Only 8\% said that their views had "changed" on assisted suicide. This was probably good, because in S1 only 4\% agreed that assisted suicide should be legally available for people who have a "terminal illness and are in much pain" and only $2 \%$ that it should be legal for those who had "lost the will to live due to terminal illness." Although these numbers are small, I am glad to report that after the second pm service, a man came and told me that he was leaning in the direction of thinking assisted suicide should be legal for certain hard cases, but that he had never considered the social implications for such a policy, which I addressed in the am service on Sunday the $20^{\text {th }}$. He said, "so that changed my mind." Of the HCPs only $2 \%$ for both of the questions in S1 agreed with assisted suicide. $52 \%$ of those who took S2 and heard all four sermons said that they had received information that helped them to explain/defend their views more adequately on doctor assisted suicide, and 59\% on "when it is or is not right to withhold or withdraw treatments from the terminally ill" which was one of the points I emphasized in the last sermon entitled "Biblical and Medical Guidelines for End of life Decisions.”

When asked about educational resources in the local church in S1, 94\% of NMP surveyed said they believed HBC should "provide or continue to provide educational opportunities on bioethical issues." $38 \%$ said they read the Community Action Committees (CACs) weekly updates in the Praise Gram (the weekly p.m. service program). Only $16 \%$ said they had acted on this and called, written or e-mailed their congressperson (the 
communiqué always provides specific action points for responding to the political and bioethical briefs in it). $34 \%$ said they read the CAC's monthly column in the Heritage Herald (the monthly news letter mailed to the homes of all HBC members), and only $13 \%$ said they acted on this information. But $75 \%$ said that HBC should continue to have these updates and columns! $12 \%$ indicated that they pick up literature from the CAC center (a location in our church where current information and literature is regularly available on social, moral and political issues). Over half (56\%) said that this information should continue to be available. $45 \%$ of those surveyed in S1 indicated that their decision to attend or remain at HBC was based on its "stance on certain ethical issues." 63\% said that the annual Sanctity of Human Life Sunday services should continue to be a part of HBC. 26\% indicated that they had participated in a Life Chain (a silent and prayerful protest to abortion in which the church annually participates) and $27 \%$ that they would like to see the CAC provide more opportunities for "involvement in social/moral issues." $53 \%$ said that they would like to see resources in the library and bookstore on social/moral issues, and to see HBCs HCPs take a more active role in educating the congregation in bioethical issues. $30 \%$ said they would like to see bioethical issues addressed in New Connections (HCBs new member class).

Although the statistics were similar with the HCPs as compared to the NMP surveyed, there were some interesting differences. 97\% said that HBC should provide such resources compared to the $94 \%$ of the NMP surveyed. Another interesting difference was that while 53\% of the non-medical people said they would like to see the HCPs more involved in the church's bioethical education, $69 \%$ of the HCPs apparently would like to take this role; a difference of $16 \%$ ! 
There seems to have been some notable differences in whether those surveyed had heard all four lessons or not, or whether they had participated in both surveys or not. $0 \%$ of those who took both surveys and attended most sermons said that the messages turned them off from bioethics, did nothing to improve their understanding of bioethics, and convinced them that the church should not teach bioethics. Of those who attended fewer sermons and only took S2, however, 5\% said that it had turned them off from bioethics and $2 \%$ that it had done nothing to improve their understanding. Those who had not attended most sermons had consistently lower percentages in indicating that the sermons had impacted them in any positive sense.

Another notable variation was how of those who had not attended most sermons and only did the last survey, $11 \%$ said their views had changed on assisted reproduction issues, and of those who did both surveys but not all four lessons $8.3 \%$ indicated a change on this issues. While $30 \%$ of those who attended all four sermons and taken both surveys said their view had changed on this. It is probable that the majority of the former two groups did not attend the pm service on the first Sunday in which I specifically addressed these issues. This may indicate that even a 30 minute message can make a difference in people's thinking on vital bioethical issues! The other areas of change indicated were pretty much the same for all three groups, but there was a significant difference in that of those who did not attend all four lessons but took both surveys, $42 \%$ as compared to $23 \%$ for those who did not attend most lessons and took only S2 and 25\% of those who had attended all four sermons and taken both surveys, indicated their view had changed on when to discontinue treatments for the terminally ill. 
A notable difference also occurred between these three groups on the matter of the sermons giving them "more information to explain/defend their views more adequately. These statistics again indicate the high possibility that those who did not attend all four sermons missed the first pm service when I addressed the matter of assisted reproduction. $27 \%$ of those who had missed most sermons and taken only S2 said they felt this way, while $42 \%$ who took both surveys but did not attend all four lessons, and $58 \%$ of those who attended all sermons and did both surveys said that this was the case for them.

There were some interesting and potentially significant differences between NMP and the HCPs on certain questions in S1. Regarding whether certain technologies "cause (or may result in) the death of a human embryo," across the board HCPs saw more potential danger for the human embryo in birth control/contraception (51\% of HCPs to $39 \%$ of NMP), embryonic stem cell research (80\% HCPs to 70\% NMP), certain methods of abortion (98\% of HCPs to $86 \%$ NMP), In-vitro fertilization (57\% HCPs to $32 \%$ NMP) and therapeutic cloning (69\% HCPs to 39\% NMP). Perhaps these significant differences, especially with the last two (25\% and 30\% respectively!), indicate that the HCPs should indeed take a more active role in bioethical education in the church. These professionals know the science better, and thus the potential dangers each of these technologies have toward the human embryo. Further differences are that about 5\% less HCPs are confident that "God can be glorified" even if couples freeze their left-over embryos from fertility treatments, and 5\% less HCPs agree that freezing human embryos is "morally acceptable."

Another area of difference, possibly indicating that our HCPs should be involved more in the educational process in our church, is that a full $12 \%$ more of HCPs agree that "death should be accepted as an inevitable part of human experience," and 6\% 
more HCPs would agree that "allowing a dying person to die, and letting nature take its course" is moral. 94\% HCPs versus 75\% NMP say that "the dying should be kept comfortable even if they cannot be cured" and 9\% more of HCPs agree that "doctor assisted suicide is immoral and should never be legal." $11 \%$ more HCPs agree that "all people should have some kind of advance directive.” In light of some of these discrepancies, I would say that, although a greater percentage of HCPs believe that they should have a hand in instructing the congregation on bioethical issues (69\% HCPs to 53\% NMP) perhaps HBC should arrange for its HCPs to take a more active role in this education. Another indicator for this need is that while there is a close connection between HCPs and NMP regarding the matter of humans being created in God's image (HCPs 100\% to NMP 99\%) there is a disconnect when it comes to this theological position impacting medical ethics. While $96 \%$ of HCPs agree that humans created in God's image "should be treated with dignity and respect" unconditionally, $86 \%$ of NMP hold this ethical position. 


\section{CHAPTER 5}

\section{LESSONS LEARNED AND RECOMMENDATIONS FOR FUTURE MINISTRY}

I should like to share specific ways that God has taught me as I have engaged and reflected on this project and its outcomes. He has taught me in ways I did not expect, and for which I am grateful. I can also see how these particular lessons can serve as the basis for future bioethical ministry at Heritage Baptist Church.

\section{Lessons from the Life-Training Elective}

As I embarked on this inquiry into how a local church can educate its congregants in bioethics, I had no idea where, first, the research would take me, but also how involved it could be just with a few goals articulated at the outset. My greatest surprise was that, as I got into my research, I would find out how the concepts of narrative and community would be such a major emphasis in the literature. This, in a way, changed my course, and really started coloring the way I was not only teaching bioethics, but even thinking about it. As my project clearly shows, I became enamored with the work of Allen Verhey, especially, and the more I read and reflected on Verhey's propositions, the more I began thinking to myself that this would be a good way to organize the project; to actually put into practice the activities he spoke of; discourse, deliberation and discernment, in a community setting. I envisioned, as he did, God's people gathered around God's word using the story of Scripture to discern what we ought to do, and what we ought to leave undone. 
I had been teaching worldview for a number of years at Liberty University, and when I read Verhey's depiction of the sweeping storyline of Scripture from creation to consummation centered in Christ, it resonated with me that this was the biblical worldview. I saw clear connections between what Sire and Carson were saying about the biblical metanarrative and worldview with what Verhey was saying, and the more I read other authors about bioethics from a Christian perspective, like Eyer and Wheeler, and even the Lausanne Committee's Occasional Paper, I concluded that this was how to go about this task. Although I still maintained the overall desire to explore bioethical education in a local church setting, this framework gave me a whole new perspective. I really have come to believe that casting bioethics in such a framework would make it accessible to the non-academics in the church, which is what I had in my mind to do even before stating my doctoral program at Trinity, and demonstrate its relevance to God's people, because the biblical story informed it. So I wanted to talk about bioethics, much like these authors did, in the context of the biblical story. Although I set out with this specific goal in mind, I feel now that I did not achieve it the way I would have liked to.

I found, mainly, that God's people (particularly my LTE group) were not where I was in this. I had, of course, been reading thousands of pages of material, been immersing myself in this new thought world, and becoming increasingly excited about this prospect. They, of course, had not, and if I was to see this overall dream realized, I would have to somehow give them what I had, and this was pretty near impossible. How could I express all that I had been learning? 
I thought I might be able to guide people into a real experience with community (each other) using the biblical narrative as the basis for bioethical discernment. I thought this idea would really catch on! I now think I was somewhat over ambitious. But I am not discouraged, nor am I daunted in achieving this, even after I am through with this project. This "failure" has actually led me to one of greatest lessons learned. Change, and especially a paradigm shift in ethical procedure, takes time. What I have been learning cannot be conveyed in a couple of lessons, as I designed for the LTE schedule. I had planned to discuss bioethics and the challenge facing the church on week one, and then ready my group to do bioethics in the next two lessons, equipping them to discuss "stories" of procreation, health, sickness, medicine, dying and death. As it turned out, we got off course early because I was, and still am, committed to allowing more dialogue than me just standing and teaching, especially in this elective setting.

Another thing that I did not really do with regard to my goals was to wed the narrative idea with the doctrinal statement. I had high ambitions for this, and I was personally enriched while reflecting and writing on these matters at the end of chapter two; especially dealing with the ordinances (sacraments) of baptism and communion. I couldn't wait to get my group into this discussion! Yet, without a real commitment to the biblical narrative in the first place, and seeing its overall value for doing bioethics, the connection between this and the doctrinal statement and ministry of the church cannot be identified and articulated.

As I mentioned in chapter three, by week seven of the LTE we were discussing more foundational questions about embryonic humans and when life really begins, we were 
off task from my goals, but, in a sense I let the group set the agenda from here on out. I listened to their questions and put together lessons to specifically address their concerns. I feel that from this standpoint that the LTE was a success, and the focus group evaluation indicates this. Further, while I have not yet seen this vision for communal bioethical discernment come to fruition, there can be no doubt that the LTE achieved specific goals established for this project.

One of the challenges, of course, as with any series presented in a group setting such as this, was that there were new people each week. The reason this was particularly challenging was that I was seeking to frame this entire project on the basis of the biblical narrative. Without the same exact audience each week, and new ones coming all the time, it was necessary to review previous material to get people up to speed as to how we are doing bioethics. If I could not convey this in two weeks to the regular group, I certainly was not going to be able to do it in a five minute introduction to get people "caught up" before proceeding with the lesson. Not only can this repetition of such basic ideas be tedious and even boring to those who are regularly attending, but there is no way to do justice to it and really school people in the process. These lessons were not mutually exclusive in the sense that no matter what bioethical issue we would be discussing required the framework of the metanarrative to proceed through the process of discernment and decision. Further, it required a community immersed in the biblical narrative to do bioethics in this way.

I am committed to using Verhey's concept of moral discernment by way of remembrance as an effective model for bioethical education in the local church and still want to explore how I can really apply this at HBC. While the students definitely showed interest 
and intrigue with the concept, some still had a difficult time actually making application of the issues to the Story as outlined; or to, as Verhey presents it, plot the big story and then plot our stories so that they align with that story. They could clearly see some of the connections but it was not always obvious.

I still feel that this method is valuable because it is using familiar ground, a church's theological tradition, as the basis and context for moral discernment. I am new at this, of course, and see a lot of wrinkles that still need to be worked out, but for now I would say that this project's goals, particularly insofar as they entail using such a specific framework and process, cannot be achieved without some kind of antecedent education.

Yet, as the focus group results reveal all was not lost. The group definitely benefited from the material and the weeks we spent together, even though we returned to a more, what I will call "traditional," mode of bioethical education; bringing up a social issue, trying to understand it, and the science surrounding it, and then applying relevant biblical references to resolve the issue in a way that is consistent with our Christian convictions. As the comments in the focus group indicate, they felt that we were biblical (despite the one attendee who thought we could be more so).

I am not sure exactly how to implement this educational paradigm, and, as I already indicated, I will not give it up, but for now, I will need to be more "traditional." I see that this is what we are doing already in this spring elective, which we are having, by the way, due to demand that we continue the elective. We have more people attending now, and our conversations have already been enriching. I have discussed the biblical narrative, but it is difficult to stay with it due to the way people want to discuss the issues. When they ask 
"what's the Bible say?" they are, for the most part, looking for proof texts and single references dealing with the matter, not for how our stories can be aligned with the big story. Nevertheless, there are signs of encouragement. People are beginning to refer to the "story" without prompting in addressing the issues under discussion.

Out of the LTE some valuable suggestions and lessons have emerged. Truly, there is a hunger for bioethical education at $\mathrm{HBC}$, and there is, overall, a perspective that these issues should be addressed from the pulpit at times, but also that there should always be an elective offered to the church. They have suggested that we should record the sessions and make them available in the library, and they have suggested that we develop workshops that address practical issues like preparing advance directives and caring for aging parents. This is feasible, and I will be exploring how we might develop such workshops for a Saturday mini-conference next spring.

One thing I learned, and that emerged as a key concept in my thinking is that when we are dealing with bioethical issues, unless we know how the science works, we cannot begin to understand how the Scripture applies. That is, we cannot begin our bioethics until we understand the biotechnology. We cannot, for example, really make moral judgments about in-vitro fertilization or cloning until we know something of the science in these procedures. Only when we discover that IVF requires the generation of numerous embryos which will not be implanted, can we begin the bioethical reflection on what to do with them, or whether to generate them in the first place.

Another principle of importance that has emerged in my thinking is the idea that good ethics, and bioethics, does not necessarily mean finding answers, but can be 
equally valuable when it simply asks good questions; the kind of questions that cause us to pause, and even leave something undone, because there are too many variables that remain unanswered. I keep conveying this to the elective group, and even touched on this in my sermon series.

But the flip side of this is that the questions that surface when we really start reflecting on any given issue can result in a sense of hopelessness that there are any ultimate answers. Are there any "bright lines" in bioethics? "Does everything have to be so gray?" asked one lady taking the elective at the end of one of the sessions. The Mathematician/Logician actually said to me, tongue-in-cheek, one evening after a session "I'm glad you're the one doing bioethics, I'll take the certainty of my mathematics any day." Although this generated laughter, it was nervous laughter, because there is some serious truth to it. Some seriously did not relish the dialogical nature of the elective, and really only wanted to hear from an "expert," no matter how much I tried to push the Colossians 3:16 concept of "teaching and admonishing one another in all wisdom" rather than relying on an expert. I think they looked to me a little too much for the "answers" rather than really enjoy the dialogue with their fellow saints. I think that if I can "sell" the concept of moral discernment as a community on the basis of the biblical metanarrative, this will change, I just have to think of a creative way to do so.

One final lesson that I have learned is something that I have reiterated several times throughout this project, and really stressed in the LTE. I really think that this is indispensable. With an emphasis on bioethics from a Christian perspective we have to focus as much on what some of our congregants have already done as we do on helping them 
decide what to do. The former group of people needs to be shown how redemption can come out of their desperate situations. I am seeing more of this now than before. I am seeing that as we create an atmosphere of safety, there will come more confidence and confession. We are continuing to grow in this area. We have had confessions of past abortions, or temptations to abort a pregnancy, and one shared about how she thought she "pulled the plug" on her dying husband pre-maturely, and is still carrying guilt about that. While there is no doubt that pastors and Christian counselors need to guide people through the ethical mazes and minefields of biotechnologies, equal effort needs to go into helping people through the guilt of having made decisions that fall short of God's moral will that will inevitably emerge as any given church places emphasis on the sanctity of human life and bioethical issues.

\section{Lessons from the Sermon Series}

By nature, the preaching was much more direct and to the point, and there was no time for dialogue (although some had suggested in their surveys that they would have liked this; perhaps a Q and A following the message). Nevertheless, the overall feedback from the four sessions was very positive, and the congregation generally saw the experience as informative and useful in their lives and families, as we saw above.

I think the most troubling thing for me with the preaching was, as I said before, how to squeeze so much into thirty five minutes or less. By the last message, however, I had perfected a structure for getting it done in this amount of time. I had to stay on task, and not digress, in order to come to all my points and bring home the conclusion. I had no time for veering from the path, but over-all this was a good discipline. 
I also had the challenge of making difficult concepts intelligible to an audience not familiar with bioethics. I think this was successful. One of the greatest things about the sermon series was the immediate verbal feedback that came. One man, for example, told me that his wife, who usually struggles with science and technical ideas, told him that she understood what I was saying. Another MD friend of mine told me that his daughter who has a distaste for scientific "stuff" generally actually benefited greatly from the material. She even called my home and thanked me personally for my ministry in this area. I even had a couple of the teens say they really enjoyed it, and that it kept their interest because they could understand it. This is always good for a preacher.

Yet, I felt that I did not, once again, achieve all the goals I hoped to, especially my goals $2 \mathrm{a}$ and $3 \mathrm{~b}$ which address the matter of showing how the doctrinal statement can be connected to and consistent with bioethical issues. I preached the series long after the LTE was over, and the reason I mention this is that the LTE experience actually showed me that I was definitely not going to be able to develop the "story" as a context for the bioethical reflection we would do during the sermons.

I suppose I could have lifted specific points from the doctrinal statement, but I did not. I did reference the story in the messages at certain times. For example, in the third sermon I spoke of Jesus' Garden experience and how this serves as a model for us to be there and watch and pray with those suffering and sorrowing unto death. In the fourth sermon, I brought up how Jesus' experience of going through the dying process gives us hope that even in our suffering at the end of life, God will not forsake us, but uphold us all the way to the end. I also referenced the fact that Jesus identified with us in our human journey by taking 
on a body as an embryo just like us, and sanctifying every step of the human journey from womb to tomb. With this said, however, I really did not develop the point of the story and our stories, nor did I make specific reference to our doctrinal statement. I felt that time did not permit this kind of development.

\section{Recommendations for Future Ministry at Heritage Baptist Church}

As we saw in chapter four, recommendations from the focus group and data from the surveys surfaced some key information that can serve as the bases for future bioethical education and ministry at HBC.

We know that the congregation of HBC wants to have regular bioethical education, $90 \%$ indicating this in the first survey and $94 \%$ in the second. This should tell the leadership that they need to make specific plans to keep this going. One way to do this is to continue to expand the lessons of sanctity of human life (which 63\% say they want to see continue) to include many more life issues that have a definite impact on human dignity. I will continue to research bioethical issues and see how new biotechnologies impact human dignity and report this to the church. We know that $\mathrm{HBC}$ has a high view of human life, and for most, this translates into an ethic of unconditional respect for all humans. Yet there are some who do not see this connection and we will need to develop ways to close the gap on this disconnect.

We must address the issue of the complexity of bioethics since $10 \%$ see it as too complicated to understand for the average church member, and $12 \%$ of our HCPs think this. Since, as we saw, the congregation largely agrees that the church must address the 
issues, the leadership will have to strategize as to how to overcome the difficulty factor of bioethics education. This might be accomplished by teaching vital lessons with non-complex language that can be understood by the masses. This motivates me more to cultivate an environment where the biblical metanarrative is the major context for moral discernment. This makes bioethics accessible to people regardless of their educational background.

We also saw that, just because HBC members do think that they should receive bioethical education in their church, it is through the church that they are expecting to get it! They do not appear to have a commitment to do their own research. Just over half want to hear bioethical education coming "more frequently from the pulpit," and "to see more resources available in the library and bookstore." $50 \%$ would like to see an MTW devoted to addressing bioethical issues. I have recommended to our bookstore manager/librarian several volumes, to have available to our congregants, and we have begun discussing having a bioethics section. We should soon have in the BioBasics series, and the volume Does God Need our Help? by John Kilner and C. Ben Mitchell. All of these books answer to the need for putting complex bioethical issues in layman terms. Perhaps an MTW with the TV series "House" as the backdrop could be used, but this, of course is far from comedic, except maybe for Dr. House's biting sarcasm. I am willing to work closely with HBC to develop such an MTW in the future should the leadership see fit.

The greatest areas of interest that emerged from the survey regarding future bioethical ministry at $\mathrm{HBC}$ are that the members agree that the church should provide a regular elective opportunity addressing bioethics (75\%), and that HBC somehow make available "counseling services" for people facing bioethical crises (85\%). I want explore 
new ways to get more of the people of God gathered around the word of God as the basis for communal bioethical discernment. I am also willing to work on the matter of providing some kind of counseling services in the future. But this matter is touchy, since, as we discussed in the LTE focus group, there would need to be a certain level of competence to do this kind of counseling. Yet in light of the pressing nature of bioethics in our culture and the church, and the responsibility of the church as the guardians of the very concept of the sanctity of human life, this may need to become a pastoral role in local churches; to have ministers who know the bioethics, know the Bible and how they relate, and keep people informed.

Finally, the survey data seem to indicate that there is an importance in HBC looking into how to utilize their resident HCPs to minister to the congregation regarding bioethical education. HCPs have scientific and medical knowledge that can be of tremendous use to all of us when facing medical decisions, and based on the survey results, it would seem they themselves are willing to be used in this way. We need to explore how better to employ them in this bioethical ministry in the church. Based on my close association with the one ER physician in the LTE, I have learned that HCPs, including physicians, get a small amount of ethical training in their field, and what they do get will probably mostly be secular. If this is the norm, there may be a place for churches to provide bioethical educational opportunities directed toward their HCPs so that they know how to merge their Christian convictions with their practice.

Dr. Jerry Kroll, Senior Pastor of Heritage Baptist Church in Lynchburg, VA is passionate about communicating the relevance of God's word to the everyday lives of believers. He loves God, His word and people, and has structured the ministry of HBC to 
reflect that in so many evident ways. Kroll is also very concerned about bioethical issues in our culture and has addressed them, and provided opportunities to address them, "beyond abortion." Hopefully this report has effectively connected bioethics and the process of Christian moral discernment not only to the educational aspects of the congregation, but also the worship and ministry of $\mathrm{HBC}$ as well. $\mathrm{HBC}$ is, in many ways, a model local church ministry, and by becoming more innovative in how it addresses bioethical issues, it will be even more so. 


\section{APPENDIX 1}

\section{INFORMED CONSENT AGREEMENT \\ FOR HERITAGE BAPTIST CHURCH \\ MEMBERS AND ATTENDEES OF \\ LIFE TRAINING ELECTIVE}

The research in which you have been requested to participate is designed to investigate the perception of our congregation concerning the role of a local church with regard to bioethics and bioethical education. This research is being conducted by Rev. Will Honeycutt as part of his Doctor of Ministry Major Project. In this research, you will be asked to answer some questions concerning your current views and understanding of bioethics and its implications for church ministry. Your responses will be recorded on audio cassette during each session.

By your completion of this form, you are giving informed consent for the use of your responses as recorded in the completion of this research project. Please be assured that any information that you provide will be held in strict confidence. At no time will your name be reported in connection with your responses, or in any materials or publications that may arise out of this research.

Your participation in this process is completely voluntary, and if at any time you feel unable or unwilling to complete it or any part of it, you are free to refrain from comment or withdraw from the project.

I understand the terms as presented and agree to participation in this research. I understand that if I feel unable or unwilling to continue my participation I am free to withdraw.

Name

(Print) (Sign)

Occupation

Date 


\section{APPENDIX 2 \\ INTERVIEW QUESTIONS FOR ELECTIVE ATTENDEES (FOCUS GROUP)}

You have completed HBCs 13-week elective for discussing bioethical issues, please assist me by making critical comments and providing recommendations to improve upon this course to further equip the congregation of HBC to meet these challenges. Thank you.

1. Why would you choose to study bioethics in the setting of the local church? Do you think it is important for a local church to have such educational opportunities; how frequently?

2. How has this series enhanced your understanding of bioethics as a Christian? Please explain and be as specific as possible.

3. What interests were not addressed or needs not met that you would like to see discussed in the future, either in this elective, or from the pulpit to the entire congregation; why?

4. We have met and discussed critical issues for the last few weeks as a group. What is the importance of a group/community dynamic within a local church for working through bioethics? How can HBC better provide learning opportunities in the future?

5. How can HBC (we) encourage bioethical matters, so much a part of our daily lives as we have seen, to arise naturally in the life of the congregation? For example: Should HBC offer counseling on bioethical matters? Should it address bioethical issues in its New Connections class; to what extent and how? Do you have any other suggestions?

6. How might our Health Care Professionals (doctors, physician assistants, nurses and medical students, become more involved in the bioethical education of the congregation? 


\section{APPENDIX 3 \\ INFORMED CONSENT AGREEMENT FOR HERITAGE BAPTIST CHURCH MEMBERS AND ATTENDEES}

The following survey on bioethics is designed for adults only 18 years of age and older.

The doctoral research in which you are about to participate is designed to investigate the perception and understanding of our congregation concerning the role of a local church with regard to bioethics and bioethical education.

By completing this form, you are giving informed consent for the use of your responses in the completion of this research. This information will be kept anonymous and held in strict confidence.

Your participation in this process is completely voluntary, and if at anytime you feel unable or unwilling to complete it or any part of it, you are free to withdraw from the process.

Thank You,

Willie E. Honeycutt, M.Div.

Bioethics Survey Instructions:

Unless otherwise stated, check all that apply. Leaving a space blank will automatically be interpreted as a "disagree" or "no."

In my view "bioethics":

[ ] Is too academic; irrelevant to church life and ministry

[ ] Is too complicated for the average person to understand

[ ] Is too controversial and political; inappropriate for church

[ ] Is unrelated to church doctrine and ministry

[ ] Should regularly be addressed by the church

I believe that human beings:

[ ] Are created by God in His image and likeness

[ ] Should be treated with dignity and respect regardless of their stage of development, physical ability, intelligence or any other factor

[ ] Must obey the moral will of God which is revealed in the Bible 
I believe human life begins (CHECK ONLY ONE): 
[ ] Once fertilization is complete (union of egg and sperm)

[ ] Between fertilization and implantation into the woman's uterus

[ ] Sometime between implantation and live birth

[ ] At birth

[ ] Sometime after birth

[ ] Not sure

I believe human life should be protected by law from deliberate destruction (CHECK ONLY ONE):

[ ] Once fertilization is complete (union of egg and sperm)

[ ] Sometime between fertilization and implantation of the embryo into the woman's uterus

[ ] Sometime between implantation and live birth

[ ] At birth

[ ] Sometime after birth

[ ] Not sure

Which of the following technologies cause (or may result in) the death of a human embryo? (If you have "No Knowledge" on the subject check [NK])

[ ] Birth control/contraception [NK]

[ ] Embryonic Stem Cell Research [NK]

[ ] Certain methods of abortion [NK]

[ ] In Vitro Fertilization [NK]

[ ] Therapeutic Cloning [NK]

I believe human embryos:

[ ] Are expendable research material with little to no moral status

[ ] Should be generated and used to develop stem cells for treating disease

[ ] Are potential human beings, but not fully humans

[ ] Are persons, equally created in the image of God as any born person

[ ] Are worthy of our respect and legal protection, like any born person

With regard to infertility and its treatment I believe:

[ ] God can be glorified through technology that helps infertile couples even if human embryos are frozen and stored

[ ] Freezing embryos from fertility treatments may be morally acceptable, if they are given a later chance to become a fully grown human

[ ] Donating sperm or eggs to assist infertile couples is morally acceptable

[ ] God "opens and closes the womb," so technology to treat infertility is "playing God" and not morally acceptable

With regard to dying and death I believe:

[ ] Death is in the hands of God and we should do nothing to end it ourselves

[ ] Death should be fought against at all costs in every case

[ ] Death should be accepted as an inevitable part of human experience 
[ ] Allowing dying people to die, letting "nature take its course" is moral

[ ] The dying should be kept comfortable even if they cannot be cured

[ ] Someone with terminal illness and in much pain, should have the legal option of Physician-assisted suicide

[ ] Someone who loses the will to live due to terminal illness, should have the legal option of physician-assisted suicide

[ ] Physician-assisted suicide is immoral and should never be legal

[ ] All people should have some kind of advance directive to communicate their wishes about the level of treatment they desire when dying

Education and resources in the local church:

[ ] HBC should (continue to) provide educational opportunities on bioethical issues

[ ] I read the Community Action Committee's weekly updates in the Praise Gram

[ ] I have acted on this information (called, e-mailed, written my congressmen)

[ ] I read the Community Action Committee's monthly column in the Heritage Herald

[ ] I have acted on this information

[ ] HBC should continue having these updates and columns

[ ] I pick up literature from the CAC center (located next to information center)

[ ] HBC should continue to provide current literature and resources at the CAC center

[ ] My decision to attend or remain at $\mathrm{HBC}$ was/is at least partially influenced by what its stance is on certain ethical issues

[ ] The Sanctity of Human Life Sunday services should continue What issue(s) I would like to see addressed

[ ] I have participated in the Life Chain to silently and prayerfully protest abortion

[ ] I would like to see the CAC provide more opportunities for involvement with social moral issues.

[ ] I would like to see HBC provide resources through the library/bookstore that address and instruct on social, moral issues.

[ ] I would like to see HBC's Health Care Professionals (Doctors, Nurses, etc.) educate on bioethical issues since these issues involve medicine.

[ ] I would like to see some basic bioethical issues addressed in New Connections

Demographics

What is your age?

[ ] 18-24 [ ] 25-34 [ ] 35-45 [ ] 46-64 [ ] 65 or over

What is your gender?

[] Male [] Female

What is your marital status?

[ ] Single, never married [] Married [ ] Divorced or separated [ ] Widowed

[] Remarried 
What is your highest level of formal education?

[] Less than high school [] High school graduate [ ] Some college, trade or vocational school [ ] College degree [ ] Post graduate work or degree

What best describes you as a Christian?

[ ] Christian for over 10 years [ ] Christian between 5-10 years

[ ] Christian between 1-5 years [ ] Christian less than a year

[ ] Not a Christian, but seeking

Are you a member of this church?

[ ] Yes [ ] No [] In/planning to take New Connections

What is your current occupation?

Thank you very much for your assistance and participation in this survey. 


\section{APPENDIX 4 \\ HBC FOLLOW UP SURVEY ON BIOETHICS}

Take this survey only if you are 18 years of age or older

I did __ did not __ take the first survey.

I have attended these talks on bioethics:

[ ] Carried All the Way (last Sunday am)

[ ] Baby Making in the (not too Distant) Future (last Sunday pm)

[ ] Biblical Principles and the Culture of Death (this Sunday am)

[ ] End of Life Treatment and its Limits (this Sunday pm)

These messages have (Check all that apply):

[ ] Turned me off from bioethics

[ ] Done nothing to improve my understanding of bioethical issues

[ ] Made me more convinced that the church has no business addressing these controversial and personal issues.

[ ] Given me a greater understanding of the term "bioethics "

[ ] Made me more aware of issues that are bioethical in nature

[ ] Given me a greater awareness of the prominence of bioethics in our culture

[ ] Helped me see how the Bible and theology applies to bioethical issues.

[ ] Given me a greater appreciation for the concept of the "sanctity of human life" as a guiding principle in bioethical decision making.

[ ] Increased my desire for more bioethical education and discussion

[ ] Stimulated me to research bioethical issues on my own

[ ] Made me desire more bioethical education through my local church

[ ] Stimulated discussion in my family on bioethical issues

[ ] Made me more committed to teaching my children and grandchildren about bioethics and the sanctity of life.

[ ] Have heightened my awareness of bioethical issues in everyday life like news reports and issue son brought up in TV programs.

How do you think bioethical education should occur in the local church? (Check all that apply)

[ ] It shouldn't (please explain why if you select this)

[ ] It should occur more frequently from the pulpit

[ ] It should occur regularly as a life-training elective 
[ ] I would like to have a series on bioethics in my ABF

[ ] Bioethical issues I would like to see addressed through our church's educational ministry include

[ ] I would like to see books on bioethics in our library and for sale in the bookstore

[ ] I think an MTW centered around bioethical issues commonly faced would be appropriate

[ ] We should have bioethical counseling services for people facing infertility, end of life dilemmas. etc.

My views have changed on (Check all that apply)

[ ] When human life begins

[ ] The sanctity of human life

[ ] Assisted reproduction issues

[] End of life issues

[ ] When it is or is not right to withhold or withdraw treatments with the terminally ill.

[ ] My views have not changed (see next question).

Although my views have not changed on any particular issue(s) I have received information that has helped me explain and/or defend my views more adequately regarding. (Check all that apply)

[ ] When human life begins

[ ] The sanctity of human life

[ ] Assisted reproduction issues

[ ] End of life issues

[ ] When it is or is not right to withhold or withdraw treatments with the terminally ill.

Please feel free to comment or provide constructive criticism to what you have heard in the last four sermons.

Demographics

Christian for how long? yrs. Not a Christian

Occupation?

Church member? Yes No

Highest education? 


\section{APPENDIX 5 \\ THIRTEEN WEEK ELECTIVE HAND OUTS \\ Handout One: Syllabus}

A Story to Love, A Story to Live: Moral Discernment in the Light of Biblical Narrative

Description: In this elective, we will explore together what shape our thought and lives might take as people striving to be faithful to God in view of current bioethical challenges. We will explore issues which have emerged and are emerging due to new medical knowledge and powers that promise increasing levels of control over our procreation, health, sickness, suffering, healing, aging and dying. We will work to discern a response that reflects biblical faithfulness in these critical and common experiences of life.

Schedule:

Session One: Introduction: Bioethics and the Local Church

Session Two: "Story" and Community as the Context for Bioethical Discernment

Session Three: Living the Story Together: Communal and Biblical Discernment in Bioethics Session Four: Living the Story in our Procreation, Pt. 1

Session Five: Living the Story in our Procreation, Pt.2

Session Six: Living the Story in our Health

Session Seven: Living the Story in our Sickness and Suffering, Pt. 1

Session Eight: Living the Story in our Sickness and Suffering, Pt. 2

Session Nine: Living the Story in the World of Medicine, Pt. 1

Session Ten: Living the Story in the World of Medicine, Pt. 2

Session Eleven: Living the Story as We Age

Session Twelve: Living the Story in our Dying and Death, Pt. 1

Session Thirteen: Living the Story in our Dying and Death, Pt. $2^{34}$

Recommended Reading:

1. Holy People Holy Lives: Law and Gospel in Bioethics by Richard C. Eyer. 2000, Concordia Publishing House

${ }^{34}$ Note: These thirteen sessions reflect the originally planned syllabus, which, as explained in Chapters 3 and 5, I did not complete as scheduled. In the spring, I continued and was able to cover the rest of the material, but it was not part of the Project proper. 
2. "Bioethics: Obstacle or Opportunity for the Gospel?" Lausanne Occasional Paper (LOP) No. 58, by the Lausanne Committee for World Evangelization, 2005.

(available through their website - http://www.lausanne.org)

3. Stewards of Life: Bioethics and Pastoral Care by Sondra Ely Wheeler. 1996. Abingdon Press.

4. Faith, Formation and Decision by James M. Childs Jr. 1992, Fortress Press

5. Remembering Jesus: Christian Community, Scripture and the Moral Life by Allen Verhey. 2002, Eerdmans.

6. Reading the Bible in the Strange World of Medicine by Allen Verhey. 2003.

Eerdmans. 


\section{Handout Two: Introduction, Bioethics \\ and the Local Church}

1. Explain the concept of "bioethics" as you understand it presently.

2. In light of the "critical and common experiences of life" mentioned in the course description, identify the bioethical issues inherent to those experiences.

3. Which of these issues most concern you as an individual? Please explain.

4. Of these, what, in your opinion, are the issues and challenges of bioethics that are of greatest concern today to:

- The culture

- The Church

5. Is there a difference between how the church and the culture perceive the challenges of bioethics in our world today? If so, what do you think is the basis of this difference?

6. Read the following statements:

For three thousand years at least, a majority of people have considered that human beings were special . . . it's the Judeo-Christian view of man. What the ability to manipulate genes should indicate to people is the very deep extent to which we are biological machines. The traditional view is built on the foundation that life is sacred. ...Well, not anymore. It's no longer possible to live by the idea that there is something special, unique, even sacred about living organisms. (Haynes 1993)

During the next 35 years, the traditional view of the sanctity of human life will collapse under pressure from scientific, technological, and demographic developments. By 2040, it may be that only a rump of hard-core, know-nothing religious fundamentalists will defend the view that every human life, from conception to death, is sacrosanct. (Singer 2005)

Human nature itself lies on the operating table, ready for alteration, for eugenic and neuropsychic "enhancement," for wholesale redesign. Anyone who cares about preserving our humanity, the time has come to pay attention. (Kass 2002)

The most significant threat posed by contemporary biotechnology is the possibility that it will alter human nature and thereby move us into a "post-human" stage of history. (Fukuyama 2002)

We stand at a threshold: if we aggressively pursue any or all of several technologies now before us, we may alter our relationships not with the rest of nature, but with 
ourselves. First, human genetic engineering and then advanced forms of robotics and nanotechnology will call into question, often quite explicitly, our understanding of what it means to be a human being. (McKibben 2003)

What, in these statements, most gets your attention? Why?

Based on these secular statements, why should the church be interested and involved in bioethics?

7. In your opinion, how has the Church, in a general sense, done with regard to addressing bioethical issues?

Been doing just fine

Needs some improvement

Good in some issues, poor in others

Has been silent

Engaged and enlightening

Is poorly equipped

Has been incompetent

Has been uninformed

Has been uncaring

Head in the sand

How do you think this affects the culture? What about the church itself?

8. Christian bioethicist C. Ben Mitchell has written:

Because medical ethics is about moments in every human life, and because God is the author of every human life, there should be great concern in the church about medical ethics and, more comprehensively, bioethics." And, "Christians can no longer pretend, as it appears they may have in the past, that these dilemmas do not have implications for every believer. (Mitchell 1995)

Explain why you agree or disagree with Mitchell.

If you agree, what would you say is the remedy within the local church?

9. Christian bioethicist Nigel Cameron has remarked as follows concerning bioethics education in the local church.

It is remarkable ... that so many Christians seeking help in having a child fail to grasp the moral significance, for example, of reproductive technology, and find themselves led through referrals into using in vitro or surrogacy or some other questionable benefit of the new technology - with no context for their decision set in Christian education within the local church. It is hard to see how any church could avoid addressing the bioethics agenda ... throughout its educational task. (Cameron 2000) 
What is your initial reaction to Cameron's statement? Explain your answer(s). Too harsh

Spot on!

Not realistic

Uninformed

Out to lunch

Realistic

Practical

Partially right

If you find yourself in general agreement with Cameron, what, in your view, is the needed "context ... within the local church" for helping Christians in making these kinds of decisions?

10. Next week we will discuss how the idea of the "story" of biblical narrative provides such a context. For now, what is your understanding of the Title of this elective, A Story to Love, A Story to Live: Moral Discernment in the Light of Biblical Narrative? 


\section{Handout Three: Addendum, Answering Objections to Bioethical Education in the Local Church}

Introduction:

Is bioethical education obligatory in the local church? Some no doubt hear the word "bioethics" and perhaps think of one or several objections. Perhaps the most prominent is that it will distract the church from its real priority; evangelism. Some may also think that it is too academic, meaning that most people in church are not educated enough to deal with its complexity. Others might consider it too political, and thus having no place in church where we don't mix sacred theology with secular politics. Certainly some object that bioethics is way too controversial and, being such an area where opinions even among God's people may so vary, should be left alone. Finally, there is the quite tenable objection that bioethics surfaces issues that are far too personal to discuss in a local church. Let's look at each of these in turn.

\section{Bioethics is not evangelistic}

The Great Commission is about evangelism, but also education (Matthew 28:1920). We are to edify and minister to one another in the body of Christ (Eph. 4:11-16), and we all face issues of procreation, birth, health, sickness, suffering, healing, aging, dying and death; including people in the world, this opens opportunities for Gospel witness.

When people encounter infertility, illness, and the fragility of their own bodies, and when they confront their own mortality as they observe or experience the dying process, the illusion of control over their lives is threatened or even shattered. Where will such people turn for help with their questions and the decisions they must make about medical treatments? If Christians become known as reliable and thoughtful sources of information and counsel about these issues, opportunities to present a Christian view of life, meaning, suffering and death will arise. The questions at the heart of bioethics are also at the heart of the gospel. (Lausanne Committee for World Evangelization 2005)

\section{Bioethics is too academic}

Bioethics cannot be left to the academic world insofar as it has to do with the most primal experiences of every human life. Since we all face these moments form conception to death, bioethics is for all of us.

Christian bioethics is fundamentally an ethics of the whole people of God. Ethical discernment is a corporate activity, and is not just a matter for a select band of clever professional bioethicists considering bioethical studies . . . And just as this discernment is not just a matter for bioethical elite, so it is not limited to an ecclesiastical elite." (Song 2005) 
3. Bioethics is too clinical

Why did the followers of Christ care about medicine in the first place?

Because of Jesus the Great Physician (Mark 4:23) and the Great Patient (Matthew 25:3640).

But with medicine, there naturally comes reflection on what is ethical (consistent with the Gospel) and what is not. (Example: The Hippocratic Oath.)

Long before there were hospitals and clinics, Christians were involved with caring for the sick in ways not found in the pagan world; reaching out to the outcasts and contagious sick, abandoned infants and lepers; those rejected by society. They saw this as a moral mandate in light of the person of Christ (Verhey 2003).

4. Bioethics is too political

The church itself is a political institution. References to "kingdom", "Lord (kurios)," "citizens (polites)" and "city (polis)" are all political metaphors intended to draw our attention to the nature of the church as a political body.

Attempts by Christians to avoid political involvement because of the 'dirty' nature of politics are rightly condemned as irresponsible, if not unfaithful. Rather, it is the task of Christians to be politically involved exactly because we recognize that our politics involves compromise and accommodation. To withdraw from the political in order to remain pure is an irresponsible act of despair. (Hauerwas 1981)

Christians must participate in what is already an international conversation on the part of nearly every literate sector of society about what humanity will look like once we become fully fluent in the lexicon of human genetics. For persons of biblical faith to play a constructive role in that conversation will test out theological depth, scientific literacy, moral vision and political savvy. (Stassen and Gushee 2003)

5. Bioethics is too controversial

People come to church for comfort and consolation, not to be confronted with difficult moral problems. "I don't know why we are talking about such things in church, we have a happy, friendly congregation here ... we like to come to church and hear the good news. If we start talking about issues like these, it will only divide us and spoil our peaceful congregation," said one man after a talk on a controversial ethical issue. 
Sometimes churches would prefer to avoid hard conversations about hard choices; hard moral choices, after all, can sometimes tear a community apart. No wonder, then, that churches are sometimes inhospitable to conversations about those choices. (Verhey 2002)

Christ's community is a community of diversity, not uniformity. If we do not collectively discuss the bioethical issues that shape our time within the context of our faith, we are left to struggle, and even suffer, on our own with some of life's greatest questions and challenges. "Unless we make the connections [of ethics to our faith] ourselves we must carry on those struggles without the benefit of understanding how our faith and hope in Jesus Christ can provide the moral compass we require" (Childs 1992). In failure to address these issues, "we not only avoid certain aspects of our calling as Christian witnesses in the world, but also deny each other the gifts we can bring to the task through sharing in the congregational community" (Childs 1992).

\section{Bioethics is too personal}

This is actually a very legitimate concern, and the most plausible objection. Much of the reason that bioethical issues become controversial is that people who have faced or are facing serious bioethical challenges, like the pregnant teen, or the post-abortive woman who has suffered with guilt for years, or the couple that had in-vitro fertilization (IVF) treatments several years ago but now has no clue what happened to the unused embryos, and no way of finding out, understandably wish to avoid the critical eyes and words of their fellow members. They do not feel comfortable or safe turning to their community of faith with their struggles because they anticipate only harsh condemnation toward their moral failures, rather than loving support

It is unfortunate that churches create such an atmosphere of fear. This apprehension leads God's people to keep their personal bioethical issues shrouded in secrecy and even suffering, leading to a shallowness of growth in some of the most important questions we face individually and collectively. As churches focus more on bioethics, and thus highlight the biblical doctrine of the sanctity of human life, they should expect a response of guilt from some who consider their past bioethical choices to be moral failures. Here, the redemptive message of God's love and grace must abound in the church. We are all moral failures, and we should reach out redemptivley to those who are struggling. An atmosphere of love, acceptance and forgiveness in the church, where God's people can safely speak of their bioethical struggles, is a vital part of developing an environment where bioethics takes a more prominent role in local church ministry. 


\section{Handout Four: "Story" and Community as the \\ Context for Bioethical Discernment}

\section{Story}

The Christian worldview is a grand story, a metanarrative that explains and encompasses all other stories, including the stories of our lives. It is the story that helps us see the big picture, the direction that history is headed, and how we fit into its unfolding drama.

Is it generally good or bad to speak of the Bible as a story? Explain.

The word "story" is actually an abbreviation of the word "history" which comes from the Latin historia which means "narrative, account, tale." The word "story" as first used in the 13th century meant "an account of some happening." Originally it meant a recital of true events, and then in the 14th century took on the idea of a fictitious tale told to entertain (Online Etymology Dictionary, http://www.etymonline.com/index.php s.v. "story").

Postmodernism militates against this idea of a story that encompasses all other stories. It is called a metanarrative and important post modern writer Jean-Francois Lyotard states, "I define postmodern as incredulity toward metanarratives. This incredulity is undoubtedly a product of progress in the sciences: but that progress in turn presupposes it" (Lyotard 1979).

So what is a metanarrative?

Meta - prefix which means "higher," "above," or "about."

Narrative - literally a "making known" a recounting or relating or explaining.

Thus a metanarrative is an explanation higher than or above the narrative itself. It is a "story about a story, encompassing and explaining other 'little stories." (Wikepedia, http://en.wikipedia.org/wiki/Metanarrative s.v. "metanarrative"). A metanarrative is a master story which serves as the framework for understanding the world and one's place in it. We will define it as the master story that encompasses and explains all other stories.

Evangelicals are writing, more recently of seeing the Christian worldview precisely as a metanarrative as essential to an understanding of the Bible and the biblical worldview.

What can we learn about metanarrative from the following scene in Pirates of the Caribbean?

D.A. Carson speaks of: 
The importance of adopting "the whole counsel of God," and recognizing the distinctiveness of an entire Christian worldview if the parts within it are to make much sense. That means not less than following and adopting the Bible's plot-line. In other words . . . the Bible provides us with a metanarrative, a comprehensive "story" that provides the framework for a comprehensive explanation, a . . . worldview. (Carson 1996)

James Sire, in fact, has more recently defined a worldview as, "A way of life that is bound up with seeing one's life as a part of a master story, a metanarrative (Sire 2004)," and asks, "Does it not miss an important element in how people actually think and act . . . would it be better to consider a worldview as the story we live by" (Sire 2004 emphasis his)?

He also writes, "When we accept this story in the fashion God has intended, we do so not just as an intellectual assent. We do not just believe it at a distance. We are to indwell it as if it were our own story, because it actually is" (Sire 2004 emphasis his).

How can seeing worldview as metanarrative change the way we see ourselves and how we live our lives? In what way can the biblical narrative be "the story we live by"?

"When Christianity becomes something other than entering into and living out the story of God, it becomes something other than Christianity. God's story isn't over; it's still being told today" (James 2006).

How do you respond to this more poetic sentiment of Steven James as it relates to this topic? "Ah, sweet story teller, speak your tale into my heart so that my life might finally make sense" (James 2006).

\section{Community}

What are the things that make the Christian community distinct or unique?

The Christian community is not defined by those who behave in some particular way ... nor is it made up of those who hold some particular moral opinion or group of them, whether these be convictions about abortion . . . or about any of a range of other serious and important issues. Instead, the Christian church consists of those people who believe the things that Christians affirm, which are in the first instance not moral statements at all, but rather, affirmations about what God has done, not about what we must do. (Wheeler 1996 emphasis hers)

Richard Eyer holds that story "is a more basic and more enduring foundation on which to establish ethics" because it "gives coherent meaning to our life together" (2000, my emphasis). "As Christians we need not concern ourselves merely with what to do or not to do. Rather, we keep our eyes on what God has done ... and continues to do [the story], not primarily about what we do" (Eyer 2000). 
What does the word "remember" bring to mind?

Read Exodus 20:2-3 and 8-11 to help answer this and also try to explain the relationship between community, story, memory and ethics.

[Biblically] memory is not simply a mental process of recollection, not just a disinterested remembrance of objective historical data; memory is to own a particular history as one's own, to own a past and to own it as constitutive of identity and determinative for [moral] discernment. In the New Testament and in the church there is no identity apart from memory, and no community apart from common memory. (Verhey 2003)

What are your initial reactions to this statement by Verhey?

How do story and community relate to each other in the forming identity and determining moral discernment?

\section{Conclusion:}

When we come to the biblical text seeking (bio)ethical wisdom and guidance, we must first and foremost acknowledge that it is a worldview and ethic presented not so much propositionally or systematically as it is a metanarrative with profound moral implications. Further, it is a narrative that forms a distinct community, which remembers, cherishes and retells that story. This Story forms, informs and transforms the community to become more increasingly what it should be; a community reflecting in its conduct the character of the very God who called it into being. Bioethics, any ethics, which are faithful to the biblical narrative, involves "remembering" this Story and what it means for us as a community.

Next week we are going to go into depth on the core of this biblical metanarrative and how it is, in fact "determinative for moral discernment." 


\section{Handout Five: Living the Story Together Communal and Biblical Discernment in Bioethics}

"The Bible as a whole document tells a story, and, properly used, that story can serve as a metanarrative that shapes our grasp of the entire Christian faith" (Carson 1996).

Christian bioethics is based on the self-revelation of God in Jesus Christ, witnessed to by the Old and New Testaments. The community of faith transmits the tradition of God's saving acts in history, culminating in the story of the life, death, resurrection and ascension of Jesus of Nazareth. This story provides the framework within which Christians interpret the world and their relationship to it." (The Lausanne Committee for World Evangelization 2005)

The Megathemes of the Master Story (God's BIG STORY).

I. CREATION. God made all things, but made humans in His image, giving them a special dignity and worth. Humans were made for an intimate relationship with their Creator and with a very particular role in His world. (Gen 1:1; Ex 20:11; Ps 8:5) Bioethical Implications:

II. CORRUPTION. Humans through their disobedience, and their lust for autonomy in determining good and evil for themselves, became sinful and brought a CURSE to the whole earth and CONDEMNATION to themselves. Death and depravity resulted in and spread throughout the human race. (Gen 2:17, 3:16-19; Rom 5:12, 8:20, 22)

Bioethical Implications:

III. COVENANT. God seeks to restore the relationship with humans through establishing special arrangements with them, so that He, a holy God could dwell with sinful humans. First He REDEEMS and establishes His CHOSEN NATION - ISRAEL, through whom he would bring His CHOSEN MESSIAH - CHRIST, through Whom He would eventually redeem THE WORLD, as He purposed from the beginning. (Gen 12:1-2, 17:7; Ex 24:7-8; Lev 26:11, 12, 45, 1 Chr 16:15-17; Jer 31:31-33; Matt 26:26-28) Bioethical Implications:

IV. CONSUMMATION. The end of all things in which God will put everything right again and establish His kingdom in the New Creation (New heavens and new earth - Rom 8:19, 21, 23; $\operatorname{Rev} 21: 1-3,22: 3)$

A) The reverse of the CURSE

B) The restoration of CREATION. 
C) The coronation of CHRIST!!

Bioethical Implications:

V. CHRIST. The centerpiece of the biblical narrative; the unifying theme of the whole story. The One in whom all history, both cosmic and earthly, is summed up. The One whose story, from conception to death, is our moral model, and the basis of our moral discernment as His followers. (Eph 1:9-10; Phil 1:27; 1 Pet 1:20-21; 1 John 2:6)

Bioethical Implications:

Biblical faithfulness in bioethics must take into account the biblical narrative summarized in the megathemes of Creation, Corruption, Covenant, Consummation and Christ. This is the framework for our "remembering" the biblical story and thus the context for all of our practical discussion and discernment as a local body of believers seeking to make Christ honoring bioethical decisions. This is what bioethical education in the local church all comes down to.

In Christian community ... discernment regards decisions as the recognition of what is fitting, or coherent, with the cause that God has made known in a narrative in which Christ is the center" (Verhey, 2003, 61), and "in the light of that story Christians struggle to understand God and all things . . . in relation to God. In the light of that story Christians struggle to shape their lives into something worthy of the gospel. (Verhey 2003)

This final point is critical to understanding the process of moral discernment within the body of Christ. It involves living a life "worthy of the gospel" as Paul called the Philippians to do (Phil 1:27). For Paul, the gospel was not merely something that a sinner hears to get saved, but was an entire worldview, a perspective on life. The Gospel is the metanarrative that formed and continues to transform the Christian community. Christians are to live a life faithful to, worthy of, the gospel of Christ. But the "gospel of Christ" only makes sense in the context of the scheme of our being created beings who are corrupted, and in need of covenant and who, having united with God in covenant through the gospel of Christ, anticipate the final consummation. As we shall see, these themes are central to bioethical discernment. 


\section{Handout Six: The Practice of Bioethical Education \\ in the Local Church}

I. Community, Narrative and Ethics

A. The Character and Force of Community and Biblical Narrative Ethics

Christians must learn ... how bioethics may take the form of a response to the action of God in Jesus Christ ... they must learn how bioethics flows out of worship and is embodied in the life of the Church community. (Song 2005)

B. The Main Character and Face of Biblical Narrative Ethics

1. Ethics as imitation - Lev 11:45; 1 Pet 1:15; 1 John 2:6; Ephesians 5:1

To know the love of God and trust in it, is to become a people of love. To know the mercy of God is to become a people who are merciful. To know the creator God who cares for the earth and everything that is in it is to become a people who are good stewards of that creation. To know God in Jesus Christ as the one who gave himself up for all people is to be a people ready to receive and affirm the worth of all people, even our enemies. To know God in Jesus as the creator and redeemer of all life is to be a people who uphold the value of life. In these and many other ways we ... become a people whose choices in life for the right and good are a reenactment of God's action in our life. (Childs 1992)

2. The Gospel - Incarnation and Imitation of God

3. Remembering God's actions -

II. The Church as Moral Community

A. The Privilege and Priority of Moral Community (Rom 15:4; Col 3:15; Eph 4:11-12)

"We really do need each other. The lonely pursuit of the moral life is an exercise in despair; none of us has what it takes to understand all that needs understanding and do all that needs doing. It is part of the good news of our salvation in Jesus Christ that our salvation is not an individual happening but that the grace of God has created us anew in community, intimately linked to each other as the body of Christ." (Childs 1992) 


\section{B. The Parameters of Moral Community}

The church needs to grow as a place to "nurture and sustain the congregational practice of moral discourse and deliberation and discernment - specifically about bioethics - by attending to and engaging in the practice of reading Scripture" (Verhey 2003).

1. Moral Discourse - The activity of discussing and praying about matters involving conception, pregnancy, birth, life, health, sickness, disease, disability, dying and death; and what should be done and left undone with regard to them.

2. Moral Deliberation - The process of giving and hearing reasons for the choices we have made or intend to make with regard to these areas.

3. Moral Discernment - Seeking to align or fit what we do and what we leave undone in these matters to the Story of Scripture, especially the Gospel of Jesus Christ as the culmination of that Story.

Discernment is that standard of excellence that is the ability to recognize "fittingness." In reading Scripture, discernment is the ability to recognize the plot of the story, to see the wholeness of Scripture, and to order the interpretation of any part of it toward that whole. It is to recognize how a statute, a proverb, or a story "fits" the whole story. And in reading Scripture as "useful ... for training in righteousness" (2 Tim. 3:16), discernment is the ability to plot our own lives in ways that 'fit' the whole of Scripture, the skill to order our lives toward that whole. (Verhey 2003)
a) Living "worthy of the gospel of Christ" (Phil1:27)
b) The "gospel" -
c) Living "worthy of the gospel" -
d) "Remembering" Jesus -

4. Moral Decision - The actual making of a choice regarding these matters based upon the insights gained through the process of discourse, deliberation and discernment with the ultimate view of honoring God and witnessing to His moral will in the community of faith and the world around us.

a) What significance does Rom 7:21 have for our ethical decision-making?

b) Living simultaneously as saint and sinner 
c) Living in the tension between the "bondage of corruption" and the blessings of covenant

d) Ambiguity and ambivalence - (decision making in a fallen world-Corruption)

e) Forgiveness and redemption 


\section{Handout Seven: Practical Exercise}

Instructions: Read this and think about the things that need to be addressed from the perspective of God's Story. Assuming that these people want to be faithful to God's Story, think of how biblical faithfulness would look for them. Be prepared to discuss this next week.

One Couple's Procreation Story:

(From The Lausanne Occasional Paper No. 58, Bioethics: Obstacle or Opportunity for the Gospel?)

Evening is falling when Suzanne finds William. The doctor has just told her she is not pregnant and, indeed, could not become pregnant. Something is wrong with her body. She has been told her womb is fine, but she has no eggs that could live. A tear is in her eye as she says to William having children is natural. It is what all couples should do. It is what God wanted when he said 'Be fruitful and multiply.' William says 'I love you no matter what. We'll see what options there are.'

After three weeks, at the recommendation of their family doctor, William and Suzanne visit a specialist at a city clinic. The specialist offers several options. 'You can, of course, go home and accept this is nature's way. Or you could adopt. Though this would not be your child genetically, no doubt you would grow to love the baby. Or we could try an assisted reproductive technique. We'd take eggs from a donor and fertilize them with William's sperm. At that stage you could choose the sex of your child too, if you want. We would then pick the best few embryos and insert them into Suzanne. The ones that grow best will be kept in the womb.' On the ride home, the couple decide they should go ahead. Suzanne says 'At least our baby will have part of our genes and I will be able to feel him grow in me. That way he is part of both of us.' 'Let's pray about it, but I think this is a good idea', William responds 'and if you want, we can talk it over with the pastor.' 'No, not yet, let's keep this to ourselves, at least for now' she replies.

After eight months, though still not pregnant, the couple have an argument about who should know what. William says 'Sweetheart, this is simply how some people have children nowadays. Of course we can tell your parents and mine...and, of course, we will tell the baby when he - and the doctor said he could select the sperm so our child should be male - when he is old enough.' Suzanne replies 'There is no way we are going to tell anyone about this. It is between us and the doctor.'

It is two years later, driving home from the specialist having been told once

again that the procedure has failed, that William asks Suzanne if this is not God telling them the whole thing is wrong. They have spent a lot of money and have even been told by the doctor that he could allow them only one more try. Once again Suzanne is crying. 'Should we adopt? There are babies in our country and throughout the world who need parents. We could love a baby, I know.' They drive home in silence.

1 . What are the issues that this story raises?

2. What is especially problematic assuming this couple is Christian and is seeking to do God's will? 


\section{Handout Eight: Procreating in His Image and Ours}

In the Story, no sooner do we learn of our Creator than we learn that he created humans with the task of multiplying and filling the earth with more of His image bearers. Humans were to procreate offspring, in their image and thus perpetuate God's image, in which they were created, in God's world. God had no intention of creating from dust anymore once He created Adam and Eve, so God gave them the responsibility and ability to engender more image bearers. This renders parenthood a sacred vocation. Taking the following narratives in the Story at face value gives rise to certain presuppositions about marriage, sexuality, procreation, and family to include:

P1. Humankind is a direct creation of God in His image and likeness as male and female; i.e. as sexual counterparts (Gen 1:26-27).

P2. Man was created prior to woman, who, having been subsequently created to fill his need for companionship is brought to him in marriage and "one flesh" sexual union (Gen 2:18, 21-25, and 1:28).

P3. Male and female, as complementary sexual counterparts, are charged with the responsibility of procreation and earth population (Gen 1:27-28).

$\mathrm{P} 4$. The sexual union of a husband and wife is the means by which God ordained that children be engendered and that families be built (Gen 4:1-2, 17, 25).

P5. Procreation is a result of divine-human collaboration (Gen 4:1, 25; also see 29:31, 33; and 30:22-24).

P6. Human procreation is modeled after divine creation. Children engendered through the sexual union of fathers and mothers bear the image and likeness of their human procreators just as humans bear the image and likeness of their divine creator (Gen 5:1-2).

P7. Just as God blessed humans created in His image by providing a place conducive to their surviving and thriving, and subsequently pursuing a filial relationship with them, likewise should men and women (fathers and mothers) who procreate ensure conditions for the survival and nurturance of the offspring procreated in their image (Gen 1:28, 2:15-17, 3:8-9).

While these presuppositions may seem to come across as so foundational as to render their enumeration unnecessary, these are the very truths that are threatened by many modern biotechnologies surrounding contraception, assisted reproduction, cloning, genetic screening and abortion. This being the case, Christian men and women who participate in certain reproductive biotechnologies may inadvertently be contributing to the erosion, if not eradication, of sexuality, marriage and family as God designed it. Bioethics involves the evaluation of the biotechnologies developed to address issues of human sexuality and procreation, biblical bioethics does so in the context of the Story God tells.

This undertaking in the church is critical for our times because, "The revolution in reproduction is not merely a technological achievement. It inevitably raises ethical issues. There is a tendency to divorce technology from any moral scrutiny, and this is 
particularly true in the case of reproductive technologies" (Hollinger 2000, 79). Lammers and Verhey frame the questions of greatest concern as follows.

The technological control over procreation is not revolutionary because large numbers of children are born with the help of these technologies. It is revolutionary because it requires a revisiting of some fundamental questions about the significance of human sexual relations, about the responsibilities that attend such acts as begetting, about the meaning of becoming and being parents, about the appropriate disposition toward children. Issues of great human importance are at stake in the way we tell-and live-the story of our parenting. (Lammers and Verhey 1998, 465)

What follows is a raising of issues and questions in light of the above presuppositions (P1-P7) surrounding human sexuality and procreation, questions which, frighteningly, represent viable options to family planners due to current biotechnology. Any reference to the biblical narrative will be abbreviated "the Story," and all the individuals confronted with the questions are assumed to be men and women who desire to remain faithful to the Story.

Concerning P1 the only statement about humans in the Story are that they are created as "male" and "female." These words do, in fact, draw attention to the anatomical compatibility and function of the sexes, but in light of this principle how should hermaphrodites be treated? Should these individuals, who have not chosen to be born as they are with both male and female sex organs, be forced to choose one gender over another, and should they even be given that opportunity to choose it seeing that non-hermaphrodites did not? If not, who should select it? What about women and men who feel they have been trapped in the body of the wrong sex all their lives and desire sexual reassignment surgery? To what extent must we be content with the gender with which we were born? Should Christian surgeons and nurses living the Story perform the surgeries or attend to the patients who undergo them?

Regarding P2 what should happen if a man and woman, who have waited to become sexually active because of their commitment to the Story, discover that they are sexually incompatible due to anatomical issues? Should they seek surgery to correct the problem? Should Christian physicians and nurses perform the surgeries or attend to the patients? Further, if medications are called for to enhance or maintain a man and woman's sexual activity, does this fit with the Story? Is the use of Viagra, or other male enhancements, permissible and appropriate for those who are committed to the Story?

P3 puts us into more familiar territory as far as issues go than the questions raised under P1 and P2. Should every act of sexual intercourse have the potential for procreation, or is it consistent with the Story to take measures to forestall children and plan and control family size? Is sex for recreation and pleasure alone a position a husband and wife who are committed to the Story should take? Is limiting the number of children a couple has consistent with the Story? Is it consistent with the Story if a couple gets married and has no plans for children at all? If planning a family in terms of size and spacing of children is compatible with the Story how should couples go about doing it? Are there any contraceptive devices or drugs that are inconsistent with the Story? What criteria should be used for determining this? Are surgical contraceptive procedures like tubal ligations and 
vasectomies appropriate for those who want to live a life faithful to the Story? Is abortion ever a viable option for a woman committed to living the Story; for example if she is raped or her carrying to term could result in her death, or having another child could compromise her maternal care to her present children? If a couple discovers they are unable to procreate, how far along with assisted reproductive technologies can they go before they are stepping outside the Story? Is it different for different people, or are there absolute lines that must not be crossed? If so, how would the Story help us to discern those lines?

$\mathrm{P} 4$ raises question like would it be acceptable to use donor gametes, or to donate one's gametes to assist infertile couples? Is surrogate mothering, or any other third party fertility assistance in line with the Story? Is it consistent with the Story to deliberately sever procreation from parenting which most modern ARTs do? Other issues that arise in light of this Story are whether cloning is consistent with it seeing that men and husbands are not needed for this procedure, and whether women who have lost their husbands to death should extract or use previously extracted sperm posthumously in order to have children by their husbands. In the future, we may be asking whether the Story allows for ectogenesis, when the artificial womb replaces the mother's altogether. Is the use of in vitro fertilization to assist lesbians and gay men to become parents in line with the Story, since the biblical narrative makes it clear that a married man and woman are the intended agents of procreation? Would Christian doctors and nurses maintain integrity to the Story if they assist in these procedures?

With regard to P5 we could raise queries like whether the use of technology to assist in procreation is ever consistent with the Story, seeing that God is sovereign over the womb and life and death. This of course raises questions about technology in general. Is technology always "playing God?" If not, when do we start assuming a divine prerogative inconsistent with the Story when utilizing technology? Can we still maintain a mentality of collaboration with God and use assisted reproduction technologies?

P6 and P7 surface other concerns about third party assisted reproduction but from a different angle. Should we care that embryos generated in a lab have a genetic imprint, although unique, that still reflects a man and woman donor's somewhere in this world? Should anonymous donors care about embryos so generated from their gametes? Can a young man or woman not ready to have children, or not intending to have children, remain faithful to the Story and donate their gametes? Does a child have the right, or need, to know her biological parents; the ones from whom they received their image? Is image an important matter to begin with? Should there be any concerns when children generated through in vitro fertilization from anonymously donated gametes grow up and wonder who their real mother and father are, or if they find their half siblings generated by half the same gametes on the other side of the country and they happen to look like each other and wonder together whose they are?

P7 also brings up some issues all of its own. Should the plight of leftover embryos be the concern of couples who have successfully used in vitro fertilization but in the process generated more embryos than they ever plan to use? Is it consistent with the Story to give the unused embryos to another couple to raise them? If so, should that be anonymous (possibly resulting in children not being raised to love and live the Story) or open? Should donors care about the physical, psychological and spiritual well-being of embryos they plan to have nothing to do with but that bear their image? Is the deliberate plan to have nothing to 
do with the humans generated from their gametes (naming them, providing for them, having filial relations with them, bringing them to maturity) consistent with the Story? Does the Story allow for genetic screening of embryos to select the more healthy ones, and concomitantly destroy those that are not? Does eugenics fit in with the Story if it means selecting some embryos for death, or designing children at the genetic level to give them the best chance in life? Does the Story leave room for human embryos to be generated for the sole purpose of biomedical research, seeing that they are generated to be killed for the greater good? 
Handout Nine: Issues at the Beginning of Life

The Moral Status of Embryonic Humans: Biological and Biblical Perspectives

I. When does life begin?

Introduction:

In light of major advances in technology which give us great power to generate, manipulate and destroy the human embryo we must endeavor to come to a clear and definitive position on the identity of the human embryo. The relevance of this endeavor cannot be over-stated, especially for Christians who may employ these technologies to convenience their lives, and who, biblically, must uphold the dignity of human life created in the image of God.

A. Why should we care about this question? (The "Hot Potato" Issues have to do with Embryonic Humans!)

1. Abortifacients ("medical" abortions) - Commonly used abortion inducing drugs are methotrexate, misoprostyl and RU-486. When used early in pregnancy they interfere with the growth of the human embryo, causing it to die. Use of these should be subject to the same serious reflection and rigorous debate as the many surgical methods used to induce abortions for unwanted pregnancies. Further RU-486 has had a short history in the US, but one involving serious complications and even death of the user in a few cases.

2. Emergency Contraception - This is the controversial "morning-after" pill, or "Plan B," which, when taken no later than 72 hours after unprotected intercourse, may do one of three things: 1) prevent ovulation 2) thicken cervical mucus to inhibit sperm from entering the uterus or 3) altering the endometrium (lining of the uterus) so as to prevent the implantation of an already existing human embryo. The controversy especially arises in relation to this last mechanism for preventing pregnancy, because it does not prevent life, it takes it away.

3. Artificial Contraception (Birth Control) - In actuality, most, if not all, "birth control" pills (as well as patches, rings and injections) work by one of the three mechanisms just listed. Few people are aware of this. Couples using (or considering using) these devices should inquire as to how exactly they work, especially if they are concerned that they might prevent implantation of a human embryo. It should be known that there is presently much disagreement among Christians and Christian doctors on this matter, and it is an area requiring conscientious decision-making on the part of sexually active couples who believe that "life begins at conception."

4. Artificial Reproductive Technologies (ARTs) - Especially any technology that utilizes in vitro fertilization (in which sperm and egg are joined in a dish in the laboratory 
and the viable embryo(s) implanted in the woman to assist pregnancy. The problem with this procedure, in particular, is that more embryos are generated than will be used. Many are (have been) frozen for an indefinite period of time. Researchers want to destroy these unwanted human embryos for Embryonic Stem Cell Research. (See \#6 below)

5. Pre-implantation Genetic Diagnosis (PGD) - One thing that happens in labs is the evaluation of embryos for their fitness for implantation. If one is found to be a carrier of a genetic defect that will result in a handicapped or mentally disabled child, the parents have the option to discard that embryo. This issue raises other questions regarding our attitudes toward the handicapped and disabled among us, along with those of life's value.

6. Embryonic Stem Cell (ESC) Research - An issue of great concern is whether or not to use the left-over, unwanted frozen embryos from IVF to harvest their stem-cells. Stem cells are the kinds of cells that are going to eventually become all the other specialized cells in the human body. Some believe (although there are to date no examples) that these ESCs can be directed to regenerate damaged tissue (like in the spinal cord, heart and brain) and heal multitudes of afflicted people with Alzheimer's, Parkinson's and Spinal Cord Injury, to name a few. More controversial is whether or not to actually generate embryos through IVF or cloning specifically for this purpose.

7. Therapeutic/Research Cloning - This procedure (called "therapeutic" by advocates and "research" by opponents) involves cloning an embryo in the lab for the express purpose of generating a clone that has all the genetic qualities of the one to be healed. This is being sought by some because the stem cells from left-over frozen embryos may suffer rejection from the host and cause other medical complications, whereas, theoretically, stem cells from a clone will not be rejected since they have the same exact genetic constitution having come from the person.

B. Basic Stages of Prenatal (before birth) Human Development

Every one of us began our existence as a:

1. Zygote (Lit. "yoke") - This is what we were called at the moment we began to exist as a new individual. This is what we are called once fertilization is complete and the 23 chromosomes from the sperm and the 23 chromosomes from the ovum (egg) unite ("yoke" together) to develop a whole new human being possessing 46 chromosomes (in most cases). Once we leave the single-celled stage, and divide into 2 cells (approximately 1 day) we are now called an:

2. Embryo (Lit. "swelling") - This is what we are called during that stage of development from two-cells up through the eighth week as we are growing (swelling) to the place where all of our organ systems are in place and functioning. After the eighth week we reach the stage in which we are called a: 
3. Fetus (Lit. "offspring" or "child") - Our fetal development, occurring from the $8^{\text {th }}$ week through to about the $36^{\text {th }}$ week (or ninth month) involves nothing other than increasing in size and preparing to leave the uterus and move to our next stage of human development; infancy.

This briefly explains how every single one of us began in this world, whether we were conceived in a woman's womb or in a dish in a laboratory. Then, after birth we develop from being an infant to a child to an adult. We do not really complete our human development and become a mature adult (from a biological developmental perspective) until approximately 25 years of age!

Although it is customary to divide human development into prenatal (before birth) and postnatal (after birth) periods, birth is merely a dramatic event enduring development resulting in a change in environment. Development does not stop at birth. Important changes, in addition to growth, occur after birth. The brain triples in weight between birth and 16 years. Most developmental changes are completed by the age of 25. Drs. (embryologists) Keith L. Moore and T.V.N. Persaud (Cited in Irving 1999)

C. When Does Human Life Begin?

- What kind of question is this?

- How should it be answered?

- Is it a scientific, legal, theological or philosophical question?

- Who is best qualified to answer it?

The question as to when the physical material dimension of a human being begins via sexual reproduction is strictly a scientific question, and fundamentally should be answered by human embryologists--not by philosophers, bioethicists, theologians, politicians, $\mathrm{x}$-ray technicians, movie stars, or obstetricians and gynecologists. The scientific experts, who are the experts on the issue of when a human being begins to exist, and on subsequent early human development from fertilization on are human embryologists. (Irving 1999)

It is unlikely that any of us would disagree with Irving's assessment of who is most qualified to tell us what the human embryo is.

So what do these true "scientific experts" say?

A zygote is the beginning of a new human being (i.e., an embryo).

Human development begins at fertilization, the process during which a male gamete or sperm ... unites with a female gamete, or oocyte ... to form a single cell called a zygote.

Dr. Keith L. Moore, and Dr. T.V.N. Persaud, (Cited in Irving 1999) 
The male and female sex cells or gametes, which will unite at fertilization to initiate the embryonic development of a new individual.

Dr. William J. Larsen (Cited in Irving 1999)

Every human beginning began his or her unique existence in this manner, as one cell. Dr. Raymond F. Gasser, (Cited in Irving 1999)

It is the penetration of the ovum by a spermatozoan and the resultant mingling of the nuclear material each brings to the union, that constitutes the culmination of the process of fertilization and marks the initiation of the life of a new individual.

Dr. Bradley M. Patten (Cited in Irving 1999)

Now we can say, unequivocally, that the question of when life begins is no longer a question of theological or philosophical dispute. It is an established, scientific fact ... all life, including human life, begins at the moment of conception. Each of us has a unique beginning; the moment of conception ... As soon as the 23 chromosomes carried by the sperm encounter the 23 chromosomes carried by the ovum, the whole information necessary and sufficient to spell out the characteristics of the new being is gathered.

Dr. Jerome LeJeune - Renowned French Geneticist Testifying in Davis v. Davis, Blount County, Tennessee Circuit Court, 1989

II. What is the human embryo anyway?

A. The human embryo is $100 \%$ human.

1. This is the kind of being that a human embryo is.

2. It is nothing other than, nor will it ever be anything less than, human.

3. "It" is really, without question, "he" or "she" from the moment of conception.

B. The human embryo is $100 \%$ living.

1. In fact it is a continuation from life, living sperm and eggs uniting to generate a living zygote and living embryo.

2. It has all the main characteristics of life, so its being "life" is a foregone conclusion.

3. The human embryo begins at the moment of conception, as a zygote, thus human life begins at conception.

C. The human embryo is a unique, and individual human being.

1. "Being" is the state or fact of existing or living. A "being" is "one who lives or exists."

2. To "exist" means to "live, to be present or have being." There is no question that an embryo is an existing human presence or being. 
3. What is present after human conception is a human embryo, no longer an egg or a sperm.

4. He or she is never a "part" of someone else's body, but instead its own separate body with its unique genetic make-up.

5. We should not speak of a "human embryo" as though it were a part of another human, like a "human arm," or a "human brain," but rather an "embryonic human," drawing attention to the fact of his or her uniqueness as a separate human individual.

D. To be an embryonic human is to be at the earliest phase of the human life-span, nothing less.

1. To be an embryo means to be at a particular stage, though immature, of development, the embryonic stage.

2. ALL_humans advance, barring any disease process or external forces of destruction, through a process of development beginning as a zygote, progressing to an embryo, then a fetus, an infant, a child, an adolescent and finally an adult, even if they began their existence in a Petri dish.

3. This human being is the same individual, with the exact same genetic identity, throughout all of these stages of development.

E. The human embryo is a distinct, self-directing, self-developing individual.

1. On account of its genetic endowment, every embryonic human possesses all the necessary genetic information to direct his or her own maturation and development. factors.

2. The maturation and development comes from within itself, not from external

3. Embryonic humans, like every other human, need a suitable environment and natural resources for him or her to survive and thrive. Deprivation of this environment or these resources will eventually result in death.

Key Point: To try to claim that the human embryo is anything other than human life is a display of pure scientific ignorance. If embryo destruction is justified, it cannot be because they are not living human beings since each embryo is exactly that. It would have to be that we place a different value on the human embryo than, say, a human child, but is this sliding scale for valuing humans justifiable?

III. What does the Bible say about embryonic and prenatal life?

A. Embryonic humans are "male" or "female" from the moment of conception, part of the uniqueness of being created in the "image of God." (Genesis 1:27) 
B. God is aware of, involved in and protective toward the developing, embryonic human, even before he or she is in a womb. (Job 10:8,10,11, 31:15; Ps 139:13,15; Jer 1:4-5)

C. Embryonic humans are intimately known by God and set apart by Him to special service. (Judg 13:5,7 Ps 22:10; Jer 1:5; Gal 1:15)

D. Embryonic humans are referred to both subjectively and objectively with personal pronouns. "He," "I," "You," etc.

E. Embryonic humans are referred to using the same terminology (Greek brephos) as infants (newborns), little children, as well as older children that can be educated. (Luke 1:44, 2:16, 18:15; 2 Tim 3:15)

F. To "conceive and bring forth" are considered as a whole regarding individuals lives, not separate and distinct events. The trimester breakdown is arbitrary. God sees an unbroken continuity between conception and birth. (Gen 4:1, 17; Judg 13:5,7 Isa 7:14)

G. Christ came into this world as a zygote, his incarnation began at conception (not birth), thus he identified with and sanctified every stage of human development from zygote to adult. (Isa 7:14; Luke 1:31 If God could be a human embryo, than a human embryo can be in His image)

H. As Christ was never without his distinctiveness as the God-man, so are we never without our distinctiveness as image bearers of God. To be human is to be in the image of God.

Note: While it may be argued that the Bible is not explicitly trying to make a case that humans in the earliest stages of development are in "the image of God" (i.e. "persons"), prenatal life, whether embryonic or fetal, is frequently spoken of with language that apparently presupposes this as true. These references are also made without any mention of particular stages of human development. This would seem to indicate that such stages, from the time of conception to live birth, are irrelevant to the question of whether embryonic or fetal humans are truly persons. It is reasonable, therefore, to conclude, biblically and theologically, that our unique status as image bearers of God, who's lives should be protected, begins at the moment we are conceived, whether inside or outside our mother's womb. Our moral obligations, as summed up in The Great Commandment and Golden Rule , to love others as ourselves and to treat them only as we would wish to be treated, would appear to begin with our newly conceived and unborn "neighbors," who are already persons and members of the human family.

"Your hands have made me and fashioned me an intricate unity . . . did you not . . clothe me with skin and flesh, and knit me together with bones and sinews?" "You have formed my inward parts; You have covered me in my mother's womb."

Job 10: 8, 10, 11 and Ps 139:13 


\author{
Handout Ten: Essay: Does all human life \\ possess equal dignity and value, \\ and is all human life worthy \\ of respect and protection?
}

Introduction:

Is there something intrinsically valuable about human life? The human embryo is the same kind of being (i.e. human, of the species Homo sapiens) that we are. So if we conclude that the embryo is not worthy of respect and protection, and thus eligible for research that harms and even kills it, we must come up with some criteria or basis for determining that some human beings are worthy of respect and protection and others are not; in other words, that human life is not, in fact, equal in value. It forces us to the conclusion that some members of the human species have certain characteristics that give them moral worth, and others lack those characteristics. It also forces us to have to determine precisely what those characteristics might be. Enter Peter Singer, Professor of Philosophy and Ethics at Princeton University since 2001. Singer is known for his controversial view that all human life is not of equal value, and even that some humans (like newborns and early infants) are of less moral worth than some fully grown adult animals like pigs, dogs, and chimpanzees. $1 \mathrm{~A}$ staunch advocate of animal rights, Singer teaches that worth and dignity of any species, including human, is on a sliding scale based on whether or not a member of that species has certain characteristics.

It is very important to know that Singer does not deny, like some who seek to justify embryo and fetal destruction (abortion), that human embryos and fetuses are in fact human beings. Singer knows the science, and claims,

I accept ... that the early human embryo is 'human life.' Embryos formed from the sperm and eggs of human beings are certainly human, no matter how early in their development that may be. They are of the species Homo sapiens, and not of any other species. We can tell when they are alive, and when they have died. So long as they are alive they are human life. (Singer 2004, 37)

So what makes the killing of a human embryo, or fetus, not morally problematic for Singer? People operate under what he calls an "unargued assumption that to be a member of the species Homo sapiens, is sufficient to make a being's life precious" (Singer 2004, 39). For Singer, simply being a human is not sufficient in itself for assigning moral worth to humanity. He, as we shall see, argues that it is only the achievement of certain characteristics or capacities that gives a human being moral worth.

What might those characteristics be?

Singer urges us to ask "why. . the life of a member of the species Homo sapiens has greater claim to protection than the life of a member of the species Pan 
troglodytes, the chimpanzee." The long and short of it is that whatever makes human beings distinct from other species are the characteristics that give human life moral worth. Human embryos are being treated like lab rats; should they? Is there a difference between destroying a embryo for its stem cells and killing a mouse for experimental research; or, more to the point, a five year old child for its organs if it benefits many others? Most would agree that this is morally unacceptable, but then not even understand why they would. What makes a five day-old or even five year-old human child more valuable than a five-day old human embryo? Normally we believe that human beings are valuable because they are not like animals in important ways, i.e. because they are humans. We then begin to look for characteristics of distinction. Some, like Singer, have suggested that humans are valuable, and their death is of more moral significance than that of a lab rat, say, because humans have a developed sense of self including a sense of the past and future. If one denies that humans lack intrinsic value simply by virtue of the kind of being that they are (a human being), they have to require an additional attribute or attributes for determining moral worth. This usually is identified as a capacity for certain mental functions that are lacking in members of other species.

Singer, also a major advocate of embryonic stem cell research, argues that humans have certain mental capacities that make it possible for them to "live in ways that, as far as we can tell, cats, dogs, baboons, and even chimpanzees, cannot" (Singer 2004, 41). He continues, "Only human beings have sufficient awareness of the future to plan their lives, with careful deliberation, not for a day or a week, but for years ahead. Only humans can think through their moral choices and be held morally responsible for what they do. This answer ... points to characteristics of human beings that can plausibly be held to have some moral significance" (Singer 2004, 41). He continues, "Our mental capacities, when they are working properly, make our lives markedly different from those of other animals. We share with many other animals the capacity to feel pain, and also to feel emotions like love and fear, but perhaps not ... the capacity to understand that we have a past and a future. Perhaps that capacity to see our own life as extended over time, and therefore to have future-oriented desires, may provide grounds for holding death to be a greater tragedy when it befalls beings like us than when it befalls beings lacking that capacity" (Singer 2004, 41-42). So Singer, a prominent and influential thinker, identifies this "future-oriented desires" as those attributes which distinguish humans from animals.

It is immediately obvious that Singer's criteria make the death of human embryos, which lack these capacities, morally insignificant. He writes, "If human life is more precious than non-human life, it is because humans possess higher mental capacities that nonhuman animals lack. Embryos, however, are utterly lacking in such higher mental capacities Hence if it is the possession of higher mental capacities that marks the line between beings whose lives need to be protected and beings whose lives do not need to be protected, then human embryos-and fetuses, for that matter-fall on the wrong side of the line" (Singer 2004, 42). By this, of course, he means that their death is a non-issue, when a human embryo is killed in a lab experiment it carries no more significance than the death of an amoeba or a mouse. Thus, in Singer's thinking, it is a forgone conclusion that killing them to retrieve their stem cells should be of no moral concern to us. Further, this logic justifies the deliberate generation of cloned embryos for this very purpose. 
This reasoning, however, is problematic for anyone who would oppose the unconditional killing of newborn humans and early human infants because this same criteria of possession of certain mental capacities, particularly "future-oriented desires," makes the death of newborn infants, even early infants up to a couple of months, a non-issue as well. Even Singer, who advocates infanticide, concedes this point. He writes, "Admittedly, the idea that only beings [who possess these capacities] are precious and should be protected has implications that go far beyond the status of early embryos. Newborn human infants don't have those capacities either" (Singer 2004, 42). Singer sidesteps the issue of unconditional infanticide by claiming that most infants are "loved and wanted" by their parents, and this is sufficient enough of a reason to establish legal protections of newborns and infants, even "grounds for making birth the point at which killing the developing human being becomes a crime" (Singer 2004, 42). Singer, elsewhere, however, clearly advocates the killing of infants that are not wanted by their parents, particularly if they are deformed.2

Careful analysis of Singer's argument that moral respect rests on the basis of certain mental capacities, like a sense of one's past and future, however, justifies unconditional infanticide, not just the killing of embryos and fetuses, but severely mentally deficient children and adults as well. The moment you set up any criteria for the moral worth of human life apart from simply "being human" is the moment you make personhood an achievement, and no longer intrinsic. What is glaring, here, is that Singer does not view all human life to have the same value or moral worth. If certain mental functions are the criteria for assigning this worth, then the absence of these capacities do not only exclude the embryo and fetus from this realm of moral respect, but likewise the newborn and early infant. Further, it excludes those who may lose these capacities through injury or illness. So these criteria cannot work for those who feel, including many pro-choice advocates, that most killing of humans (including newborns and infants) is wrong simply by virtue of the kind of being these humans are. 3

Conclusion: What should those characteristics be?

We now come to the conclusion of when a human life deserves respect and legal protection. We know, scientifically, that a distinct, self-organizing and self-directing human individual begins at conception, or when fertilization is complete. We also know that the kind of being this is - a newly generated human being in its embryonic stage-is the same kind of being it will be as a fully mature human adult. It is nothing less than a living human being. While a zygote, embryo, and fetus, we were the same kind of being as we were when a newborn, infant, child, and now adolescents and adults; we were and are nothing other than human beings. There is actually only one valid criterion for establishing substantial moral respect and legal protection toward all humans and that is membership in the species Homo sapiens; membership meaning to be a whole and complete, even if immature, organism of the species. In each subsequent stage of our development, we became more mature than we were in the previous stage, but moral worth must not be based on our level of development or maturity. Just as the newborn and early infant is nothing other than a less mature, but developing, human being in relation to an adult, so is the embryo to an adult in the exact same way. Failure to make the killing of humans morally wrong by virtue of the kind of beings that we are forces us to establish criteria that, when applied consistently, 
leads to the justification of unconditional infanticide, and even other forms of euthanasia. To conclude anything less requires the arbitrary establishment of criteria (like self-consciousness or "future-oriented desires") which quickly opens the gate to these moral evils, with no certain basis for objecting to, or resisting them in society. This is why we must be committed to respecting the dignity and protecting the integrity of human beings at every stage of their development, beginning with the crucial embryonic stage which begins when conception is accomplished.

Dealing with Objections:

Some preliminary answers (The following are this author's attempt to address some of the difficult questions which arise from asserting that the human embryo is a person of moral worth, they are, indeed, "preliminary" and subject to criticism and correction. They are offered here in hopes to stimulate further dialogue on these critical issues.)

1. The belief that embryos are human beings is a theological or religious opinion and you cannot impose that on others as a matter of social policy. I can respect your opinions, but you have to respect mine as well.

We can be unaware of the facts, even as a majority. Ignorance of the facts does not make them non-existent or untrue. We must learn the facts. Religious people may believe something that is scientifically and factually true, although it is not known).

2. The embryo is so small, smaller than the head of pin, even microscopic, how can we consider it to be of such moral worth?

Size is a relative matter. Since when are larger, more developed people of greater moral worth than smaller, less developed ones? Certainly size has nothing to do with moral worth.

3. The embryo has no ears, eyes, legs, heart, etc. how can we call it human?

What does it mean to be "human"? Do we have to have all our parts? It certainly has nothing to do with what parts we do or do not have. Are double amputees human? They don't look like the rest of us completely. What about people born without an eye, or a particular limb or organ? If they lack a part that other humans have, are they still human? Certainly would say they are, in fact, human. The issue is that they possess human

4. Since brain-death is considered true death, how can an early embryo be considered a human being if it has no brain that is active and functioning?

This is confusing death of a body with death of a person. Does physical death totally make us non-existent? We do see a dead body, a corpse, and know that his or her brain has quit functioning, but an embryo is not to be equated with a corpse (false analogy). An embryo is not dead, but very much alive, whether a zygote, or a blastocyst, in the same 
way that a full grown adult is alive with just a greater amount of cells. And as we have already seen, where there is human life, there is also human being. So while the body and brain is dead, and while cannot say for sure what happens to that which made the body alive (Many people believe in an immaterial "soul" or "spirit" but this cannot be scientifically verified), but we do know, scientifically, that the embryo is alive.

5. But embryos cannot think, they are not self-conscious or reasoning beings, they have no sense of their past or their future, they cannot act on their own, but this is what human beings do, so how can embryos be humans?

Although it is safe to say that these are definitely unique characteristics of being human, and characteristics, likewise, that distinguish humans from animals, these are not the only things that distinguish humans from animals, in fact our potential alone so distinguishes us, and that potential resides in the human genome, whether it is manifested or not. Further, this is defining human by its functionality, what humans do, humans do certain things because they are human, and they are not human because they do these things. People with severe brain damage, or in a coma, or with a degenerative disease that affects their brain may not noticeably function as other humans, but this in no way detracts from their being human. This argument, if carried to its logical conclusion, could be used to justify euthanasia, not just killing human embryos.

6. Isn't the embryo just a potential human, like an acorn is a potential oak tree, but not really an oak tree?

First, this is a false analogy. We do not really look at the demise of either an acorn OR a fully grown oak tree as morally significant, but there comes a time when the death of a human being is considered morally significant by just about anyone. So the question becomes one of whether the word "potential" is a safe criterion to use. Does this mean that something that has not reached its full potential is less than human; like an infant or even a toddler or adolescent? Further do any of us ever really "reach our full potential?" How much of our potential do we have to achieve to be considered worthy of respect and protection? "Potential" is too arbitrary of a term to use in this life-death decision concerning living human beings.

7. Since there is such great loss of embryos in nature anyway, why should we care about their loss in the lab, or by anything that we do? We know the loss of human life in nature is great (earthquakes, fires, tsunamis, etc). In fact, more born people die in the world daily than embryos are lost during normal situations.

This does not make it morally acceptable to kill humans because "so many die anyway." The question we should ask is what gives us the prerogative to kill fellow humans? We have already established that embryos are indeed fully alive human individuals; but what, if anything, makes them expendable?

\section{Should Christians not use artificial contraception?}


Christians should at least research this issue instead of following the crowd and using birth control because it is easy or just what others do. A commitment to the dignity and worth of human beings created imago Dei demands that one research this to make sure that they are not doing anything deliberately that can even potentially harm their offspring. The issue at hand is to inquire deeply as to whether or not the hormone or device interferes with implantation of an already existing embryo into the uterine wall.

\section{Should Christians not use artificial reproductive technologies like in vitro fertilization?}

As stated above, Christians must be informed of the potential for degradation of the human embryo (their offspring). Not enough realize the consequences of these technologies. If it is possible to become pregnant without having to generate numerous other embryos which will not or cannot be implanted, then this may not be problematic. A goal of generating only the embryos one tends to implant would be a good rule of thumb here. A corollary to this issue is whether or not young men and women (especially of college age) should donate their gametes for IVF procedures to assist couples having difficulty conceiving.

10. If embryos are so important why don't we grieve over their loss and have funerals for them? Since when does our grieving or not grieving over a particular individual have anything to do with its (his or her) worth?

First, our emotional response to another's plight does not have any impact on their value. The Nazi doctors, no doubt, had little to no emotion when they experimented on the Jews, but this devaluing of the Jews did not diminish their actual value. Further, ignorance may result in a lack of emotional response. German children were taught that the Jews were sub human, and thus it became easier for them to exterminate them. If I do not realize what is being harmed (a human being), I may not have pity or grief over its demise, but if I learn what it really is, I will have a different (appropriate) emotional reaction. And with all that said, some people do have funerals for their miscarried and still born offspring precisely because they do recognize this as a death in the family.

\section{Human embryos cannot feel anything, like pain, so they cannot suffer. How could} harming them be wrong?

The idea that the feeling of pain as the basis of whether or not a human being (which we have established that the human embryo is) should be experimented upon is inadequate. After all, if we suppose that the Nazi doctors had anesthetized their Jewish subjects before experimenting upon them (which they did not, of course) we would not thereby conclude that since the Jews did not feel pain during the experiment, the experiment was thereby morally justified. What made the Nazi experiments immoral was that they were being performed on human beings, period. 
12. Since cloned human embryos were made without regular fertilization, are clones really human beings?

As discussed above, human clones are nothing less, or more, than a later conceived identical twin. No one would argue that a twin, because it is a twin, is any less human than the being from which it generated.

13. Doesn't the possibility of twinning make it incorrect to call an early embryo a distinct and unique individual?

Twins are still individuals. Although they share a genome in every respect, they are still separate entities, and will, as they develop, take on unique characteristics.

Before the twinning occurred there was only one individual, after the twinning occurred there were two individuals.

14. Don't we have a moral obligation to do all we can in scientific research to help alleviate human suffering?

The short answer is yes, we do. In fact, a commitment to a sanctity of human life ethic definitely entails being aggressive about alleviating human need and suffering. But it also requires that we do not do so at the expense of other human beings. If human embryos are, as we have argued, 100\% living human individuals, then these individuals have a right to life, whether present laws acknowledge this or not, and we cannot be sacrificing them, or, worse, generating more embryonic humans (clones), just to destroy them for the sake of other peoples being healed. (cf. the movie The Island) 


\section{Handout Eleven: Nine Reasons Why Abortions \\ Are Legal (by Planned Parenthood)}

The following article has been copied, as it appears, on the Planned Parenthood webpage.

Abortion is never an easy decision, but women have been making that choice for thousands of years, for many good reasons. Whenever a society has sought to outlaw abortions, it has only driven them into back alleys where they became dangerous, expensive, and humiliating. Amazingly, this was the case in the United States until 1973, when abortion was legalized nationwide. Thousands of American women died.

Thousands more were maimed. For this reason and others, women and men fought for and achieved women's legal right to make their own decisions about abortion.

However, there are people in our society who still won't accept this. Some argue that even survivors of rape or incest should be forced to continue their pregnancies. And now, having failed to convince the public or the lawmakers, certain of these people have become violent extremists, engaging in a campaign of intimidation and terror aimed at women seeking abortions and health professionals who work at reproductive health clinics.

Some say these acts will stop abortions, but that is ridiculous. When the smoke clears, the same urgent reasons will exist for safe, legal abortions as have always existed. No nation committed to individual liberty could seriously consider returning to the days of back-alley abortions - to the revolting specter of a government forcing women to bear children against their will. Still, amid such attacks, it is worthwhile to repeat a few of the reasons why our society trusts each woman to make the abortion decision herself.

\section{Laws against abortion kill women.}

To prohibit abortions does not stop them. When women feel it is absolutely necessary, they will choose to have abortions, even in secret, without medical care, in dangerous circumstances. In the two decades before abortion was legal in the U.S., it's been estimated that nearly a million women per year sought out illegal abortions. Thousands died. Tens of thousands were mutilated. All were forced to behave as if they were criminals.

\section{Legal abortions protect women's health.}

Legal abortion not only protects women's lives, it also protects their health. For tens of thousands of women with heart disease, kidney disease, severe hypertension, sickle-cell anemia and severe diabetes, and other illnesses that can be life-threatening, the availability of legal abortion has helped avert serious medical complications that could have resulted from childbirth. Before legal abortion, such women's choices were limited to dangerous illegal abortion or dangerous childbirth.

3. A woman is more than a fetus. 
Some people argue these days that a fetus is a "person" that is "indistinguishable from the rest of us" and that it deserves rights equal to women's. On this question there is a tremendous spectrum of religious, philosophical, scientific, and medical opinion. It's been argued for centuries. Fortunately, our society has recognized that each woman must be able to make this decision, based on her own conscience. To impose a law defining a fetus as a "person," granting it rights equal to or superior to a woman's — a thinking, feeling, conscious human being — is arrogant and absurd. It only serves to diminish women.

\section{Being a mother is just one option for women.}

Many hard battles have been fought to win political and economic equality for women. These gains will not be worth much if reproductive choice is denied. To be able to choose a safe, legal abortion makes many other options possible. Otherwise an accident or a rape can end a woman's economic and personal freedom.

\section{Outlawing abortion is discriminatory.}

Anti-abortion laws discriminate against low-income women, who are driven to dangerous self-induced or back-alley abortions. That is all they can afford. But the rich can travel wherever necessary to obtain a safe abortion.

\section{Compulsory pregnancy laws are incompatible with a free society.}

If there is any matter that is personal and private, then pregnancy is it. There can be no more extreme invasion of privacy than requiring a woman to carry an unwanted pregnancy to term. If government is permitted to compel a woman to bear a child, where will government stop? The concept is morally repugnant. It violates traditional American ideas of individual rights and freedoms.

\section{Outlaw abortion, and more children will bear children.}

Forty percent of 14-year-old girls will become pregnant before they turn 20. This could happen to your daughter or someone else close to you. Here are the critical questions: Should the penalty for lack of knowledge or even for a moment's carelessness be enforced pregnancy and child rearing? Or dangerous illegal abortion? Should we consign a teenager to a life sentence of joblessness, hopelessness, and dependency?

\section{8. "Every child a wanted child."}

If women are forced to carry unwanted pregnancies to term, the result is unwanted children. Everyone knows they are among society's most tragic cases, often uncared-for, unloved, brutalized, and abandoned. When they grow up, these children are often seriously disadvantaged, and sometimes inclined toward brutal behavior to others. This is not good for children, for families, or for the country. Children need love and families who want and will care for them.

\section{Choice is good for families.}

Even when precautions are taken, accidents can and do happen. For some families, this is not a problem. But for others, such an event can be catastrophic. An unintended pregnancy can 
increase tensions, disrupt stability, and push people below the line of economic survival. Family planning is the answer. All options must be open.

At the most basic level, the abortion issue is not really about abortion. It is about the value of women in society. Should women make their own decisions about family, career, and how to live their lives? Or should government do that for them? Do women have the option of deciding when or whether to have children? Or is that a government decision?

The anti-abortion leaders really have a larger purpose. They oppose most ideas and programs that can help women achieve equality and freedom. They also oppose programs that protect the health and well-being of women and their children.

Anti-abortion leaders claim to act "in defense of life." If so, why have they worked to destroy programs that serve life, including prenatal care and nutrition programs for dependent pregnant women? Is this respect for life?

Anti-abortion leaders also say they are trying to save children, but they have fought against health and nutrition programs for children once they are born. The anti-abortion groups seem to believe life begins at conception, but it ends at birth. Is this respect for life?

Then there are programs that diminish the number of unwanted pregnancies before they occur: family planning counseling, sex education, and contraception for those who wish it. Anti-abortion leaders oppose those, too. And clinics providing such services have been bombed. Is this respect for life?

Such stances reveal the ultimate cynicism of the compulsory pregnancy movement. "Life" is not what they're fighting for. What they want is a return to the days when a woman had few choices in controlling her future. They think that the abortion option gives too much freedom. That even contraception is too liberating. That women cannot be trusted to make their own decisions.

Americans today don't accept that. Women can now select their own paths in society, including when and whether to have children. Family planning, contraception, and, if need be, legal abortion are critical to sustaining women's freedom. There is no going back.

Published: 01.02.04 I Updated: 09.22.06

Published by the Katharine Dexter McCormick Library

C1985 Planned Parenthood ${ }^{\circledR}$ Federation of America, Inc.

All rights reserved. 


\section{Handout Twelve: Good and Bad Faith in the Abortion Debate}

Introduction:

It is easiest to understand these opposites by defining "bad faith" and then understanding that "good faith" is just the opposite.

Bad faith is failure to consider the problems one's own viewpoint raises. It is selective perception in the sense of not considering or addressing the problems, inconsistencies etc. with one's own viewpoint and not acknowledging the valid points of the arguments of those in opposition. It is ignoring the tensions and worse, doing it purposely. With regard to the Bible, it is interpreting the text to say more than it really does.

I. "Bad faith" on both sides.

Before reading the following quotes, discuss - in what ways have both sides of the abortion debate been guilty of "bad faith?"

A. Says pro-choice doctor Tim Johnson (also claiming to be a Christian):

There is no question that an abortion terminates a developing life. I use the word "developing" to indicate the distinction between a life not yet capable of existence outside the womb and one that is. And while both types of life are of value, I am one who believes that we should be more concerned about life after birth. I also believe that in a less than perfect world we are forced to make choices among less-thanperfect alternatives. And I believe there are situations in which it is morally appropriate to choose abortion rather than bring in to full existence a life condemned to pain and suffering and rejection ... the focus on conception and life in the womb seems to blind so many anti-abortionists to the "slow dying" of so many of the already living in our world: the starving children and adults in so many countries, the innocent victims of war, the poor in our own urban neighborhoods. (Koop and Johnson 1995, 25, 26)

B. Says pro-life former Sec. of Health and Human Services for Virginia Kay Coles James:

The "pro-choice" movement has had much success in tacking on the abortion platform to an existing platform of women's rights and women's freedom . . . we need to refocus the debate on life. Choice is about thirty-one flavors of ice cream and dozen different TV and VCR selections; 'choice' is not about who lives and who dies. Let's keep the focus there. To do that, we need to change our culture and our attitudes. If we do, we will not only recapture all of the ground we have lost, but we will also move forward to a time when human life is again respected for the beautiful 
creation that it is - life that should be greeted with love and admiration. (James 1995, 106-107)

II. Three areas of "bad faith" both sides have to consider.

\section{A. The moral status and claims of the newly conceived and unborn}

The advocates of abortion rights are unlikely to treat a miscarriage as the same sort of a loss as an appendectomy, and those who would prohibit abortion are unlikely to check the menstrual flow each month to see if there's been a death in the family. (Verhey 2003, 195)

\section{B. The needs and claims of the woman}

The pro-life position has, traditionally, been "unfriendly to the aspirations of women for social equality with men" and especially "inattentive to the tragic character of the choices some women have" including the "cultural assumptions" that " rearing children falls to frequently on the mother alone." As for the pro-choice side, there has been largely an ignoring of the "complex relationship between a woman and the new life within her, the mutuality of mother and fetus. (Verhey 2003, 195-6)

\section{The value of human life}

Those opposed to abortion seem to sometimes assign an absolute value to human life, a valuation that is inconsistent with other positions they may take on capital punishment and war and with positions they may fail to take on famine relief and health care. Those who defend abortion rights, on the other side, seem sometimes to assign to human life so negligible a value that the response to human life is insignificant. (Verhey 2003, 196)

III. Do we use the Bible in "bad faith?" (Discuss this first)

A. The Silence of Scripture

Why is a prohibition of abortion not an explicit part of the Story God tells? Abortion was not an unknown then, and it is not a new dilemma as a result of modern day technologies.

1. Prohibition of Abortion in Non-Christian writings

a) In the Assyrian law code of Tiglath Pileser (mentioned in the Bible; 2 Kings 15:29 1114-1074 BC) induced abortion was a capital crime.

b) In the Hippocratic Oath $\left(4^{\text {th }}\right.$ cent. $\left.\mathrm{BC}\right)$ abortion was prohibited to doctors.

c) Josephus in Against Apion ( $1^{\text {st }}$ cent. $\left.\mathrm{AD}\right)$ wrote, "The law has commanded to 
raise all children and prohibited women from aborting or destroying seed."

2. Two options for explaining the silence of Scripture.

a) "A becoming reticence to judge too quickly concerning the morality of another's choice" (Simmons, 1996)?

b) "Abortion was so unthinkable to an Israelite woman that there was no need even to mention it in the criminal code" (Anderson 2005, 38-39).

\section{Later Christian prohibitions of abortion}

It is important to point out that "the silence of Scripture did not prevent the early church form strong words in condemnation of induced abortion" (Verhey 2003, 198).

a) Didache - "Do not murder a child by abortion or kill a newborn infant."

b) Epistle of Barnabas - "You shall not slay a child by abortion. You shall not kill that which has already been generated."

c) Athenagoras (in a letter to Emperor Marcus Aurelius) - "We say that women who induce abortions are murderers ... the fetus in the womb is a living being and therefore the object of God's care."

d) Clement of Alexandria - "Those who use abortifacient medicines to hide their fornication cause ... the outright murder of the fetus."

e) Tertullian - "We may not destroy even the fetus in the womb."

Why do you suppose the later church Fathers saw abortion as so heinous, but it is not addressed as such in the Bible itself?

\section{B. The Strangeness of Scripture}

How could the following texts be used in "bad faith" by pro-life and/or pro-choice advocates in terms of status of the fetus, needs of the woman and the value of human life? Genesis 2:7, 3:16, Exodus 20:13 (cf. with Deut. 3:1-3), 21:22-25, Psalm 139:13-16, 1 Timothy 2:11-15

Do you agree/disagree with Verhey's conclusion that:

We should be suspicious of arguments that move from [these texts] to [absolute] claims about how we should regard the status of the unborn [women and valuation of life] today and about how we should regard the fetus [for either pro-choice or pro- 
life purposes]. We do better to . . admit the ambiguities and uncertainties of interpretations. (Verhey 2003, 200)

What would this mean for us in the debate? 


\title{
APPENDIX 6
}

\section{FOUR SERMONS ON BIOETHICS AND BIOETHICAL ISSUES}

\author{
Sermon One: Carried all the Way: \\ Godly decision-making at the beginning and ending of life.
}

13 January 2008 a.m. Service

Introduction:

This January $22^{\text {nd }}$ marks the $35^{\text {th }}$ anniversary of the Roe v. Wade decision. The consequences of that decision have been the death of over 48 million unborn lives. This averages to nearly 1.4 million abortions performed annually in our country alone. The legalization of abortion on demand has opened the gates to mentalities and methodologies that detract from the dignity and worth of all human life.

The late Francis A. Schaeffer prophetically spoke in his Whatever Happened to the Human Race, "Will a society which has assumed the right to kill infants in the womb . .. have difficulty in assuming the right to kill other human beings?"

The quick answer is "no," and we have seen an onslaught of killing for convenience of fetal and embryonic humans for the sake of a "greater good" as well as the contemplation of providing euthanasia "services" for the comatose, and elderly.

Opposite of this mentality we find God's word which clearly upholds the value and preciousness of human life.

I want to talk to you about bioethics, and share three points relevant to us as Christians.

\section{A Biblical Context for Bioethics}

A. Explaining the Text:

Of all the texts I could use to discuss bioethics, I have chosen Isaiah 46:3-4. This may not be as familiar as others, but its relevance should soon become apparent. I am using it not only for our discussion today, but as a theme for this entire four-part series. Carried All the Way: Godly decision-making at the beginning and ending of life.

Listen to me, ... you whom I have upheld since you were conceived and carried since your birth; even to your old age and gray hairs, I am He. I have made you and I will carry you. I will sustain you and I will deliver you. 
Isaiah's first audience was Israel. This passage is a contrast between the idols that humans make and carry and the God who makes and carries humans. The logic of Isaiah's argument is essentially that it is foolish and wrong to trust in the gods one has crafted and carried rather than the God who created and carries you. I believe this applies not only to a nation, but to individuals as well, and this has great significance for bioethics.

Let me explain:

Interestingly, the Lord places this communication of His care for His people into the language of the lifespan of an individual human; from conception to old age, and by implication death. This human lifespan serves as the basis for His assurance to His people, Israel, and, through Messiah, all people, that He will carry them from beginning to end. So we will look at this as a profound truth concerning the individual that the Lord carries us all the way, from the moment of our conception to our last dying day; from the womb to the tomb.

To take us through this continuum we will consider 12 assertions the Lord makes about Himself and His relationship to the human lifespan.

1. "Listen to me ..."

This is a call to carefully consider His words. Don't just hear, but take to heart. For God to tell us to "listen" tells us that he takes a personal interest in His people, He is not a distant deity having no more to do with those whom He has created. He communicates, He calls, He is concerned with what we do; this distinguishes the God of the Bible from the deities of pagan religions.

2. "You whom I have upheld ..."

This word, "upheld" means literally "to carry or hold up a burden or load." It is the same word used in verse 2 to contrast how the idols (gods) that humans make must be carried by them and are burdens. Here, however, the Lord tells His people that He carries them and is no burden to them, but assumes them as His burden.

3. "Since you were conceived ..."

Literally, this means "from the womb" and indicates the actual anatomical place in a woman where conception and prenatal development occurs until the time of birth."

4. "And have carried ..."

This term, which means, literally, to "to take up and carry," implies care, or desire for the object lifted. 
5. "Since your birth ..."

This is a parallel term to the idea of conception, and means, from the womb, but is a synonym of the first word, and indicates a place of protection for the vulnerable and weak. It is actually a metaphor from a verb emphasizing care, compassion and concern, shown esp. by the powerful to the vulnerable.

6. "Even to your old age and gray hairs ...

While old age is quite literal, the idea of "gray hairs, has a metaphorical sense of "to the last, or the "very end" of the course implying death.

7. "I am He, ..."

Yahweh regularly identifies Himself in this unique way. He is the only God of Israel, namely, because He is the only God, period! By this the LORD is implying, "I am your sufficiency, all you need. I am the God in whom you are complete, and by virtue of this, I am your sole authority. Thus, you should look nowhere else." The "I" here is emphatic in verse 4 , being repeated five times.

\section{8. "I will carry you ..."}

This word is a synonym for the term in v. 3 but has a different sense; it actually draws attention to redemption, as we shall see shortly.

10. "I have made you ..."

This term actually draws attention to the reality that Yahweh is our origin; the fact that we were made by Him. The first use of this term in relation to man is found in Gen 1:26 where God intends to "make" man in "our image and after our likeness." The word is also used in Psalm 139:16 affirming that individuals have been "made in secret" in our mother's womb (Ps 139:15). God takes responsibility for the work of His hands. He, unlike the gods of the pagans has created us and will carry us.

\section{1. "And I will lift you up. I will carry you. .."}

This is the same word used earlier in verse 3 which means "to take up and carry" continuously out of care or desire for the object lifted, but here, coupled with the word for "carry" it takes on a special, redemptive, significance. These two synonyms for "carry" are found right next to each other in a coming passage in Isaiah as well. Isaiah 53:4 says that Messiah "lifted up our sicknesses, and carried the heavy burden of our sorrows." Messiah takes upon Himself our sicknesses, our sorrows, and in v. 11 our sins. "My righteous servant shall justify many, for He shall bear [the heavy burden of] their iniquities." There is no other God in the history of the planet that has done this! The rhetorical question of v.5 implies as much, and v. 9 makes the statement clear; there is no god like our God! This is the most 
significant way in which the Lord fulfills His character as the God who carries us. He carries us, He labors under the heavy burden of our sickness, sorrow and sin . . . and as Christians, looking back at the cross, we have a deeper understanding of the significance of this.

\section{2. "And deliver you."}

In clear and deliberate contrast to the idols that could not deliver the burden in v.2. God is the God who carries His people, Israel and, through Messiah, the Gentiles who turn to Him, all the way.

This passage tells us that God's caring and compassionate concern moves Him to act in our personal history from the time we begin in the womb, and extends to the end of our days. His power and love are demonstrated in our creation and redemption; a redemption that requires Him to stoop so low and to make us His burden . . . an image that takes us right to the cross of Jesus, laboring under the burden of our sin to redeem us.

In the Christian story God ... comes down; down from the heights of absolute being into time and space, down into humanity; down further still, to the womb; down to the very roots of humanity and seabed of the Nature He has created. But He goes down to come up again and bring the whole ruined world up with Him. One has the picture of a strong man stooping lower and lower to get himself under some great complicated burden He must stoop in order to lift, he must almost disappear under the load before he incredibly straightens his back and marches off with the whole mass swaying on his shoulders. C.S. Lewis, Miracles

B. Applying the Text:

Here we must ask ourselves, What is the application? What has any of this to do with bioethics?

1. First, ethics is the discipline that seeks to understand how we humans should act, to establish standards for our behavior.

2. Bioethics, then, has to do with how we behave in matters of life and death issues.

The following quote from James C. Childs has tremendous ethical implications and points us in the right direction as we consider our (bio)ethical lives.

To know the love of God and trust in it is to become a people of love. To know the mercy of God is to become a people who are merciful. To know the creator God who cares for the earth and everything that is in it is to become a people who are good stewards of that creation. To know God in Jesus Christ as the one who gave himself up for all people is to be a people ready to receive and affirm the worth of all people, even our enemies. To know God in Jesus as the creator and redeemer of all life is to be a people who uphold the value of life. In these and many other ways we ... 
become a people whose choices in life for the right and good are a reenactment of God's action in our life. (Childs 1992, 6)

Consequently, to be a people who knows the God who carries us from conception to death is to be a people who esteem human life from its beginning in the womb to its very end with the highest value. This divine model will have significant influence on how we make ethical choices about life and death.

\section{The Urgency of the Contemporary Bioethical Challenge}

A. I need to share with you a few quotes that have shaped my research and fueled my passion for this subject.

1. The first is from Martin Luther, the great Reformer:

If I profess with the loudest voice and clearest exposition every portion of the truth of God except precisely that little point which the world and the devil are at the moment attacking, I am not confessing Christ, ... where the battle rages there the loyalty of the soldier is proved.

\section{The second is from Christian bioethicist Nigel Cameron:}

The church has a prime responsibility to prepare its people to live 'in' the world according to principles that come from God. It is remarkable, for instance, that so many Christians seeking help in having a child fail to grasp the moral significance, for example, of reproductive technology, and find themselves led through referrals into using in vitro fertilization or surrogacy or some other questionable ... new technology - - with no context for their decisions set in Christian education within the local church. It is hard to see how any church could avoid addressing the bioethics agenda in Sunday school and pulpit teaching, youth ministry, wedding preparation, young married's groups - - indeed, throughout its educational task.

3. The third is from a secularist and blatant anti-Christian, Peter Singer Professor of Bioethics at Princeton University. In $2005 \mathrm{He}$, wrote a piece entitled, The Sanctity of Life, Here Today, Gone Tomorrow." His statement speaks for itself.

During the next 35 years the traditional view of the sanctity of human life will collapse under pressure from scientific, technological, and demographic developments. By 2040, it may be that only a rump of hard-core, know-nothing religious fundamentalists will defend the view that every human life, from conception to death, is sacrosanct.

It seems quite clear from these last two quotes, one from a Christian and the other from an atheistic perspective, that indeed the "battle rages" to use Luther's words, in the 
arena of bioethics. Put simply it is in this arena that we as individual believers as well as the church together, will have our loyalty, as Christ's soldiers, proved.

Luther's call is to all ages to focus on those points of biblical theology and ethics that are undergoing the clearest secular and satanic attack. We can see from Singer's quote where that attack lay, against the very idea of the sanctity of life, and Cameron gives us a concrete framework for acting to equip God's people to rise to the challenge as His soldiers.

B. Now allow me to define some key terminology for you.

1. First we need to understand "bioethics" more fully.

You might think this term is irrelevant to you; something for discussion by people with PhDs in ivory towers of education, but definitely not me, the average Jack or Jill in the pew. Like it or not, acknowledge it or not, we are living in the age of biotechnology, which refers, in large part, to all the ways that biological sciences are applied to heal, help and even enhance human life. Bioethics involves reflection on the moral implications of biotechnology to determine how it should and should not be applied.

\section{Our second term is biotechnology or biotech.}

Biotechnology is confronting the culture and church with some of the greatest ethical challenges we have ever faced as humans. This is largely the case because its most important object is us! Issues involving artificial birth control, assisted reproduction, genetic screening and engineering, embryonic cloning and stem-cell research, abortion, and end-oflife dilemmas are just some of the major bioethical issues looming large in cultures throughout the world. Through biotechnology we are looking at a possible future in which human embryos are generated (farmed) in labs solely for experimentation, euthanasia is nearly as commonplace as abortion, parents will have the option to select detailed genetic features of their offspring prior to their conception, and baby-making will not be customarily done in the bed but the lab!

C. S. Lewis prophetically argued in his classic Abolition of Man, that once a society abandons the idea of objective truth, it naturally and inevitably follows that morality and then the very notion of humanity will fall. That is, the abolition of objective moral truth gives rise to the abolition of man. Following this, the elite few possessing great power in biotechnology who have thrown out the traditional moral boundaries, will not hesitate to refashion the masses according to their own humanistic wish.

With regard to these and other concerns, cultural experts, not necessarily writing from a Christian perspective, warn that we may already be well on our way to such a future. "The most significant threat posed by contemporary biotechnology," according to futurist Francis Fukuyama, a member of the President's Council on Bioethics, "is the possibility that it will alter human nature and thereby move us into a 'post-human' stage of history."

"In bioethics ... the dignity of the human being is constantly open to redefinition." (Cameron, Daniels and White, Bioengagement, 2000, xii-xiii) 
Such redefinition is graphically illustrated by Robert Haynes, president of the 16th International Congress of Genetics, who said,

For three thousand years at least, a majority of people have considered that human beings were special . . . it's the Judeo-Christian view of man. What the ability to manipulate genes should indicate to people is the very deep extent to which we are biological machines. The traditional view is built on the foundation that life is sacred. ...Well, not anymore. It's no longer possible to live by the idea that there is something special, unique, even sacred about living organisms. (1993)

And don't forget Singer's prediction that, "the traditional view of the sanctity of human life will collapse . . . by 2040," and "only a rump of hard-core, know-nothing religious fundamentalists will defend" it (2005)

III. Bioethics and the Responsibility of the Church

If anyone should be, concerned about this redefinition of humanity, it is the evangelical church. Why? because to be evangelical, or more precisely biblical, means to hold that view of the sanctity of human life dismissed and ridiculed by Haynes and Singer. In short, the biblical proposition that humanity is created in the imago Dei or image of God, and valued and carried all the way by Him from the womb to the tomb, as we have seen, should in itself produce a sense of obligation to engage in bioethics.

While the challenges of biotechnology should especially serve as a motivation for the church's deliberate awareness and action, such does not seem to be the case. According to Cameron, "bioethics and its myriad questions come low on any list of priority concerns" in the local church $(2000,76)$. Sadly, silence is the legacy of the church when it comes to bioethical issues, particularly outside abortion. But there are so many other issues that threaten to undermine the very essence of what it means to be human.

This silence of the church was especially seen in the late 1960s and early 1970s when Roe v. Wade was being decided. Hopefully, the church will not sleep through the latest bioethical issues, the one's confronting us at this moment.

This silence of the church has serious consequences for both Christ's body and the culture. We cripple the body, and we contribute to the continued corruption of culture.

As we move along in the twenty-first century the reality of biotechnology will present ethical issues which evangelicals are or will be facing, and "Because medical ethics is about moments in every human life [from its beginning to its ending], and because God is the author of every human life, there should be great concern in the church about . . bioethics" (Mitchell 1995, 124). Consequently, "Christians can no longer pretend, as it appears they may have in the past, that these dilemmas do not have implications for every believer" (Mitchell 1995, 135). As God's people continue to lack insights informed by God's word concerning the bioethical issues they will inevitably face, "at best they will continue to capitulate to so-called 'experts' all the while intuitively feeling that something is not quite right about the direction they are leading us" (Mitchell 1995, 132). 
Mitchell sees the church as "God's primary instrument for the care of his people" with "responsibilities to itself, as a community, and to individual Christians who comprise the body of Christ" (1995, 124-125). Yet, he says, "Grievously, most churches have neglected the aspects of its 'internal' ministry which best prepare it to . . . address the dilemmas that [will] arise in ... bioethics"

As to the impact of our silence on the culture, the longer biotechnology advances without a Christian vision and voice informing it; it will by default develop under a secular framework. Ironically, the church can actually contribute to the secularization of bioethics (Cameron 2000). When the church fails to articulate bioethical issues from the perspective of a distinctively biblical worldview the secular framing wins the day. As this happens not only will society consider the church more obsolete than it already has, but the very dignity of human life will be at great risk, and "Worse, we [the church] will be aiding in the assault on human life" (Mitchell 1995, 132)!

The silence of the Christ's body cripples itself, and contributes to the continued corruption of the culture where God has placed it to be a preserving force and prophetic voice as salt and light.

The fact that biotechnology is facing humanity with radical, unavoidable and not necessarily desirable, change in this world gives this bioethical educational task in the church great urgency.

\section{Conclusion:}

This is why I am doing what I am doing, and I am sure this is why Pastor Kroll is allowing me to address you on these matters. Our commitment to engage the bioethical challenges of the day derives from our belief in a God who, as we began with, creates us in His image, cares for and carries us through the life span, from womb to tomb, and we, as His image bearers, should do the same. I can find no better summary of all we have been talking about this morning than Francis Schaeffer's observation in his video series and book, Whatever Happened to the Human Race?, of our ethical duties in light of the God to whom we belong.

The Bible tells me who I am and who other people are ... I do not need to be confused, as modern man, .. . People have unique value . . Each human being from conception in the womb until the last gasping breath of old age is in the likeness of God. All men and women, and all children, have great value. They have great value not for some ulterior motive such as sexuality, self-gratification, wealth or power, the good of society or maintaining the gene pool, but simply because of their origin. 


\section{Sermon Two: Baby Making in the Not too Distant Future}

13 January 2008 p.m. Service

Opening Drama: "Blindsided by Science” by Willie E. Honeycutt (Based on Scene from Gattaca. 1997, Directed by Andrew Niccol).

Setting: Ben and Carla Levert enter the Office of Genetic Counseling. At a desk, a geneticist (doctor in a lab coat) stares into a high-powered microscope. Four magnified clusters of cells - eight cells on each cluster - appear on the overhead screen.

GENETICIST: (swings around in her chair to greet her clients, she stands and shakes hands, greetings are exchanged and she proceeds by drawing their attention to the screen.) Your extracted eggs, Carla, have been fertilized with Ben's sperm and, after genetic screening of the resulting pre-embryos, we're left, as you see, with two healthy boys and two very healthy girls. Naturally, no critical pre-dispositions to any of the major inheritable diseases, all that remains is to select the best candidate.

Ben and Carla exchange a nervous smile.

GENETICIST: First, we may as well decide on gender. Have you given it any thought?

CARLA: We really would like to start our family with a boy, you know . . . an older brother.

BEN: A first born son!

GENETICIST: (Smiling and nodding) Most people do, and happily our technology helps us fulfill that wish. It's no longer left to chance, or God, (looking up)

BEN: Uh, what? ...

GENETICIST: (getting back to point) Now, then, you have also specified blue eyes, and dark hair. I have taken the liberty of eradicating any potentially prejudicial conditions as well as premature baldness, myopia, alcoholism and addictive susceptibility, inclination to violence, obesity ...

CARLA: (interrupting, anxious) --We didn't want--diseases, yes, but . . .

BEN: (more diplomatic) See, we were wondering if we should leave some things to God; we are Christians, and ... 
GENETICIST: (interrupting, but reassuring) You want to give your child the best possible start.

Ben and Carla nod and exchange glance.

GENETICIST: Believe me, we have enough imperfection built-in already. Your child doesn't need any additional burdens. And keep in mind, this child is still you, simply the best of you. You could conceive naturally a thousand times and never get such a result.

BEN: (squeezing Carla's hand) She's right, Carla. Yeah (trying to reassure himself).

GENETICIST: It would seem, too, that God would welcome this. After all, didn't He give us the minds to develop this wonderful technology in the first place?

CARLA: (only half-convinced) I guess that makes sense . . .

GENETICIST: (scanning the data on the screen) OK, well, have I forgotten anything?

BEN: I don't think so, doctor.

GENETICIST: (covering herself) Oh, I have to caution you it's not 100\% fool-proof. With multi-gene traits as you requested there can be no guarantees. But we can assure you of the gender, you will definitely have a son.

(Ben and Carla exchange glance and smile)

GENETICIST: But beyond that ... (chuckling slightly) well, even we have to acknowledge our limits.

Carla is staring at the four magnified embryos on the screen.

CARLA: (with deep concern on her face) What will happen to the other three, and what did you do with the ones you screened out?

GENETICIST: (reassuring) The ones screened out have been discarded, they were defective, not meeting your specifications, and these, well . . Carla, they are not babies, merely potential humans, not actual humans. You need not worry about them.

Removing the Petri-dish from beneath the lens of the microscope, he points out the four minuscule specks.

GENETICIST: Look, they are smaller than a grain of sand.

CARLA: But ... 
GENETICIST: They have no brain, no heart; no sense of a past or a future. Whether these bundles of cells have a chance to become humans or not, are fully your choice, but right now, they are not people, I assure you. (sounding a bit confused) This has been the way of conception for decades, and you already made your decision, I don't understand why you are questioning it now.

BEN: I don't know, there's just something about us having so much power . . . (searching for words)

CARLA: (finishing the thought) ... our own children! Deciding which ones live and which ones die.

GENETICIST: (interrupting, leaning forward intently) Mr. and Mrs. Levert, this debate was settled long ago when our country decided in an ancient Supreme Court decision called Roe v. Wade that the human embryo, and even fetus, is not a person under the Constitution. Even many Christians, like yourselves, have finally come to agree with that, I'm sure you know some.

Ben and Carla look at each other and agree with a nod that they do.

GENETICIST: That decision was almost overturned, but the good people and politicians of this country saw reason, and thankfully, we are way past that issue. When we become parents and what our children will be like is more in our control now than ever through genetic science. Incidentally, these advances would never have been possible if that decision was overturned. We really need not re-open obsolete ethical debates about when life begins.

BEN: But doctor ...

GENETICIST: Ben, history shows us that asking these questions simply impede medical progress. Until we got the right person in the Whitehouse, life-giving embryonic cloning and stem cell research was prohibited; but no longer, now the sky is the limit, we can make our future what we want it to be. Politicians have quit getting in the way, and released the funding that allows us to make true progress in science and medicine. If our lawmakers are not getting in our way anymore, neither should our conscience.

CARLA: But doctor ...

GENETICIST: Yes?

CARLA: How can you be so sure about when life begins?

GENETICIST: (with full confidence) Well ... 
Introduction:

Well ... Did you get all that? (Reference to the Drama) In that last five minutes, there was a lot to take in, wasn't there? Well, I figured that the best thing to do tonight is to unpack that thing and consider its implications for our lives and our bioethical decision-making at the beginning of life. It raises so many relevant issues of which Christians must be aware.

But first, with all the new technology regarding infertility and its treatment, I thought I would begin with a story about a 65-year-old woman who, recently and through modern technology, was enabled to give birth to a baby! When she was discharged from the hospital and went home, her relatives came to visit.

May we see the new baby?" one asked.

"Not yet," said the mother "I'll make coffee and we can visit for awhile first."

Thirty minutes had passed, and another relative asked, "May we see the new baby now?"

"No, not yet," said the mother.

After another few minutes had elapsed, they asked again, "May we see the new baby now?"

"No, not yet," replied the mother.

Growing very impatient, they asked, "Well, when can we see the baby?"

"WHEN HE CRIES!" she told them.

"WHEN HE CRIES?" they asked. "Well, why do we have to wait until he cries?"

"BECAUSE I FORGOT WHERE I PUT HIM ... OKAY?!!!"

Moral of this story: Along with improving the ability of the elderly to conceive, technology had better keep up with improving their memory as well!

But let's now return to our more serious story tonight, the one about Ben and Carla Levert and their being blindsided by science. The title represents the reality that many Christian couples have faced and have yet to face in the future. Our technology is getting away from us. Our science is making possible many options that our ethical reflection cannot seem to keep up with, resulting in the scenario we just witnessed. I hope to make tonight's message extremely practical in light of present and soon to be available technologies that have been made possible. I want to give you some principles that can help you and your family guide yourselves as cautious Christians through the land mines of current biotechnologies. I want to give you practical application for how we, as Christians, should use the technologies that take baby-making to a whole new level. In hopes of keeping you and your family from being blind-sided by science and finding yourselves in the middle of such difficult dilemmas as the Levert's did in our drama. 
I. Revisiting Roe v. Wade and basic bioethics

A. First, let's start at the end when the doctor was talking about Roe v. Wade.

This issue puts us in pretty familiar bioethical territory. This is basic bioethical responsibility. We should never come to the place in our country where Roe $v$. Wade is something we get "way past" as the geneticist said. We should never stop talking about abortion because of our commitment to the biblical concept of the sanctity of human life. As long as human beings are killed for convenience in the womb we must not keep silent.

That is why we have asked the Blue Ridge Pregnancy Center and the Liberty Godparent Home to come tonight. These are places to get involved if you have a passion for protecting unborn life. We encourage you to visit their booths following the service. On this matter, we must never stop beating the drum against abortion. We must never, as long as we draw the breath that our God gives us, give up defending the life of the unborn, and providing services and support for women with unplanned pregnancies.

We should also realize that this is the watershed issue that opened the floodgates for the multitudes of reproductive technology challenges we face today, many of which we will consider tonight.

B. Second, let's revisit the issue of when life begins.

The doctor said that we must not let such "obsolete ethical debates" impede medical progress. I just want to say, yes we must! We must continue to affirm that human life, each individual human life, begins at the moment of conception. If we are going to be faithful to the God who "caries us all the way," beginning from conception, as we saw this morning, we cannot do otherwise.

Scripture is important on this, but it is good to know the science too. Some want only to think about Scripture, and forget the science, but when it comes to bioethics I have learned something. If you do not know what the science says, you cannot begin to understand how the Scripture applies. With regard to the scientific nature of this question, the late French geneticist, Jerome LeJeune, said before a Senate Sub Committee in 198,

To accept the fact that after fertilization has taken place a new human has come into being is no longer a matter of taste or opinion. The human nature of the human being from conception to old age is not a metaphysical contention, it is plain experimental evidence. (See Francis Beckwith, Defending Life, p. 68)

Science tells us that the human embryo is human, and nothing else, it is living, and nothing else, and it is a "being" meaning it has independent existence as a separate entity. So it is a living human being, and nothing, absolutely nothing else and nothing less.

Even secular bioethicist Peter Singer, whom I mentioned this morning, acknowledges this: 
I accept . . . that the early embryo is 'human life.' Embryos formed from the sperm and eggs of human beings are certainly human, no matter how early in their development that may be. They are of the species Homo sapiens, and not of any other species. We can tell when they are alive, and when they have died. So long as they are alive, they are human life. (Singer, 2004)

You think about that. Peter Singer is no friend to the doctrine of the sanctity of life, as we saw this morning. He holds that some human life is of more value than others, and even that some animals, like adult chimpanzees, are of more worth than a newborn human, let alone embryonic humans! But despite this, he does not deny that human embryos are, in fact, living humans. Something that the technology that enable us to generate human embryos outside the woman has done is made us very aware that the human embryo is, indeed a separate being that can come to be and exist independent of the mother, thus not "part" of the woman.

All of this understanding gives us scientific backing to the Scriptural idea in Psalm 139 that even when we were in our embryonic stages in the womb "yet unformed" but "being formed in secret" we were known by God, as David put it. The question of the moral significance of the human embryo is not something to get over, but to revisit, especially in light of new technologies that take us beyond Roe $v$. Wade into the wonderful world of artificial reproduction and genetic engineering.

II. Bioethics beyond Roe.

This prepares us to evaluate some important issues raised in the drama. The drama depicts a young, Christian couple ready to start their family who were blindsided by the modern technology. They had no idea what options it would give them. In this future scene, baby making is done primarily in the lab to ensure the best possible genetic results, only "healthy, disease and disability free boys and girls," and help parents have a child of their design and choosing. It demonstrates an incredible power over the human embryo, in its generation, manipulation and destruction which we increasingly gain through our technology. But as long as God's people lack insights informed by God's word into these issues, as Christian bioethicist C. Ben Mitchell puts it, "at best they will continue to capitulate to so-called 'experts' all the while intuitively feeling that something is not quite right about the direction they are leading us" (Mitchell 1995, 132).

\section{A. The Issue of Medical Technology}

First of all, this Christian couple is using technology, more specifically assisted reproductive technology. Let us make it clear that technology is not bad in and of itself. Christians, because they stand against some uses of technology are falsely accused of being anti-technology. This could not be further from the truth. Any Christian, in fact, who 
takes such a stance will 9 times out of 10 come out to be a hypocrite, because it is impossible for us to live without technology.

In a sense, the doctor was right, God did give us "the minds to develop technology." According to Scripture, God created humanity to have "dominion" over all other created things (Genesis 1:26-28, Psalm 8:5-9). Technology essentially gives us power over our natural limitations to enhance our lives, and there is nothing intrinsically wrong with this. Humans, are, you might say, technological by created design. I would even go so far as to say that anything that God does by miracle, giving sight to the blind, hearing to the deaf, and the ability to walk to the lame, as well as opening the barren womb, are legitimate uses of technology as God's image bearers. So even assisted reproduction can be a technology that honors God insofar as it helps the infertile to be fruitful and bring forth God's image into this world, which is what He created us as male and female to do. So there seems to be nothing wrong with medical technology as such. Allen Verhey, Christian bioethicist at Duke Divinity School puts the issue clearly,

It will hardly do to adopt a casual anti-technological spirit . . . [this] would [require that] we regard respirators, dialysis machines, insulin, and penicillin illicit . . . it is slothful to suppress and refuse the dominion that has been given to humanity as a mandate and a blessing. The question should not be whether human beings will 'play God' or not - God settled that issue by making us image bearers and stewards. The question should rather be whether or not persons are exercising their God-given dominion responsibly. It would be moral sloth and folly to reject medical technologies, including reproductive technologies, simply because they interfere with natural processes.

But there's the rub, what does it mean to exercise our God-given dominion "responsibly?"

One of the fundamental principles of a biblical morality that guides choices in technology is that it honors God because it honors His image in man. As we considered this morning; God creates, cares for and carries us all the way, from conception to death, and our commitment to Him should be reflected in a commitment to His image as we consider various medical technologies, particularly ones dealing with the embryonic stage of human life.

With any technology that affects our reproductive lives, one of our first questions should be, "Does this technology uphold the dignity of human life created in God's image from conception?" If the Leverts, who claimed to be Christians, had applied this principle alone they would have done some homework before ever setting foot in the clinic. They would have found out, ahead of time, that IVF, or in-vitro fertilization, would be used to generate numerous human embryos, most of which would not be given a chance to develop into fully grown human beings, and that the left-overs would be either frozen, discarded or destroyed for research purposes.

Granted, understanding whether a technology should or should not be applied, is not easy to discover, but this fact must not prevent us from asking questions and grappling together, especially as the church, in this process. If anything, it should create a sense of pause to really deliberate and discuss how to apply biotechnologies. While ethics is the quest for answers to our moral dilemmas, I think that an important part of ethics is asking good, 
open-ended questions; the kind that cause us to pause, and even hesitate, in light of the numerous possible negative consequences for human life that they bring up, and for which there seems to be no answer.

\section{B. The Issue of In-Vitro Fertilization (IVF)}

This is the technological breakthrough that has made so much of the other technology in common use today possible. In vitro fertilization, where embryos are generated outside a woman's womb in a glass Petri dish by mixing sperm and eggs, has been used by thousands of people, even many Christians, to conceive children, since 1982. I have already stated that this procedure is not morally wrong as such. But many Christians, as illustrated in our drama, use this technique to have children without reflecting on its potential moral pitfalls. As guardians of God's image in humanity, we, the church, cannot default on this matter.

1. Generating multiple embryos is problematic if there is no plan in advance to take care of them. We know that Scripture tells us that God created us in his image and likeness, and it is clear that we procreate our offspring in our image and likeness, after God's example Genesis 5:1-3.

a) When God created man, he made him in the likeness of God (Gen 1:26).

b) He created them male and female and blessed them. And when they were created, he called them (named them), collectively, "man" or humankind (Gen 1:27).

c) He placed them in Eden (a "pleasure" garden) (Gen 2:8).

d) He then directly provided for the immediate needs of His offspring (Gen 2:9).

e) When Adam ... had a son in his own likeness, in his own image; . . he named him Seth. (Gen 5:1)

After God's own example we should be committed to providing for the wellbeing and blessing of our offspring, and grant them an opportunity to fellowship with us and be nurtured by us, much as God did when He prepared the Garden of Eden, literally the Garden of "Pleasure," for His original offspring. Are we not living up to this biblical model if we do not provide for the well-being of all the offspring we procreate? It's something worth pondering, don't you think?

If you are not ready to have more than one child, then do not have them generated in the lab. Think of all of them as your offspring, and think, as a Christian, like we suggested above, about how you are going to provide for their well-being before having them generated in lab. These issues have practical application to students and gametal donations. Should you college-aged students donate your sperm or eggs for purposes of compensation (college money) or even compassion (helping infertile couples have a child)? One of the 
guiding principles to resolve this question is to ensure that the offspring generated will be cared for and have an opportunity to be united to their parents.

2. The issue of egg freezing

Now technological advances have enabled us to freeze eggs, which could be a blessing in that it could enable us to fertilize one embryo at a time, and thus result in our not having to freeze and discard unwanted embryonic human beings. With this new technology, multiple embryo generation could become a thing of the past, and we who hold to the sanctity of the life God has created might be able to welcome this. But, let us also be aware that just because we can freeze eggs does not necessarily make this a good use of technology. There is still much discussion needed on these matters, like whether it is right for a woman to put of having children so late, or even having such control over their biological clocks.

3. The issue of embryo "deselection" and selective reduction.

It troubled the Leverts in the drama, and rightly so, to discover that not only were the "defective" embryos "deselected," but so also were the other "healthy" boy and both "very healthy girls." If they had done their homework, and asked the right questions, they may have never been faced with this dilemma. Is it consistent with God's moral will and character to generate embryos, even healthy ones, and then deselect, meaning to destroy, them because they are not wanted?

\section{The issue of sex selection}

The first decision the Leveret's had to make with the geneticist was to select the gender of their offspring. They were given two boys and two girls, as the doctor said, and they had to decide which "one" out of four, they were going to implant. They selected one of the boys. Sex selection is a live option provided by our current reproductive technology!

a) The availability of sex selection services

Just type in "Gender selection services" in your Google search and see what you get. Let's say you heard of this marvelous technology and wanted to use it to make sure you got that boy or girl first. One of the first entries you would see is, "The Fertility Institutes of Los Angeles, Las Vegas and Mexico." This clinic, as we soon discover, boasts "OVER 3800 CASES: $100 \%$ SEX SELECTION SUCCESS" Other fertility clinics boast not only its success, but provide money back guarantees if not completely satisfied with the results!

b) The procedures of sex selection

If we were to put on our "sanctity of human life" lenses in looking at this site, what should we pay attention to? 
In a real life case they worked on they stated, "The couple wisely elected to proceed with the IVF-PGD option. They were rewarded with a twin pregnancy that resulted in the birth of two healthy, male infants. While we exist to provide high quality medical services, we very strictly adhere to guidelines that have a history of providing excellent outcome results."

One of the first red flags for the believer looking at a site like this is that they use "IVF-PGD option." We have already considered the pitfalls of IVF above and I will soon talk about the issue of PGD, and seeing how, putting these things together, should raise red flags to a believer.

Another red flag should be raised at the statement "we very strictly adhere to guidelines that have a history of providing excellent outcome results." A "results" focused ethic can be problematic, because this way of thinking usually accompanies an "end justifies the means" way of doing things. Consequently, as long as you get the two male children you want is all that matters; it does not matter what happens in getting there. Let's see what this means.

They denounce earlier technologies of sex-selection. "Because no sperm separation method thus far developed has produced the high level of sperm separation ... needed to provide gender outcome success levels greater than $90 \%$, further work to perfect the sex selection process is being studied." Any problems here? Well, as we will see, with the low success rates (outcomes) that sperm separation technology has yielded, fertility specialists have moved to embryonic selection. So in the next line they tell you what this more successful method is. Their claim is that, "PGD (preimplantation genetic diagnosis) has taken sex selection to the next and most successful level ever (greater than 99.9\%). Results from our PGD process far exceed reported results from any and all other processes." So by now you should really be asking "what is PGD?" Is this something to be concerned about for an evangelical believer committed to the sanctity of life?

PGD, or pre-implantation genetic diagnosis, is exactly what the couple was presented with in our drama. It involves actually "deselecting" the embryos, healthy or not, that are unwanted. Just like this clinic claims, "Unlike many programs offering sex selection only to very limited couples with known genetic disorders in the family we make sex selection available to all patients seeking to balance their families or assure themselves that a pregnancy will result in ONLY the gender outcome they desire."

Thus, it does not matter that even "healthy" embryos are discarded in this procedure. They are not going to limit this technology to merely screening out the unhealthy or genetically defective embryos, no, they will do what it takes to get the results you seek. The "end," a child of the specific gender of your choosing, justifies the "means," discarding (probably killing) the embryos (even healthy ones) of the gender you do not want.

Now they tell you, "REMEMBER: Nearly all couples qualify for sex selection using the PGD method, which provides near 100\% (99.99\%) success . ..!" What they are saying is that it is all about results, and it really does not matter if they have to kill healthy embryos to ensure those results.

To summarize, sex selection is made possible through two methodologies: 1) Sperm sorting, which is more traditional and not as effective (to bring the desired results and 2) Embryo selecting, which is almost $100 \%$ effective, since we can tell the sex of any 
given embryo, but this necessarily requires the discarding of the embryos of the undesired gender! There is no way around this.

\section{c) The ethics of sex selection}

In research reported in Science magazine almost $100 \%$ of Americans polled said that they would utilize sex selection technology if it was "relatively simple." Of these, 90 percent said they would want a boy first, and 72 percent, they would want a boy if they could only have one child. (Anderson, 2005, 77-78) As we saw, sperm selection is less effective, but even if it works, and there is not a selection of one embryo over 3 other "healthy" candidates, as the drama depicted, is it ethical? Is any gender selection ethical? How do we decide on this one?

The technology is becoming increasingly effective to the point that fertility clinics are offering $100 \%$ money back guarantees if the couple does not receive their selected gender! With this increase in effectiveness, we can be sure that the American population will resort to it. Bioethicist Kerby Anderson warns "as more couples choose this procedure and as its effectiveness increases, the impact on society would be significant" $(2005,78)$. Should we as believers?

The most significant immediate impact would, of course, be that most people would choose boys first, or boys only, as we have seen. Just like the couple in the drama, the first pick is the "older brother" and "first born son." And since most US couples these days are selecting to have only one child, still the majority would pick an only son.

Widespread increase of the number of boys would be a silent discrimination against girls, and a nation of older brothers and younger sisters could imply that women are second-class citizens; that boys have more value than girls! In order to prevent such disproportionate ratios and implied sexism would the government have to step in and start legislating sex selection? What a political mess that would be!

As we have seen in countries like China and India, sex selection, and male preference have had disastrous consequences like abandonment, abortion and infanticide! While these are heinous crimes in our minds, what difference to a Christian is the issue of "deselecting" human embryos in a lab and washing them down the drain because they are the "wrong" sex? This is equal to abortion in our view.

Anderson simply asks questions, as good ethics does; Does the option of sex selection mean a right to sex selection, and if it becomes a right to select the most fundamental aspect of our children, will a demand for secondary characteristics like eye and hair color, athleticism, and even academic prowess follow? Will the "right" to sex selection lead to demanding the right to designing our children as we see fit?

In a more liberal article on About.com entitled "Gender Selection: Ethical Considerations and New Technologies" it is noted,

If, however, we are only doing [sex selection] because we can and because there is a consumer demand, then the path of "designer babies" remains very much open to us, and there is every reason to think that society will take it. Clearly, then, it is incumbent upon us to create those ethical guidelines and be certain about what we are doing and why. 
There seems to be one legitimate use of sex selection. We know that some diseases are sex specific, and if a woman who is known, for example, to be a carrier of hemophilia, selects to have a girl rather than a boy (because hemophilia manifests only in males) this could be considered a God-honoring use of the technology, but only through sperm selection, definitely not embryo selection/destruction.

\section{The issue of Preimplantation Genetic Diagnosis (PGD)}

This brings up the next issue we need to address tonight. We have already introduced it, but it requires more attention. The geneticist in our scenario had screened out the embryos for "major inheritable diseases," and only offered "healthy" candidates for the Leverts to choose. This is the process called pre-implantation genetic diagnosis. It is only possible through in vitro fertilization and the production of numerous embryos.

The procedure, of course entails the "deselection" or discarding/destroying of defective embryos. This is not only deliberate abortion, and thus subject to the same critique we would give any abortion, but it is abortion with a view to societal perfection. Critics of PGD, and not just Christians, are concerned that it revives a eugenics mentality.

Eugenics means "good race" and has a utopian vision for creating a disease free, disability free, society. This is what drove the sterilization programs in our own country, and the abortion and euthanasia programs in Nazi Germany during the 1920s to 1940s. The view was to create a perfect society with no genetically undesirable people, including people of undesirable races.

Through PGD we can eliminate certain disabilities and diseases in our society. This sounds good, and if we could do this without destroying the disabled and diseased, it would be a God-honoring technology because it is a technology that honors His image in man, and enhances human health. Or is it? What should be our attitude toward the disabled and diseased in our society? Should we "weed" them out at the embryonic level, or "welcome" them as loved ones to our communities? Scripture seems to point us in the latter direction.

In Exodus 4:10-11 we find the familiar story of God's call to Moses. After this call, Moses objects,

O Lord, I have never been eloquent, neither in the past nor since you have spoken to your servant. I am slow of speech and tongue. The LORD said to him, "Who gave man his mouth? Who makes him deaf or mute? Who gives him sight or makes him blind? Is it not I, the LORD? Now go; I will help you speak and will teach you what to say.

God's attitude is that disability in a human does not hinder His ability to use them. We see here the idea that God is NOT limited by our limitations; our "handicaps" are not His hindrances.

Now the word for "made" here is very instructive, and even troubling. It implies purposeful activity. God takes responsibility here for the blind, the deaf and the dumb in the world. He says, I "appointed" them, which literally means, He "set them in place." 
In John 9, Jesus actually implies that blindness may not be the result of sin or falleness, but to show God's glory (John 9:3). His grace is sufficient and His strength is made perfect in our weakness (2 Corinthians 12:9), said the apostle Paul.

We know that some people are born with more natural limitations than others, but we all have them, and our technology can be used to help us overcome them, and we should celebrate technology that gives sight to the blind, or helps the lame to walk, as long as we hold as a first principle of technology to do no harm and particularly not to deliberately cause the death of God's image bearers, even if they are diseased and disabled.

But as it stands, this is not the case. Those who see no value in the embryonic human have no qualms about killing them. But this is exactly what PGD presently entails. In our view, the killing of an embryonic human with Downs or diabetes in the lab is no different than killing a newborn or even adult human with these diseases!

In PGD human value is reduced to genetic make-up. It is not rooted in the idea that human beings have value simply because they are human, and thus created in God's image and likeness. In a sanctity of life ethic, the main issue is to develop technologies and therapies that do not require destruction of embryonic humans, but rather technologies that take account of the fact that every life, even embryonic life, is valuable to the God who "carries us from conception even to old age."

The couple asked the doctor about leaving some things "up to God." This was in the context of her referring to the defective embryos. What should we "leave up to God?" We should leave up to God the authority that He has to tell us that killing His image bearers is morally wrong. Unless He does it, or He orders it, we have no prerogative to decide who lives and who dies. He emphatically states in Deuteronomy 32:39 " Now see that I, even I, am He, and there is no God besides Me; I kill (lit. cause to die) and I make alive; I wound and I heal; Nor is there any who can deliver from My hand," and in 1 Samuel 2:6, similarly, Hannah confesses, "The LORD kills, and makes alive; He brings down to the grave, and brings up."

Conclusion:

There are several other issues that we could bring up as we analyze this scenario, but time will not allow this, so in closing, let me say, that what I see as one of the most important elements of this scene is the ignorance of the Christian couple who is seeking to have a child. The challenges that technology brings are great. Technology holds great promise, but also great peril. As technology continues to burn a path for us, and increases the potential for control over our birth, lives, and deaths, we must have burned in our minds this important first principle that humanity is created in God's image, and is thus sacred. 


\section{Sermon Three: Being the Church \\ in the Culture of Death}

20 January a.m. Service

Introduction:

I love the lighthouse. Besides being beautiful architectural structures, the lighthouse has meaning to me because of what it stands for, literally, but also what it stands for symbolically. Literally, the lighthouse stands to protect human life and human interests. They literally stand, that is, because of the worth of human life. Before Congress mandated the construction of lighthouses along our nation's shoreline in 1789 there were 100's of thousands of shipwrecks off the Atlantic coastline, giving earning it the ominous name, graveyard of the Atlantic. Lighthouses allowed safer travel for millions and ensured necessary food and supplies made it to port; all an implicit affirmation of the value of human life.

I also love the lighthouse for what it symbolizes. The following story illustrates this point.

A ship is caught in the middle of a huge storm on the sea. The captain sees a bright light ahead and it seems to be in the path of the ship. The captain sends out a message: "Change your course 20 degrees south we are headed your way." A few moments later the ship receives a message: "Change your course 20 degrees north." The captain, not very pleased with this, has another message sent: "Change your course, we have an important mission" As the ship comes closer to the bright light it receives a message: "Change your course , I have an important mission." The captain is now completely angry. Another message is sent: "ALTER your course this is an order, I AM THE CAPTAIN OF A BATTLE SHIP! Thinking this has settled everything the captain is shocked to know another message is being received ATTN: You must alter YOUR course, I AM THE LIGHT HOUSE!

The lighthouse represents unchanging authority by which you must guide your course. No matter how much authority you think you have, you, like all others, must chart your course by the lighthouse to be safe. You cannot chart your own course, it will not work, and it is dangerous. The light is there for a reason. To guide you safely.

Taking these two things together, I want to talk to you about the Being the Church in the Culture of Death. We are a lighthouse, we are to stand and affirm the dignity of human life, and protect life, from its earliest stages to its end, and we are to proclaim and practice principles to guide us and our culture through the dark and dangerous waters of this culture of death.

This morning, I want to introduce you to the culture of death with regard to the push for euthanasia in our country and what we must do and say to be the light. Tonight, 
I hope to talk about some practical biblical and medical guidelines for end of life decisionmaking.

I. What is the "Culture of Death?"

The culture of death is a term that the late Pope John Paul II coined in an address in 1998 in which he identified not just abortion, but embryo research, assisted reproduction and euthanasia among other things as generally characteristic of this culture of death. In response, he charged, "Society must learn to embrace once more the great gift of life, to cherish it, to protect it, and to defend it against the culture of death."

God, we know, charges His people to "choose life" (Deuteronomy 30:19). In light of this we, the Church, must ask; "What does faithfulness to the God of life look like in our bioethical decision-making?" especially our decisions about euthanasia.

\section{Arguments for Euthanasia and Doctor Assisted Suicide}

Euthanasia literally means "good/easy death" and has to do with taking deliberate steps to end suffering by ending life; or killing whether by passively withholding or withdrawing necessary treatment, or actively administering a drug that would hasten death.

Proponents of legalized active euthanasia argue five basic points for its legalization and that our doctors should be the ones to "deliver" us from our suffering and pain.

A. Autonomy - This literally means "self law" and has become perhaps the most important legal term today. Autonomy has to do with the right to self-determination and govern one's own life without interference from the government. It's my life, it's my body, and if I come to the place that I no longer want to live, they argue, I should have the right to choose when and how I die.

B. Mercy/Compassion - We all know that dying can be a horrible, painful experience involving deep physical and emotional suffering. Proponents of euthanasia simply argue that no one should be forced to suffer at the end of life by keeping them alive, even if they are not hooked up to life-sustaining technology that can be removed. After all, we do it for the animals to spare them suffering, so why not humans?

C. Quality of life - This argument is that we may come to the end of our lives and be suffering or just have such a diminished quality of life, that we should be able to say that my life is no longer worth living and have euthanasia available.

D. Medical Authority - Advocates argue that we want to die at the hands of our doctors because they are the gate keepers of the drugs that can give us a swift and painless death if we wish for it. Most suicide without doctors, as we know, is messy and painful. 
E. Economics - It simply places great burdens on families to care for dying loved ones who show no signs of recovery. That money could be put to better use. It also drains our health care system to care for the dying.

Presently, in the state of OR doctor assisted suicide is legal, but nowhere in our country is euthanasia legal. In OR doctors prescribe lethal drugs but the patient has to take them him or herself. Euthanasia, as is practiced legally in the Netherlands and Belgium, involves the doctor in the actual administration, via injection, of the lethal dose, much like we do with animals we "put down." This is the kind of ending of life "treatment" that the euthanasia movement is pressing for in the US.

III. Arguments against Euthanasia and Doctor Assisted suicide

This argument runs along three main lines.

A. Legal

1. $14^{\text {th }}$ Amendment

There is no doubt that suicide and requests for assisted suicide were occurring in our country at the time the $14^{\text {th }}$ amendment was ratified in 1868 . This amendment protects people's liberty and provides equal protection under the laws." Yet even then, our founders saw no right to suicide or assisted suicide in that amendment.

More recently, the SC ruled on the issue in 1997, the verdict was unanimous that there exists no right to die in the constitution. Proponents argue that the same liberty and privacy rights that give women the right to abortion, also give individuals the right to terminate their own life by their own choosing and the right to have their doctors do it. The high court has not seen it this way. In fact, then Chief Justice William Rehnquist wrote,

The history of the law's treatment of assisted suicide in this country has been one of the rejection of nearly all efforts to permit it. That being the case, our decision led us to conclude that the asserted 'right' to assistance in committing suicide, is not a fundamental liberty interest protected by the $\left[14^{\text {th }}\right.$ amendment $]$.

2. Medical

a) The history of Western medicine has consistently proscribed it.

(1) The Hippocratic school set the precedent in $4^{\text {th }}$ century Greece when it Announced in their Hippocratic Oath in $4^{\text {th }}$ century B.C. :

I will follow that system of regimen which, according to my ability and judgment, I consider for the benefit of my patients, and abstain from whatever is deleterious or mischievous. I will give no deadly medicine to any one if asked, nor suggest any such counsel; and in like manner I will not give to a woman a pessary to produce abortion. 
We should note that even in their own times, the Hippocratic doctors were counter culture affirming life in their own culture of death where suicide, euthanasia, abortion and infanticide were prevalent.

(2) More significantly, perhaps, is that the American Medical Association continues to stand against euthanasia, and even DAS.

It is understandable, though tragic, that some patients in extreme duress--such as those suffering from a terminal, painful, debilitating illness--may come to decide that death is preferable to life. However, allowing physicians to participate in assisted suicide would cause more harm than good. Physician assisted suicide is fundamentally incompatible with the physician's role as healer, would be difficult or impossible to control, and would pose serious societal risks.

b) This brings up a second point under the medical argument. Doctor assisted suicide would redefine the medical profession and doctors would not only be our healers, but our killers.

People can kill themselves. The question is why should doctors . . . be involved in helping people to kill themselves? ... . doctors have always said we are not in the business of killing people, of giving lethal doses of medicine, we are here to use our skills solely to heal, but never to harm. - Dr. Mark Cheesman, Geriatrics.

c) Another concern is that making it legal for doctors to actively kill their patients would erode the patient doctor relationship.

Medicine is built on trust; a trust that one's doctor has one's best interests at heart and wants to do patient good, and not harm. But if the "right" to die is instituted, it will erode into a "duty" to die, it is argued, and doctors may want to assist those who cannot speak for themselves to request assisted death. This is largely because the right to die will someday be considered a duty die, and doctors who are dealing with patients who cannot speak for themselves may take it upon them to, in the patient's best interests, eliminate suffering by eliminating the sufferer.

d) Finally, it would also detract from the incentive and motivation to improve and perfect palliative medicine.

I will address this more tonight, but for now let's just say it is comfort care provided for the dying, the goal of which is no longer to cure, but to care by relieving symptoms until the patient dies of his or her underlying disease or injuries. If euthanasia becomes legal, there would probably be less of a push to control end of life pain, since we can kill the pain by killing the patient. It would be much easier to do that than to find ways to relieve in the living, yet dying, person. 


\section{Social}

The voluntary euthanasia of the consenting can easily creep into the involuntary and nonvoluntary euthanasia of those who have not expressed a wish to die, but whose lives are considered no longer worth living by others. In fact, it seems logical, as well as nearly inevitable that involuntary euthanasia will follow the legalization of voluntary euthanasia. The examples of Nazi Germany and more recently the Netherlands and our own state of Oregon seem to bear this out.

a) Nazi Germany

1920 Germany had set up legal safeguards so that euthanasia in that country would not be used on the non-consenting or break the will to live. It all started with a simple question posed by Dr. of Jurisprudence Karl Binding and Medical Doctor Alfred Hoche in their book The Release of the Destruction of a Life Devoid of Value, where they ask, "Is there any human life that has to such a degree lost its legal rights, that its continuation is of no value for itself or to a society"? The answer to the question, of course, was a resounding "yes" and to what this question led by the 1940 s we all know.

Reflecting on the situation in Germany, Nuremberg investigator Dr. Leo Alexander, in the NEJM in 1949, states,

Whatever proportions these crimes finally assumed, it became evident to all that they started from small beginnings. The beginnings at first were merely a subtle shift in the basic attitudes of physicians. It started with the acceptance of the attitude, basic to the euthanasia movement, that there is such a thing as a life not worthy to be lived. This attitude in its early stages concerned itself merely with the severely and chronically sick. Gradually the sphere of those to be included in this category was enlarged to encompass the socially unproductive, the ideologically unwanted, and the racially unwanted and finally all non-Germans.

Then he adds this chilling warning, "At this point, Americans should remember that the enormity of the euthanasia movement is present in their own midst."

\section{b) The Netherlands}

Here euthanasia has been legal since 2002, and infanticide since 2004, but practiced for two decades prior to that. A government report disclosed that of the 3340 people that died by euthanasia one year, 1040 of them $(31 \%)$ died without consent. The Netherlands is a small country; I have heard it compared in size to our state of Rhode Island! If we were to extrapolate from the studies 
done in the Netherlands as to what would happen if euthanasia became legal in our country, we could be looking at over 41,000 acts of euthanasia in one year, with 16,000 of those being involuntary cases where doctors acted in their patients' best interests by killing them.

The trend of starting with adults; suicide and mercy killing, and then extending to other groups has been clearly documented in Holland. So I and many of my colleagues as pediatricians see the potential for the slippery slope extending to other vulnerable age groups, particularly newborn babies who are unwanted. - Dr. John Wyatt, Pediatrics

Leon Kass, first Chairman of the President's council on Bioethics, writes in a paper on this subject,

Insistence on voluntariness as the justifying principle cannot be sustained . . . 'Why,' it will be argued, 'should the comatose or the demented be denied such a right or such 'treatment' just because they cannot claim it for themselves? . . . Because most of the candidates for mercy killing are of this sort, the line between voluntary and involuntary euthanasia cannot hold, and ... the mentally impaired or comatose [will be] declared no longer willing to live because someone else wills that result for them.

c) Oregon and the "Duty to Die."

Another important social argument against euthanasia is that coercion and duress are inevitable. One's right to die will be considered by them, and others, their duty to die. Allen Verhey, Professor of bioethics at Duke Divinity School writes of how the "freedom" to have the option of euthanasia will actually result in a greater burden, as people laying dependent and dying, start feeling the need to "justify their existence." One must definitely wonder what would keep this from happening.

We can see this beginning to happen in OR where doctor assisted suicide, not euth. is occurring. Bioethicist Ben Mitchell observes,

Nearly two thirds (63\%) of patients seeking doctor assisted suicide in Oregon in 2000 , reported that their primary motivation was to avoid, 'being a 'burden on family, friends or caregivers,' compare this to the $26 \%$ of the previous year, and one can see a frightening trend.

Is this how we want our frail and elderly to feel? Like they are in the way? Philosophy professor John Hardwig of the University of East Tennessee thinks so, 
One has a duty to die when continuing to live will impose significant burdens emotional burdens, extensive care-giving, destruction of life plans, and yes, financial hardship - on your family and loved ones. This is the fundamental insight underlying a duty to die.

A duty to die becomes greater as you grow older ... To have reached the age of say, seventy-five or eighty without being ready to die is itself a moral failing, the sign of a life out of touch with life's basic realities.

In light of this, Hardwig envisions a future in which,

Physicians would no longer be agents of their patients, and would not strive to be advocates of their patients' interests. Instead the physician would aspire to be an impartial adviser who would stand knowledgeably but sympathetically by ... and discern the treatment that would best harmonize or balance the interests of all concerned.

What? Instead of being people to be cared for, the dying, and even nonterminal elderly, would be considered, and be made to consider themselves, burdens to their families, and not worthy of medical or other resources? Yes, there will be a strain on medical resources in the future, and tough decisions to make, and policies to develop, but to force people out of society and make them think they no longer belong? Even before they are terminal? Is that the solution? This sounds like Logan's Run writ large. Lest you think this is on the fringe, Hardwig's articles have been published in The Hastings Report, one of the foremost bioethical journals in the nation.

\section{Being the Church in the Culture of Death}

I want to suggest a way in which the church can be the church in the culture of death. The end of life does, we must agree, present us with some serious burdens. Dying is hard work. But Scriptures deal with the concept of burden bearing. Galatians 6:2 exhorts believers to "bear one another's burdens and so fulfill the law of Christ." Christ's law (John 13:35) was "that you love one another." So love, in a biblical sense, entails bearing the burdens of others. Implicit here is the insight that we are not to consider other people as burdens, but rather people with burdens. These burdens are not to be carried alone. Christ's people should, in true compassion (which literally means "suffering with"), bear them along with the afflicted.

There is an explicit and implicit moral duty here. The clear duty for those without a particular burden, is not to leave those with them alone in their suffering. The implied duty is that those who are suffering must allow themselves to be served, i.e. to be in a state of dependence upon others. Dr. John Dunlop commenting on Galatians 6:2.

Pain and suffering can be decreased as it is shared within a caring community. It must be one of our goals in the Church to develop a community that can feel deeply one another's pain. One of the ways God is glorified in His Church is when the 
members develop a depth of fellowship adequate to allow them to bear one another's burdens." But also says in that same passage, "This command is a charge to help others. At the same time it obligates people to allow others to help them. The older years often teach us how to depend more on others. There is, indeed, a ministry of dependence.

I'm sure you would agree; that is a mature Christian community.

One always hears how Job's friends were really not too friendly because they hastily concluded that Job suffered as he did because of some sin he had committed. The book of Job was no doubt partially written to debunk this thinking. It is a grave error to conclude that suffering in anyone's life is necessarily an indication that they have sinned. Yet despite his friends' poor display in the dialogues, their friendship is exemplary when they first hear of their friend's grave misfortune. In Job 2:11-13 Scripture records,

When Job's three friends heard of all this adversity that had come upon him, each one came from his own place ... For they had made an appointment together to come and mourn with him, and to comfort him. And when they raised their eyes from afar, and did not recognize him, they lifted their voices and wept; and each one tore his robe and sprinkled dust on his head toward heaven. So they sat down with him on the ground seven days and seven nights, and no one spoke a word to him, for they saw that his grief was very great.

There is definitely a place for a ministry of silent presence, especially with those who are suffering and in the dying process.

The significance of such a ministry for those who are anticipating their imminent death is seen vividly portrayed in the life of our Lord. In the throes of his agony in Gethsemane, Jesus gives a simple directive to his disciples to "watch and pray" with Him. Arthur J. Dyck makes the following insightful observation, "Jesus expected his followers to be in prayer with Him, and be a companion to Him while He was suffering." He then makes application for all those who call themselves followers of Jesus and what this example means for us in both medicine and ministry. He remarks,

In short, followers of Jesus owe compassion to those who suffer. What happened in the Garden of Gethsemane contains a very urgent message for all those who are attending the sick and the dying: Do not abandon the suffering; pray with them and for them; do not shun the suffering any of us feel when we are present to those who are physically diminished and suffering in any way.

He also powerfully says, "Suffering people need the support of others; suffering people should not be encouraged to commit suicide by their community, or that community ceases to be a community." And let me remind you, that Job's friends looked upon him and "did not recognize him." Our responsibility to those who are afflicted in such a way that we may not recognize them, or their presence is pleasant in neither sight nor smell, which is common when people are in the dying process, is to be there, and to be in prayer. Jesus admonished his disciples for not suffering with him, but abandoning him to do it alone. Doesn't this 
powerfully affirm the significance of a ministry of silent and prayerful presence when attending those who suffer deeply and are about to die?

\section{Conclusion:}

From this, we must conclude that pressure toward, or espousal of euthanasia and a duty to die. i.e. a "culture of death" is alien to a biblical ethic and life. The church, in imitation of its Lord, is a community that affirms life at every point and in every stage, no matter how weak, dependent or compromised. Dependency cannot be thought of as an evil or an undesirable condition. If someone voices a notion of being a burden, or hints at a duty to die, or if those who care for them echo these sentiments, the church must counter this mindset, that leads naturally to the demand for euthanasia, with an affirmation of their existence and their worth, and insist that, You are not a burden, you have a burden and I am here to carry it with you, and thus affirm their unchanging dignity and worth. Just like the Lord, as we learned last week, carries us all the way, so we carry each other all the way, from our embryonic stage, to our last dying day, protecting the life and dignity that God has given us. This is a large part of what it means to be the church in the culture of death. 


\section{Sermon Four: Biblical and Medical Guidelines \\ for End of Life Decision Making}

20 January p.m. Service

Introduction:

Play video clip from "Hamlet" starring Mel Gibson; "To be or not to be" soliloquy.

Now let me read from the Apostle Paul's meditation on death in Philippians 1:20-25 where he expresses his desire,

That in nothing I shall be ashamed, but with all boldness, as always, so now also Christ will be magnified in my body, whether by life or by death. For to me, to live is Christ, and to die is gain. But if I live on in the flesh, this will mean fruit from my labor; yet what I shall choose I cannot tell. For I am hard-pressed between the two, having a desire to depart and be with Christ, which is far better. Nevertheless to remain in the flesh is more needful for you. And being confident of this, I know that I shall remain and continue with you all for your progress and joy of faith,

I think the contrast between Hamlet and Paul is significant here. Hamlet was basically saying to depart and be who knows where is a horrifying thought, so I will remain in the flesh because it is more needful for me. His keeping from committing suicide at that moment during that moment of despair and contemplation of death was actually for selfish purposes.

On the other hand we read these words of brother Paul, the Apostle in Philippians 1:21; "for to me, to live is Christ, and to die, gain . . . having a desire to depart and to be with Christ which is far better, nevertheless," He told the Philippians, "to remain in the flesh (his earthly existence) was more needful for you." Paul was human and he was dealing with the possibility of death too, contemplating his possible execution while sitting in a Roman prison.

In sharp contrast to Hamlet, Paul knew exactly what would become of him when he died. "To depart and to be with Christ is far better," he said, but if Paul could have ended his own life, he seems to imply, he would not. While the suffering of life drove Hamlet to want to end it all, despite the suffering of life Paul knew that to remain alive was "more needful" for those to whom he ministered. Paul was willing to endure suffering for the difference he could make in other people's lives for Christ. Hamlet, on the other hand, chose to endure the "slings and arrows of outrageous fortune" and the "thousand shocks that flesh is heir to" because he feared that "undiscovered country, from which no traveler has returned," and of which we know nothing.

Paul is not concerned about an "undiscovered country," for him to die was gain, because to die was to be in the presence of his Savior, Jesus Christ. We are addressing death tonight, but I want to open with this word. When you put your trust in Jesus Christ as your Savior, the risen and living Savior who has gone ahead of us to that "undiscovered 
country" you need not fear it! For you, like Paul, death is a mere departure to another place, a better place, not a better place because of the place itself, but because of the Person who awaits there for our arrival.

Isn't it good to know that death is a doorway to the presence of Jesus? This is the hope and the confidence that has given the gospel its power. But, here's "the rub;" knowing what will happen after we die, does not necessarily make the dying process any easier. Woody Allen has quipped "I'm not afraid to die, I just don't want to be there when it happens." We laugh because we can identify with that, can't we? We would love to sidestep the dying process, and just go on and die. Oh that each of us could simply go to sleep seemingly healthy, and then just not wake up. But such is probably not the case for most of us. Most of us will not simply die, but go through the process of dying.

Although this does not make things easier, it does give us understanding. The warning that God originally gave Adam was that "in the day you eat of [the tree of the knowledge of good and evil] dying, you will die." So it would seem that part of the curse is not just death, but the dying process as well, and the dying process involves disease, increasing disability and decay, which does not make for a pretty picture.

I think it is safe to say that there is no more difficult time in life than when we are coming to its end. This time brings not only deep emotional issues to the fore, but also challenges us with some difficult ethical dilemmas as well. The moral dimensions at the end of life can be, and usually are, especially troublesome. Dr. Ira Byock has observed, "unlike many areas of medicine in which it is the occasional case that presents an apparent ethical dilemma, care at the end of life is full of ethically poignant and emotionally charged situations." One thing that clearly complicates the question of dying is advancing technology. Farley highlights the nature of the quandaries that technology forces upon us.

It is because of the dying process, that I come to you tonight with fear and trembling. Because while I strongly believe and have repeated to you several times that good ethics is about asking the kinds of questions that create pause and that prevent action because of so much uncertainty, I cannot hide behind that principle when it comes to the kinds of questions we will be dealing with tonight. Is it ever OK to pull the plug? Should believers issue advance directives? What if there are conflicts between siblings over what to do with a dying parent? What is palliative care and when should I seek it? The doctor removed the ventilator and gave a dose of morphine to ease my teen daughter's pain caused by cancer and she died within an hour, was that euthanasia? I feel so guilty. I wish there were easy answers to all of these, but I know that there are not.

Our commitment to the sanctity of human life can actually make our guilt greater, and our decision-making more difficult because we do not want to cross that line to euthanasia. Each situation is different and dynamic. Sadly, I know I will not answer all the specific questions you may have, and I also know that I feel a grave responsibility tonight because I do not want to encourage anyone to step over the line of euthanasia even inadvertently. That is why I come to you with fear and trembling.

I wish I could address everything there is to address and as I have told some of you from the start of this series, I know that I am just "scraping the tip of the iceberg" on these issues and that is frustrating for you and for me. That is why I am grateful for the opportunity to teach a LTE starting this Wednesday on bioethical issues. This will give us a 
context for asking questions and thinking about them together and specifically seeking to figure out what faithfulness to a biblical ethic looks like in light of them.

But along with my fear and trembling, I come to you confident that I can give you some guidelines that will help you in making some decisions and hopefully ease some of the guilt you may be feeling over decisions you have already made or seen made in your family. I want to address three practical areas of concern when it comes to end of life decision-making: 1) Planning for your dying, 2) Palliative care and 3) "Pulling the plug." But I am going to sandwich these discussion under two foundational biblical principles. The Power and sovereignty of God and the Passion of Christ and what these mean for us as believers.

\section{The Power and Sovereignty of God}

Christians can be tempted to give in to the cultural pressures around them when it comes to the potential misery and suffering of the dying process. After all, we are also human and, although carefree about what becomes of us after we die, we do not necessarily feel any different from others about dying. No one, whether Christian or not, really wants to be indefinitely kept alive through artificial means, or burdensomely hooked up to tubes and machines. Dr. Margeret Farley states,

In large part our fears are in being given too much medical treatment, being kept alive too long, dying not in peace but in a wild frenzy of efforts to give us a little more time to live. The radical possibilities introduced by modern medicine lead ironically to scenarios of dying that have become unacceptable to many individuals. To more and more persons, it appears that the only way to retain some control over our death-to die a death marked by conscious self-awareness, with knowledge of our ending, surrounded by those we love-is to take our death into our own hands.

This is an era in medicine when one of the most important principles is patient autonomy. As far as how Christians should be thinking about autonomy, it is true that, especially as Americans, we do have certain legal freedoms, but we must ever acknowledge that God is the ultimate authority when it comes to all of our decisions, including those about our dying. John F. Kilner puts the issue bluntly when he states, "to assume ultimate responsibility for one's life [by deciding when it should end] is to reject God, no matter when, in the course of life, one elects to do so." The necessary perspective for the believer is that we are, as Paul said in 1 Corinthians 6:18, "not our own." Our focus must not be upon human autonomy, but rather divine authority. We are not self-determined sovereigns who depend solely on our reason to make decisions, but rather submissive stewards who look to God's revelation where we discover that our Maker reserves the right to end a human life and forbids homicide (See Gen 9:5-6, Ex 20:13, Deut 32:39 and 1 Sam 2:6). Lest the reader think that this notion of God's ultimate sovereignty is understood only by Christians, even Hemlock Society founder Derek Humphry affirmed this position when in the introduction of his book Final Exit, addresses his readers saying, 
If you wish to deliberately leave this world [but are not on any kind of life-support] then active euthanasia is your only avenue. Read on carefully. (If you consider God the master of your fate, then read no further, seek the best pain management available and arrange hospice care.

It is striking that such a proponent of active euthanasia knows that it is inconsistent with a Christian worldview to seek euthanasia. Having said that, let's talk about the practical matters I mentioned to you.

II. Planning for our dying.

By this I do not mean writing up a last will and testament, or making funeral arrangements. That's planning for our death. I mean planning for being in the dying process, and preparing an advance directive for health care. Generally, there are two kinds of advance directives (ADs). They instruct doctors as to what kind of treatment you want and do not want when you are incapacitated and unable to communicate. ADs are actually intended to prevent overtreatment and under treatment when we cannot communicate our wishes.

They also can help simplify the decision-making process for our loved ones because we have communicated our wishes. There are essentially two types of ADs that do this; 1) The Living Will and 2) The Durable Power of Attorney for Health Care (DPA)

Living Wills leave much to be desired because they are, in a sense, too rigid. The dying process is a dynamic time of continual flux and there is no one size fits all advance directive. If a living will states, "when I am mentally incompetent I do not wish to be kept on a ventilator" this could be your death warrant when a ventilator may, in fact, be what you need to return to health. DPAs are much more preferred. They do not state what you do and do not want done, but rather give that decision-making authority to someone you know understands and will respect your wishes and values as they work with the medical staff.

Tonight I do want to inform you of a special Advance Directive for Health Care that has been drafted by the Center for Bioethics and Human Dignity in IL. CBHD is a Christ-centered bioethical think tank on the campus of Trinity International University where I am doing my doctoral work. When Dr. Kilner first announced that this particular AD had been drafted, I was pleased. Here was a Christian bioethicist who had worked with other Christians to design a form that would make both over and under treatment virtually impossible. It also refers you to this book, which is written by Christians with a strong biblical foundation for sanctity of life and making decisions at the end of life that uphold that principle.

The ethical justifications of the guidelines included in this advance directive form, plus other ethical issues involved in end-of-life treatment decisions, are discussed in the easy-to-read 80-page End of Life Decisions question-and-answer book available from The Center for Bioethics and Human Dignity. I strongly encourage each of you to read through this book and to think through the issues it raises, in conjunction with completing the advance directive form. 
You can write your own AD and Living Will. Here is an example.

The Christian's Living Will

To my Family, Physician, Clergy, Attorney, or Medical Facility:

First: I as a Christian believe that

whether we live or die we are the Lord's Romans 14:8. Death is certain, but so is the faithfulness of God in death, as in life. With this high hope to sustain me, I wish to be as responsible in dying as in living. (You could even share the gospel with family and staff).

Second: To this end I implore all those responsible for my care and knowledgeable of my condition to be completely honest with me in the event of a terminal illness, that I may make my own decisions and preparations as much as possible.

Third: If there is no reasonable expectation of my recovery and I am no longer able to share my decisions concerning my future, I ask that I be allowed to die and not be kept alive indefinitely by artificial means or heroic measures. I ask that drugs be administered to me as needed to relieve terminal suffering even if this may result in my death. I am not asking that my life be directly or actively taken, but that my dying be not unreasonably prolonged if my condition is hopeless, my deterioration irreversible, and the prolongation of my dying an overwhelming responsibility for my family. (From Life and Death Decisions by Robert Orr, David L. Schiedermayer and David B. Biebel)

You can write your own Advance Directive. Combining ideas that you like, sharing your understanding of death and the gospel from a biblical viewpoint. What I would like to do in our elective is have an Advance Directive workshop where we can develop a document that communicates our Christian values clearly as well as our wishes when we come to the dying process. But these ADs bring up the two other questions I wanted to address tonight. Palliative Care and Pulling the Plug

\section{Palliative Care}

Simply defined, palliative care is specialized care for the terminally ill which focuses on comfort rather than cure in its goals and techniques. It emphasizes the alleviation of physical pain as well as the identification and meeting of emotional and spiritual needs for the patient and family until the patient dies from the underlying disease process. This is the goal of the hospice care movement founded by British physician Dame Cicely Saunders in England in the 1960's. One of the main tenets of the hospice movement has been Dr Saunders statement, "We do not have to cure to heal." I would add we do not have to cure to care. These goals seem to be very consistent with a biblical theistic worldview which accepts the inevitability of death, (that "there is a time to die") not trying to postpone it when it is imminent, or close at hand, but affirms the dignity and sanctity of human life, by comforting and caring for the patient until they die, but doing nothing to hasten their death (which Doctor Assisted Suicide would seem to make more common place). I like what Ira Byock, a prominent hospice care physician says. He doesn't want, necessarily, to argue against doctor 
assisted suicide, he wants to make it irrelevant by providing the best end of life care as possible.

Hospice usually occurs in the patients home, probably where most of us prefer to die, and does not involve aggressive treatment. People who move into hospice have normally been given the "six months" to live prognosis. People committed to palliative care are also committed to allowing death to occur in its time, and not fight it any longer.

A more controversial issue in palliative care is whether or not administering a dose of medication strong enough to kill pain, but which may also kill the patient, is equivalent to active euthanasia. Some call this "terminal sedation." (sedating the terminally ill until they die). This is also called the principle of double effect, and is consistent with not only the Western medical tradition, but even Roman Catholic theology and ethics which is very conservative and highly committed to the sanctity of life.

Dr. Robert J. Kingsbury, a Christian hospice physician, sees this level of care as being consistent with biblical principles, because the physician who applies the medication is doing so to fulfill the physicians mandate of benefiting the patient and doing no harm. In his view,

Terminal sedation is a recent addition to the lexicon of palliative care ... a survey of 61 selected palliative care experts, arrived at the following definition; "terminal sedation is deliberately inducing and maintaining deep sleep but not deliberately causing death in ... circumstances such as 'intractable symptoms at the end of life ... for which standard palliative care intervention had failed to provide adequate relief.

While it might be questioned as to whether the sedation itself hastens death, Kingsbury cites a study which "showed no statistically significant difference in survival from date of admission between sedated and non-sedated patients," (morphine does not kill) concluding that the "the need for sedation is an indicator of impending death and not a cause of premature death." Kingsbury further argues,

Patients who spend their last hours or days sedated are very sick. Even before they are sedated, these patients are eating and drinking substandard amounts, and artificial hydration and nutrition is usually contraindicated because it would increase the risk of pulmonary edema and other adverse effects. (2004)

Kingsbury answers critics, especially proponents of euthanasia who call it "slow euthanasia." Kingsbury insists that physician intent, although unknown for the most part, can be objectively measured to a certain extent by seeing how the medicine is administered.

Analgesics or sedatives are administered only for pain relief or distress if they are titrated to achieve specific end points (such as the absence of grimacing or moaning in patients unable to report pain) and not beyond. In contrast, the rapid administration of medication with no effort to titrate indicates that hastening of death was the first intent. (2004) 
Kingsbury has pointed out not only an important distinction, but also provided an objective standard for determining intent to some degree. He then conscientiously explains how such intervention is consistent with a biblical perspective by first affirming his belief in the sanctity of human life since it has been created in the image of God and the consequent responsibility that physicians have not only to their patients, but to God who is the giver of all life.

It seems that the Scriptures support the principle of palliative care, and by implication, terminal sedation. In Proverbs 31:6-7 we find the following instruction to a king, "Give strong drink to him who is perishing, and wine to those who are bitter of heart. Let him drink and forget his poverty, and remember his misery no more." The instruction is that kings are not to be drinkers of wine or strong drink since it distorts moral judgment, and thus issues in the perversion of social justice. Nevertheless, this same kind of drink is legitimate for one who is dying, so that individual can forget the impoverished and miserable condition of the dying process. It would seem possible that the narcotics used in terminal sedation are consistent with this biblical idea. Those who are suffering in their dying are to be given some kind of substance to help them "forget," their misery and by implication, to die in as little suffering as possible. Implicit also is the idea that actively killing a person in such a state is forbidden. There is no suggestion to suicide or assisted suicide in this text, but it would seem almost expected in this text about the dying if it was sanctioned by God.

IV. Pulling the plug

This is simply a commonly accepted metaphor for discontinuing treatment that has proven to be futile. Is it ever consistent with a sanctity of life ethic to allow death? In a conversation with Dr. Timothy Johnson, medical editor for ABC News, former Surgeon General C. Everett Koop, says the following about "euthanasia."

In any discussion of euthanasia I think we have to be very careful in defining what it means to help someone die "without pain." That could be interpreted as helping them by killing them; or actually helping them to commit suicide by providing them with the knowledge to commit suicide; or of standing back at an appropriate time and letting nature take its course while making the comfort of the patient of highest priority. Of that list of possibilities, I could do only the last . . . and have done it in my surgical practice.

Perhaps, Tim, I should stop talking philosophy for a minute and describe a real-life situation that I had to face all too often when I was a pediatric surgeon. Let's imagine, Tim, that you had a three-year-old little girl with an abdominal tumor, a neuroblastoma. I operated on your little girl, and after surgery it was appropriate to treat her with both radiation therapy and chemotherapy. Even though she has improved for a while, she still has a malignant tumor. You have brought her to see me, and on this office visit, I notice that she has been failing, and I think you have seen the downward trend, too, so I am going to sit down and chat with you about what I think we should do from now on. Here's what I would say (in ordinary 
practice I might take an hour to say what I'm going to write you in the next paragraph):

"Tim, I'm sure you can see that your little girl is failing, and I want you to know where we stand. I've done all the surgery that I can do. Further radiation and chemotherapy seem to me to be futile because of the spread of her tumor in spite of those methods of therapy. In fact, I am going to suggest that we discontinue the chemotherapy. Let me tell you why. On the one hand, if we discontinue treatment and do nothing for your little girl, I think that she will probably succumb to her tumor in about six weeks, but she will be without pain and without suffering. On the other hand, if we treat her with chemotherapy, on the basis of my past experience with similar problems, I would predict that she could live about three months, but before she died she would be in pain and might be blind and deaf because of the treatment. So, Tim, I recommend that we stand back and let nature take its course."

I don't think that's euthanasia; I think it's good medicine. I think it's good medicine for the child, for the family, for all of us. (Koop and Johnson 1995, 46-48).

I read that to you because $\mathrm{C}$. Everett Koop is a strong sanctity of life physician. In fact, he co-authored the book Whatever Happened to the Human Race with Francis A. Schaeffer. These are the most difficult times in life when we have to say the final good bye, and notice that the story was about a child, not an elderly patient; we never know when we will have to face this decision. It is in these times that we need physicians and agents for health care that really are committed to the SOL and committed to upholding our values and wishes. What I like about the Advance Directive I talked with you about earlier was that it required more than one physician's opinion.

When several physicians agree and tell us that the body is shutting down, the organs are no longer absorbing and assimilating nutrients from a feeding tube, and keeping that tube in may be causing more discomfort and pain to our loved one, shouldn't we remove it? I know it is ever so difficult because one of the ways we express love is to feed each other, but as we understand more about the physiology of dying, we realize that not only may tube-feeding increase suffering in the imminently dying, there are studies that show that dehydration actually has an anesthetic effect. Ask any doctor or nurse.

What we should be committed to is applying treatments on a trial basis, much like a prescription drug, and if it does not work, we should discontinue it. It is so much harder to discontinue treatment than to withhold it in the first place, but when death is determined to be imminent, it is not less moral.

What is especially difficult is foregoing treatment when people are conscious and aware of things around them. This is just so emotionally difficult, but we must assess each situation and determine whether the treatments being provided are preserving life, or actually merely prolonging death in an uncomfortable way.

We must make decisions, and they are not easy, I grant you, but let me highly recommend some reading material to you; Basic Questions on End of Life Decisions and Basic Questions on Suicide and Euthanasia. Hopefully we will get these guides in our bookstore and library soon. They are written from a distinctly Christian perspective which involves a strong commitment to the dignity and sanctify of human life. They provide invaluable information in a convenient Q\&A format, and are designed to give you quick, 
thoroughly biblical, and concise answers to tough bioethical questions. They are part of a larger Bio Basics Series which includes such subjects as issues in sexuality and reproduction, genetics issues and health care.

Hopefully, in the limited time I have had, I have given you perspectives and insights, and directed you to resources that will help you and your family when you face dying and the dilemmas it raises. I said at the outset that I wanted to talk about the three practical issues of Preparing for Dying, Palliative Care and Pulling the Plug sandwiched between the more theological perspectives concerning the Power and Sovereignty of God and the Passion of Jesus Christ. I opened with a discussion of our submission to God's power and authority, rather than succumb to the culture of death, now I turn to the passion of Christ.

\section{The Passion of Jesus Christ}

The word "passion" literally means suffering. We all know Jesus suffered for us, but let's think about that a moment and what it means for us in our dying. In His suffering, Jesus did not only take on death, he took on the dying process. Our Lord came in a time in history when humans had devised one of the most horrific forms of torturous death ever known; scourging and crucifixion, a methodology designed to cause one to die slowly and in excruciating agony.

The significance of this for our dying is that when we come to Jesus, we come to "a man of sorrows and acquainted with grief," One who is no stranger not just to death, but to the dying process itself. After His scourging and on that cross, Jesus felt his life slipping away as he slowly died. Most of us will not die suddenly, as we may desire, but go through the dying process. The very thing that humanity was cursed with because of sin. When we are in the dying process, slowly and even painfully feeling our life slip away, we should be able to look to Jesus, who endured the same, and realize that in Him we have One who knows our misery, having embraced it himself. Yes, we may suffer in dying, but let us realize that our faith reveals a God who did not leave us alone in that, but came and embraced that himself. As I reflect on this, I can never doubt His love for me.

Every time we have a baptism or a communion service, we should remember, as Jesus tells us to, that He knows our pain and suffering and the misery of dying slowly as well. He is a true high priest who is genuinely sympathetic with our suffering, because He, too, endured it. But every baptism and communion, although beginning with pain and suffering, ends with pleasure and celebration; the celebration of resurrection and anticipation of our Lord's return to deliver us, finally, from all death sorrow, crying and pain (Rev 21:4). Just as He came and shared intimately with us in the human dying process, so we will share with Him in the resurrection of the body, and so shall we ever be with the Lord! So we can say with Paul, confidently, "our light affliction (by which he meant all earthly affliction) which is but for a moment, works in us a far more exceeding and eternal weight of glory" (2 Cor $4: 18)$ ! 


\section{REFERENCE LIST}

Allen, Ronald B. 1984. The Majesty of Man. Portland, Oregon: Multnomah.

Anderson, Kerby. 2005. Christian Ethics in Plain Language. Nashville, Tennessee: Thomas Nelson.

Birch, Bruce and Larry Rasmussen. 1989. Bible and Ethics in the Christian Life. rev. ed. Minneapolis, Minnesota: Augsburg Fortress.

Blamires, Harry. 1963. The Christian Mind: How Should A Christian Think? Ann Arbor, Michigan: Servant Publications.

Blocher, Mark. 2005. Christian Worldview and Medical Ethics Part 1: Essential Elements of a Christian Worldview. Biblical Bioethics Advisor. 8:1, Spring.

Brill, Earl H. 1979. The Christian Moral Vision. New York, New York: Seabury.

Budzisewski, J. 2003. Off to College: Can We Keep Them? In Is Your Church Ready? Motivating Leaders to Live an Apologetic Life, Ravi Zacharias and Norman Geisler eds. Grand Rapids, Michigan: Zondervan.

Cameron, Nigel M. de S., Scott E. Daniels and Barbara J. White, eds. 2000. Bioengagement; Making a Christian Difference through Bioethics Today. Grand Rapids, Michigan: Eerdmans.

Cameron, Nigel M. de S. 2000. The New Medicine and the Education of the Christian Mind. In Bioengagment: Making a Christian Difference through Bioethics Today, Nigel M. de S. Cameron, Scott E. Daniels, and Barbara J. White. eds. Grand Rapids, Michigan: Eerdmans.

2001. The New Medicine: Life and Death after Hippocrates, Chicago, Illinois: Bioethics Press.

Carson, D. A. 1996. The Gagging of God: Christianity Confronts Religious Pluralism. Grand Rapids, Michigan: Zondervan.

Childs, James M. 1992. Faith, Formation, and Decision: Ethics in the Community of Promise. Minneapolis, Minnesota: Fortress Press. 
Colson, Charles, and Nancy Pearcey. 1999. How Now Shall We Live? Wheaton, Illinois: Tyndale House.

Drane, James F. n.d.a The James F. Drane Bioethics Institutue: Background and Purpose. Accessed 5 June 2007. Available from http://webs.edinboro.edu/bioethics/bkgrndpurp.asp; Internet.

Dunlop, John T. 2004. "Successful Aging: Living the End of Life to the Glory of God." Accessed 19 December 2004. Available from http://www.cbhd.org/resources/endoflife/dunlop_2001-01-05.htm; Internet.

Dyck, Arthur J. 2002 Life's Worth; The Case Against Assisted Suicide. Grand Rapids, Michigan: Eerdmans,

Erickson, Millard J. 1990. Christian Theology. Grand Rapids, Michigan: Baker Book House.

Eyer, Richard C. 1995. Pastoral Care under the Cross: God in the Midst of Suffering. St. Louis, Missouri: Concordia Publishing House.

. 1998. A Course Teaching Biblical Narrative Ethics Applied to Bioethics at a Christian University. Doctor of Ministry Thesis, Trinity International University. . 2000. Holy People Holy Lives: Law and Gospel in Bioethics. St. Louis, Missouri: Concordia Publishing House.

Feinberg, John S. and Paul D. Feinberg. 1993. Ethics for a Brave New World. Wheaton, Illinois: Crossway Books.

Focus on the Family. 2002. Life is Sacred. Produced by Manitou Motion Pictures. 7 min. Focus on the Family Films. Videocassette.

Fukayama, Francis. 2002. Our Posthuman Future: Consequences of the Biotechnology Revolution. New York, New York: Picador.

Grenz, Stanley J. 1997. The Moral Quest: Foundations of Christian Ethics. Downers Grove, Illinois: IVP.

Hardwig, John. 2000. Is There a Duty to Die? In Contemporary Moral Issues: Diversity and Consensus. 2d ed., Lawrence M. Hinman, ed. Upper Saddle River, New Jersey: Prentice Hall.

Hauerwas, Stanley. 1981. A Community of Character: Toward a Constructive Christian Social Ethic. Notre Dame: University of Notre Dame Press. 
Hayes, Robert. 1993. Cited by Andrew Kimbrell in The Human Body Shop: The Engineering and Marketing of Life. San Francisco, California: Harper San Francisco.

Hippocrates, The Oath. Tr. Frances Adams, Hippocratic writings, The Great Books, Univ. of Chicago, 1952 Encyclopedia Britannica, William Benton, publishing, xii.

Hoekema, Anthony. 1986. Created in God's Image. Grand Rapids, Michigan: Eerdmans.

Hollinger, Dennis. 2000. Sexual Ethics and Reproductive Technologies. In The Reproductive Revolution: A Christian Appraisal of Sexuality, Reproductive Technologies and the Family. John F. Kilner, Paige C. Cunningham, and W. David Hager, eds. Grand Rapids, Michigan: Eerdmans.

Humphry, Derek. 1991. Final Exit: The Practicalities of Self-Deliverance and assisted Suicide for the Dying. Eugene, Oregon: The Hemlock Society,

Irving, Diane Nutwell. 1999. When Does Human Life Begin? "Scientific" Myths and Scientific Facts. International Journal of Sociology and Social Policy. 19:3/4:22-36.

Imrenyi, Tibor. 2005. Sin and Bioethics. Christian Bioethics. 11:133-145.

James, Kay Coles. 1995. Transforming America from the Inside Out. Grand Rapids, Michigan: Zondervan.

James, Steven. 2006. Story: Recapture the Mystery. Grand Rapids, Michigan: Revell.

Kass, Leon. 2002. Life, Liberty and the Defense of Dignity: The Challenge for Bioethics. San Francisco, California: Encounter Books.

Kilner, John F. 1992. Life on the Line: Ethics, Aging, Ending Patients Lives, and Allocating Resources, Grand Rapids, Michigan: Eerdmans, . 2003. "Human Dignity." Paper Presented at the Center for Bioethics and Human Dignity Conference, Remaking Humanity? 17 July

Kilner, John F. and C. Ben Mitchell. 2003. Does God Need Our Help? Cloning, Assisted Suicide, \& Other Challenges in Bioethics. Wheaton, Illinois: Tyndale.

Kingsbury, Robert J. and Howard M. Ducharme "The Debate Over Total/Terminal/Palliative Sedation." Accessed 19 December 2004. Available from http://www.cbhd.org/resources/endoflife/kingsbury-ducharme_2002-01-04.htm; Internet. 
Koop, C. Everett and Timothy Johnson. 1992. Let's Talk: An Honest Conversation on Critical Issues.” Grand Rapids, Michigan: Zondervan.

Lammers Stephen and Allen Verhey eds. 1998. On Moral Medicine: Theological Perspectives in Medical Ethics 2d ed. Grand Rapids, Michigan: Eerdmans.

Lewis, C. S. 1955. The Abolition of Man: How Education Develops Man's Sense of Morality. New York, New York: Macmillan.

Lausanne Committee for World Evangelization. 2005. "Bioethics: Obstacle or Opportunity for the Gospel?" Lausanne Occasional Paper (LOP) No. 58, 2005.

Lyotard, Jean-Francois. 1979. "Introduction: The Postmodern Condition; A Report on Knowledge." Accessed 21 August, 2007. Available from http://www.idehist.uu.se/distans/ilmh/pm/lyotard-introd.htm; Internet.

McKibben, Bill. 2003. Enough: Staying Human in an Engineered Age. New York, New York: Henry Holt and Company.

Mitchell, Basil. 1990. The Christian Conscience. In The Oxford Illustrated Encyclopedia of Christianity” John McManners, ed. Oxford: Oxford University Press.

Mitchell, C. Ben. 1995. Bioethics and the Church. Bioethics and the Future of Medicine. John F. Kilner et al. eds. Grand Rapids, Michigan: Eerdmans. 2004. “Oregon's Lethal Experiment: An Annual Report.” Accessed 20 December 2004. Available from http://www.cbhd.org/resources/endoflife/mitchell_2001-02-22.htm; Internet.

Mitchell, C. Ben., Edmund D. Pellegrino, Jean Bethke Elshtain, John F. Kilner, and Scott B. Rae. 2007. Biotechnology and the Human Good. Washington, D.C.: Georgetown University Press.

Newbigin, Leslie. 1989. The Gospel in a Pluralist Society. Grand Rapids, Michigan: Eerdmans.

Orr, Robert D., David Schliedermayer, and David B. Biebel. 1990. Life \& Death Decisions. Colorado Springs, Colorado: Navpress.

Planned Parenthood Federation of America. 1985. "Nine Reasons Why Abortions Are Legal.” Catherine Dexter McCormick Library. Accessed 17 August 2007. Available from http://www.plannedparenthood.org/issues-action/abortion/abortion-around-theworld/reports/nine-reasons-6141.htm; Internet. 
Rae, Scott. 1999. “Autonomy and Community in Biblical Perspective.” Accessed 26 February 2007. Available from http://www.cbhd.org/resources/bioethics/rae_spring1999.htm; Internet.

Rasmusson, Arne. n.d. Ecclesiology and Ethics: The Difficulties of Ecclesial Moral Reflection. Ecclesial Review. 180-194.

Schaeffer, Francis. A. 1982. The Complete Works of Francis A. Schaeffer: A Christian Worldview. Vol. 5, A Christian View of the West. 2d ed. Westchester, Illinois: Crossway Books.

Schmidt, Alvin J. 2001. Under the Influence: How Christianity Transformed Civilization. Grand Rapids, Michigan: Zondervan.

Sire, James W. 2004. Naming the Elephant: Worldview as a Concept. Downers Grove, Illionois: IVP.

Simmons, Paul D. 1996. Biblical Authority and the Not-So-Strange Silence of Scripture on Abortion. Christian Bioethics 2. 1:66-82.

Singer, Peter. 2004. The President of Good \& Evil: The Ethics of George W. Bush. New York, New York: Dutton.

2005. "The Sanctity of Human Life, Here Today, Gone Tomorrow." Accessed 10 September 2005. Available from http://www.foreignpolicy.com/story/cms.php?story_id=3159\&fpsrc=ealert050906; Internet.

Smith, Wesley, J. 2000. Culture of Death: The Assault on Medical Ethics in America San Francisco, California: Encounter Books.

Song, Robert. 2005. Christian Bioethics and the Church's Political Worship. Christian Bioethics 11, 333-348.

Staasen, Glenn H. and David P. Gushee. 2003. Kingdom Ethics: Following Jesus in Contemporary Context. Downers Grove, Illinois: IVP.

Stewart, Gary P., William R. Cutrer, Timothy J. Denny, Donal P. O’Mathuna, Paige C. Cunningham, John F. Kilner, and Linda K. Bevington. 1998. Basic Questions on Suicide and Euthanasia: Are They Ever Right? Grand Rapids, Michigan: Kregel. 
Stewart, Gary P., William R. Cutrer, Timothy J. Denny, Donal P. O’Mathuna, Paige C. Cunningham, John F. Kilner, and Linda K. Bevington. 1998. Basic Questions on End of Life Decisions: How Do We Know What's Right? Grand Rapids, Michigan: Kregel.

Stott, John R. W. 1999. Human Rights and Human Wrongs: Major Issues for a New Century. Grand Rapids, Michigan: Baker.

. 2006. Issues Facing Christians Today. $4^{\text {th }}$ ed. Grand Rapids, Michigan: Zondervan.

Streatfield, G. S. n.d.a. The Self-Interpretation of Jesus Christ: A Study of the Messianic Consciousness as Reflected in the Synoptics. New York, New York: Eaton and Mains.

Verhey, Allen. 2002. Remembering Jesus: Christian Community, Scripture and the Moral Life. Grand Rapids, Michigan: Eerdmans.

. 2003. Reading the Bible in the Strange World of Medicine. Grand Rapids, Michigan: Eerdmans

Wenham, Gordon J. 2000. Story as Torah: Reading Old Testament Narrative Ethically. Grand Rapids, Michigan: Baker Academic.

Wheeler, Sondra Ely. 1996. Stewards of Life: Bioethics and Pastoral Care. Nashville, Tennessee: Abingdon Press. 